Supporting Information

\title{
Enantioenriched BCP Benzylamine Synthesis via Metal Hydride Hydrogen Atom Transfer/Sulfinimine Addition to [1.1.1]Propellane
}

\author{
Russell Shelp, ${ }^{a}$ Rohan R. Merchant, ${ }^{b}$ Jonathan M. E. Hughes, ${ }^{\mathrm{c}}$ and Patrick J. Walsh ${ }^{\mathrm{a}}$ \\ rohan.merchant@merck.com jonathan.hughes@merck.com pwalsh@sas.upenn.edu
}

${ }^{a}$ Department of Chemistry, Roy and Diana Vagelos Laboratories, Penn/Merck Laboratory for HighThroughput Experimentation, University of Pennsylvania, 231 South 34th Street, Philadelphia, Pennsylvania 19104, United States

${ }^{\mathrm{b}}$ Department of Discovery Chemistry, Merck \& Co., Inc., South San Francisco, California 94080, United States

${ }^{c}$ Department of Process Research and Development, Merck \& Co., Inc., Rahway, New Jersey 07065 , United States

Table of Contents

1. General considerations and preparation of starting material ....................S2-S7

2. General procedure for MH HAT reaction and product characterization..............S7-S16

3. Optimization and procedure for larger scale MH HAT ..........................S16-S17

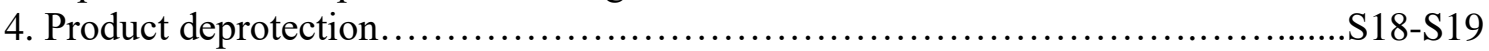

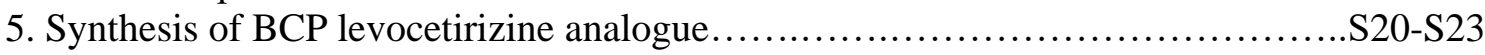

6. Attempted optimization of MH HAT to electron-rich substrates....................S24

7. Propellylation of heterocyclic substrates via 2-azaallyl anion chemistry..............S25

8. NMR spectra for mechanistic experiments.................................... 226

9. GC-MS chromatograms to monitor silane distribution during a reaction............S29-S33

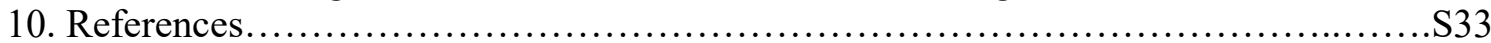

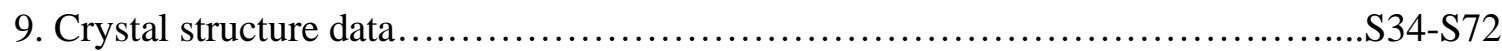

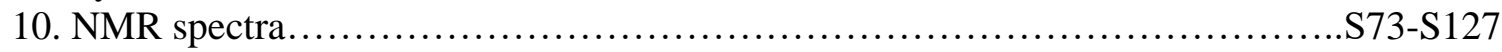


General Methods: All reactions were conducted under a nitrogen atmosphere in a glovebox with oven-dried glassware and standard Schlenk or vacuum line techniques unless otherwise noted. All solutions were handled under nitrogen and transferred via an Eppendorf brand pipetter, or handled under an inert atmosphere using syringes/needles and standard Schlenk techniques. Anhydrous solvents were purchased from Sigma-Aldrich and directly used. Unless otherwise stated, reagents were commercially available and used as purchased. Chemicals were purchased from Sigma-Aldrich, Acros, or Alfa Aesar and solvents were purchased from Fisher Scientific. $\mathrm{Mn}(\mathrm{dpm})_{3}$ was purchased from Strem Chemical. $\mathrm{Ph}(\mathrm{OiPr}) \mathrm{SiH}_{2}$ was synthesized using $\mathrm{PhSiH}_{3}$ purchased from Acros. iPrOH solvent used for $\mathrm{Ph}(\mathrm{OiPr}) \mathrm{SiH}_{2}$ synthesis and MH HAT reactions was HPLC grade (purchased from Fisher) and was sparged with nitrogen then stored over molecular sieves under nitrogen atmosphere in a glovebox. Reaction progress was monitored by thin-layer chromatography using glass-backed Silica Gel HL TLC Plates purchased from Sorbent Technologies and visualized by short-wave ultraviolet light. Reactions were performed in 4 or $20 \mathrm{~mL}$ vials purchased from Chemglass Life Sciences. Flash chromatography was performed with silica gel (300-400 mesh, Silicycle) when $\mathrm{SiO}_{2}$ as the stationary phase is indicated. ${ }^{1} \mathrm{H}$ and ${ }^{13} \mathrm{C}\left\{{ }^{1} \mathrm{H}\right\}$ NMR spectra were obtained using a Brüker AM500 Fourier-transform NMR spectrometer at 500 and 125, 600 and 150, or 400 and $100 \mathrm{MHz}$, respectively. Chemical shifts were reported in units of parts per million (ppm) downfield from tetramethylsilane (TMS), and all coupling constants were reported in hertz. High resolution mass spectrometry (HRMS) data were obtained on a Waters LC-TOF mass spectrometer (model LCTXE Premier) using chemical ionization (CI) or electrospray ionization (ESI) in positive or negative mode, depending on the analyte. SFC analysis was performed on an Agilent 1260 Infinity instrument using the indicated column, eluent conditions, and the specified wavelength. GC-MS data for the silane monitoring mechanistic experiments were recorded on an Agilent 7890A/5977A gas chromatograph/mass selective detection system using the indicated temperature and gradient conditions. X-ray intensity data were collected on a Rigaku XtaLAB Synergy-S diffractometer equipped with an HPC area detector (Dectris Pilatus3 R 200K) and employing confocal multilayer optic-monochromated Mo-K $\alpha$ radiation $(\lambda=0.71073 \AA)$ at a temperature of $100 \mathrm{~K}$. Rotation frames were integrated using SAINT10 or CrysAlisPro1 1 producing a listing of unaveraged $\mathrm{F} 2$ and $\sigma(\mathrm{F} 2)$ values. The intensity data were corrected for Lorentz and polarization effects and for absorption using SADABS12 or SCALE3 ABSPACK.

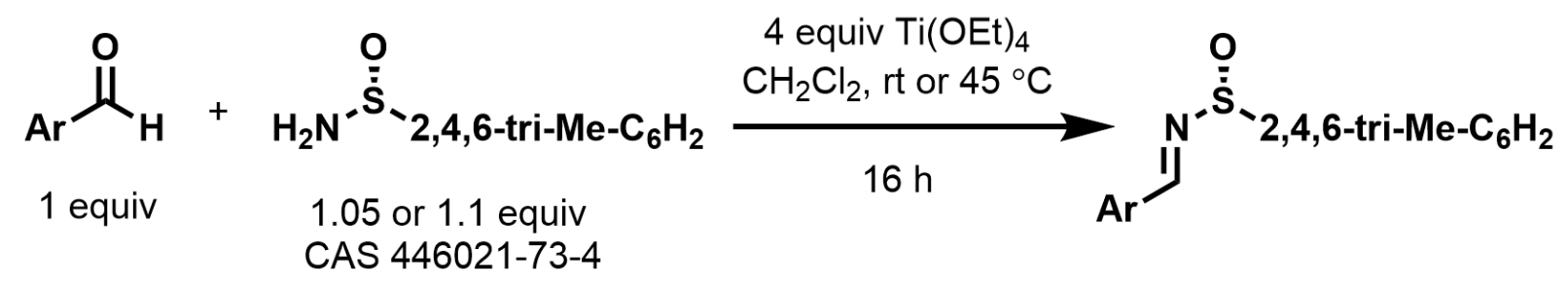

General Procedure A (starting material synthesis): To an oven-dried vial charged with a stir bar, aldehyde (1 equiv, $0.4 \mathrm{mmol}$ ) and 2,4,6-trimethylbenzenesulfinamide (1.05 or 1.1 equiv, 
0.42 or $0.44 \mathrm{mmol})$ were added. Dichloromethane $(8 \mathrm{~mL}, 0.05 \mathrm{M})$ followed by Ti(OEt $)_{4}(4$ equiv, $0.34 \mathrm{~mL}$ neat) wee added under a nitrogen atmosphere in a glovebox, the vial was capped, and then removed from the box to stir on a stir plate. The reaction was stirred for $16 \mathrm{~h}$ at room temperature if the aldehydic substrate contains an acid-sensitive functional group (e.g. ester), or at $45^{\circ} \mathrm{C}$ if it did not. At the end of the reaction period, several drops of saturated $\mathrm{NaHCO}_{3}$ aqueous solution were added to precipitate the titanium salts. The mixture was then filtered over a fritted funnel, washing the pad of titanium salts with an equivalent volume of $\mathrm{CH}_{2} \mathrm{Cl}_{2}$. The organic solvent was then concentrated under reduced pressure. The sulfinimine was purified in one of two ways: [1] dissolving in $\mathrm{CH}_{2} \mathrm{Cl}_{2}$ and filtering over a short pad of $\mathrm{SiO}_{2}$, which was sufficient to remove excess mesityl sulfinamide and rapidly elutes the sulfinimine product, or [2] column chromatography on $\mathrm{SiO}_{2}$ eluting with EtOAc/hexanes if some aldehyde SM remained due to incomplete conversion (sulfinimine products are more polar than the corresponding aldehyde starting materials, which elute first on $\mathrm{SiO}_{2}$ ).

Starting materials shown below are new compounds. All other starting materials were prepared according to the literature procedures ${ }^{1-2}$ and spectral data matched previous reports.

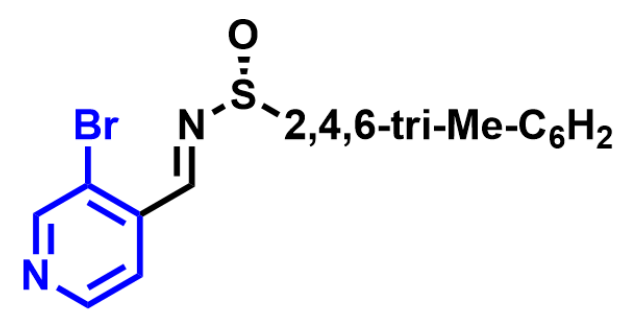

\section{1-(3-bromopyridin-4-yl)- $N$-(mesityl $\left(\hat{\kappa}^{1}\right.$-oxidaneyl)- $\kappa^{3}$-sulfaneyl)methanimine (4i)}

Prepared according to General Procedure A on a $0.3 \mathrm{mmol}$ scale. The product was obtained as a yellow solid, $73.9 \mathrm{mg}, 70 \%$.

${ }^{1} \mathrm{H}$ NMR $\left(400 \mathrm{MHz}, \mathrm{CDCl}_{3}\right): \delta 9.18(\mathrm{~s}, 1 \mathrm{H}), 8.96(\mathrm{~s}, 1 \mathrm{H}), 8.58(\mathrm{~d}, J=4.9 \mathrm{~Hz}, 1 \mathrm{H}), 7.81(\mathrm{~d}, J=$ $4.9 \mathrm{~Hz}, 1 \mathrm{H}), 6.98(\mathrm{~s}, 2 \mathrm{H}), 2.50(\mathrm{~s}, 6 \mathrm{H}), 2.29(\mathrm{~s}, 3 \mathrm{H}) \mathrm{ppm}$.

${ }^{13} \mathrm{C}\left\{{ }^{1} \mathrm{H}\right\}$ NMR $\left(100 \mathrm{MHz}, \mathrm{CDCl}_{3}\right): \delta 159.0,153.3,148.7,142.3,139.3,138.6,134.2,131.1$, $122.8,21.2,18.9$ ppm.*

HRMS calc'd for $\left[\mathrm{C}_{15} \mathrm{H}_{15} \mathrm{BrN}_{2} \mathrm{OS}+\mathrm{H}\right]^{+}=351.0167$, found 351.0146 .

*One aromatic signal was not observed due to coincidental overlap of two resonances.

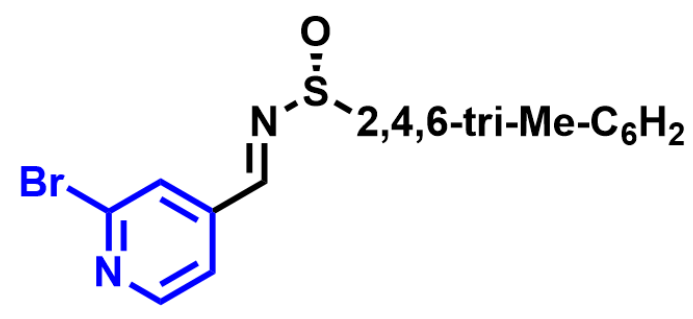




\section{(1-(2-bromopyridin-4-yl)- $N$-(mesityl $\left(\hat{\kappa}^{1}\right.$-oxidaneyl)- $\hat{K}^{3}$-sulfaneyl)methanimine $(4 \mathbf{j})$}

Prepared according to General Procedure A on 0.4 mmol scale. Following workup, the reaction mixture was purified by method 1 to obtain a yellow solid, $127.4 \mathrm{mg}, 91 \%$.

${ }^{1} \mathrm{H}$ NMR (400 MHz, $\left.\mathrm{CDCl}_{3}\right): \delta 8.75(\mathrm{~s}, 1 \mathrm{H}), 8.50(\mathrm{~d}, J=5.0 \mathrm{~Hz}, 1 \mathrm{H}), 7.89(\mathrm{~s}, 1 \mathrm{H}), 7.63(\mathrm{dd}, J=$ $5.2,1.3 \mathrm{~Hz}, 1 \mathrm{H}), 6.89$ (s, 2H), $2.48(\mathrm{~s}, 6 \mathrm{H}), 2.30(\mathrm{~s}, 3 \mathrm{H}) \mathrm{ppm}$.

${ }^{13} \mathrm{C}\left\{{ }^{1} \mathrm{H}\right\}$ NMR $\left(100 \mathrm{MHz}, \mathrm{CDCl}_{3}\right): \delta 158.3,151.2,143.3,142.7,142.4,138.6,134.2,131.2$, $127.0,121.8,21.2,19.0 \mathrm{ppm}$.

HRMS calc'd for $\left[\mathrm{C}_{15} \mathrm{H}_{15} \mathrm{BrN}_{2} \mathrm{OS}+\mathrm{H}\right]^{+}=351.0167$, found 351.0182 .

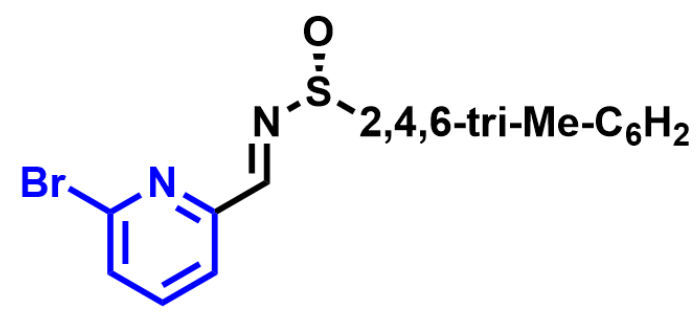

\section{1-(6-bromopyridin-2-yl)- $N$-(mesityl $\left(\hat{K}^{1}\right.$-oxidaneyl)- $\hat{K}^{3}$-sulfaneyl)methanimine (4k)}

Prepared according to General Procedure A on $0.4 \mathrm{mmol}$ scale. Following workup, the reaction mixture was purified by method 2 (flash chromatography, 20\% EtOAc in hexanes on $\mathrm{SiO}_{2}$ ) to obtain a yellow solid, $114.3 \mathrm{mg}, 81 \%$.

${ }^{1} \mathrm{H}$ NMR (400 MHz, $\left.\mathrm{CDCl}_{3}\right): \delta 8.87(\mathrm{~s}, 1 \mathrm{H}), 7.98(\mathrm{dd}, J=7.4,0.9 \mathrm{~Hz}, 1 \mathrm{H}), 7.63(\mathrm{t}, J=7.6 \mathrm{~Hz}$, $1 \mathrm{H}), 7.58(\mathrm{dd}, J=7.6,0.9 \mathrm{~Hz}, 1 \mathrm{H}), 6.87(\mathrm{~s}, 2 \mathrm{H}), 2.50(\mathrm{~s}, 6 \mathrm{H}), 2.29(\mathrm{~s}, 3 \mathrm{H}) \mathrm{ppm}$.

${ }^{13} \mathrm{C}\left\{{ }^{1} \mathrm{H}\right\}$ NMR $\left(100 \mathrm{MHz}, \mathrm{CDCl}_{3}\right): \delta 161.0,153.5,142.3,142.1,139.0,138.7,134.7,131.0$, $130.6,121.9,21.2,19.0 \mathrm{ppm}$.

HRMS calc'd for $\left[\mathrm{C}_{15} \mathrm{H}_{15} \mathrm{BrN}_{2} \mathrm{OS}+\mathrm{Na}\right]^{+}=372.9986$, found 372.9999 .

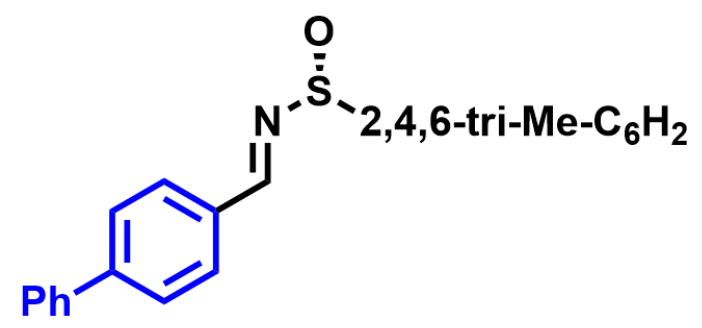

\section{1-([1,1'-biphenyl]-4-yl)- $N$-(mesityl $\left(\kappa^{1}\right.$-oxidaneyl)- $\hat{K}^{3}$-sulfaneyl)methanimine (4b)}

Prepared according to General Procedure A on 0.4 mmol scale. Following workup, the reaction mixture was purified by method 2 (flash chromatography, $15 \rightarrow 25 \%$ EtOAc in hexanes on $\mathrm{SiO}_{2}$ ) to obtain a white solid, $82.6 \mathrm{mg}, 59 \%$. 
${ }^{1} \mathrm{H}$ NMR $\left(400 \mathrm{MHz}, \mathrm{CDCl}_{3}\right): \delta 8.89(\mathrm{~s}, 1 \mathrm{H}), 7.93(\mathrm{~d}, J=8.3 \mathrm{~Hz}, 1 \mathrm{H}), 7.69(\mathrm{~d}, J=8.3 \mathrm{~Hz}, 2 \mathrm{H})$, 7.64-7.61 (m, 2H), 7.49-7.45 (m, 2H), $7.40(\mathrm{tt}, J=7.3,1.0 \mathrm{~Hz}, 1 \mathrm{H}), 6.88(\mathrm{~s}, 2 \mathrm{H}) 2.54(\mathrm{~s}, 6 \mathrm{H})$, $2.30(\mathrm{~s}, 3 \mathrm{H}) \mathrm{ppm}$.

${ }^{13} \mathrm{C}\left\{{ }^{1} \mathrm{H}\right\}$ NMR $\left(100 \mathrm{MHz}, \mathrm{CDCl}_{3}\right): \delta 161.2,145.3,141.7,140.0,138.5,135.5,132.9,130.9$, $130.1,129.0,128.2,127.6,127.3,21.2,19.0 \mathrm{ppm}$.

HRMS calc'd for $\left[\mathrm{C}_{22} \mathrm{H}_{21} \mathrm{NOS}+\mathrm{H}\right]^{+}=348.1422$, found 348.1440 .

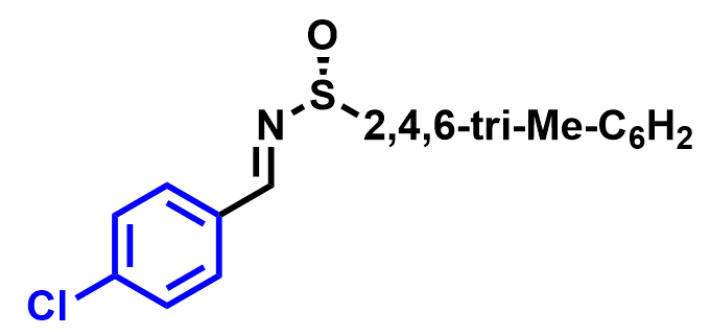

\section{1-(4-chlorophenyl)- $N$-(mesityl( $\kappa^{1}$-oxidaneyl)- $\kappa^{3}$-sulfaneyl)methanimine (4d)}

Prepared according to General Procedure A on $0.4 \mathrm{mmol}$ scale. Following workup, the reaction mixture was purified by method 2 (flash chromatography, $15 \rightarrow 40 \%$ EtOAc in hexanes on $\mathrm{SiO}_{2}$ ) to obtain a white solid, $93.9 \mathrm{mg}, 77 \%$.

${ }^{1} \mathrm{H}$ NMR (400 MHz, $\left.\mathrm{CDCl}_{3}\right): \delta 8.79(\mathrm{~s}, 1 \mathrm{H}), 7.78(\mathrm{~d}, J=8.5 \mathrm{~Hz}, 2 \mathrm{H}), 7.43(\mathrm{~d}, J=8.5 \mathrm{~Hz}, 2 \mathrm{H})$, $6.86(\mathrm{~s}, 2 \mathrm{H}), 2.49(\mathrm{~s}, 6 \mathrm{H}), 2.28(\mathrm{~s}, 3 \mathrm{H}) \mathrm{ppm}$.

${ }^{13} \mathrm{C}\left\{{ }^{1} \mathrm{H}\right\}$ NMR $\left(100 \mathrm{MHz}, \mathrm{CDCl}_{3}\right): \delta 160.3,141.9,138.7,138.5,135.2,132.4,130.9,130.7$, $129.3,21.2,18.9 \mathrm{ppm}$.

HRMS calc'd for $\left[\mathrm{C}_{16} \mathrm{H}_{16} \mathrm{ClNOS}+\mathrm{H}\right]^{+}=306.0719$, found 306.0711 .

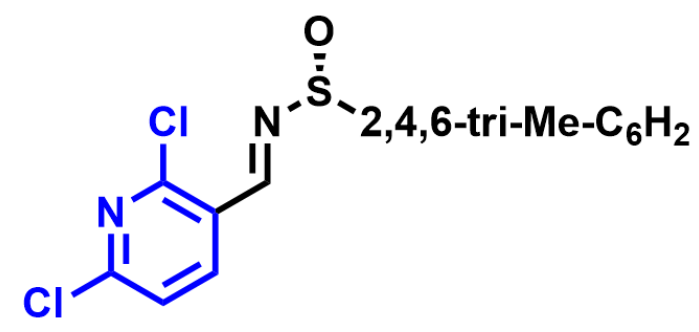

\section{(1-(2,6-dichloropyridin-3-yl)- $N$-(mesityl $\left(\kappa^{1}\right.$-oxidaneyl)- $\kappa^{3}$-sulfaneyl)methanimine (4m)}

Prepared according to General Procedure A on $0.4 \mathrm{mmol}$ scale. Following workup, the reaction mixture was purified by method 2 (flash chromatography, 20\% EtOAc in hexanes on $\mathrm{SiO}_{2}$ ) to obtain a white solid, $100.0 \mathrm{mg}, 73 \%$.

${ }^{1} \mathrm{H}$ NMR $\left(400 \mathrm{MHz}, \mathrm{CDCl}_{3}\right): \delta 9.17(\mathrm{~s}, 1 \mathrm{H}), 8.29(\mathrm{~d}, J=8.2 \mathrm{~Hz}, 1 \mathrm{H}), 7.33(\mathrm{~d}, J=8.0 \mathrm{~Hz}, 1 \mathrm{H})$, $6.88(\mathrm{~s}, 2 \mathrm{H}), 2.49$ (s, 6H), 2.29 (s, 3H) ppm. 
${ }^{13} \mathrm{C}\left\{{ }^{1} \mathrm{H}\right\}$ NMR $\left(100 \mathrm{MHz}, \mathrm{CDCl}_{3}\right): \delta 156.4,153.5,151.5,142.3,140.2,138.6,134.5,131.1$, $127.1,123.8,21.2,18.9 \mathrm{ppm}$.

HRMS calc'd for $\left[\mathrm{C}_{15} \mathrm{H}_{14} \mathrm{Cl}_{2} \mathrm{~N}_{2} \mathrm{OS}+\mathrm{H}\right]^{+}=341.0282$, found 341.0263 .<smiles></smiles>

$N$-(mesityl( $\boldsymbol{\kappa}^{1}$-oxidaneyl)- $\hat{\kappa}^{3}$-sulfaneyl)-1-(6-methoxypyridin-2-yl)methanimine (4l)

Prepared according to General Procedure A on $0.4 \mathrm{mmol}$ scale. Following workup, the reaction mixture was purified by method 1 to obtain a clear, colorless oil, $113.6 \mathrm{mg}, 92 \%$.

${ }^{1} \mathrm{H}$ NMR (400 MHz, $\left.\mathrm{CDCl}_{3}\right): \delta 8.82(\mathrm{~s}, 1 \mathrm{H}), 7.65-7.59(\mathrm{~m}, 2 \mathrm{H}), 6.87$ (s, 2H), 6.84 (dd, $J=7.3$, $1.6 \mathrm{~Hz}, 1 \mathrm{H}), 3.99$ (s, 3H), 2.51 (s, 6H), 2.29 (s, 3H) ppm.

${ }^{13} \mathrm{C}\left\{{ }^{1} \mathrm{H}\right\}$ NMR $\left(100 \mathrm{MHz}, \mathrm{CDCl}_{3}\right): \delta 164.2,162.6,150.0,141.9,138.9,138.6,135.1,130.9$, $116.4,114.0,53.7,21.2,19.0 \mathrm{ppm}$.

HRMS calc'd for $\left[\mathrm{C}_{16} \mathrm{H}_{18} \mathrm{~N}_{2} \mathrm{O}_{2} \mathrm{~S}+\mathrm{Na}\right]^{+}=325.0987$, found 325.0971.<smiles>C[14CH2]c1ccccc1</smiles>

1-(3,5-bis(trifluoromethyl)phenyl)- $N$-(mesityl $\left(\hat{\Lambda}^{1}\right.$-oxidaneyl)- $\kappa^{3}$-sulfaneyl)methanimine (4e)

Prepared according to General Procedure A on $0.4 \mathrm{mmol}$ scale. Following workup, the reaction mixture was purified by method 2 (flash chromatography, 20\% EtOAc in hexanes on $\mathrm{SiO}_{2}$ ) to obtain a white solid, $144.6 \mathrm{mg}, 87 \%$.

${ }^{1} \mathrm{H} \mathrm{NMR}\left(400 \mathrm{MHz}, \mathrm{CDCl}_{3}\right): \delta 8.93(\mathrm{~s}, 1 \mathrm{H}), 8.32$ (s, 2H), 8.01 (s, 1H), $6.90(\mathrm{~s}, 2 \mathrm{H}), 2.52$ (s, 6H), $2.30(\mathrm{~s}, 3 \mathrm{H}) \mathrm{ppm}$.

${ }^{13} \mathrm{C}\left\{{ }^{1} \mathrm{H}\right\}$ NMR (100 MHz, $\left.\mathrm{CDCl}_{3}\right): \delta 158.6,142.3,138.6,135.7,134.4,132.7\left(\mathrm{q}, J_{\mathrm{C}-\mathrm{F}}=34 \mathrm{~Hz}\right)$, $131.1,129.27,125.5$ (heptet, $\left.J_{\mathrm{C}-\mathrm{F}}=3.6 \mathrm{~Hz}\right), 123.0\left(\mathrm{q}, J_{\mathrm{C}-\mathrm{F}}=273 \mathrm{~Hz}\right), 21.1,18.9 \mathrm{ppm}$.

HRMS calc'd for $\left[\mathrm{C}_{18} \mathrm{H}_{15} \mathrm{~F}_{6} \mathrm{NOS}+\mathrm{H}\right]^{+}=408.0857$, found 408.0842 . 


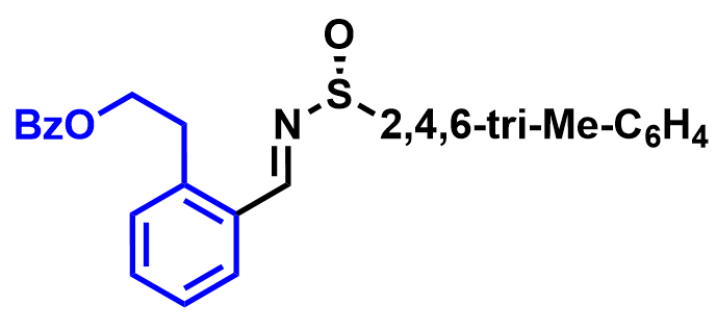

\section{2-(((mesitylsulfinyl)imino)methyl)phenethyl benzoate (4o)}

To a $100 \mathrm{~mL}$ RBF under a nitrogen atmosphere charged with a stir bar, was added aldehyde (293.9 mg, $1.16 \mathrm{mmol}, 1$ equiv), 2,4,6-trimethylbenzenesulfinamide (222.6 mg, $1.21 \mathrm{mmol}, 1.05$ equiv), and THF (23 mL). The flask was chilled in an ice bath. Ti(OEt) $)_{4}(0.93 \mathrm{~mL}, 4.64 \mathrm{mmol}, 4$ equiv) was added via syringe to the chilled solution, dropwise, over approximately 5 minutes. The flask was then warmed to room temperature and stirred $18 \mathrm{~h}$, at which point the solution had changed from colorless to yellow. The mixture was precipitated with saturated $\mathrm{NaHCO}_{3}$ solution, filtered over a fritted funnel, and washed with an equivalent reaction volume of $\mathrm{CH}_{2} \mathrm{Cl}_{2}$. Flash chromatography $(15 \rightarrow 40 \%$ EtOAc in hexanes) gave the product as a yellow solid, $253.4 \mathrm{mg}$, $52 \%$.

${ }^{1} \mathrm{H}$ NMR (400 MHz, $\left.\mathrm{CDCl}_{3}\right): \delta 9.14(\mathrm{~s}, 1 \mathrm{H}), 7.97-7.95(\mathrm{~m}, 2 \mathrm{H}), 7.92-7.90(\mathrm{~m}, 1 \mathrm{H}), 7.55(\mathrm{tt}, J=$ 7.4, 1.2 Hz, 1H), 7.46-7.40 (m, 3H), 7.37-7.33 (m, 2H), $6.82(\mathrm{~s}, 2 \mathrm{H}), 4.53-4.41(\mathrm{~m}, 2 \mathrm{H}), 3.55-$ $3.32(\mathrm{~m}, 2 \mathrm{H}), 2.50(\mathrm{~s}, 6 \mathrm{H}), 2.26(\mathrm{~s}, 3 \mathrm{H}) \mathrm{ppm}$.

${ }^{13} \mathrm{C}\left\{{ }^{1} \mathrm{H}\right\}$ NMR $\left(100 \mathrm{MHz}, \mathrm{CDCl}_{3}\right): \delta 166.4,160.1,141.7,139.3,138.3,135.4,133.0,132.3$, $131.5,131.0,130.8,130.2,129.7,128.4,127.5,65.1,32.4,21.2,19.0$ ppm.*

HRMS calc'd for $\left[\mathrm{C}_{25} \mathrm{H}_{25} \mathrm{NO}_{3} \mathrm{~S}+\mathrm{Na}\right]^{+}=442.1453$, found 442.1447 .

*One aromatic signal was not observed due to coincidental overlap of two resonances.

General Procedure B (MH HAT propellylation of imines): To a $4 \mathrm{~mL}$ vial charged with a stir bar, the sulfinimine $(0.1 \mathrm{mmol})$ is added. The vial is brought under a nitrogen atmosphere in the glovebox and charged with $\mathrm{Mn}(\mathrm{dpm})_{3}(2.4 \mathrm{mg}, 4 \mathrm{~mol} \%)$. A stock solution of [1.1.1]propellane (0.59-0.67 M, 208-237 $\mu \mathrm{L}$ ) and an equivalent volume of $\mathrm{iPrOH}$ (degassed by sparging with nitrogen and stored over molecular sieves) are added. If the substrate imine does not dissolve, $\mathrm{CH}_{2} \mathrm{Cl}_{2}$ (1-4 volumes relative to volume of [1.1.1]propellane in $\mathrm{Et}_{2} \mathrm{O}$ stock solution used) is added. The vial is capped, removed from the glovebox, and cooled to $0{ }^{\circ} \mathrm{C}$ in an ice bath. A nitrogen inlet needle is added and $\mathrm{Ph}(\mathrm{OiPr}) \mathrm{SiH}_{2}(54 \mu \mathrm{L}, 0.3 \mathrm{mmol}, 3$ equiv $)$ is added over 3-5 minutes at a rate of approximately 1 drop every 15-20 seconds. The inlet needle is removed and the flask is stirred in the ice bath for 10 minutes following completion of silane addition. Over this period, the reaction mixture gradually decolorizes from dark brown and opaque to light orange or light yellow. The vial is removed from the ice bath and stirred at ambient temperature 
for $48 \mathrm{~h}$. At the end of the reaction period, the reaction mixture is uncapped and poured into a separatory funnel containing $5 \mathrm{~mL}$ saturated EDTA (ethylenediaminetetraacetic acid) solution. The flask is rinsed twice with $2 \mathrm{~mL}$ EtOAc, which is transferred to the separatory funnel. The layers are shaken, separated, and the aqueous layer again washed with $4 \mathrm{~mL}$ EtOAc. The combined organic layers are washed with $5 \mathrm{~mL}$ brine, dried over $\mathrm{MgSO}_{4}$, filtered, and concentrated under reduced pressure. The crude material is purified by flash chromatography on $\mathrm{SiO}_{2}$ to yield the product.

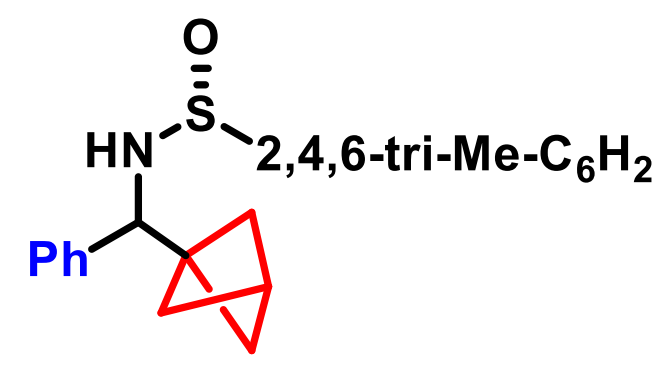

\section{$N$-(bicyclo[1.1.1]pentan-1-yl(phenyl)methyl)-2,4,6-trimethylbenzenesulfinamide (9a)}

Prepared according to General Procedure B on $0.15 \mathrm{mmol}$ scale. The product was purified by flash column chromatography on $\mathrm{SiO}_{2}(5 \rightarrow 10 \%$ EtOAc in hexanes) to obtain $36.6 \mathrm{mg}$ of a white solid, $72 \%$, as a single diastereomer (according to ${ }^{1} \mathrm{H}$ NMR analysis).

${ }^{1} \mathrm{H}$ NMR (400 MHz, $\left.\left(\mathrm{CD}_{3}\right)_{2} \mathrm{CO}\right): 7.24-7.14(\mathrm{~m}, 5 \mathrm{H}), 6.76(\mathrm{~s}, 2 \mathrm{H}), 5.73(\mathrm{~d}, J=6.4 \mathrm{~Hz}, 1 \mathrm{H}), 4.45$ $(\mathrm{d}, J=6.6 \mathrm{~Hz}, 1 \mathrm{H}), 2.49(\mathrm{~s}, 6 \mathrm{H}), 2.45(\mathrm{~s}, 1 \mathrm{H}), 2.20(\mathrm{~s}, 3 \mathrm{H}), 1.68(\mathrm{dd}, J=9.4,1.4 \mathrm{~Hz}, 3 \mathrm{H}), 1.60$ (dd, $J=9.4,1.4 \mathrm{~Hz}, 3 \mathrm{H}) \mathrm{ppm}$.

${ }^{13} \mathrm{C}\left\{{ }^{1} \mathrm{H}\right\}$ NMR $\left(100 \mathrm{MHz}, \mathrm{CDCl}_{3}\right): \delta 142.1,140.7,138.9,137.8,131.4,128.7,127.7,127.6$, $60.3,49.4,48.9,28.5,20.9,19.8 \mathrm{ppm}$.

HRMS calc'd for $\left[\mathrm{C}_{21} \mathrm{H}_{25} \mathrm{NOS}+\mathrm{H}\right]^{+}=340.1735$, found 340.1741 .

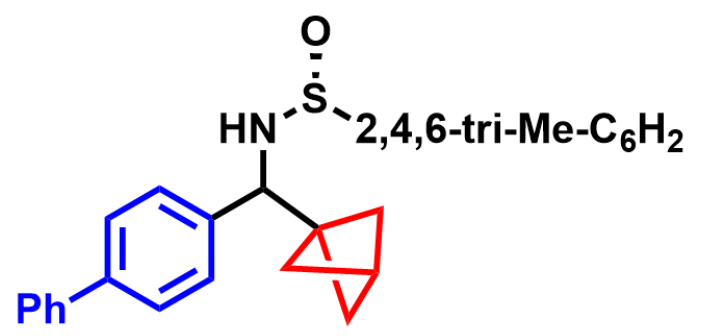

$N$-([1,1'-biphenyl]-4-yl(bicyclo[1.1.1]pentan-1-yl)methyl)-1-mesityl-1-( $\boldsymbol{\kappa}^{1}$-oxidaneyl)- $\boldsymbol{\kappa}^{\mathbf{3}}$ sulfanamine $(9 b)$

Prepared according to General Procedure $\mathrm{B}$ on $0.1 \mathrm{mmol}$ scale, adding 1 volume of $\mathrm{CH}_{2} \mathrm{Cl}_{2}$ to facilitate solubility. The product was purified by flash column chromatography on $\mathrm{SiO}_{2}(15 \rightarrow$ $25 \%$ EtOAc in hexanes eluent) to obtain $28.4 \mathrm{mg}$ of a white solid, $68 \%$, as a single diastereomer (according to ${ }^{1} \mathrm{H}$ NMR analysis). 
${ }^{1} \mathrm{H}$ NMR $\left(400 \mathrm{MHz}, \mathrm{CDCl}_{3}\right): \delta 7.56(\mathrm{~d}, J=7.6 \mathrm{~Hz}, 2 \mathrm{H}), 7.48(\mathrm{~d}, J=8.1 \mathrm{~Hz}, 2 \mathrm{H}), 7.43(\mathrm{t}, J=7.7$ $\mathrm{Hz}, 2 \mathrm{H}), 7.33(\mathrm{t}, J=7.1 \mathrm{~Hz}, 1 \mathrm{H}), 7.22(\mathrm{~d}, J=8.1 \mathrm{~Hz}, 2 \mathrm{H}), 6.79(\mathrm{~s}, 2 \mathrm{H}), 4.52(\mathrm{~d}, J=3.5 \mathrm{~Hz}, 1 \mathrm{H})$, $4.44(\mathrm{~d}, J=3.5 \mathrm{~Hz}, 1 \mathrm{H}), 2.55(\mathrm{~s}, 6 \mathrm{H}), 2.54(\mathrm{~s}, 1 \mathrm{H}), 2.24(\mathrm{~s}, 3 \mathrm{H}), 1.75(\mathrm{~d}, J=9.4 \mathrm{~Hz}, 3 \mathrm{H}), 1.69$ (d, $J=9.4 \mathrm{~Hz}, 3 \mathrm{H}) \mathrm{ppm}$.

${ }^{13} \mathrm{C}\left\{{ }^{1} \mathrm{H}\right\}$ NMR $\left(100 \mathrm{MHz}, \mathrm{CDCl}_{3}\right): \delta 140.9,140.7,140.2,139.2,137.8,136.9,130.9,128.8$, $127.4,127.3,127.1,127.0,58.3,48.9,47.4,28.3,21.1,19.7 \mathrm{ppm}$.

HRMS calc'd for $\left[\mathrm{C}_{27} \mathrm{H}_{29} \mathrm{NOS}+\mathrm{Na}\right]^{+}=438.1868$, found 438.1851 .

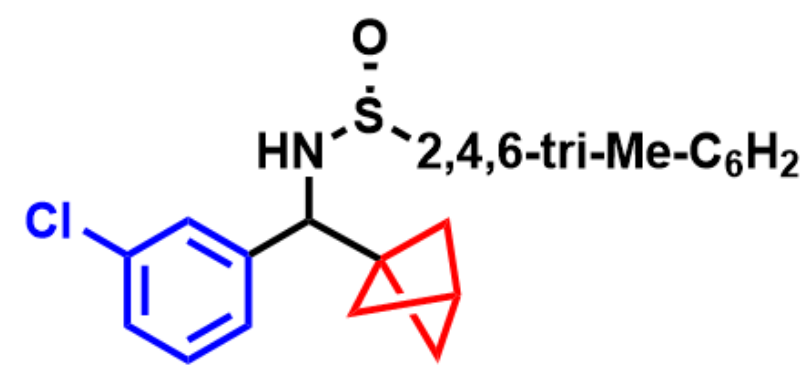

\section{$N$-(bicyclo[1.1.1]pentan-1-yl(3-chlorophenyl)methyl)-1-mesityl-1-( $\kappa^{1}$-oxidaneyl)- $\kappa^{3}$ - sulfanamine (9c)}

Prepared according to the General Procedure B. The product was purified by flash column chromatography on $\mathrm{SiO}_{2}$ (20\% EtOAc in hexanes eluent) to obtain $25.6 \mathrm{mg}$ of a white solid, $68 \%$, as a single diastereomer (according to ${ }^{1} \mathrm{H}$ NMR analysis).

${ }^{1} \mathrm{H}$ NMR (400 MHz, $\left.\mathrm{CDCl}_{3}\right): \delta$ 7.14-7.13 (m, 2H), $7.03(\mathrm{~s}, 1 \mathrm{H}), 6.99$ (td, $\left.J=4.5,1 \mathrm{~Hz}, 1 \mathrm{H}\right), 6.73$ (s, 2H), $4.46(\mathrm{~d}, J=3.6 \mathrm{~Hz}, 1 \mathrm{H}), 4.38(\mathrm{~d}, J=3.4,1 \mathrm{H}), 2.53(\mathrm{~s}, 1 \mathrm{H}), 2.52(\mathrm{~s}, 6 \mathrm{H}), 2.22(\mathrm{~s}, 3 \mathrm{H})$, $1.69(\mathrm{dd}, J=9.5,1.7 \mathrm{~Hz}, 3 \mathrm{H}), 1.63(\mathrm{dd}, J=9.5,1.7 \mathrm{~Hz}, 3 \mathrm{H}) \mathrm{ppm}$.

${ }^{13} \mathrm{C}\left\{{ }^{1} \mathrm{H}\right\}$ NMR $\left(100 \mathrm{MHz}, \mathrm{CDCl}_{3}\right): \delta 142.1,140.8,136.9,136.8,134.0,130.0,129.4,127.4$, $126.8,125.1,57.4,48.7,47.2,28.2,21.0,19.6 \mathrm{ppm}$.

HRMS calc'd for $\left[\mathrm{C}_{21} \mathrm{H}_{24} \mathrm{ClNOS}+\mathrm{H}\right]^{+}=374.1345$, found 374.1338 .

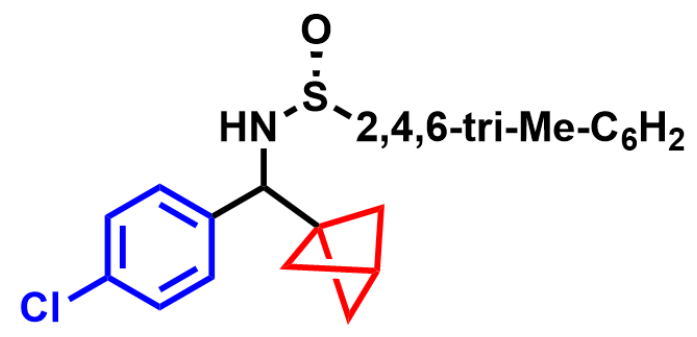

$N$-(bicyclo[1.1.1]pentan-1-yl(4-chlorophenyl)methyl)-1-mesityl-1-( $\boldsymbol{\Lambda}^{1}$-oxidaneyl)- $\boldsymbol{K}^{3}$ sulfanamine (9d) 
Prepared according to General Procedure B on $0.1 \mathrm{mmol}$ scale, adding 1 volume of $\mathrm{CH}_{2} \mathrm{Cl}_{2}$ to facilitate solubility. The product was purified by flash column chromatography on $\mathrm{SiO}_{2}(15 \rightarrow$ $25 \%$ EtOAc in hexanes eluent) to obtain $29.0 \mathrm{mg}$ of a white solid, $78 \%$, as a single diastereomer (according to ${ }^{1} \mathrm{H}$ NMR analysis).

${ }^{1} \mathrm{H}$ NMR (400 MHz, $\left.\mathrm{CDCl}_{3}\right): \delta 7.19(\mathrm{~d}, J=8.2 \mathrm{~Hz}, 2 \mathrm{H}), 7.05(\mathrm{~d}, J=8.2 \mathrm{~Hz}, 2 \mathrm{H}), 6.76(\mathrm{~s}, 2 \mathrm{H})$, $4.45(\mathrm{~d}, J=3.4 \mathrm{~Hz}, 1 \mathrm{H}), 4.38(\mathrm{~d}, J=3.4 \mathrm{~Hz}, 1 \mathrm{H}), 2.52(\mathrm{~s}, 7 \mathrm{H}), 2.24(\mathrm{~s}, 3 \mathrm{H}), 1.68(\mathrm{~d}, J=9.4 \mathrm{~Hz}$, $3 \mathrm{H}), 1.62(\mathrm{~d}, J=9.4 \mathrm{~Hz}, 3 \mathrm{H}) \mathrm{ppm}$.

${ }^{13} \mathrm{C}\left\{{ }^{1} \mathrm{H}\right\} \mathrm{NMR}\left(100 \mathrm{MHz}, \mathrm{CDCl}_{3}\right): \delta 140.8,138.6,137.3,136.9,133.0,130.9,128.4,128.2$, 57.7, 48.7, 47.3, 28.2, 21.0, $19.6 \mathrm{ppm}$.

HRMS calc'd for $\left[\mathrm{C}_{21} \mathrm{H}_{24} \mathrm{CINOS}+\mathrm{H}\right]^{+}=374.1345$, found 374.1359 .

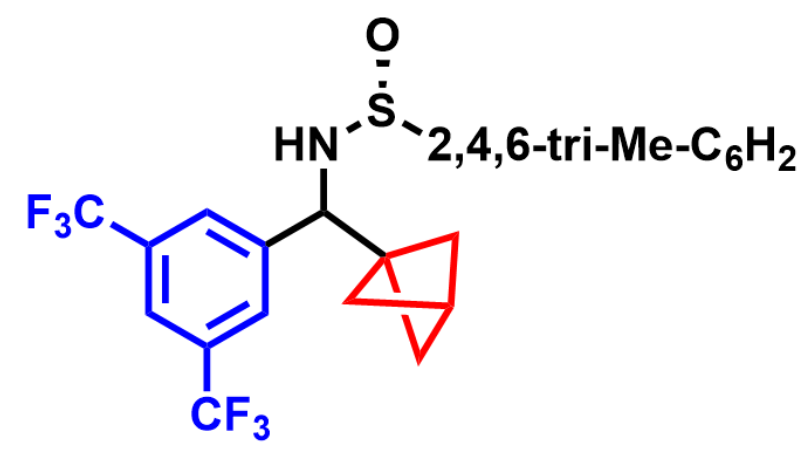

\section{$N$-(bicyclo[1.1.1]pentan-1-yl(3,5-bis(trifluoromethyl)phenyl)methyl)-1-mesityl-1- $\left(\boldsymbol{\Lambda}^{\mathbf{1}}\right.$ - oxidaneyl)- $\kappa^{3}$-sulfanamine $(9 e)$}

Prepared according to General Procedure B on $0.1 \mathrm{mmol}$ scale. The product was purified by flash column chromatography on $\mathrm{SiO}_{2}(10 \rightarrow 30 \%$ EtOAc in hexanes eluent) to obtain $24.2 \mathrm{mg}$ of a white solid, $51 \%$, as a single diastereomer (according to ${ }^{1} \mathrm{H}$ NMR analysis).

${ }^{1} \mathrm{H} \mathrm{NMR}\left(400 \mathrm{MHz}, \mathrm{CDCl}_{3}\right): \delta 7.55(\mathrm{~s}, 1 \mathrm{H}), 7.38(\mathrm{~s}, 2 \mathrm{H}), 6.50(\mathrm{~s}, 2 \mathrm{H}), 4.75(\mathrm{~d}, J=2.6 \mathrm{~Hz}, 1 \mathrm{H})$, $4.45(\mathrm{~d}, J=2.6 \mathrm{~Hz}, 1 \mathrm{H}), 2.58(\mathrm{~s}, 1 \mathrm{H}), 2.46(\mathrm{~s}, 6 \mathrm{H}), 2.06(\mathrm{~s}, 3 \mathrm{H}), 1.66(\mathrm{dd}, J=9.5,1.6 \mathrm{~Hz}, 3 \mathrm{H})$, $1.60(\mathrm{dd}, J=9.5,1.6 \mathrm{~Hz}, 3 \mathrm{H})^{*} \mathrm{ppm}$.

${ }^{13} \mathrm{C}\left\{{ }^{1} \mathrm{H}\right\} \mathrm{NMR}\left(100 \mathrm{MHz}, \mathrm{CDCl}_{3}\right): \delta 142.7,140.9,137.2,134.4,131.1,131.0\left(\mathrm{q}, J_{\mathrm{C}-\mathrm{F}}=33 \mathrm{~Hz}\right)$, $126.4,123.3\left(\mathrm{q}, J_{\mathrm{C}-\mathrm{F}}=272 \mathrm{~Hz}\right), 120.6\left(\mathrm{q}, J_{\mathrm{C}-\mathrm{F}}=4.1 \mathrm{~Hz}\right), 54.8,48.2,47.0,28.1,20.6,19.6 \mathrm{ppm}$.

HRMS calc'd for $\left[\mathrm{C}_{23} \mathrm{H}_{23} \mathrm{~F}_{6} \mathrm{NOS}+\mathrm{H}\right]^{+}=476.1483$ found 476.1477 .

*Signal overintegrates in spectrum to $4 \mathrm{H}$ due to overlapping signal with residual $\mathrm{H}_{2} \mathrm{O}$. 


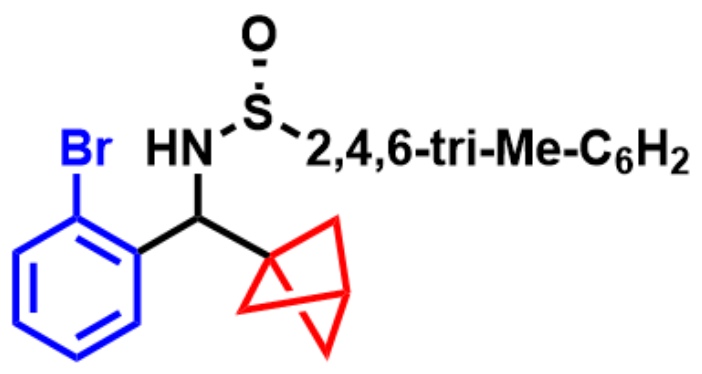

\section{$N$-(bicyclo[1.1.1]pentan-1-yl(2-bromophenyl)methyl)-1-mesityl-1-( $\boldsymbol{\kappa}^{\mathbf{1}}$-oxidaneyl)- $\boldsymbol{\Lambda}^{\mathbf{3}}$ - sulfanamine (9f)}

Prepared according to General Procedure B, adding 4 volumes of $\mathrm{CH}_{2} \mathrm{Cl}_{2}$ to facilitate solubility. The product was purified by flash column chromatography on $\mathrm{SiO}_{2}(60 \rightarrow 80 \%$ EtOAc in hexanes) to obtain $19.6 \mathrm{mg}$ of a white solid, $58 \%$, as a single diastereomer (according to ${ }^{1} \mathrm{H}$ NMR analysis).

${ }^{1} \mathrm{H}$ NMR (400 MHz, $\left.\mathrm{CDCl}_{3}\right): \delta 7.45(\mathrm{dd}, J=7.9,1 \mathrm{~Hz}, 1 \mathrm{H}), 7.24-7.16(\mathrm{~m}, 2 \mathrm{H}), 7.03(\mathrm{td}, J=7.9$, $1.9 \mathrm{~Hz}, 1 \mathrm{H}), 6.75$ (s, 2H), 5.00 (br s, 1H), 4.47 (br s, 1H), 2.53 (s, 6H), 2.49 (s, 1H), 2.22 (s, 3H), $1.72(\mathrm{dd}, J=9.5,1.8 \mathrm{~Hz}, 3 \mathrm{H}), 1.64(\mathrm{dd}, J=9.5,1.8 \mathrm{~Hz}, 3 \mathrm{H}) \mathrm{ppm}$.

${ }^{13} \mathrm{C}\left\{{ }^{1} \mathrm{H}\right\}$ NMR $\left(100 \mathrm{MHz},\left(\mathrm{CD}_{3}\right){ }_{2} \mathrm{CO}\right): \delta 148.6,148.2,141.1,141.0,138.1,136.9,136.8,135.8$, 131.6, 123.8, 53.4, 49.3, 47.73, 28.5, 20.9, $19.9 \mathrm{ppm}$.

HRMS calc'd for $\left[\mathrm{C}_{21} \mathrm{H}_{24 \mathrm{Br}} \mathrm{NOS}+\mathrm{Na}\right]^{+}=440.0660$, found 440.0656 .

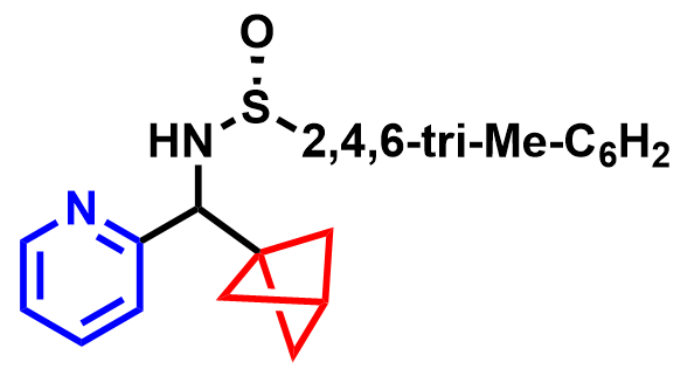

\section{$N$-(bicyclo[1.1.1]pentan-1-yl(pyridin-2-yl)methyl)-1-mesityl-1-( $\boldsymbol{\Lambda}^{1}$-oxidaneyl)- $\boldsymbol{\kappa}^{3}$ - sulfanamine $(9 \mathrm{~g})$}

Prepared according to General Procedure B . The product was purified by flash column chromatography on $\mathrm{SiO}_{2}(30 \% \rightarrow 80$ EtOAc in hexanes eluent) to obtain $20.8 \mathrm{mg}$ of a white solid, $61 \%$, d.r. $>20: 1$ by ${ }^{1} \mathrm{H}$ NMR analysis.

${ }^{1} \mathrm{H} \mathrm{NMR}\left(\mathrm{CDCl}_{3}, 400 \mathrm{MHz}\right): \delta 8.51(\mathrm{~d}, J=4.5 \mathrm{~Hz}, 1 \mathrm{H}), 7.60(\mathrm{td}, J=7.6,1.7 \mathrm{~Hz}, 1 \mathrm{H}), 7.16-7.11$ $(\mathrm{m}, 2 \mathrm{H}), 6.84(\mathrm{~s}, 2 \mathrm{H}), 6.09(\mathrm{~d}, J=6.6 \mathrm{~Hz}, 1 \mathrm{H}), 4.54(\mathrm{~d}, J=6.6 \mathrm{~Hz}, 1 \mathrm{H}), 2.58(\mathrm{~s}, 6 \mathrm{H}), 2.48$ (s, $1 \mathrm{H}), 2.27(\mathrm{~s}, 3 \mathrm{H}), 1.61(\mathrm{t}, J=9.4 \mathrm{~Hz}, 6 \mathrm{H}) \mathrm{ppm}$. 
${ }^{13} \mathrm{C}\left\{{ }^{1} \mathrm{H}\right\}$ NMR $\left(\mathrm{CDCl}_{3}, 126 \mathrm{MHz}\right): \delta 158.3,148.7,140.5,138.6,136.7,136.2,130.7,122.2$, 122.1, 59.6, 48.5, 47.6, 28.2, 21.1, 19.6. ppm.

HRMS calc'd for $\left[\mathrm{C}_{20} \mathrm{H}_{24} \mathrm{~N}_{2} \mathrm{OS}+\mathrm{Na}\right]^{+}=363.1507$, found 363.1502 .

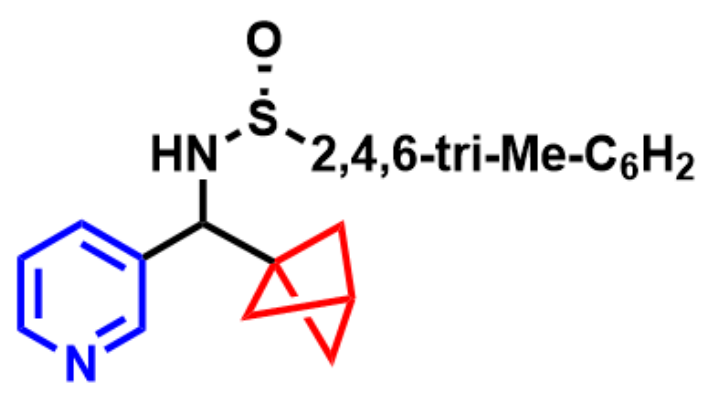

\section{$N$-(bicyclo[1.1.1]pentan-1-yl(pyridin-3-yl)methyl)-1-mesityl-1-( $\hat{\kappa}^{1}$-oxidaneyl)- $\hat{K}^{3}$ -} sulfanamine (9h)

Prepared according to General Procedure B. The product was purified by flash column chromatography on $\mathrm{SiO}_{2}(60 \rightarrow 80 \%$ EtOAc in hexanes) to obtain $19.6 \mathrm{mg}$ of a white solid, $58 \%$, as a single diastereomer (according to ${ }^{1} \mathrm{H}$ NMR analysis).

${ }^{1} \mathrm{H}$ NMR (400 MHz, CDCl $): \delta 8.41(\mathrm{dd}, J=5.1,1.6 \mathrm{~Hz}, 1 \mathrm{H}), 8.34(\mathrm{~d}, \mathrm{~J}=2 \mathrm{~Hz}, 1 \mathrm{H}), 7.42(\mathrm{tt}, J=$ 7.9, $1.9 \mathrm{~Hz}, 1 \mathrm{H}), 7.11(\mathrm{dd}, J=7.8,4.8 \mathrm{~Hz}, 1 \mathrm{H}), 6.72(\mathrm{~s}, 2 \mathrm{H}), 4.54(\mathrm{~d}, J=3.8 \mathrm{~Hz}, 1 \mathrm{H}), 4.42(\mathrm{~d}, J$ $=3.7 \mathrm{~Hz}, 1 \mathrm{H}), 2.55(\mathrm{~s}, 1 \mathrm{H}), 2.52(\mathrm{~s}, 6 \mathrm{H}), 2.21(\mathrm{~s}, 3 \mathrm{H}), 1.70(\mathrm{dd}, J=9.6,1.7, \mathrm{~Hz}, 3 \mathrm{H}), 1.64(\mathrm{dd}, J$ $=9.5,1.7 \mathrm{~Hz}, 3 \mathrm{H}) \mathrm{ppm}$.

${ }^{13} \mathrm{C}\left\{{ }^{1} \mathrm{H}\right\}$ NMR $\left(100 \mathrm{MHz}, \mathrm{CDCl}_{3}\right): \delta 148.6,148.4,140.8,136.9,136.7,135.6,134.2,131.0$, $123.1,55.7,48.6,47.3,28.4,21.0,19.8 \mathrm{ppm}$.

HRMS calc'd for $\left[\mathrm{C}_{20} \mathrm{H}_{24} \mathrm{~N}_{2} \mathrm{OS}+\mathrm{H}\right]^{+}=341.1688$, found 341.1693 .

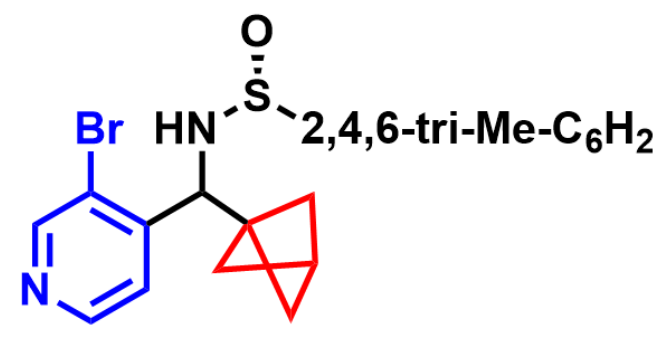

$N$-(bicyclo[1.1.1]pentan-1-yl(3-bromopyridin-4-yl)methyl)-1-mesityl-1-( $\boldsymbol{\kappa}^{1}$-oxidaneyl)- ${ }^{3}{ }^{3}$ sulfanamine (9i)

Prepared according to General Procedure B on $0.1 \mathrm{mmol}$ scale, adding 1 volume of $\mathrm{CH}_{2} \mathrm{Cl}_{2}$ to facilitate solubility. The product was purified by flash column chromatography on $\mathrm{SiO}_{2}(40 \rightarrow$ 
$60 \%$ EtOAc in hexanes) to obtain $15.4 \mathrm{mg}$ of a yellow solid, $44 \%$, as a single diastereomer (according to ${ }^{1} \mathrm{H}$ NMR analysis).

${ }^{1} \mathrm{H}$ NMR (400 MHz, $\left.\mathrm{CDCl}_{3}\right): \delta 8.52(\mathrm{~s}, 1 \mathrm{H}), 8.27(\mathrm{~d}, J=5.0 \mathrm{~Hz}, 1 \mathrm{H}), 7.03(\mathrm{~d}, J=5.0 \mathrm{~Hz}, 1 \mathrm{H})$, $6.66(\mathrm{~s}, 2 \mathrm{H}), 5.00(\mathrm{~d}, J=4.3 \mathrm{~Hz}, 1 \mathrm{H}), 4.51(\mathrm{br} \mathrm{s}, 1 \mathrm{H}), 2.51(\mathrm{~s}, 7 \mathrm{H}),{ }^{*} 2.18(\mathrm{~s}, 3 \mathrm{H}), 1.71(\mathrm{dd}, J=$ 9.5, $1.9 \mathrm{~Hz}, 3 \mathrm{H}), 1.63(\mathrm{dd}, J=9.5,1.9 \mathrm{~Hz}, 3 \mathrm{H}) \mathrm{ppm}$.

${ }^{13} \mathrm{C}\left\{{ }^{1} \mathrm{H}\right\} \mathrm{NMR}\left(100 \mathrm{MHz}, \mathrm{CDCl}_{3}\right): \delta 151.8,148.3,147.8,140.9,137.2,135.8,131.0,122.9$, $121.4,48.7,46.5,45.9,28.0,20.9,19.8 \mathrm{ppm}$.

HRMS calc'd for $\left[\mathrm{C}_{20} \mathrm{H}_{23} \mathrm{BrN}_{2} \mathrm{OS}+\mathrm{Na}+\mathrm{MeCN}\right]^{+}=482.0878$, found 482.0866.

*The singlet at $\delta 2.51$ presents as $7 \mathrm{H}$ due to the overlap the $\mathrm{BCP} \mathrm{C}-\mathrm{H}$ and the mesityl $\mathrm{CH}_{3} \times 2$.

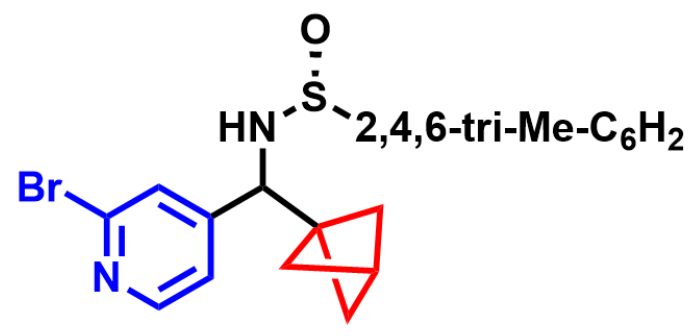

\section{$N$-(bicyclo[1.1.1]pentan-1-yl(2-bromopyridin-4-yl)methyl)-1-mesityl-1-( $\mathfrak{\Lambda}^{\mathbf{1}}$-oxidaneyl)- $\boldsymbol{\Lambda}^{\mathbf{3}}$ - sulfanamine $(\mathbf{9 j})$}

Prepared according to the General Procedure B on $0.1 \mathrm{mmol}$ scale, adding 1 volume of $\mathrm{CH}_{2} \mathrm{Cl}_{2}$ to facilitate solubility. The product was purified by flash column chromatography on $\mathrm{SiO}_{2}(10 \rightarrow$ $25 \%$ EtOAc in hexanes eluent) to obtain $17.7 \mathrm{mg}$ of a white solid, $42 \%$.

${ }^{1} \mathrm{H}$ NMR $\left(400 \mathrm{MHz}, \mathrm{CDCl}_{3}\right): \delta 8.10(\mathrm{~d}, J=5.0 \mathrm{~Hz}, 1 \mathrm{H}), 7.02(\mathrm{br} \mathrm{s}, 1 \mathrm{H}), 6.89(\mathrm{dd}, J=5.0,1.3$ $\mathrm{Hz}, 1 \mathrm{H}), 6.65(\mathrm{~s}, 2 \mathrm{H}), 4.52(\mathrm{~d}, J=3.5 \mathrm{~Hz}, 1 \mathrm{H}), 4.39(\mathrm{~d}, J=3.4 \mathrm{~Hz}, 1 \mathrm{H}), 2.57(\mathrm{~s}, 1 \mathrm{H}), 2.49$ (s, $6 \mathrm{H}), 2.19$ (s, 3H), 1.64 (ddd, $J=22,9.5,1.7 \mathrm{~Hz}, 6 \mathrm{H}) \mathrm{ppm}$.

${ }^{13} \mathrm{C}\left\{{ }^{1} \mathrm{H}\right\} \mathrm{NMR}\left(100 \mathrm{MHz}, \mathrm{CDCl}_{3}\right): \delta 152.0,149.4,142.0,141.2,137.2,135.3,131.1,125.7$, 120.9, 55.2, 48.5, 46.5, 28.1, 21.0, 19.7. ppm.

HRMS calc'd for $\left[\mathrm{C}_{20} \mathrm{H}_{23} \mathrm{BrN}_{2} \mathrm{OS}+\mathrm{Na}\right]^{+}=441.0612$, found 441.0601 .

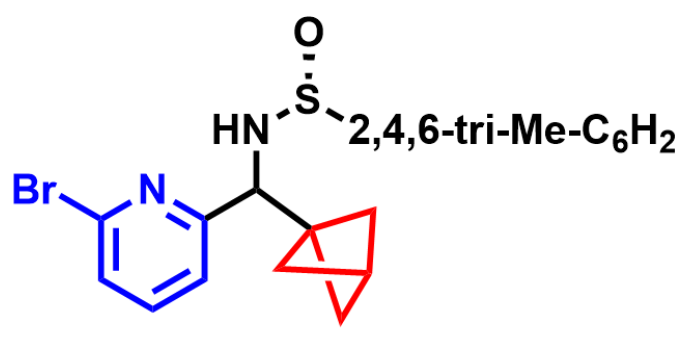


$N$-(bicyclo[1.1.1]pentan-1-yl(6-bromopyridin-2-yl)methyl)-1-mesityl-1-( $\boldsymbol{\kappa}^{1}$-oxidaneyl)- $\boldsymbol{K}^{3}$ sulfanamine (9k)

Prepared according to General Procedure B on $0.1 \mathrm{mmol}$ scale, adding 1 volume of $\mathrm{CH}_{2} \mathrm{Cl}_{2}$ to facilitate solubility. The product was purified by flash column chromatography on $\mathrm{SiO}_{2}(15 \rightarrow$ $25 \%$ EtOAc in hexanes eluent) to obtain $19.2 \mathrm{mg}$ of a white solid, $62 \%$, in approximately $16: 1$ diastereomeric ratio, based on ${ }^{1} \mathrm{H}$ NMR analysis of the purified mixture. (When visible, the minor diastereomer peaks are picked and integrated in the full spectrum below).

${ }^{1} \mathrm{H}$ NMR $\left(400 \mathrm{MHz}, \mathrm{CDCl}_{3}\right): \delta 7.46(\mathrm{t}, J=7.7 \mathrm{~Hz}, 1 \mathrm{H}), 7.32(\mathrm{~d}, J=7.7 \mathrm{~Hz}, 1 \mathrm{H}), 7.07(\mathrm{~d}, J=7.4$ $\mathrm{Hz}, 1 \mathrm{H}), 6.85(\mathrm{~s}, 2 \mathrm{H}), 5.87(\mathrm{~d}, J=7.7 \mathrm{~Hz}, 1 \mathrm{H}), 4.98$ (minor diastereomer; $\mathrm{d}, J=6.7 \mathrm{~Hz}, 1 \mathrm{H}$ ), 4.53 (minor diastereomer; d, $J=6.8 \mathrm{~Hz}, 1 \mathrm{H}), 4.46(\mathrm{~d}, J=7.7 \mathrm{~Hz}, 1 \mathrm{H}), 2.59(\mathrm{~s}, 6 \mathrm{H}), 2.50(\mathrm{~s}, 1 \mathrm{H})$, 2.48 (minor diastereomer; s, 1H), $2.28(\mathrm{~s}, 3 \mathrm{H}), 1.61(\mathrm{dd}, J=13,9.4 \mathrm{~Hz}, 6 \mathrm{H}) \mathrm{ppm}$.

${ }^{13} \mathrm{C}\left\{{ }^{1} \mathrm{H}\right\}$ NMR $\left(100 \mathrm{MHz}, \mathrm{CDCl}_{3}\right): \delta 160.1,141.3,140.6,136.6,138.3,136.9,130.8,126.5$, $120.7,59.4,48.5,47.2,28.2,21.1,19.5 \mathrm{ppm}$.

HRMS calc'd for $\left[\mathrm{C}_{20} \mathrm{H}_{23} \mathrm{BrN}_{2} \mathrm{OS}+\mathrm{Na}\right]^{+}=441.0612$, found 441.0604 .

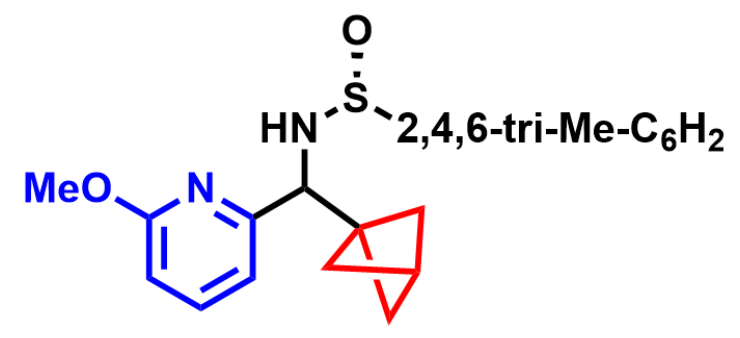

\section{$N$-(bicyclo[1.1.1]pentan-1-yl(6-methoxypyridin-2-yl)methyl)-1-mesityl-1-( $\kappa^{1}$-oxidaneyl)- $\kappa^{3}$ - sulfanamine (91)}

Prepared according to General Procedure B on $0.1 \mathrm{mmol}$ scale. The product was purified by flash column chromatography on $\mathrm{SiO}_{2}(15 \rightarrow 25 \%$ EtOAc in hexanes eluent) to obtain $18.0 \mathrm{mg}$ of a white solid, $50 \%$, as a single diastereomer (according to ${ }^{1} \mathrm{H}$ NMR analysis).

${ }^{1} \mathrm{H}$ NMR (400 MHz, $\left.\mathrm{CDCl}_{3}\right): \delta 7.49(\mathrm{dd}, J=8.2,7.2 \mathrm{~Hz}, 1 \mathrm{H}), 6.86(\mathrm{~s}, 2 \mathrm{H}), 6.70(\mathrm{~d}, J=7.1 \mathrm{~Hz}$, $1 \mathrm{H}), 6.60(\mathrm{~d}, J=8.2 \mathrm{~Hz}, 1 \mathrm{H}), 5.84(\mathrm{~d}, J=7.8 \mathrm{~Hz}, 1 \mathrm{H}), 4.41(\mathrm{~d}, J=7.8 \mathrm{~Hz}, 1 \mathrm{H}), 3.89$ (s, 3H), $2.58(\mathrm{~s}, 6 \mathrm{H}), 2.47$ (s, 1H), 2.29 (s, 3H), 1.60 (dd, $J=12,9.2 \mathrm{~Hz}, 6 \mathrm{H}) \mathrm{ppm}$.

${ }^{13} \mathrm{C}\left\{{ }^{1} \mathrm{H}\right\}$ NMR (100 MHz, $\left.\mathrm{CDCl}_{3}\right): \delta 163.5,156.3,140.5,139.0,138.9,136.5,130.7,114.5$, 109.3, 60.3, 52.2, 48.6, 47.7, 27.9, 21.1, $19.6 \mathrm{ppm}$.

HRMS calc'd for $\left[\mathrm{C}_{21} \mathrm{H}_{26} \mathrm{~N}_{2} \mathrm{O}_{2} \mathrm{~S}+\mathrm{H}\right]^{+}=371.1793$, found 371.1726. 


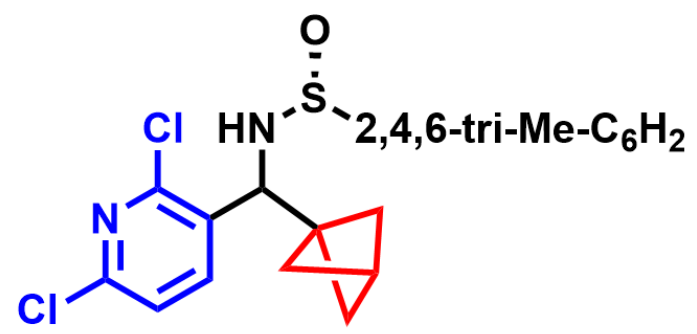

$N$-(bicyclo[1.1.1]pentan-1-yl(2,6-dichloropyridin-3-yl)methyl)-1-mesityl-1-( $\boldsymbol{\Lambda}^{\mathbf{1}}$-oxidaneyl)- $\boldsymbol{\Lambda}^{\mathbf{3}}$ sulfanamine (9m)

Prepared according to General Procedure B on $0.1 \mathrm{mmol}$ scale, adding 1 volume of $\mathrm{CH}_{2} \mathrm{Cl}_{2}$ to facilitate solubility. The product was purified by flash column chromatography on $\mathrm{SiO}_{2}(15 \rightarrow$ $25 \%$ EtOAc in hexanes eluent) to obtain $28.8 \mathrm{mg}$ of a white solid, $70 \%$, as a single diastereomer (according to ${ }^{1} \mathrm{H}$ NMR analysis).

${ }^{1} \mathrm{H} \mathrm{NMR}\left(400 \mathrm{MHz}, \mathrm{CDCl}_{3}\right): \delta 7.37(\mathrm{~d}, J=8.0 \mathrm{~Hz}, 1 \mathrm{H}), 6.98(\mathrm{~d}, J=8.0 \mathrm{~Hz}, 1 \mathrm{H}), 6.65(\mathrm{~s}, 2 \mathrm{H})$, $5.04(\mathrm{~d}, J=3.3 \mathrm{~Hz}, 1 \mathrm{H}), 4.46(\mathrm{br} \mathrm{s}, 1 \mathrm{H}), 2.53(\mathrm{~s}, 1 \mathrm{H}), 2.51(\mathrm{~s}, 6 \mathrm{H}), 2.19(\mathrm{~s}, 3 \mathrm{H}), 1.68(\mathrm{ddd}, J=$ $22,9.5,1.8 \mathrm{~Hz}, 6 \mathrm{H}) \mathrm{ppm}$.

${ }^{13} \mathrm{C}\left\{{ }^{1} \mathrm{H}\right\} \mathrm{NMR}\left(100 \mathrm{MHz},\left(\mathrm{CDCl}_{3}\right): \delta 148.4,148.2,141.1,139.1,137.3,135.3,133.5,131.0\right.$, 122.6, 52.1, 48.6, 46.7, 27.9, 20.9, 19.8 ppm.

HRMS calc'd for $\left[\mathrm{C}_{20} \mathrm{H}_{22} \mathrm{Cl}_{2} \mathrm{~N}_{2} \mathrm{OS}+\mathrm{Na}\right]^{+}=431.0728$, found 431.0717 .

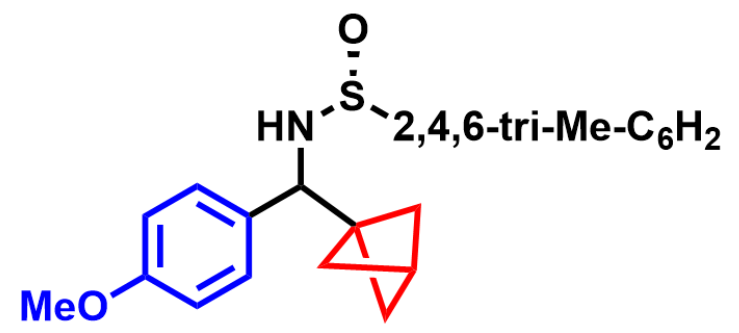

$N$-(bicyclo[1.1.1]pentan-1-yl(4-methoxyphenyl)methyl)-1-mesityl-1-( $\boldsymbol{\Lambda}^{\mathbf{1}}$-oxidaneyl)- $\boldsymbol{\Lambda}^{\mathbf{3}}$ sulfanamine (9n)

Prepared according to General Procedure B on $0.1 \mathrm{mmol}$ scale. The product was purified by flash column chromatography on $\mathrm{SiO}_{2}(15 \rightarrow 25 \%$ EtOAc in hexanes eluent) to obtain $11 \mathrm{mg}$ of a white solid, $30 \%$, as a single diastereomer (according to ${ }^{1} \mathrm{H}$ NMR analysis).

${ }^{1} \mathrm{H}$ NMR (400 MHz, $\left.\mathrm{CDCl}_{3}\right): \delta 7.09(\mathrm{~d}, J=8.6 \mathrm{~Hz}, 2 \mathrm{H}), 6.80-6.78(\mathrm{~m}, 4 \mathrm{H}), 4.41$ (d, $J=3.3 \mathrm{~Hz}$, $1 \mathrm{H}), 4.35(\mathrm{~d}, J=3.2 \mathrm{~Hz}, 1 \mathrm{H}), 3.78(\mathrm{~s}, 3 \mathrm{H}), 2.53(\mathrm{~s}, 6 \mathrm{H}), 2.51(\mathrm{~s}, 1 \mathrm{H}), 2.26(\mathrm{~s}, 3 \mathrm{H}), 1.71(\mathrm{dd}, J=$ 9.5, 1.6 Hz, 3H), $1.64(\mathrm{dd}, J=9.5,1.6 \mathrm{~Hz}, 3 \mathrm{H}) \mathrm{ppm}$.

${ }^{13} \mathrm{C}\left\{{ }^{1} \mathrm{H}\right\} \mathrm{NMR}\left(100 \mathrm{MHz}, \mathrm{CDCl}_{3}\right): \delta 159.0,140.7,138.1,136.9,132.5,130.9,128.2,113.8$, 58.2, 55.4, 49.0, 47.6, 28.4, 21.1, 19.7. ppm.

HRMS calc'd for $\left[\mathrm{C}_{22} \mathrm{H}_{27} \mathrm{NO}_{2} \mathrm{~S}+\mathrm{H}\right]^{+}=370.1841$ found 370.1845 . 


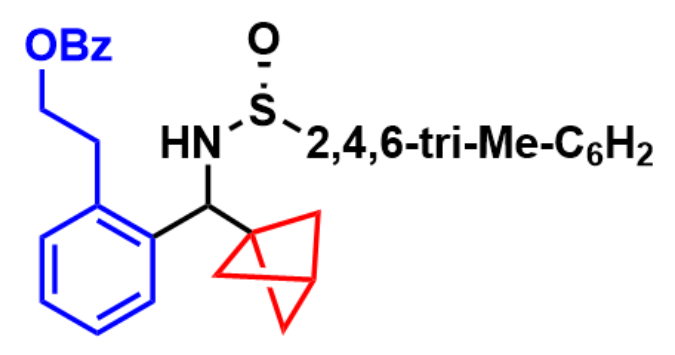

\section{2-(bicyclo[1.1.1]pentan-1-yl((mesityl( $\lambda^{1}$-oxidaneyl)- $\lambda^{3}$-sulfaneyl)amino)methyl)phenethyl benzoate (90)}

Prepared according to General Procedure B on $0.16 \mathrm{mmol}$ scale. The product was purified by flash column chromatography on $\mathrm{SiO}_{2}(20 \rightarrow 60 \%$ EtOAc in hexanes eluent) to obtain $37.7 \mathrm{mg}$ of a white solid, $48 \%$, as a single diastereomer (according to ${ }^{1} \mathrm{H}$ NMR analysis).

${ }^{1} \mathrm{H}$ NMR $\left(400 \mathrm{MHz}, \mathrm{CDCl}_{3}\right): \delta 8.05-8.03(\mathrm{~m}, 2 \mathrm{H}), 7.56(\mathrm{tt}, J=7.4,1.8 \mathrm{~Hz}, 1 \mathrm{H}), 7.46-7.42(\mathrm{~m}$, $2 \mathrm{H}), 7.27-7.18(\mathrm{~m}, 4 \mathrm{H}), 6.81(\mathrm{~s}, 2 \mathrm{H}), 4.87(\mathrm{~d}, J=4.0 \mathrm{~Hz}, 1 \mathrm{H}), 4.55-4.40(\mathrm{~m}, 3 \mathrm{H}), 3.16-3.03(\mathrm{~m}$, $2 \mathrm{H}), 2.52(\mathrm{~s}, 7 \mathrm{H}),{ }^{*} 2.24(\mathrm{~s}, 3 \mathrm{H}), 1.79(\mathrm{dd}, J=9.5,1.6 \mathrm{~Hz}, 3 \mathrm{H}), 1.72(\mathrm{dd}, J=9.4,1.5 \mathrm{~Hz}, 3 \mathrm{H})$ ppm.

${ }^{13} \mathrm{C}\left\{{ }^{1} \mathrm{H}\right\}$ NMR $\left(100 \mathrm{MHz}, \mathrm{CDCl}_{3}\right): \delta 166.5,140.8,138.8,138.0,136.9,134.8,133.0,130.9$, $130.3,130.2,129.7,128.4,127.5,127.3,127.0,64.7,53.8,49.2,47.4,43.2,28.4,22.4,19.6$ ppm.

HRMS calc'd for $\left[\mathrm{C}_{30} \mathrm{H}_{33} \mathrm{NO}_{3} \mathrm{~S}+\mathrm{Na}\right]^{+}=510.2079$, found 510.2093.

*The singlet at $\delta 2.52$ presents as $7 \mathrm{H}$ due to the overlap the BCP C- $H$ and the mesityl $\mathrm{CH}_{3} \times 2$.

\section{Optimization of larger (>0.3 $\mathbf{m m o l}$ ) scale procedure for MH HAT propellylation of imines}

In addition to the necessity of ice bath chilling during silane addition, we found on scales larger than $0.3 \mathrm{mmol}$ that extremely slow addition of the silane was necessary to achieve the desired reactivity. The standard conditions (silane added over 3-5 min) were successful on 0.1 and 0.3 mmol reaction scale and produce $62 \%$ and $57 \%$ isolated yields, respectively, in >20:1 d.r, of the 4-Cl substituted BCP product (Table S1, entries 1 and 2). However, on $0.5 \mathrm{mmol}$ scale, addition of 3 equiv $(0.24 \mathrm{~mL}) \mathrm{Ph}(\mathrm{OiPr}) \mathrm{SiH}_{2}$ at a rate of 1 drop every 15-20 seconds produced a poor result of $31 \%$ yield with 1:1 d.r.. Further, on the $1.0 \mathrm{mmol}$ scale, adding the silane over 12 minutes, no reaction product is observed, with $50 \%$ starting material sulfinimine recovered after chromatography and no other products (e.g. reduction of starting material) detected (entries 3 and 4). By slowing the silane addition to 1 drop per minute over 40 minutes or 1 drop per minute 
over 90 minutes on 0.5 and $1.0 \mathrm{mmol}$ scales, respectively, good yields of 72 and $73 \%$ in >20:1 d.r. were obtained. Our working hypothesis is that relatively "fast" addition of silane (e.g. entries 3-4) promotes the formation of a metal hydride that is not productive in MH HAT propellylation (see in-text proposed mechanism) but rather favors off-cycle processes such as $\mathrm{H}_{2}$ evolution.

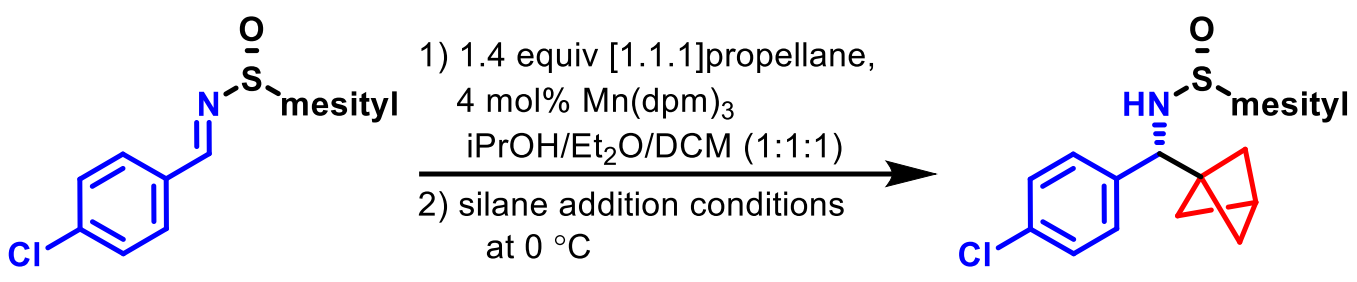

\begin{tabular}{|c|c|c|}
\hline Entry & $\begin{array}{c}\text { Reaction scale / total } \\
\text { time of silane addition } \\
\text { conditions }\end{array}$ & Result (yield, d.r.) \\
\hline 1 & $0.1 / 3-5 \mathrm{~min}$ & $62 \%,>20: 1$ d.r. \\
\hline 2 & $0.3 / 5 \mathrm{~min}$ & $57 \%,>20: 1$ d.r. \\
\hline 3 & $0.5 / 10 \mathrm{~min}$ & $31 \%, 1: 1$ d.r. \\
\hline 4 & $1.0 / 12 \mathrm{~min}$ & $\begin{array}{c}\text { No product }(50 \% \mathrm{SM} \\
\text { recovered) }\end{array}$ \\
\hline 5 & $\begin{array}{c}0.5 / 1 \text { drop silane per } \\
\text { minute for 40 mins }\end{array}$ & $\begin{array}{c}73 \%,>20: 1 \text { d.r. } \\
1.0 / 1 \text { drop silane per } \\
\text { minute for } 90 \text { minutes }\end{array}$ \\
\hline 6 & $72 \%,>20: 1$ d.r. \\
\hline
\end{tabular}

Table S1. Optimzation of silane addition.

Procedure for 1.0 mmol scale propellylation (Table S1, entry 6):

To an oven-dried $20 \mathrm{~mL}$ screwcap vial (septum-lined cap) charged with a stir bar, the 4-Cl substituted mesityl sulfinimine (1-(4-chlorophenyl)- $N$-(mesityl $\left(\Lambda^{1}\right.$-oxidaneyl)- $\Lambda^{3}$ sulfaneyl)methanimine) is added ( $305.8 \mathrm{mg}, 1.0 \mathrm{mmol}, 1$ equiv). The vial is brought under a nitrogen atmosphere of a glovebox and $\mathrm{Mn}(\mathrm{dpm})_{3}(24.0 \mathrm{mg}, 4 \mathrm{~mol} \%)$ is added. $2.37 \mathrm{~mL}$ each of iPrOH, $\mathrm{CH}_{2} \mathrm{Cl}_{2}$, and a $0.59 \mathrm{M}$ stock solution of [1.1.1]propellane in $\mathrm{Et}_{2} \mathrm{O}$ are added. The vial is capped, removed from the glovebox, and brought to the Schlenk line and placed under a nitrogen atmosphere with an inlet needle. After chilling to $0{ }^{\circ} \mathrm{C}$ in an ice bath, $\mathrm{Ph}(\mathrm{OiPr}) \mathrm{SiH}_{2}(0.54 \mathrm{~mL}$, $3.0 \mathrm{mmol}, 3$ equiv) is added at a rate of 1 drop per minute for 90 minutes. Over the course of this addition, the reaction decolorizes from an opaque dark brown to a clear light orange, with the decolorization having occurred completely after 60 minutes of silane addition. The reaction is stirred 10 mins further at this temperature and then warmed to room temperature and stirred for 72 hours. At the end of the reaction period, the mixture is poured into a separatory funnel containing $50 \mathrm{~mL}$ saturated EDTA solution. The aqueous layer is extracted twice with $30 \mathrm{~mL}$ EtOAc. The combined organic layers are washed with $50 \mathrm{~mL}$ brine, dried over $\mathrm{MgSO}_{4}$, filtered, and concentrated to a thick yellow oil. The crude material is loaded onto a $25 \mathrm{G}$ Biotage SNAP cartridge filled with silica gel and purified with a gradient of $15 \rightarrow 25 \%$ EtOAc/hexanes to yield the product as a white solid, $270.4 \mathrm{mg}, 73 \%$, >20:1 d.r. by ${ }^{1} \mathrm{H}$ NMR analysis. 


\section{BCP product deprotection}

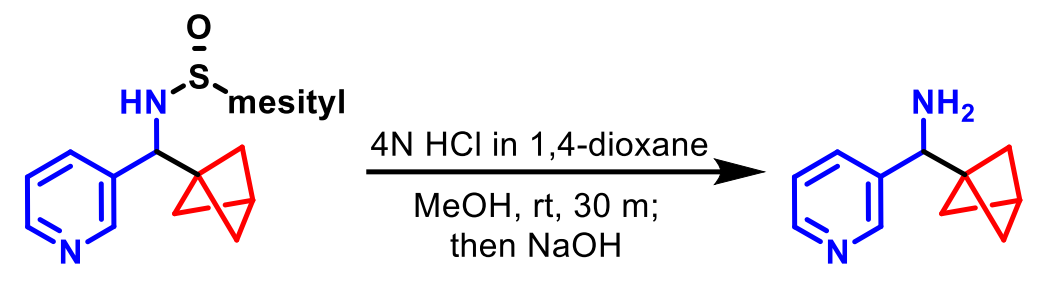

\section{bicyclo[1.1.1]pentan-1-yl(pyridin-3-yl)methanamine (14a)}

To a $4 \mathrm{~mL}$ vial charged with a stir bar and the sulfanamide (18.3 $\mathrm{mg}, 0.054 \mathrm{mmol}, 1$ equiv) was added $0.5 \mathrm{~mL} \mathrm{MeOH}$ under an air atmosphere. The solution was cooled to $0{ }^{\circ} \mathrm{C}$ and $0.1 \mathrm{~mL} 4 \mathrm{~N}$ $\mathrm{HCl}$ in 1,4-dioxane (Alfa Aesar) is added dropwise over 30 seconds. The reaction mixture is stirred 2 minutes and then removed from the ice bath and stirred at ambient temperature for 30 minutes. At the end of this period, volatiles are removed under reduced pressure to yield a crude solid. The solid is transferred to a separatory funnel using $10 \mathrm{~mL}$ water and $5 \mathrm{~mL}$ EtOAc. The layers are separated, and the aqueous layer is washed again with $5 \mathrm{~mL}$ EtOAc. The aqueous layer is then basified with $1 \mathrm{~N} \mathrm{NaOH}$ until $\mathrm{pH} 14$ (as indicated by $\mathrm{pH}$ paper). The basic layer is washed with EtOAc $(3 \times 5 \mathrm{~mL})$. The combined organic layers are washed with $10 \mathrm{~mL}$ brine, dried over $\mathrm{MgSO}_{4}$, filtered, and concentrated to a thick, yellow oil, $8.5 \mathrm{mg}, 92 \%$.

${ }^{1} \mathrm{H}$ NMR (400 MHz, $\left.\mathrm{CDCl}_{3}\right): \delta 8.45-8.44(\mathrm{~m}, 2 \mathrm{H}), 7.57(\mathrm{~d}, J=7.8 \mathrm{~Hz}, 1 \mathrm{H}), 7.20(\mathrm{dd}, J=7.8,4.8$ Hz, 1H), 3.96 (s, 1H), 2.49 (s, 1H), 1.72 (br s, 2H), 1.58 (dd, $J=13,9.4$ Hz, 6H) ppm.

${ }^{13} \mathrm{C}\left\{{ }^{1} \mathrm{H}\right\} \mathrm{NMR}\left(100 \mathrm{MHz}, \mathrm{CDCl}_{3}\right): \delta 148.6,148.4,138.5,134.0,123.2,54.7,48.8,47.8,27.6$ ppm.

HRMS calc'd for $\left[\mathrm{C}_{11} \mathrm{H}_{14} \mathrm{~N}_{2}+\mathrm{H}\right]^{+}=175.1230$, found 175.1195 . 
SFC conditions: Chiralpak IG-3, $\mathrm{CO}_{2} / \mathrm{MeOH} / \mathrm{NEt}_{3}(90: 9.9: 0.1), 2.5 \mathrm{~mL} / \mathrm{min}, \Lambda=254 \mathrm{~nm}$ Racemate:

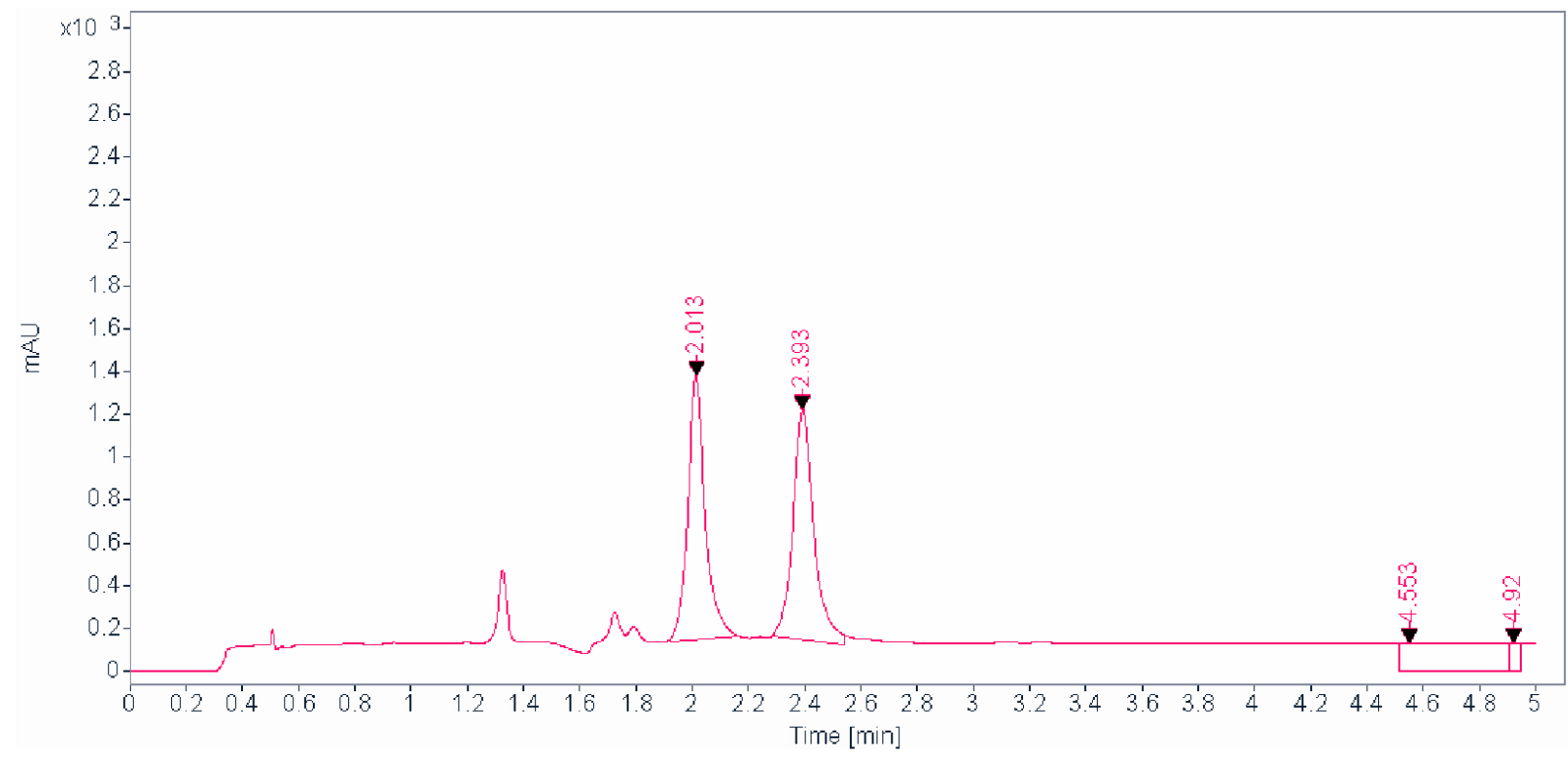

$\begin{array}{crrrl}\text { RT [min] Type } & \text { Width [min] } & \text { Area } & \text { Height } & \text { Area } \% \\ 2.013 \mathrm{MM} & 0.0723 & 5341.5986 & 1231.2573 & 53 \% \\ 2.393 \mathrm{MM} & 0.0863 & 5563.8511 & 1074.4304 & 47 \%\end{array}$

Enantioenriched sample:

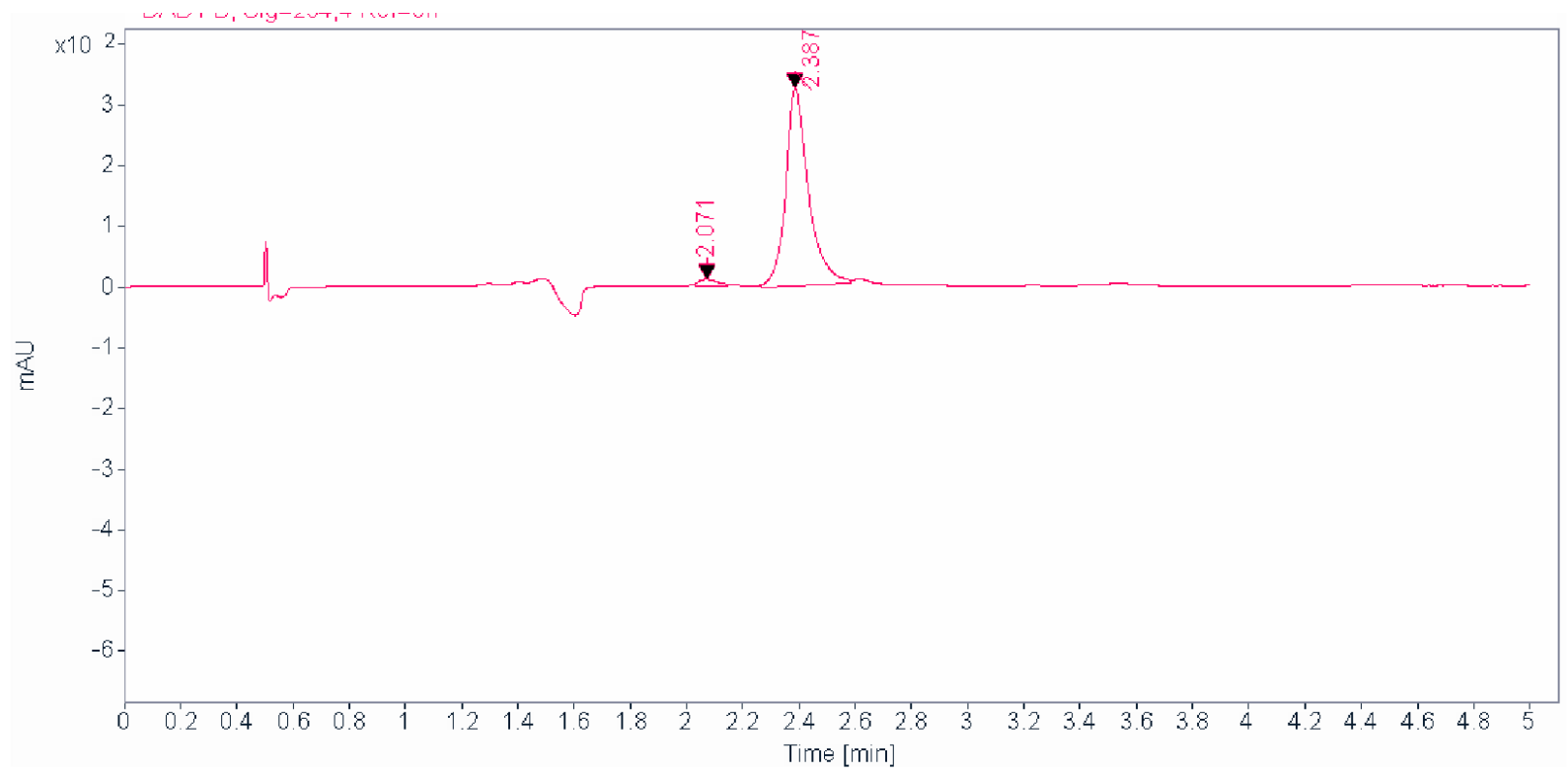




$\begin{array}{ccrrr}\text { RT [min] Type } & \text { Width [min] } & \text { Area } & \text { Height } & \text { Area\% } \\ 2.071 \mathrm{MM} & 0.0755 & 50.5885 & 11.1626 & 2.6751 \\ 2.387 \mathrm{MM} & 0.0943 & 1840.5070 & 325.4644 & 97.3249\end{array}$

\section{Synthesis of BCP piperazine core}

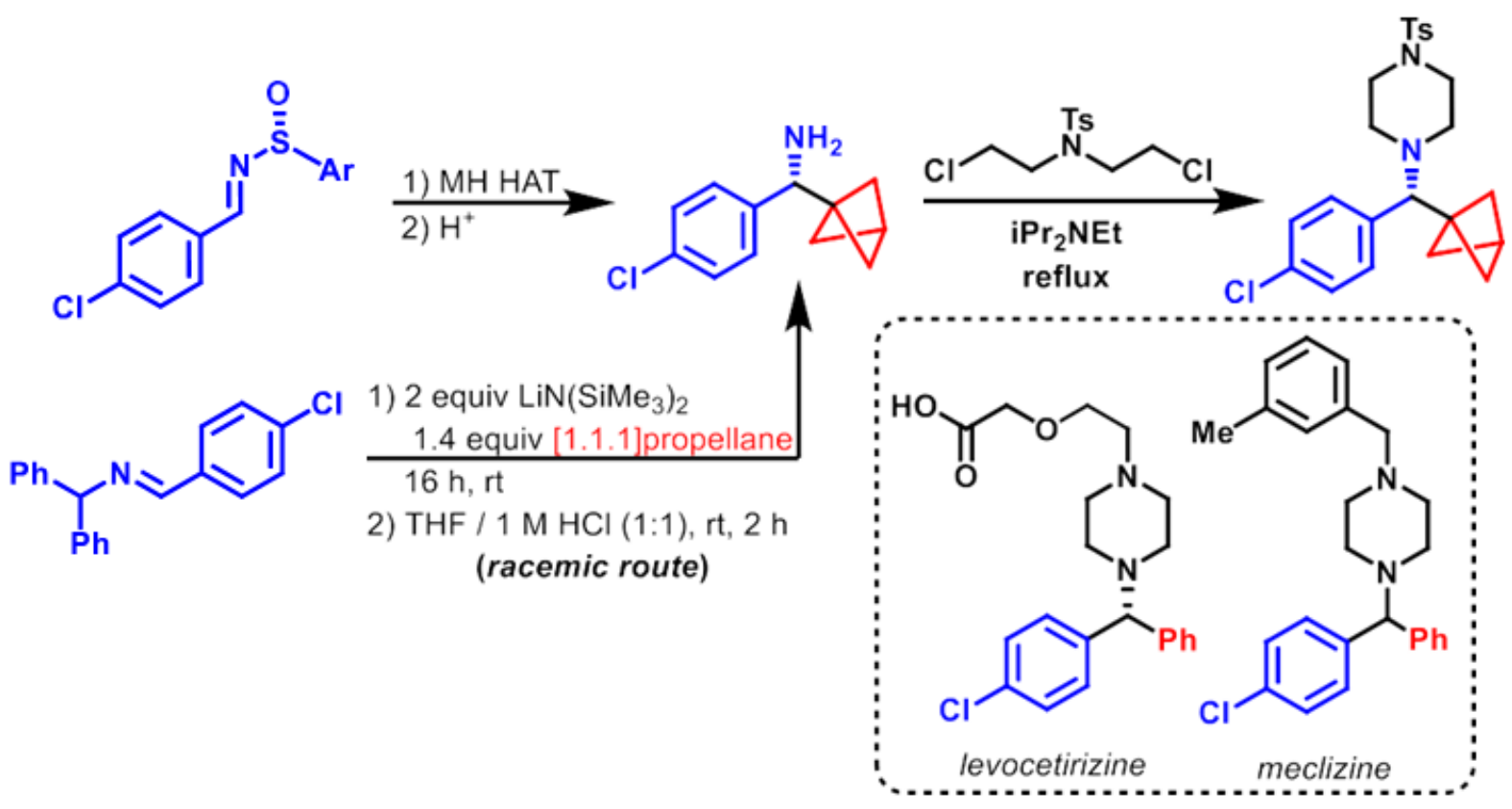

Figure S1. Racemic and enantioenriched routes to levocetirizine amide.

Synthesis of racemic bicyclo[1.1.1]pentan-1-yl(4-chlorophenyl)methanamine

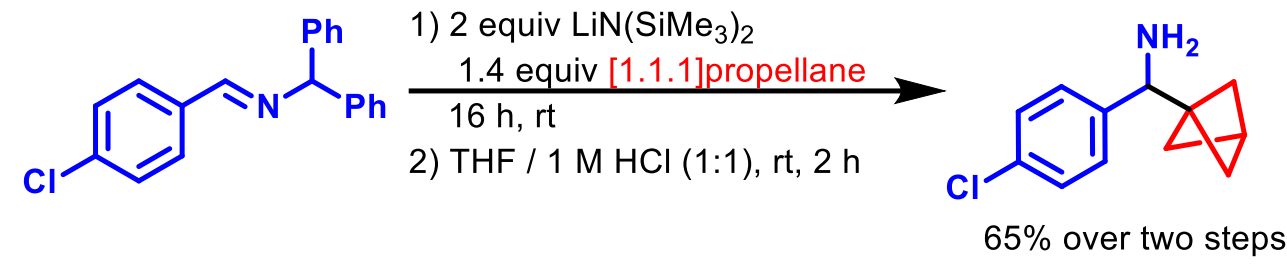

Analogous to previously described procedures, ${ }^{3}$ starting with aldimine instead of ketimine, and reducing the load of [1.1.1]propellane slightly from 2 equiv to 1.4 equiv. Under a nitrogen atmosphere in a glovebox, the aldimine (1.0301 g, $3.37 \mathrm{mmol}, 1$ equiv) and 2 equiv $\mathrm{LiN}\left(\mathrm{SiMe}_{3}\right)_{2}$ (1.1276 g, $6.74 \mathrm{mmol}, 2$ equiv) were added to a $40 \mathrm{~mL}$ vial charged with a stir bar. $17 \mathrm{~mL}$ THF and $8 \mathrm{~mL}$ of a $0.59 \mathrm{M}$ stock solution of [1.1.1]propellane in $\mathrm{Et}_{2} \mathrm{O}$ ( $4.72 \mathrm{mmol}, 1.4$ equiv) were next added. The reaction vial was capped and brought out of the glovebox to a stir plate. The reaction was stirred 16 hours at room temperature. At the end of the reaction period, the cap was removed and several drops of water were added to the mixture to quench the reaction. The reaction mixture was poured into a separatory funnel containing $25 \mathrm{~mL}$ water and washed $2 \times 25$ $\mathrm{mL}$ with EtOAc. The combined organic layers were washed with $25 \mathrm{~mL}$ brine, dried over $\mathrm{MgSO}_{4}$, filter, and concentrated to a thick oil. The crude mixture was loaded onto a silica gel 
column and eluted with $4 \% \mathrm{NEt}_{3}$ in hexanes to deliver the propellylated ketimine as a thick orange oil, $950 \mathrm{mg}$. [Note: If the silica gel purification step was skipped and the crude material was immediately subjected to imine hydrolysis, a messy reaction mixture was obtained. It is necessary to purify the ketimine $\mathrm{BCP}$ product before proceeding to hydrolysis.

The orange oil was dissolved in $26 \mathrm{~mL}$ THF and charged to a $250 \mathrm{~mL}$ RBF containing a stir bar. The solution was cooled to $0{ }^{\circ} \mathrm{C}$ and $1 \mathrm{M} \mathrm{HCl}(26 \mathrm{~mL})$ was added dropwise over 5 minutes, producing a light yellow, clear solution. The mixture was brought to room temperature and stirred for 2 hours. At the end of this period, the organic volatiles were removed under rotary evaporation. The reaction mixture was poured into a separatory funnel with $20 \mathrm{~mL}$ water and extracted $3 \times 25 \mathrm{~mL} \mathrm{Et}_{2} \mathrm{O}$. The aqueous layer was then basified with $1 \mathrm{M} \mathrm{NaOH}$ until the $\mathrm{pH}$ was 14 as determined by $\mathrm{pH}$ paper. The aqueous layer was then extracted $5 \times 25 \mathrm{~mL} \mathrm{CH}_{2} \mathrm{Cl}_{2}$. The combined organic layers were dried over $\mathrm{MgSO}_{4}$, filtered, and concentrated under reduced pressure to a thick yellow oil, the primary BCP amine, $455.7 \mathrm{mg}, 65 \%$ over two steps.

${ }^{1} \mathrm{H} \mathrm{NMR}\left(600 \mathrm{MHz}, \mathrm{CDCl}_{3}\right): \delta 7.21(\mathrm{~d}, J=8.2 \mathrm{~Hz}, 2 \mathrm{H}), 7.10(\mathrm{~d}, J=8.2 \mathrm{~Hz}, 2 \mathrm{H}), 3.86(\mathrm{~s}, 1 \mathrm{H})$, $2.43(\mathrm{~s}, 1 \mathrm{H}), 1.51(\mathrm{dd}, J=14,9.4 \mathrm{~Hz}, 6 \mathrm{H}), 1.45$ (br s, 2H) ppm.

${ }^{13} \mathrm{C}\left\{{ }^{1} \mathrm{H}\right\} \mathrm{NMR}\left(125 \mathrm{MHz}, \mathrm{CDCl}_{3}\right): \delta 141.9,132.4,128.3,127.9,56.3,48.9,47.8,27.4 \mathrm{ppm}$.

HRMS calc'd for $\left[\mathrm{C}_{12} \mathrm{H}_{14} \mathrm{ClN}+\mathrm{H}\right]^{+}=208.0893$, found 208.0891 .

\section{Synthesis of enantioenriched material}

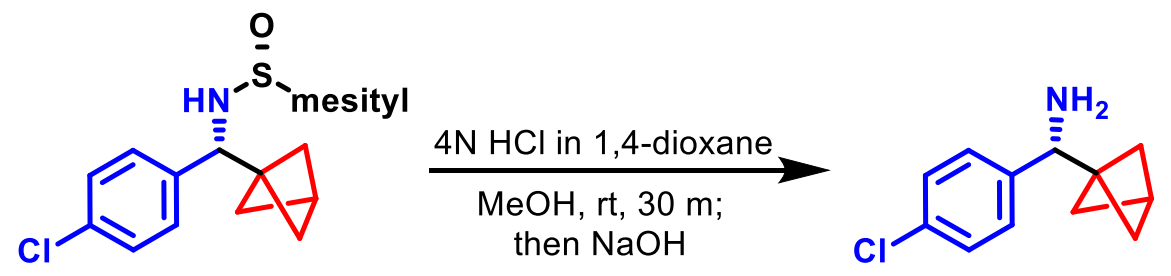

A $4 \mathrm{~mL}$ vial was charged with a stir bar and the sulfanamide ( $81.7 \mathrm{mg}, 0.22 \mathrm{mmol}, 1$ equiv) was dissolved in $1 \mathrm{~mL} \mathrm{MeOH}$ under an air atmosphere. The solution was cooled to $0{ }^{\circ} \mathrm{C}$ and $0.2 \mathrm{~mL}$ 4N HCl in 1,4-dioxane (Alfa Aesar) was added dropwise over 30 seconds. The reaction mixture was stirred 2 minutes and then removed from the ice bath and stirred at ambient temperature for 30 minutes. At the end of this period, volatiles were removed under reduced pressure to yield a crude solid. The solid was transferred to a separatory funnel using $10 \mathrm{~mL}$ water and $10 \mathrm{~mL}$ EtOAc. The layers were separated, and the aqueous layer was washed again with $10 \mathrm{~mL}$ EtOAc. The aqueous layer is then basified with $1 \mathrm{~N} \mathrm{NaOH}$ until $\mathrm{pH} 14$ (as indicated by $\mathrm{pH}$ paper). The basic layer is washed with EtOAc $(4 \times 5 \mathrm{~mL})$. The combined organic layers were washed with 10 $\mathrm{mL}$ brine, dried over $\mathrm{MgSO}_{4}$, filtered, and concentrated to a slightly yellow solid, $35.8 \mathrm{mg}, 79 \%$. The product was used in the next step and ee of the corresponding product determined to indicate enantiopurity for this step. 


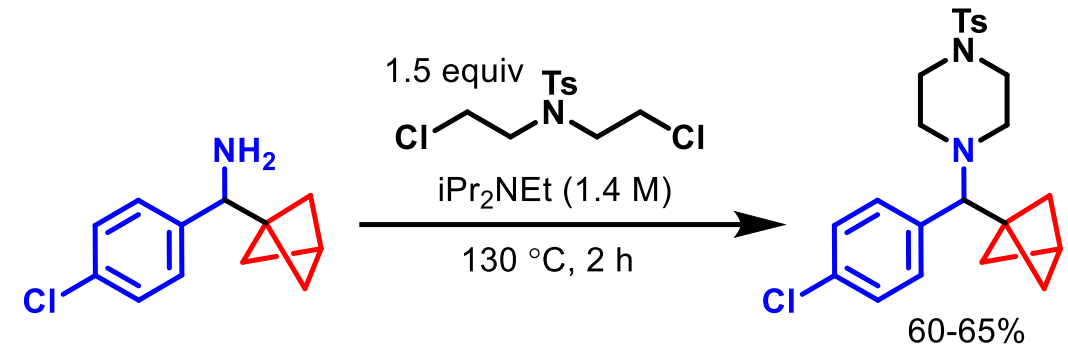

\section{1-(bicyclo[1.1.1]pentan-1-yl(4-chlorophenyl)methyl)-4-tosylpiperazine (15)}

The BCP amine (119.7 mg, $0.58 \mathrm{mmol}, 1$ equiv), N,N-bis(2-chloroethyl)-4methylbenzenesulfonamide (256.0 mg, $0.86 \mathrm{mmol}, 1.5$ equiv) and Hünig's base $(N, N$ diisopropylethylamine, $406 \mu \mathrm{L}, 1.4 \mathrm{M}$ in limiting substrate) were added to a $4 \mathrm{~mL}$ vial which was capped with a septum-lined screwcap. The reaction mixture was degassed by sparging $\mathrm{N}_{2}$ for 5 minutes. The reaction mixture was heated to $130{ }^{\circ} \mathrm{C}$ for $2 \mathrm{~h}$. The clear, yellow reaction solution gradually forms a yellow precipitate over this period. The reaction mixture is cooled to room temperature and transferred to a separatory funnel, rinsing the reaction flask with $10 \mathrm{~mL}$ water and $10 \mathrm{~mL} \mathrm{CH} \mathrm{Cl}_{2}$ to facilitate transfer. The aqueous layer was extracted twice with 10 $\mathrm{mL} \mathrm{CH}_{2} \mathrm{Cl}_{2}$. The combined organic layers are dried over $\mathrm{MgSO}_{4}$, filtered, and concentrated to a thick yellow oil. The crude material is purified by silica gel chromatography $\left(50 \% \mathrm{CH}_{2} \mathrm{Cl}_{2} /\right.$ hexanes $\rightarrow 100 \% \mathrm{CH}_{2} \mathrm{Cl}_{2}$ ) to give the product as a fluffy white solid, $150.3 \mathrm{mg}, 60 \%$. The same procedure outlined above was used for both the racemic and enantiopure materials and delivered the same yield of product after chromatography.

On a larger scale (455.7 $\mathrm{mg}$ amine, $2.20 \mathrm{mmol}$ ), a brine wash of the combined organic layers was found to be necessary before drying with $\mathrm{MgSO}_{4}$. A yield of $65 \%$ was obtained on this scale.

${ }^{1} \mathrm{H}$ NMR $\left(600 \mathrm{MHz}, \mathrm{CDCl}_{3}\right): \delta 7.63(\mathrm{~d}, J=8.2 \mathrm{~Hz}, 2 \mathrm{H}), 7.33(\mathrm{~d}, J=8.0 \mathrm{~Hz}, 2 \mathrm{H}), 7.23(\mathrm{~d}, J=8.3$ $\mathrm{Hz}, 2 \mathrm{H}), 7.06(\mathrm{~d}, J=8.3 \mathrm{~Hz}, 2 \mathrm{H}), 3.13(\mathrm{~s}, 1 \mathrm{H}), 2.96(\mathrm{t}, J=4.6 \mathrm{~Hz}, 4 \mathrm{H}), 2.66-2.62(\mathrm{~m}, 2 \mathrm{H}), 2.45-$ $2.40(\mathrm{~m}, 6 \mathrm{H})^{*}, 1.67(\mathrm{dd}, J=9.4,1.8 \mathrm{~Hz}, 3 \mathrm{H}), 1.54(\mathrm{dd}, J=9.4,1.8 \mathrm{~Hz}, 3 \mathrm{H}) \mathrm{ppm}$.

${ }^{13} \mathrm{C}\left\{{ }^{1} \mathrm{H}\right\} \mathrm{NMR}\left(125 \mathrm{MHz}, \mathrm{CDCl}_{3}\right): \delta 143.7,138.9,132.7,132.6,129.8,129.7,128.4,128.0$, 70.8, 51.1, 51.0, 47.0, 46.2, 29.2, $21.7 \mathrm{ppm}$.

HRMS calc'd for $\left[\mathrm{C}_{23} \mathrm{H}_{27} \mathrm{ClN}_{2} \mathrm{O}_{2} \mathrm{~S}+\mathrm{H}\right]^{+}=431.1560$, found 431.1568 .

*This multiplet is the overlap of three distinct signals: the $\mathrm{CH}_{3}$ of the tosyl group, the methine joining the $\mathrm{BCP}$, aromatic ring, and tertiary amine nitrogen, and $2 \mathrm{H}$ of the piperazine ring.

SFC conditions: Chiralpak OJ-3, $\mathrm{CO}_{2} / \mathrm{MeOH}(70: 30), 2.5 \mathrm{~mL} / \mathrm{min}, \Lambda=215 \mathrm{~nm}$

Racemate: 


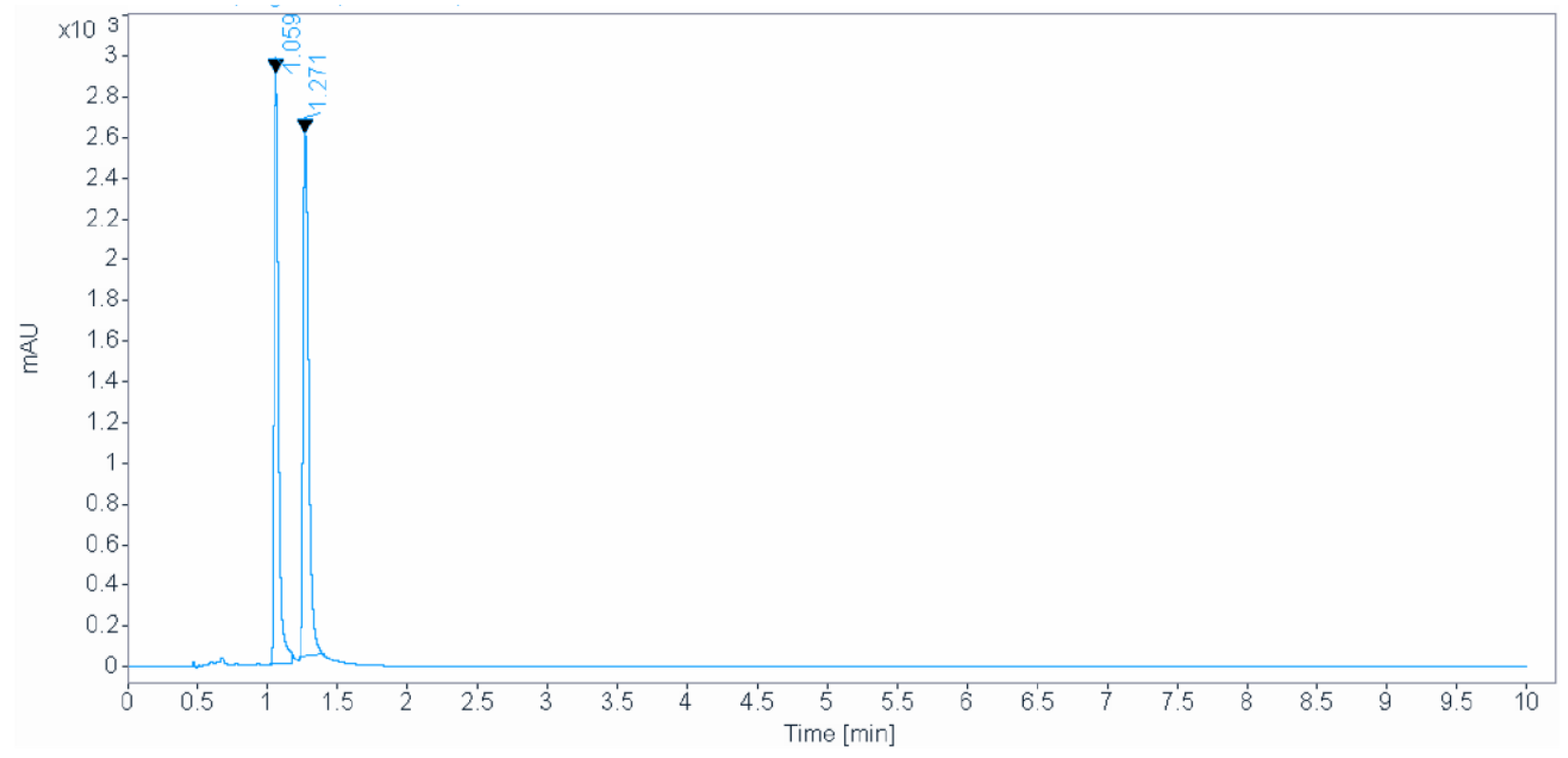

$\begin{array}{rrrrr}\text { RT [min] Type } & \text { Width [min] } & \text { Area } & \text { Height } & \text { Area\% } \\ 1.059 \mathrm{MM} & 0.0394 & 6865.7358 & 2906.5659 & 49.3755 \\ 1.271 \mathrm{MM} & 0.0457 & 7039.4155 & 2569.8735 & 50.6245\end{array}$

Enantioenriched sample:

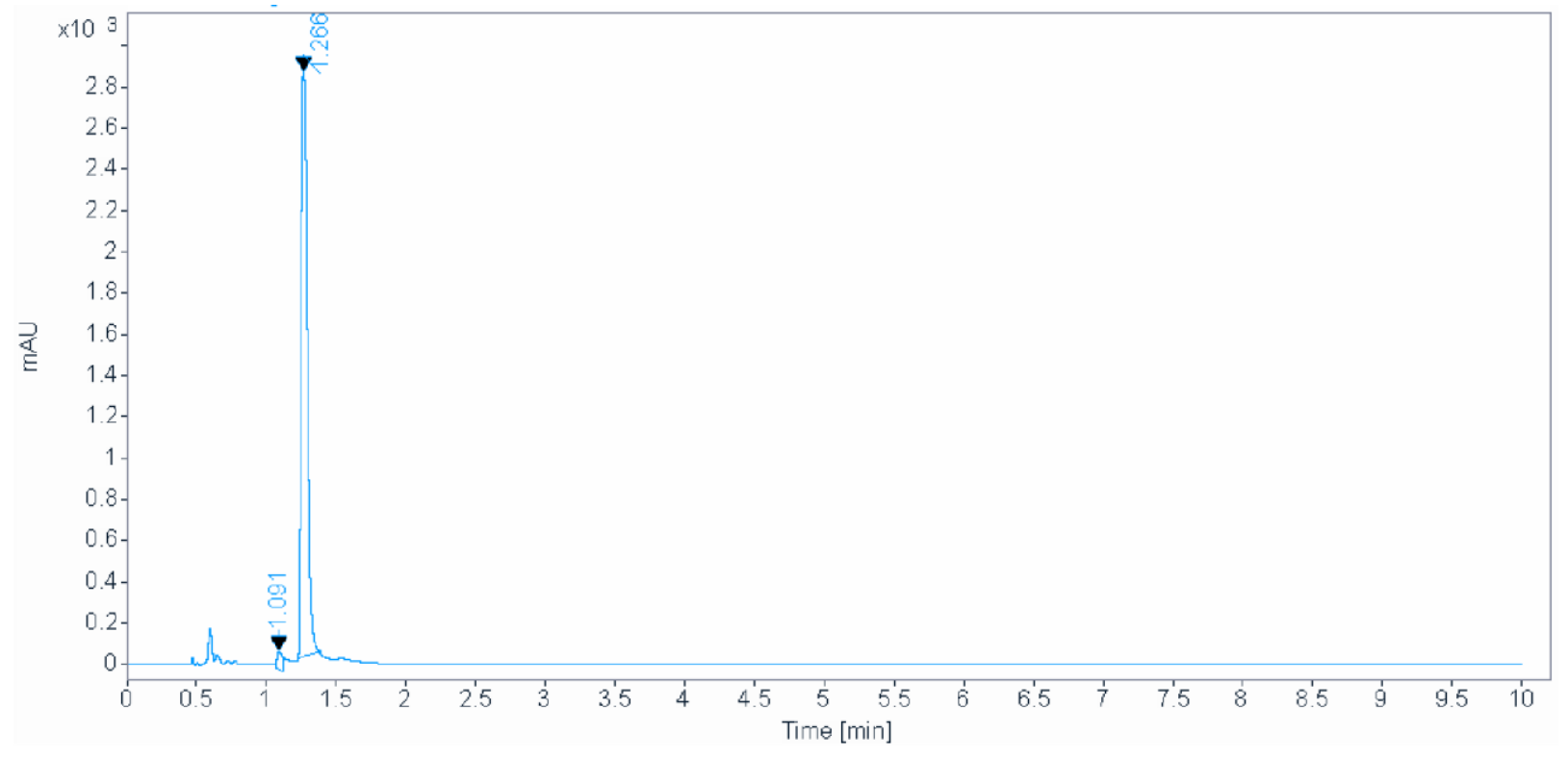

$\begin{array}{rrrrr}\text { RT [min] Type } & \text { Width [min] } & \text { Area } & \text { Height } & \text { Area\% } \\ 1.091 \mathrm{MM} & 0.0433 & 229.9899 & 88.5810 & 2.5647 \\ 1.266 \mathrm{MM} & 0.0514 & 8737.6445 & 2834.2195 & 97.4353\end{array}$




\section{Attempted optimization of MH HAT to a sulfinimine bearing an EDG}

MH HAT for electron-rich substrates (e.g. as above, 4-OMe- $\mathrm{C}_{6} \mathrm{H}_{4}$ or 3-furyl) was largely unsuccessful under the standard conditions. A 24-well plate screen of Lewis acids (Fig S2a) showed extremely little ( $<5 \%$ LCAP) product formation in most wells. To validate this screen, 4 bench-scale reactions $(0.1 \mathrm{mmol})$ and a control (no Lewis acid) were performed (Fig S2b). With no Lewis acid additive, a 37\% AY of the BCP product is observed. Lewis acid additives $\mathrm{Sc}(\mathrm{OTf})_{3}, \mathrm{AgPF}_{6}$, and $\mathrm{Zn}(\mathrm{OTf})_{2}$ gave a decrease in yield or a complete shutdown of reactivity.

A. HTE screen of Lewis acid additives for an electron-rich substrate

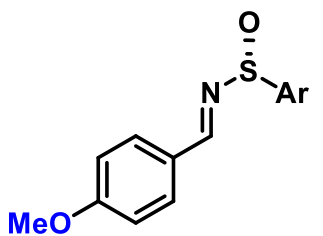

$\mathrm{Ar}=$ mesityl

(5 umol, 1 equiv.)

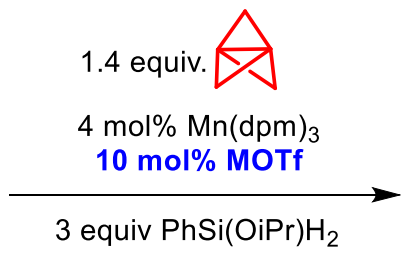

$1: 1 \mathrm{Et}_{2} \mathrm{O}: \mathrm{iPrOH}(\sim 0.23 \mathrm{M})$

$0{ }^{\circ} \mathrm{C}$ to rt, $65 \mathrm{~h}$<smiles>CC[S@@](=O)NC(c1ccc(OC)cc1)C12CC1C21CC1</smiles>

$0-5 \%$ LCAP

majority of SM remains unreacted

\begin{tabular}{|c|c|c|c|c|c|c|}
\hline & \multicolumn{6}{|c|}{ Plate Design } \\
\hline & 1 & 2 & 3 & 4 & 5 & 6 \\
\hline A & $\begin{array}{c}\mathrm{Mg}(\mathrm{OTf})_{2} \\
0.5 \text { umol }\end{array}$ & $\begin{array}{l}\mathrm{Al}(\mathrm{OTf})_{3} \\
0.5 \mathrm{umol}\end{array}$ & $\begin{array}{l}\mathrm{Ca}(\mathrm{OTf})_{2} \\
0.5 \mathrm{umol}\end{array}$ & $\begin{array}{l}\mathrm{Sc}(\mathrm{OTf})_{3} \\
0.5 \mathrm{umol}\end{array}$ & $\begin{array}{c}C p_{2} \mathrm{Ti}(\mathrm{OTf})_{2} \\
0.5 \text { umol }\end{array}$ & $\begin{array}{l}\mathrm{Fe}(\mathrm{OTf})_{2} \\
0.5 \text { umol }\end{array}$ \\
\hline B & $\begin{array}{l}\mathrm{Fe}(\mathrm{OTf})_{3} \\
0.5 \mathrm{umol}\end{array}$ & $\begin{array}{l}\mathrm{Cu}(\mathrm{OTf})_{2} \\
0.5 \mathrm{umol}\end{array}$ & $\begin{array}{l}\mathrm{Ni}(\mathrm{OTf})_{2} \\
0.5 \mathrm{umol}\end{array}$ & $\begin{array}{l}\mathrm{Zn}(\mathrm{OTf})_{2} \\
0.5 \mathrm{umol}\end{array}$ & $\begin{array}{l}\mathrm{Ga}(\mathrm{OTf})_{3} \\
0.5 \mathrm{umol}\end{array}$ & $\begin{array}{c}\mathrm{Y}(\mathrm{OTf})_{3} \\
0.5 \mathrm{umol}\end{array}$ \\
\hline C & $\begin{array}{c}\text { AgOTf } \\
0.5 \text { umol }\end{array}$ & $\begin{array}{c}\ln (\mathrm{OTf})_{3} \\
0.5 \text { umol }\end{array}$ & $\begin{array}{l}\text { Sn(OTf })_{2} \\
0.5 \text { umol }\end{array}$ & $\begin{array}{l}\mathrm{Ba}(\mathrm{OTf})_{2} \\
0.5 \text { umol }\end{array}$ & $\begin{array}{l}\mathrm{La}(\mathrm{OTf})_{3} \\
0.5 \text { umol }\end{array}$ & $\begin{array}{l}\operatorname{Pr}(\mathrm{OTf})_{3} \\
0.5 \text { umol }\end{array}$ \\
\hline D & $\begin{array}{l}\mathrm{Nd}(\mathrm{OTf})_{3} \\
0.5 \mathrm{umol}\end{array}$ & $\begin{array}{l}\mathrm{Sm}(\mathrm{OTf})_{3} \\
0.5 \mathrm{umol}\end{array}$ & $\begin{array}{l}\mathrm{Eu}(\mathrm{OTf})_{3} \\
0.5 \mathrm{umol}\end{array}$ & $\begin{array}{c}\mathrm{Er}(\mathrm{OTf})_{3} \\
0.5 \mathrm{umol}\end{array}$ & $\begin{array}{l}\mathrm{Yb}(\mathrm{OTf})_{3} \\
0.5 \mathrm{umol}\end{array}$ & $\begin{array}{c}\mathrm{Bi}(\mathrm{OTf})_{3} \\
0.5 \text { umol }\end{array}$ \\
\hline
\end{tabular}

B. $0.1 \mathrm{mmol}$ scale bench validation of HTE screen

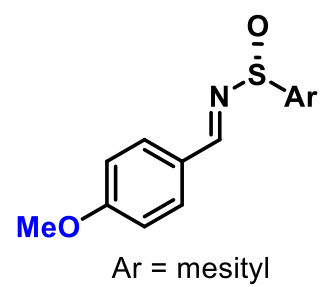

1) 1.4 equiv [1.1.1]propellane

$4 \mathrm{~mol} \% \mathrm{Mn}(\mathrm{dpm})_{3}, 10 \mathrm{~mol} \%$ LA

1:1 $\mathrm{Et}_{2} \mathrm{O}: \mathrm{iPrOH}$

2) 3 equiv $\mathrm{Ph}(\mathrm{PrO}) \mathrm{SiH}_{2}, 0^{\circ} \mathrm{C}$, $10 \mathrm{~m}$; then rt, $48 \mathrm{~h}$<smiles>COc1ccc(C(N[As](=O)[Al])C2CC2)cc1</smiles>

$\begin{array}{ll}\text { No Lewis acid: } 37 \% \text { AY } \\ \mathrm{Sc}(\mathrm{OTf})_{3} & 0 \% \text { AY } \\ \mathrm{AgPF}_{6} & 10 \% \text { AY } \\ \mathrm{Zn}(\mathrm{OTf})_{2} & 0 \% \text { AY }\end{array}$

Figure S2. HTE and bench-scale experimentation for MH HAT to an electron-rich substrate. 


\section{Attempt to prepare racemic BCP benzylamine heterocycles via 2-azaallyl anion chemistry}

As noted in the main text's discussion of reaction scope, MH HAT/propellylation to imines tolerates numerous heterocycles which were not tolerated in our previous work on 2-azaallyl anion addition to [1.1.1]propellane. ${ }^{3}$ To validate the expanded scope of MH HAT, we prepared two heterocyclic aldimines and subjected them to standard conditions for propellylation (Fig S3). No BCP products were observed for either substrate at either room temperature or $60^{\circ} \mathrm{C}$, highlighting the access of MH HAT chemistry to expanded BCP benzylamine chemical space.
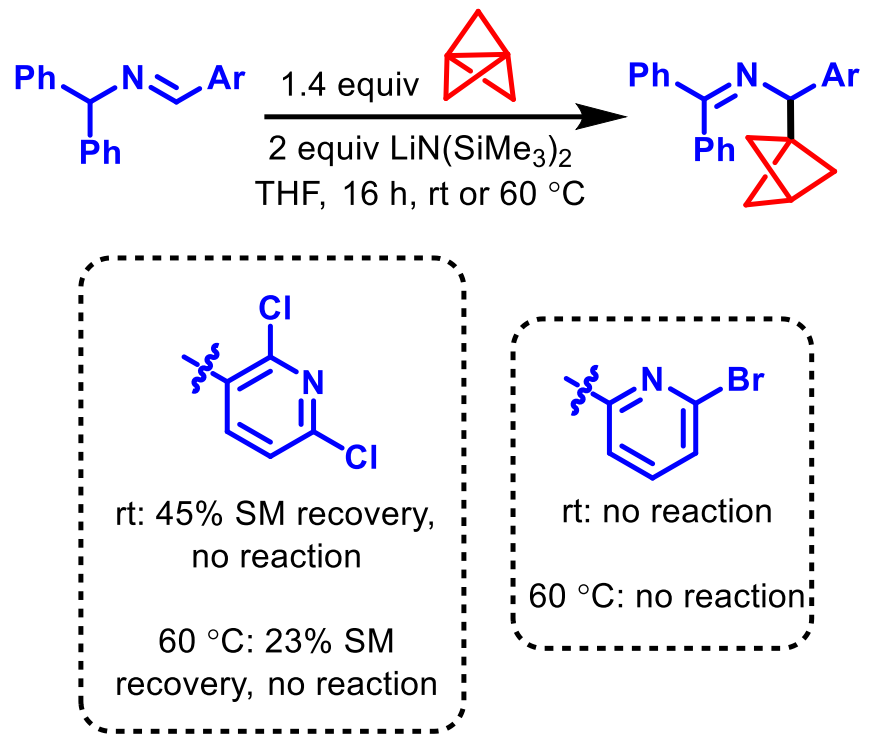

Figure S3. Attempted propellylation of heterocyclic aldimines under standard conditions of our previous work. 


\section{NMR spectra for mechanistic experiments}

Procedure for Figs. S4 and S5: In a $4 \mathrm{~mL}$ vial, a mixture of imine substrate $(0.1 \mathrm{mmol})$, $\mathrm{Mn}(\mathrm{dpm})_{3}\left(2.4 \mathrm{mg}, 0.04 \mathrm{mmol}, 4 \mathrm{~mol} \%, \mathrm{Et}_{2} \mathrm{O}(220 \mu \mathrm{L})\right.$, and $\mathrm{iPrOH}-d_{8}(220 \mu \mathrm{L})$ were combined at ambient temperature in a glovebox. The mixture was transferred to J. Young NMR tube. The silane was added gently down the side of the tube and the tube was capped. Upon mixing of the silane with the reaction mixture, vigorous bubbling and color change from dark brown to light yellow were observed. The spectrum in Fig S4 was taken at 6 hours at $\mathrm{rt}$, to ensure maximum evolution of gases and to maximize the possibility of observing $\mathrm{H}_{2} / \mathrm{HD}$, which is presumed to be poorly soluble in iPrOH- $d_{8}$. After the spectrum in Fig. S4 was acquired, the contents of the tube were subjected to three freeze-pump-thaw cycles (liquid nitrogen / high vacuum) and warmed to room temperature. The red spectrum in Fig. S5 was then obtained. The triplet was identified as $\mathrm{HD}$ based on comparison to the literature $(\delta 4.54, \mathrm{t}, J=43 \mathrm{~Hz}){ }^{4}$ A singlet at $\delta 4.57$ was also observed, which was assigned to be $\mathrm{H}_{2}$. The spectroscopic observation of $\mathrm{H}_{2}$ in our experiments was attributed to reaction of residual protio- $i \mathrm{PrOH}$ (from $i \mathrm{PrOH}-d_{8}$ ) with the metal hydride. However, it is possible the bimetallic $\mathrm{H}_{2}$ evolution mechanism ${ }^{5}$ produces the small amount of observed $\mathrm{H}_{2}$.

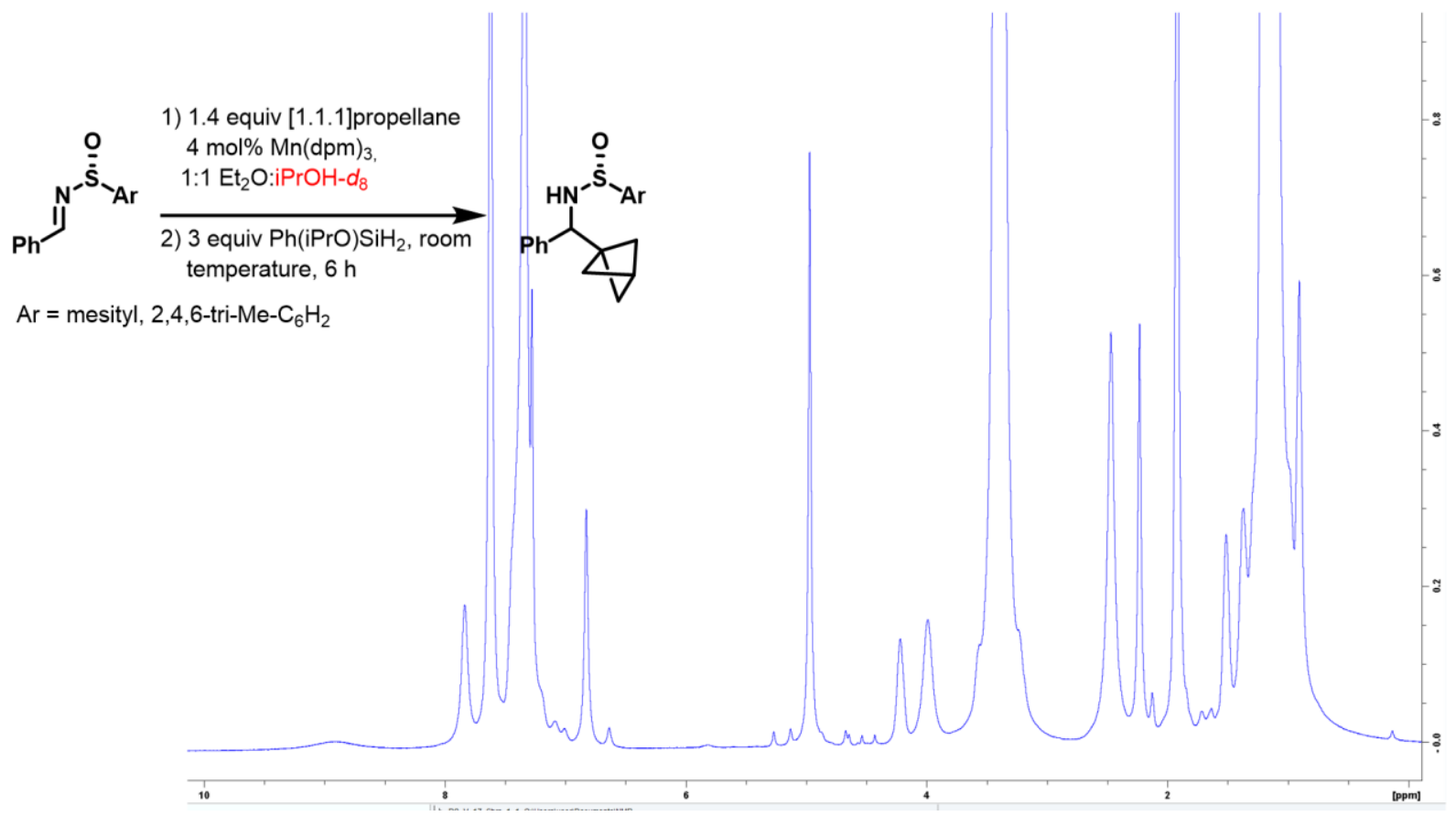

Figure S4. NMR spectrum of the reaction mixture in $\mathrm{PrOH}-d_{8}$. 


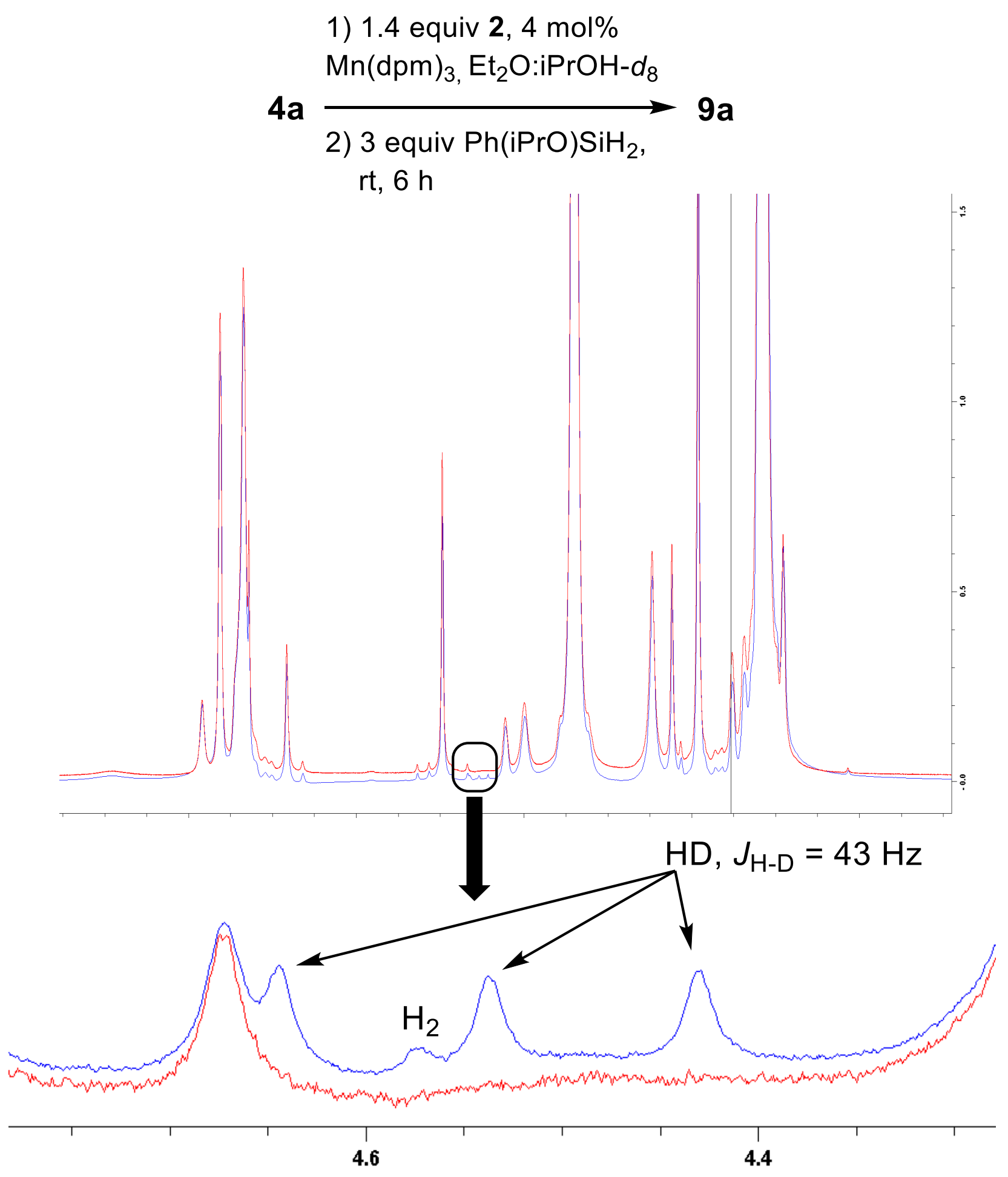

Figure S5. Top: Overlaid spectra of reaction mixture at 6 hours (blue) and the same reaction mixture following three cycles of freeze-pump-thaw (red). Bottom: $\mathrm{HD}$ triplet and $\mathrm{H}_{2}$, appearing in blue spectrum but gone after freeze-pump-thaw cycle. 
Procedure for blue spectrum: The chemical shift of $\mathrm{H}_{2}$ in $\mathrm{iPrOH}-d_{8}$ on a $400 \mathrm{MHz}$ spectrometer was determined by freezing the solvent mixture in liquid nitrogen followed by pressurization from a tank of $\mathrm{H}_{2}$ gas. The tube was capped and warmed to ambient temperature and observed by NMR.

Procedure for red spectrum: In a $4 \mathrm{~mL}$ vial, $\mathrm{Mn}(\mathrm{dpm})_{3}(2.4 \mathrm{mg})$ was dissolved in $330 \mu \mathrm{L}$ each of $\mathrm{iPrOH}-d_{8}$ and $\mathrm{Et}_{2} \mathrm{O}$. The mixture was then transferred to a J. Young tube. $\mathrm{Ph}(\mathrm{OiPr}) \mathrm{SiH}_{2}(54 \mu \mathrm{L})$ was added gently down the sides of the tube and the tube was capped. Vigorous bubbling as well as decoloration from dark brown to light yellow were observed immediately.

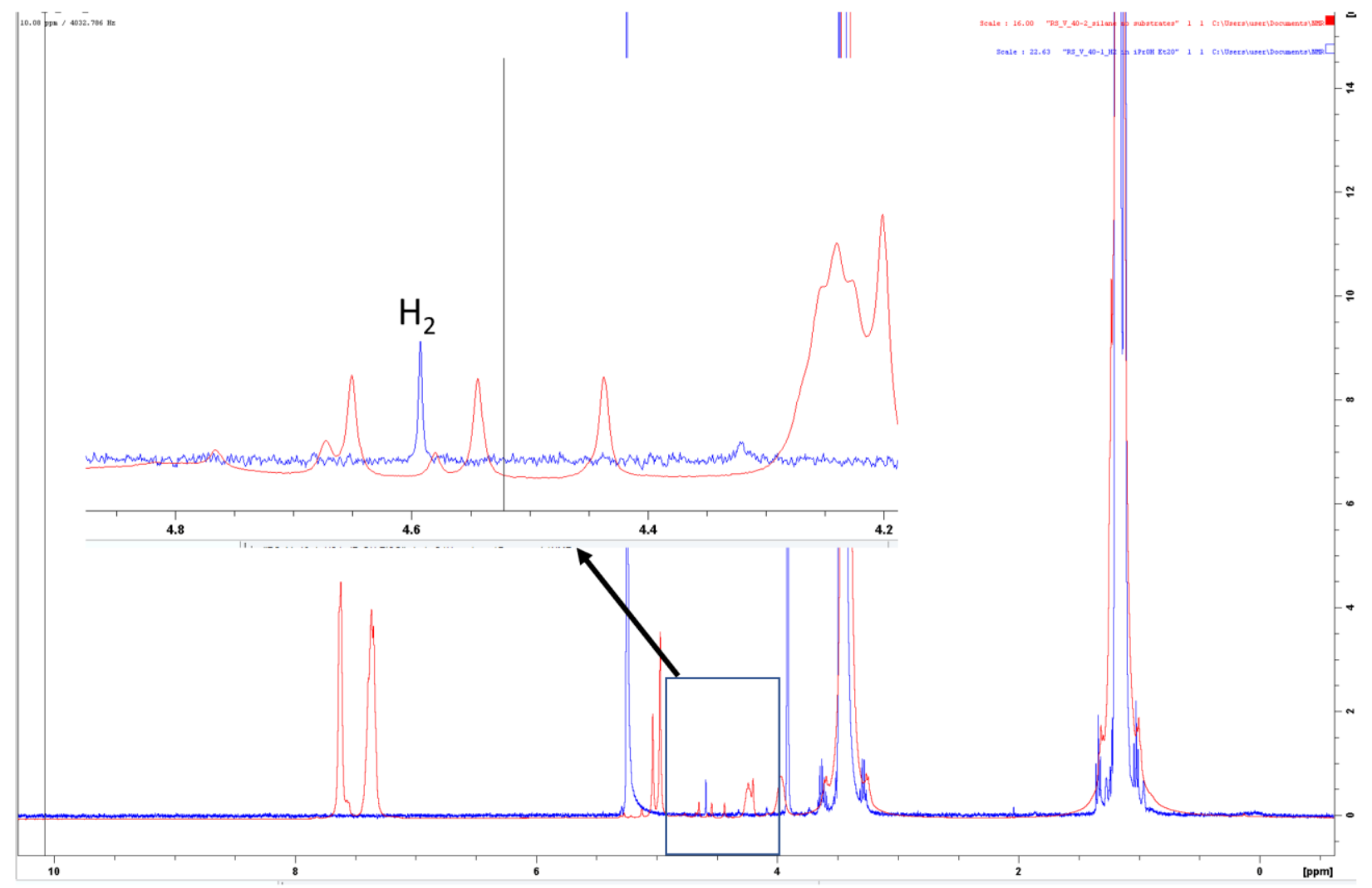

Figure S6. Confirmation of $\mathrm{H}_{2}$ chemical shift in iPrOH- $d_{8}$ and overlay with an experiment generating HD. Blue: 1 atmosphere gaseous $\mathrm{H}_{2}$ added to $330 \mu \mathrm{L}$ iPrOH- $d_{8}$ and $220 \mu \mathrm{L} \mathrm{Et}_{2} \mathrm{O}$ in a J. Young NMR tube. Red: $0.3 \mathrm{mmol} \mathrm{Ph}(\mathrm{OiPr}) \mathrm{SiH}_{2}$ added to $0.004 \mathrm{mmol} \mathrm{Mn}(\mathrm{dpm})_{3}$ dissolved in iPrOH- $d_{8}(330 \mu \mathrm{L})$ and Et2O $(220 \mu \mathrm{L})$, with no [1.1.1]propellane or imine substrates present. Inset: magnification of approx. $\delta 4.2$ to $4.9 \mathrm{ppm}$. 


\section{Gas chromatography monitoring of the reaction}

To obtain information about the silane species formed in the MH HAT reaction, we monitored the reaction by GC-MS, using either $\mathrm{PhSiH}_{3}$ or $\mathrm{Ph}(\mathrm{OiPr}) \mathrm{SiH}_{2}$ as the silane. The reaction is set up according either to General Procedure B or following General Procedure B but adding the silane dropwise at room temperature (e.g. with no ice bath chilling). At the indicated timepoints, the reaction mixture is chilled to $0{ }^{\circ} \mathrm{C}$ for 2 minutes (to minimize loss of $\mathrm{Et}_{2} \mathrm{O}$ or [1.1.1]propellane) and punctured with an inlet gas needle. An aliquot of $1 \mathrm{uL}$ is removed and diluted into $1 \mathrm{~mL}$ hexanes in an HPLC vial. The vial is analyzed promptly by GC-MS analysis.

GC chromatograms using $\mathrm{Ph}(\mathrm{OiPr}) \mathrm{SiH}_{2}$ as the silane

\section{$10 \mathrm{~m}$ after addition}

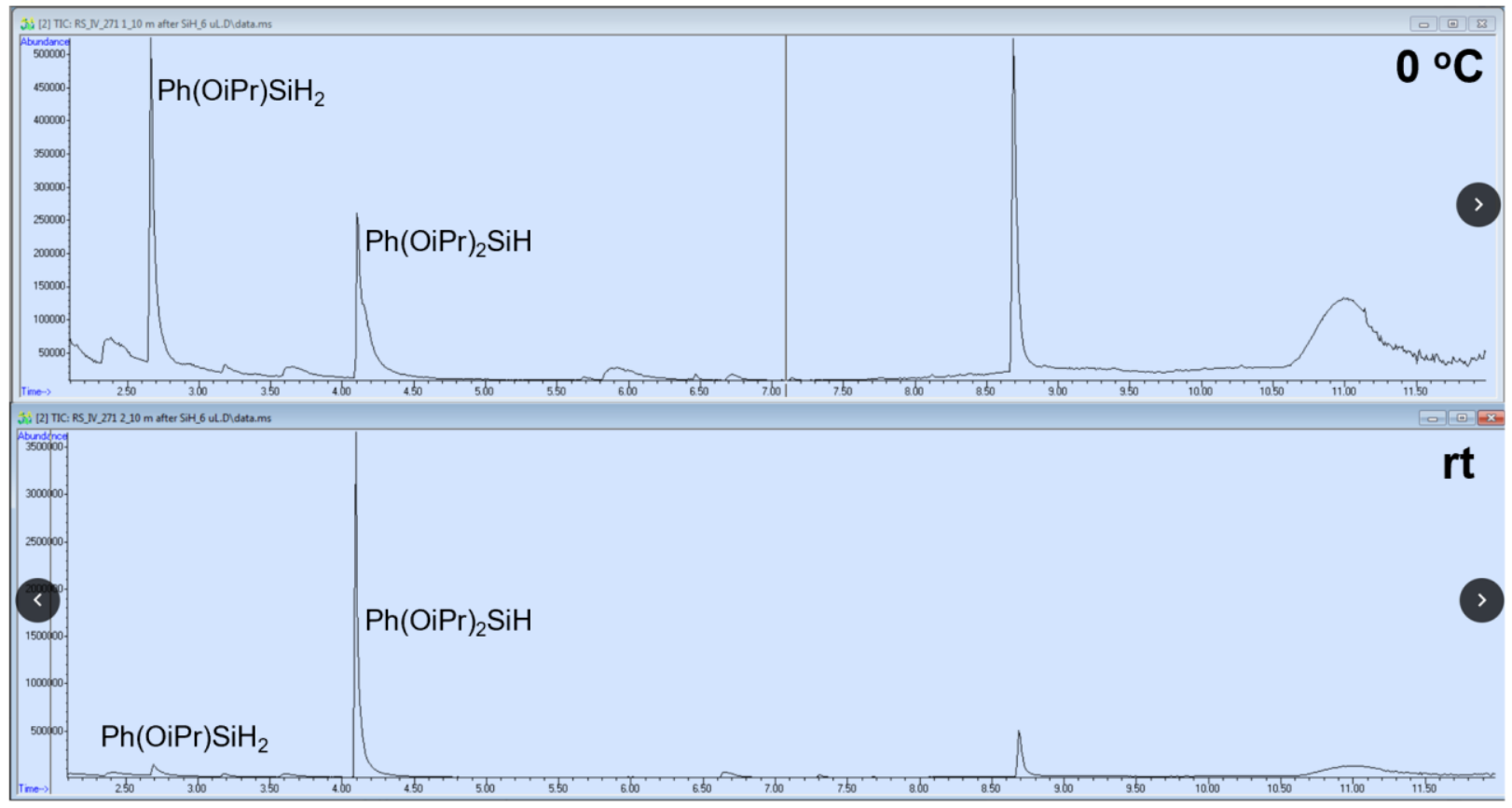

Figure S7. 


\section{$1 \mathrm{~h}$ after addition}

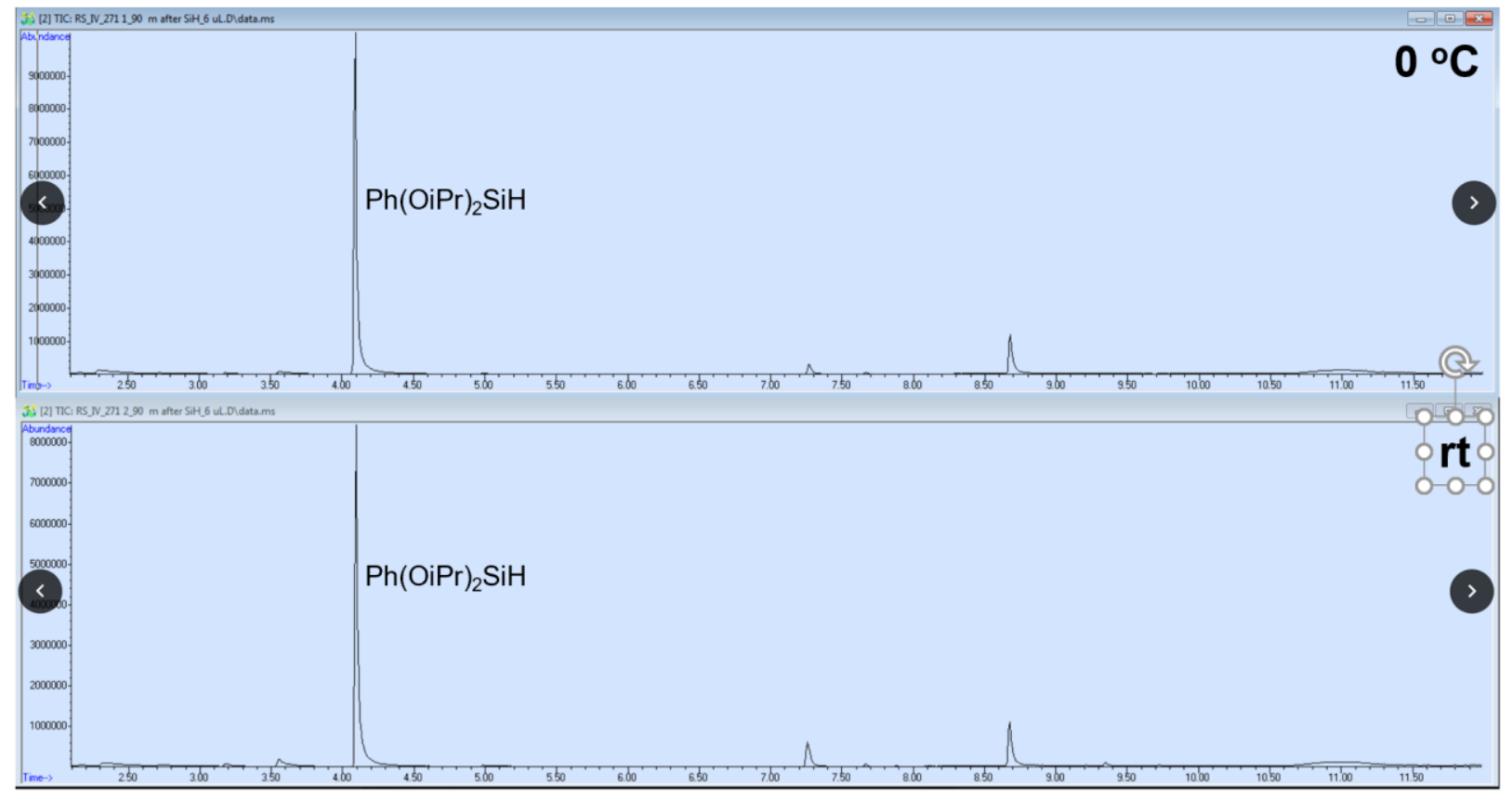

Figure S8.

\section{$4 \mathrm{~h}$ after addition}

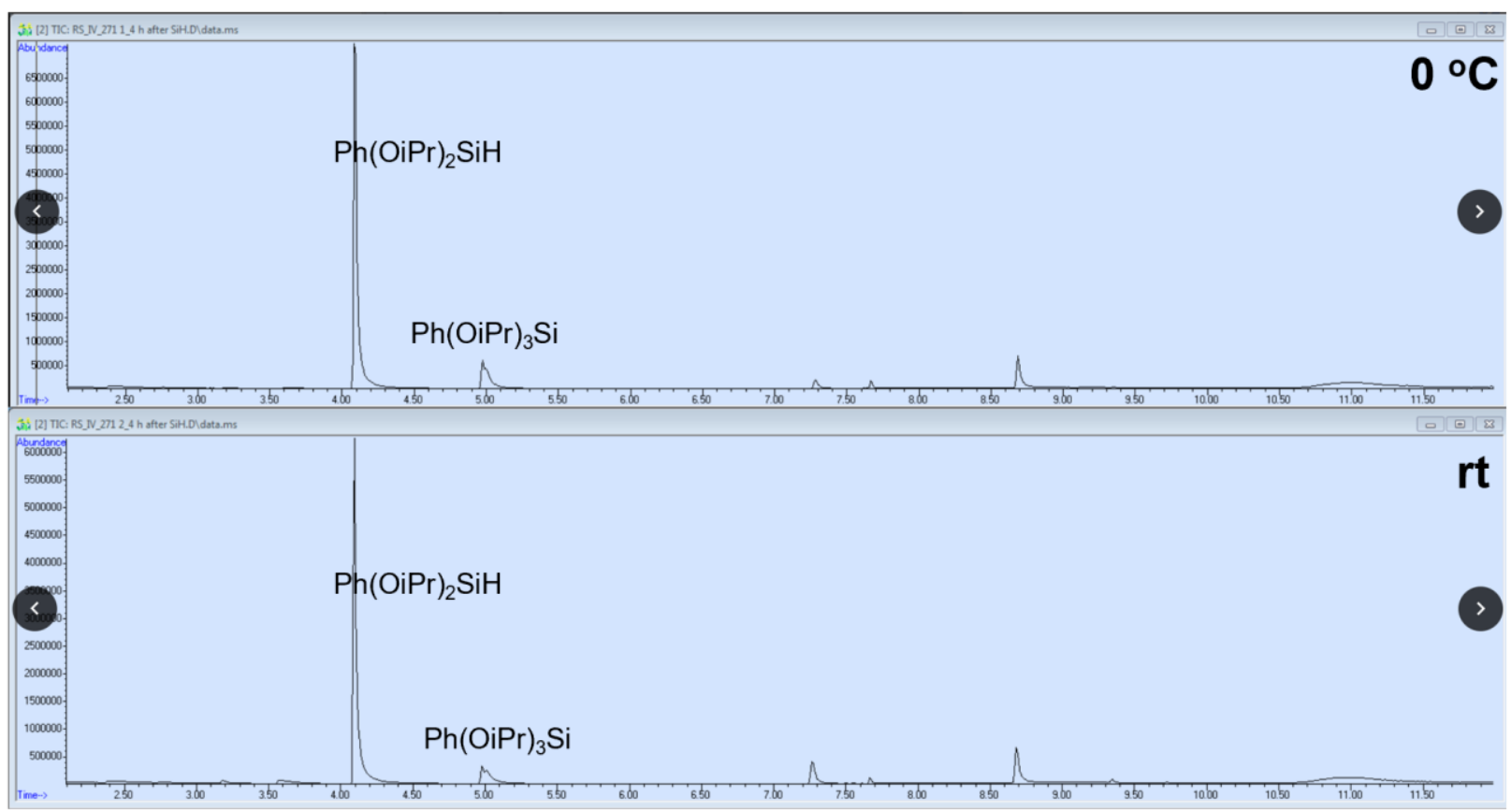

Figure S9. 


\section{$26 \mathrm{~h}$ after addition}

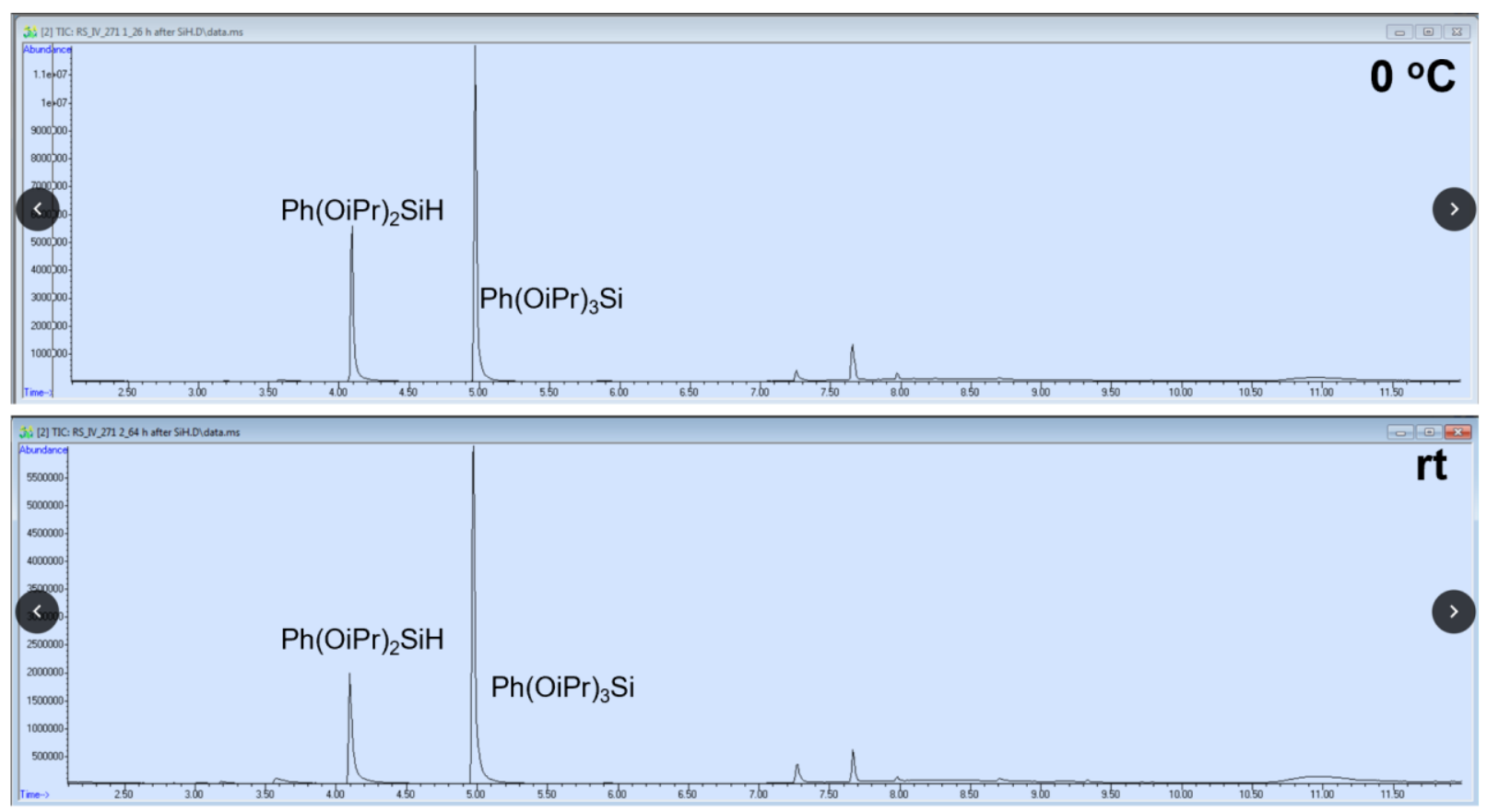

Figure S10.

Comments and conclusions of $\mathrm{Ph}(\mathrm{OiPr}) \mathrm{SiH}_{2}$ GC-MS monitoring experiment: At the 10 minute (Fig S7, top) timepoint, the reaction initiated at $0{ }^{\circ} \mathrm{C}$ still has a significant abundance of $\mathrm{Ph}(\mathrm{OiPr}) \mathrm{SiH}_{2}$ relative to $\mathrm{Ph}(\mathrm{OiPr})_{2} \mathrm{SiH}$. In contrast, initiating the reaction at room temperature results in rapid conversion of $\mathrm{Ph}(\mathrm{OiPr}) \mathrm{SiH}_{2}$ to $\mathrm{Ph}(\mathrm{OiPr})_{2} \mathrm{SiH}$. After this timepoint (from 1 to 26 $\mathrm{h}$ ), the qualitative profile of silanes formed is identical between the two reactions, eventually converting $\mathrm{Ph}(\mathrm{OiPr})_{2} \mathrm{SiH}$ into $\mathrm{Ph}(\mathrm{OiPr})_{3} \mathrm{Si}$. We hypothesize that addition of the silane at room temperature results in rapid silane consumption due to evolution of $\mathrm{H}_{2}$. This hypothesis is supported by experimental evidence (NMR of a reaction mixture in $\mathrm{iPrOH}-d_{8}$, see above) as well as the observation that room temperature-initiated reactions decolorize rapidly and produce significant bubbling at both the stir bar and solvent surface, which is presumed to be $\mathrm{H}_{2}$.

We observe $\mathrm{Ph}(\mathrm{OiPr})_{3} \mathrm{Si}$ as a silane byproduct in reactions initiated at both temperatures. However, it is not possible from GC-MS analysis to determine whether $\mathrm{Ph}(\mathrm{OiPr})_{2} \mathrm{SiH}$ converted to $\mathrm{Ph}(\mathrm{OiPr})_{3} \mathrm{Si}$ results in productive $\mathrm{MH} \mathrm{HAT} \mathrm{(i.e.} \mathrm{HAT} \mathrm{to} \mathrm{[1.1.1]propellane)} \mathrm{or} \mathrm{in} \mathrm{unproductive}$ $\mathrm{H}_{2}$ evolution. For example, it is possible that substrate $\mathrm{MH} \mathrm{HAT}$ and $\mathrm{H}_{2}$ evolution occur via two different manganese hydride species, and it is possible that $\mathrm{Ph}(\mathrm{OiPr})_{2} \mathrm{SiH}$ does not engage in hydride transfer to the MH HAT-competent species but rather to the $\mathrm{H}_{2}$-evolving species. We hypothesize that the low yield of reactions initiated at room temperature is due to rapid consumption of $\mathrm{Ph}(\mathrm{OiPr}) \mathrm{SiH}_{2}$ and conversion to $\mathrm{H}_{2}$, but it is unclear whether $\mathrm{Ph}(\mathrm{OiPr})_{2} \mathrm{SiH}$ is a competent reductant for the MH HAT transformation. 
GC chromatograms using $\mathrm{PhSiH}_{3}$ as the silane

\section{$10 \mathrm{~m}$ after addition}

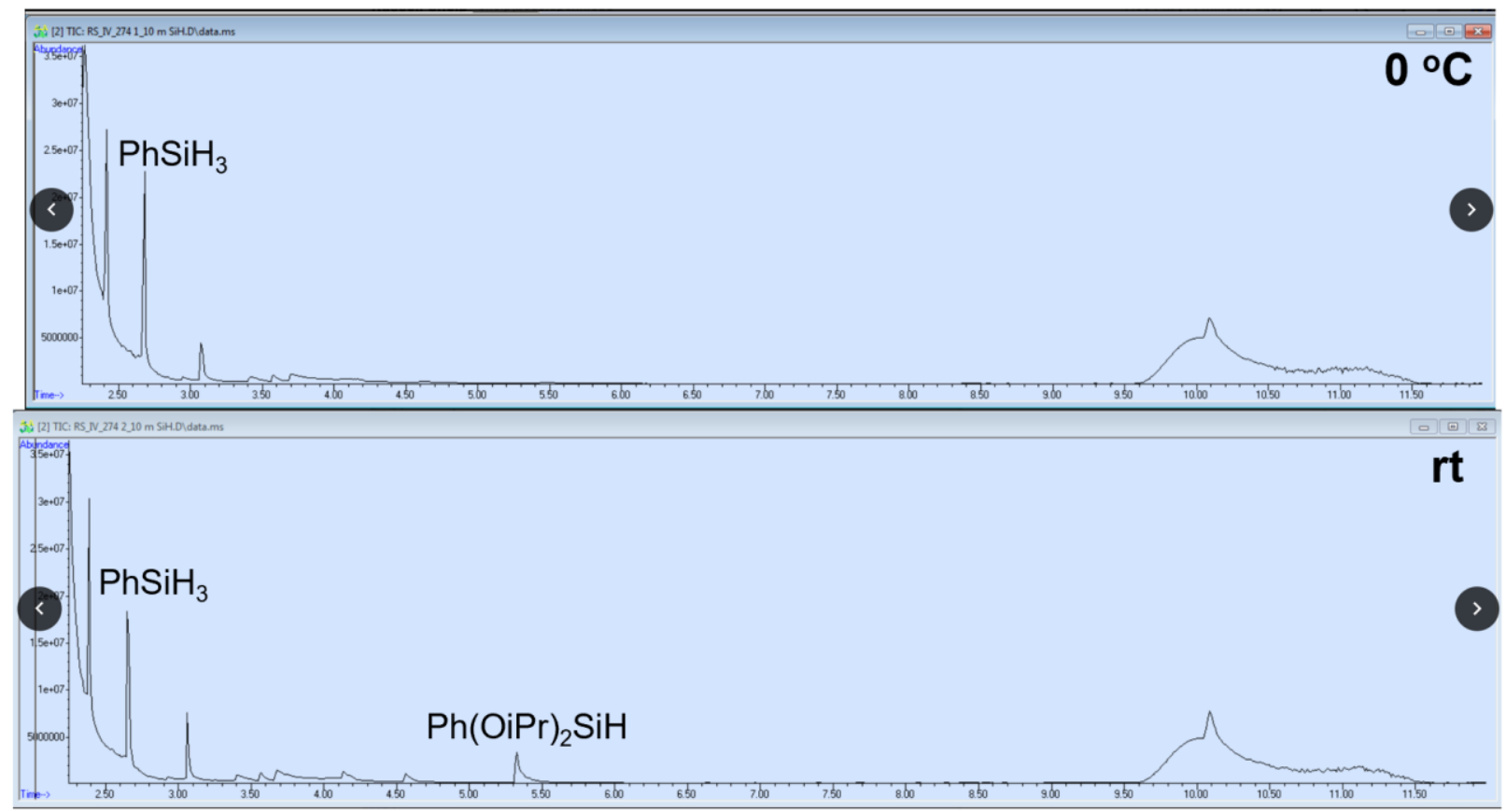

Figure S11.

\section{$1 \mathrm{~h}$ after addition}

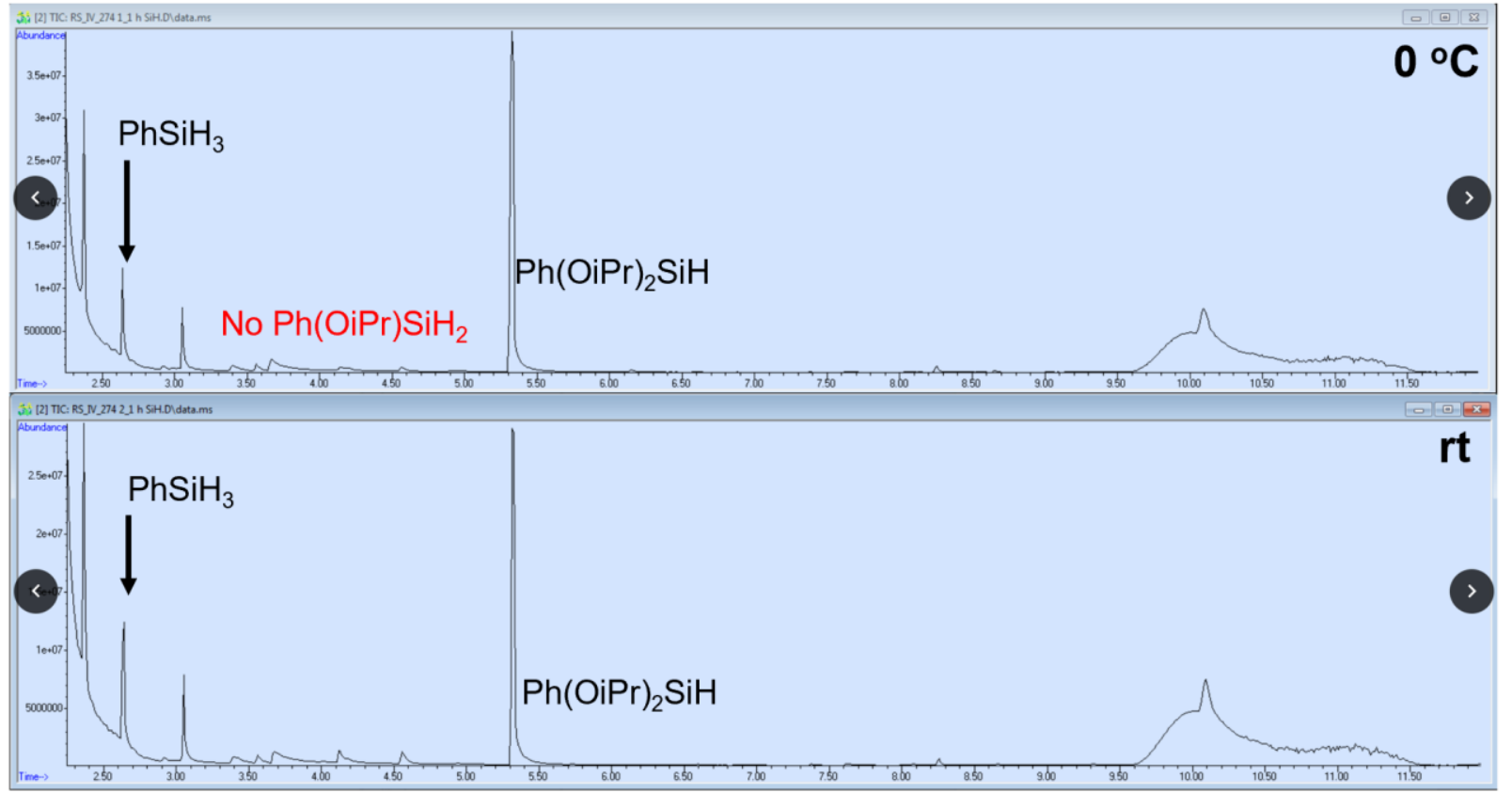

Figure S12. 


\section{$20 \mathrm{~h}$ after addition}

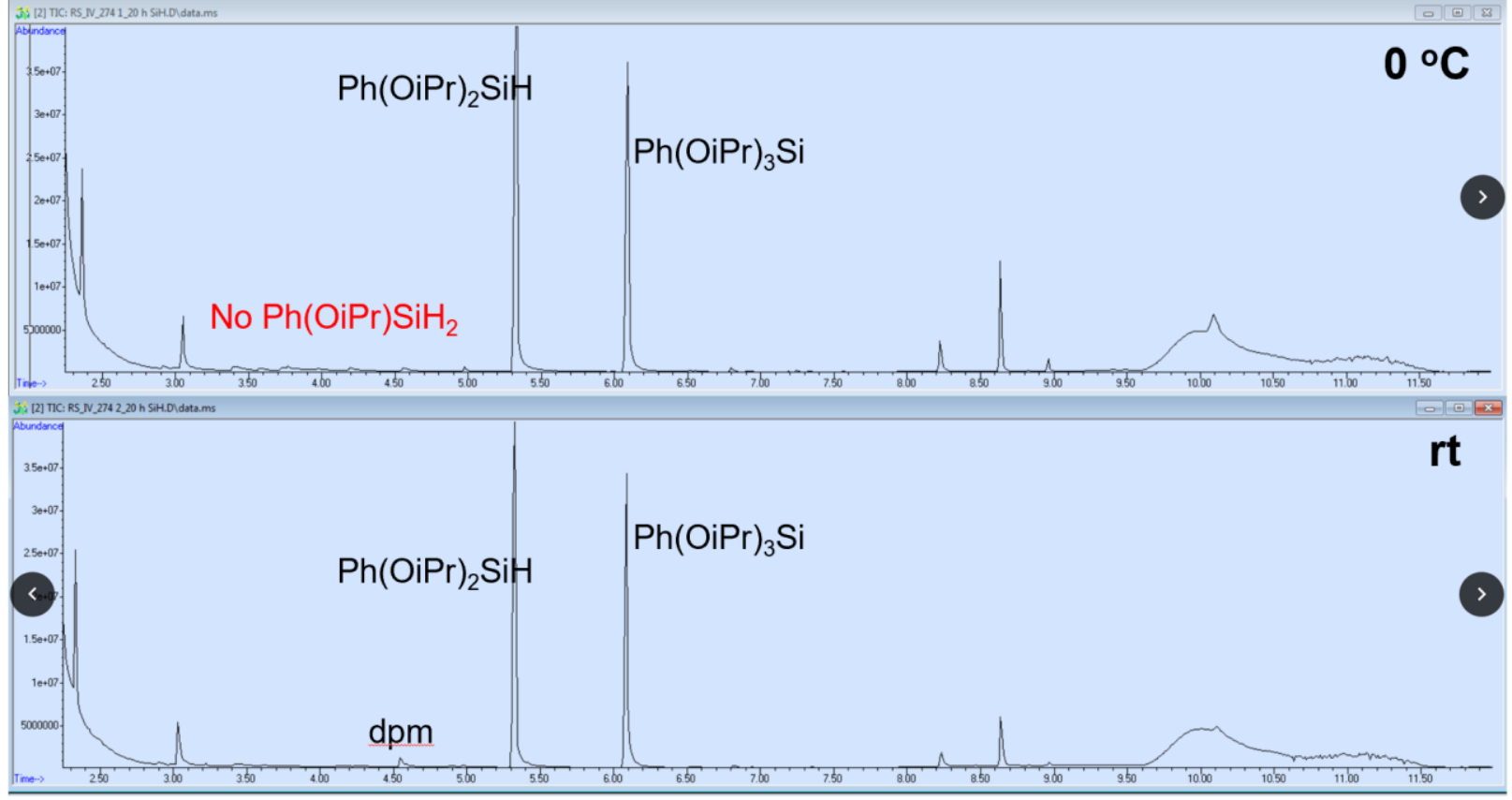

Figure S13.

Comments and conclusions of $\mathrm{PhSiH}_{3}$ GC-MS monitoring experiment: The overall silane profile is similar for room temperature or $0{ }^{\circ} \mathrm{C}$ initiation with $\mathrm{PhSiH}_{3}$ as the reductant. As in the case of $\mathrm{Ph}(\mathrm{OiPr}) \mathrm{SiH}_{2}$ above, and as expected, initiating the reaction at $0{ }^{\circ} \mathrm{C}$ results in less rapid conversion of $\mathrm{PhSiH}_{3}$ to higher order silanes. Interestingly, no $\mathrm{Ph}(\mathrm{OiPr}) \mathrm{SiH}_{2}$ is observed over the reaction period from either temperature of initiation. This observation is consistent with Shenvi's ${ }^{6}$ results that $\mathrm{Ph}(\mathrm{OiPr}) \mathrm{SiH}_{2}$ is consumed most rapidly in olefin hydrogenation, consistent with that silane's profile as a superior reductant for MH HAT chemistry.

\section{References for experimental section}

[1] Ni, S., et al., J. Am. Chem. Soc., 2019, 141, 6726-6739.

[2] Garrido-Castro, A.F., Choubane, H., Daaou, M., Carmen Maestro, M. Aleman, J., Chem. Comm., 2017, 53, 7764-7767.

[3] Shelp, R.A. and Walsh, P.J., Angew. Chem. Int. Ed. 2018, 57, 15857 -15861 222

[4] Planellas, M.; Guo, W.; Alonso, F.; Yus, M.; Shafir, A.; Pleixats, R.; Parella, T.

Hydrosilylation of Internal Alkynes Catalyzed by Tris- Imidazolium Salt-Stabilized Palladium Nanoparticles. Adv. Synth. Catal. 2014, 356, 179-188. 
[5] Green, S.A.; Crossley, S.W.M; Matos, J.L.M.; Vásquez-Céspedes, S.; Shevick, S.L.; Shenvi, R.A. The High Chemofidelity of Metal-Catalyzed Hydrogen Atom Transfer. Acc. Chem. Res. 2018, 51, 2628-2640.

[6] Obradors, C., Martinez, R.M., and Shenvi, R.A. J. Am. Chem. Soc. 2016, 138, 4962-4971.

\section{X-ray Structure Determination of Compound 6246}

Procedure for crystallization: The $\mathrm{BCP}$ sulfinamide is dissolved in a generous quantity of $\mathrm{Et}_{2} \mathrm{O}$ in a $4 \mathrm{~mL}$ vial. The vial is capped and chilled to $-15^{\circ} \mathrm{C}$ for $1 \mathrm{~h}$. The vial is then uncapped and put into a $20 \mathrm{~mL}$ vial which contains a generous quantity of $n$-pentane. The $20 \mathrm{~mL}$ vial is capped and the mixture placed in the freezer. After slow evaporation of the $\mathrm{Et}_{2} \mathrm{O}$ layer into the $n$-pentane layer overnight, square, clear, yellow crystals are formed. The same procedure is used for the opposite enantiomer below (Compound 6248).
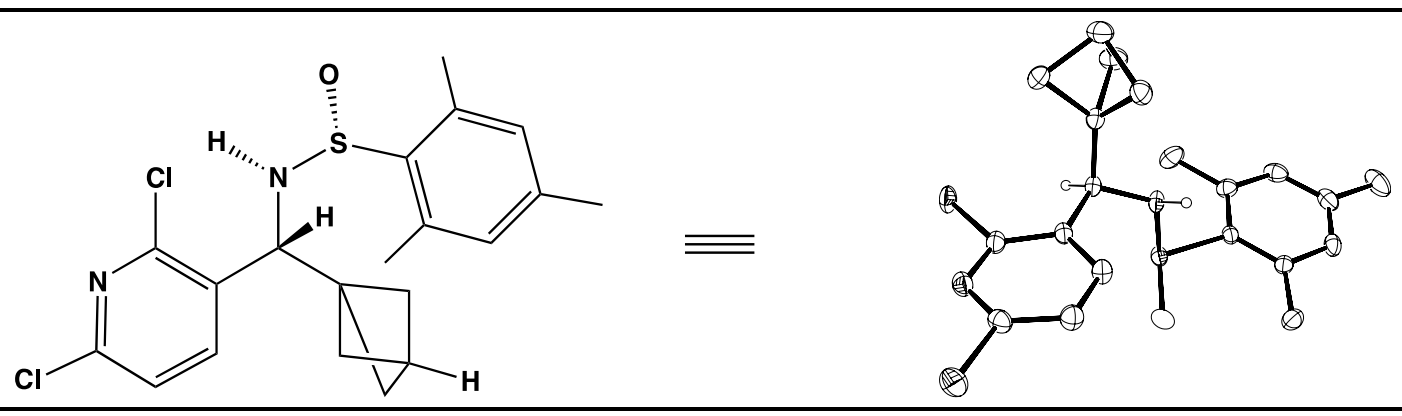

Compound 6246, $\mathrm{C}_{20} \mathrm{H}_{22} \mathrm{Cl}_{2} \mathrm{~N}_{2} \mathrm{OS}$, crystallizes in the orthorhombic space group $\mathrm{P} 2{ }_{1}{ }_{1}{ }_{1}{ }_{1}$ (systematic absences h00: h=odd, 0k0: k=odd, and 001: l=odd) with $\mathrm{a}=13.36310(10) \AA$, $\mathrm{b}=13.9939(2) \AA, c=21.3244(2) \AA, \mathrm{V}=3987.70(7) \AA^{3}, \mathrm{Z}=8$, and $\mathrm{d}_{\mathrm{calc}}=1.364 \mathrm{~g} / \mathrm{cm}^{3}$. X-ray intensity data were collected on a Rigaku XtaLAB Synergy-S diffractometer [1] equipped with an HPC area detector (Dectris Pilatus3 R 200K) and employing confocal multilayer optic-monochromated Mo$\mathrm{K} \alpha$ radiation $(\lambda=0.71073 \AA)$ at a temperature of $100 \mathrm{~K}$. Preliminary indexing was performed from a series of thirty $0.5^{\circ}$ rotation frames with exposures of 0.625 seconds. A total of 3414 frames (26 runs) were collected employing $\omega$ scans with a crystal to detector distance of $34.0 \mathrm{~mm}$, rotation widths of $0.5^{\circ}$ and exposures of 6 seconds.

Rotation frames were integrated using CrysAlisPro [2], producing a listing of unaveraged $\mathrm{F}^{2}$ and $\sigma\left(\mathrm{F}^{2}\right)$ values. A total of 235878 reflections were measured over the ranges $4.628 \leq 2 \theta \leq$ $56.558^{\circ},-17 \leq \mathrm{h} \leq 17,-18 \leq \mathrm{k} \leq 18,-28 \leq 1 \leq 28$ yielding 9897 unique reflections $\left(\mathrm{R}_{\mathrm{int}}=0.0485\right)$. 
The intensity data were corrected for Lorentz and polarization effects and for absorption using SCALE3 ABSPACK [3] (minimum and maximum transmission 0.6613, 1.0000). The structure was solved by direct methods - SHELXT [4]. Refinement was by full-matrix least squares based on $\mathrm{F}^{2}$ using SHELXL-2018 [5]. All reflections were used during refinement. The weighting scheme used was $\mathrm{w}=1 /\left[\sigma^{2}\left(\mathrm{~F}_{\mathrm{o}}{ }^{2}\right)+(0.0423 \mathrm{P})^{2}+0.6886 \mathrm{P}\right]$ where $\mathrm{P}=\left(\mathrm{F}_{\mathrm{o}}{ }^{2}+2 \mathrm{~F}_{\mathrm{c}}{ }^{2}\right) / 3$. Non-hydrogen atoms were refined anisotropically and hydrogen atoms were refined using a riding model. Refinement converged to $\mathrm{R} 1=0.0231$ and $w \mathrm{R} 2=0.0625$ for 9665 observed reflections for which $\mathrm{F}$ $>4 \sigma(\mathrm{F})$ and $\mathrm{R} 1=0.0240$ and $\mathrm{wR} 2=0.0664$ and $\mathrm{GOF}=1.076$ for all 9897 unique, non-zero reflections and 481 variables. The maximum $\Delta / \sigma$ in the final cycle of least squares was 0.001 and the two most prominent peaks in the final difference Fourier were +0.35 and $-0.21 \mathrm{e} / \AA^{3}$. The Hooft absolute structure parameter y [6] was calculated using PLATON [7] The resulting value was $y=$ $-0.012(6)$ indicating that the absolute structure has been assigned correctly. The Flack parameter [8] refined to a similar value of $-0.011(7)$. If these parameters are equal to 0 (within 3 standard deviations) then the absolute structure has been assigned correctly; if they are 1, the opposite enantiomer has been modeled.

Table 1. lists cell information, data collection parameters, and refinement data. Final positional and equivalent isotropic thermal parameters are given in Tables 2. and 3. Anisotropic thermal parameters are in Table 4. Tables 5. and 6. list bond distances and bond angles. Figure 1. is an ORTEP representation of the molecule with 50\% probability thermal ellipsoids displayed. 


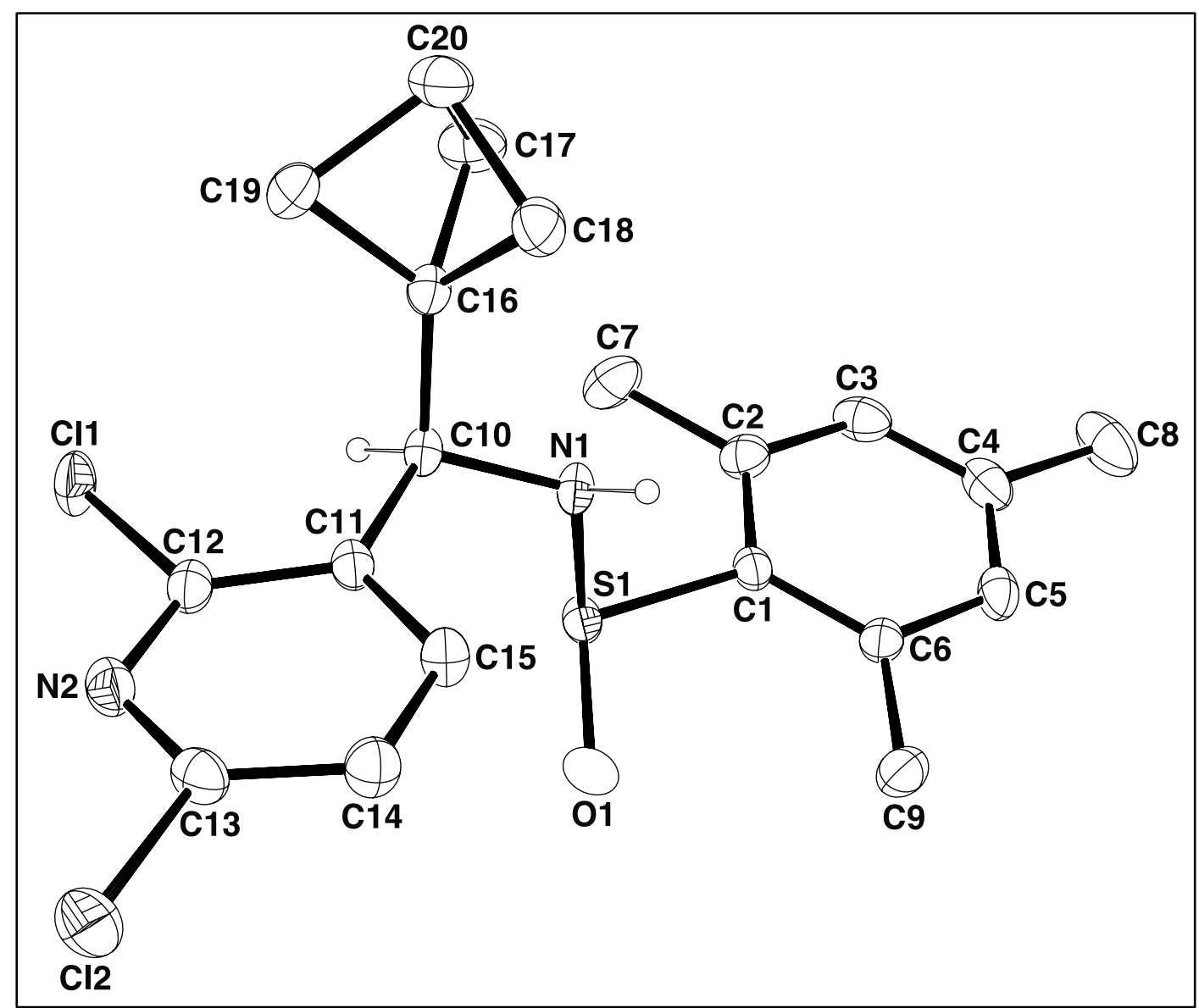

Figure S14. ORTEP drawing of the title compound with 50\% thermal ellipsoids. 
Table S2. Summary of Structure Determination of Compound 6246

\begin{tabular}{|c|c|}
\hline Empirical formula & $\mathrm{C}_{20} \mathrm{H}_{22} \mathrm{Cl}_{2} \mathrm{~N}_{2} \mathrm{OS}$ \\
\hline Formula weight & 409.35 \\
\hline Diffractometer & Rigaku XtaLAB Synergy-S (Dectris Pilatus3 R 200K) \\
\hline Temperature/K & 100 \\
\hline Crystal system & orthorhombic \\
\hline Space group & $\mathrm{P} 2{ }_{1}{ }_{1} 2_{1}$ \\
\hline a & $13.36310(10) \AA$ \\
\hline b & 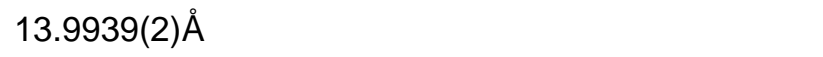 \\
\hline c & $21.3244(2) \AA$ \\
\hline Volume & $3987.70(7) \AA^{3}$ \\
\hline Z & 8 \\
\hline$d_{\text {calc }}$ & $1.364 \mathrm{~g} / \mathrm{cm}^{3}$ \\
\hline$\mu$ & $0.442 \mathrm{~mm}^{-1}$ \\
\hline$F(000)$ & 1712.0 \\
\hline Crystal size, mm & $0.25 \times 0.2 \times 0.12$ \\
\hline $2 \theta$ range for data collection & $4.628-56.558^{\circ}$ \\
\hline Index ranges & $-17 \leq \mathrm{h} \leq 17,-18 \leq \mathrm{k} \leq 18,-28 \leq \mathrm{I} \leq 28$ \\
\hline Reflections collected & 235878 \\
\hline Independent reflections & $9897[R($ int $)=0.0485]$ \\
\hline Data/restraints/parameters & $9897 / 2 / 481$ \\
\hline Goodness-of-fit on $\mathrm{F}^{2}$ & 1.076 \\
\hline Final $R$ indexes $[\mid>=2 \sigma(I)]$ & $\mathrm{R}_{1}=0.0231, \mathrm{wR}_{2}=0.0625$ \\
\hline Final $R$ indexes [all data] & $\mathrm{R}_{1}=0.0240, \mathrm{wR}_{2}=0.0664$ \\
\hline Largest diff. peak/hole & $0.35 /-0.21 \mathrm{e}^{-3}$ \\
\hline Flack parameter & $-0.011(7)$ \\
\hline Hooft parameter & $-0.012(6)$ \\
\hline
\end{tabular}


Table S3. Refined Positional Parameters for Compound 6246

\begin{tabular}{|c|c|c|c|c|}
\hline Atom & $x$ & $y$ & $z$ & $U(e q)$ \\
\hline $\mathrm{Cl} 1$ & $0.37360(4)$ & $1.01530(3)$ & $0.38726(2)$ & $0.02564(10)$ \\
\hline $\mathrm{Cl} 2$ & $0.01337(4)$ & $0.91263(4)$ & $0.32758(3)$ & $0.03151(11)$ \\
\hline S1 & $0.50588(3)$ & $0.71120(3)$ & $0.29888(2)$ & $0.01805(9)$ \\
\hline 01 & $0.42206(11)$ & $0.69164(11)$ & $0.25495(6)$ & $0.0265(3)$ \\
\hline N1 & $0.46974(11)$ & $0.71193(10)$ & $0.37383(7)$ & $0.0175(3)$ \\
\hline $\mathrm{N} 2$ & $0.19909(12)$ & $0.94804(11)$ & $0.35753(7)$ & $0.0222(3)$ \\
\hline C1 & $0.58400(13)$ & $0.60671(12)$ & $0.30546(8)$ & $0.0172(3)$ \\
\hline $\mathrm{C} 2$ & $0.68005(14)$ & $0.62431(14)$ & $0.33027(9)$ & $0.0224(4)$ \\
\hline C3 & $0.74729(15)$ & $0.54879(16)$ & $0.33381(9)$ & $0.0262(4)$ \\
\hline C4 & $0.72265(16)$ & $0.45745(15)$ & $0.31351(9)$ & $0.0269(4)$ \\
\hline C5 & $0.62718(16)$ & $0.44202(13)$ & $0.28954(8)$ & $0.0243(4)$ \\
\hline C6 & $0.55608(14)$ & $0.51554(13)$ & $0.28482(8)$ & $0.0190(3)$ \\
\hline $\mathrm{C7}$ & $0.71140(16)$ & $0.72246(16)$ & $0.35271(11)$ & $0.0312(4)$ \\
\hline C8 & $0.7974(2)$ & $0.37690(19)$ & $0.31648(11)$ & $0.0416(6)$ \\
\hline C9 & $0.45534(15)$ & $0.49134(14)$ & $0.25697(9)$ & $0.0252(4)$ \\
\hline C10 & $0.43208(13)$ & $0.80379(12)$ & $0.39720(8)$ & $0.0169(3)$ \\
\hline C11 & $0.32545(13)$ & $0.82777(12)$ & $0.37751(8)$ & $0.0171(3)$ \\
\hline C12 & $0.29148(14)$ & $0.92167(13)$ & $0.37272(8)$ & $0.0195(3)$ \\
\hline C13 & $0.13498(14)$ & $0.87846(14)$ & $0.34647(9)$ & $0.0225(4)$ \\
\hline C14 & $0.15773(14)$ & $0.78172(14)$ & $0.34897(9)$ & $0.0234(4)$ \\
\hline C15 & $0.25504(14)$ & $0.75711(13)$ & $0.36459(9)$ & $0.0215(4)$ \\
\hline C16 & $0.44026(13)$ & $0.80163(13)$ & $0.46808(8)$ & $0.0185(3)$ \\
\hline C17 & $0.53779(15)$ & $0.79188(17)$ & $0.50768(9)$ & $0.0293(4)$ \\
\hline C18 & $0.39293(16)$ & $0.72578(14)$ & $0.51206(9)$ & $0.0250(4)$ \\
\hline C19 & $0.40504(16)$ & $0.87838(14)$ & $0.51622(9)$ & $0.0258(4)$ \\
\hline $\mathrm{C} 20$ & $0.45025(15)$ & $0.79587(16)$ & $0.55567(9)$ & $0.0265(4)$ \\
\hline $\mathrm{Cl} 1^{\prime}$ & $0.01918(3)$ & $0.36019(3)$ & $0.47572(3)$ & $0.02918(11)$ \\
\hline $\mathrm{Cl} 2^{\prime}$ & $0.07783(4)$ & $-0.00519(3)$ & $0.50007(3)$ & $0.03311(12)$ \\
\hline$S 1^{\prime}$ & $0.36799(3)$ & $0.44679(3)$ & $0.40572(2)$ & $0.01744(9)$ \\
\hline $01^{\prime}$ & $0.33433(11)$ & $0.54844(9)$ & $0.40542(7)$ & $0.0234(3)$ \\
\hline $\mathrm{N} 1^{\prime}$ & $0.34551(11)$ & $0.39622(11)$ & $0.47405(7)$ & $0.0184(3)$ \\
\hline N2' & $0.06577(12)$ & $0.18029(12)$ & $0.48823(8)$ & $0.0231(3)$ \\
\hline C1' & $0.27787(13)$ & $0.37793(13)$ & $0.36187(8)$ & $0.0184(3)$ \\
\hline $\mathrm{C} 2^{\prime}$ & $0.18204(15)$ & $0.40998(13)$ & $0.34455(9)$ & $0.0223(4)$ \\
\hline C3' & $0.11851(15)$ & $0.34373(15)$ & $0.31585(9)$ & $0.0261(4)$ \\
\hline C4' & $0.14709(16)$ & $0.25016(14)$ & $0.30327(9)$ & $0.0256(4)$ \\
\hline C5' & $0.24422(15)$ & $0.22265(14)$ & $0.31776(9)$ & $0.0232(4)$ \\
\hline C6' & $0.31105(14)$ & $0.28495(13)$ & $0.34679(8)$ & $0.0192(3)$ \\
\hline $\mathrm{C7}^{\prime}$ & $0.14289(17)$ & $0.51066(15)$ & $0.35308(11)$ & $0.0313(4)$ \\
\hline
\end{tabular}




\begin{tabular}{|lllll} 
C8' & $0.07424(18)$ & $0.18081(16)$ & $0.27395(12)$ & $0.0355(5)$ \\
$C^{\prime}$ & $0.41571(14)$ & $0.25067(13)$ & $0.36213(9)$ & $0.0230(4)$ \\
$C 10^{\prime}$ & $0.24552(12)$ & $0.39167(13)$ & $0.50207(8)$ & $0.0169(3)$ \\
$C 111^{\prime}$ & $0.20475(12)$ & $0.29029(13)$ & $0.49949(8)$ & $0.0175(3)$ \\
$C 12^{\prime}$ & $0.10440(13)$ & $0.26803(13)$ & $0.48887(9)$ & $0.0200(3)$ \\
$C 13^{\prime}$ & $0.12888(14)$ & $0.10924(13)$ & $0.49976(9)$ & $0.0236(4)$ \\
$C 14^{\prime}$ & $0.23000(14)$ & $0.12057(14)$ & $0.51122(10)$ & $0.0244(4)$ \\
$C 15^{\prime}$ & $0.26727(13)$ & $0.21260(14)$ & $0.51087(9)$ & $0.0217(4)$ \\
$C 16^{\prime}$ & $0.24957(14)$ & $0.42633(14)$ & $0.56929(9)$ & $0.0207(3)$ \\
$C 177^{\prime}$ & $0.27167(18)$ & $0.53041(15)$ & $0.59086(10)$ & $0.0320(4)$ \\
$C 18^{\prime}$ & $0.32156(18)$ & $0.39333(16)$ & $0.62227(10)$ & $0.0318(4)$ \\
$C 19^{\prime}$ & $0.16405(19)$ & $0.4244(2)$ & $0.61817(11)$ & $0.0422(6)$ \\
$C 20^{\prime}$ & $0.25426(18)$ & $0.47197(18)$ & $0.65167(10)$ & $0.0347(5)$ \\
\hline
\end{tabular}


Table S4. Positional Parameters for Hydrogens in Compound 6246

\begin{tabular}{|c|c|c|c|c|}
\hline Atom & $x$ & $y$ & $z$ & $\mathrm{U}(\mathrm{eq})$ \\
\hline $\mathrm{H} 1$ & $0.4359(17)$ & $0.6614(15)$ & $0.3865(11)$ & 0.021 \\
\hline H3 & 0.812077 & 0.55995 & 0.350617 & 0.031 \\
\hline H5 & 0.609491 & 0.379633 & 0.275909 & 0.029 \\
\hline $\mathrm{H} 7 \mathrm{a}$ & 0.670826 & 0.7407 & 0.389074 & 0.047 \\
\hline $\mathrm{H} 7 \mathrm{~b}$ & 0.701459 & 0.76901 & 0.318943 & 0.047 \\
\hline $\mathrm{H} 7 \mathrm{c}$ & 0.782209 & 0.721233 & 0.364642 & 0.047 \\
\hline $\mathrm{H} 8 \mathrm{a}$ & 0.858009 & 0.395019 & 0.293519 & 0.062 \\
\hline H8b & 0.768316 & 0.319484 & 0.297486 & 0.062 \\
\hline H8c & 0.814389 & 0.363829 & 0.360347 & 0.062 \\
\hline $\mathrm{H} 9 \mathrm{a}$ & 0.402259 & 0.517321 & 0.283708 & 0.038 \\
\hline $\mathrm{H} 9 \mathrm{~b}$ & 0.448208 & 0.421773 & 0.254189 & 0.038 \\
\hline $\mathrm{H} 9 \mathrm{c}$ & 0.450172 & 0.519228 & 0.21494 & 0.038 \\
\hline $\mathrm{H} 10$ & 0.47714 & 0.85539 & 0.38123 & 0.02 \\
\hline $\mathrm{H} 14$ & 0.108658 & 0.734392 & 0.340338 & 0.028 \\
\hline $\mathrm{H} 15$ & 0.273811 & 0.691693 & 0.366505 & 0.026 \\
\hline $\mathrm{H} 17 \mathrm{a}$ & 0.573439 & 0.730063 & 0.504377 & 0.035 \\
\hline $\mathrm{H} 17 \mathrm{~b}$ & 0.583352 & 0.84766 & 0.507261 & 0.035 \\
\hline $\mathrm{H} 18 \mathrm{a}$ & 0.420661 & 0.660347 & 0.508938 & 0.03 \\
\hline $\mathrm{H} 18 \mathrm{~b}$ & 0.319042 & 0.726829 & 0.51537 & 0.03 \\
\hline $\mathrm{H} 19 \mathrm{a}$ & 0.442865 & 0.93921 & 0.516331 & 0.031 \\
\hline $\mathrm{H} 19 \mathrm{~b}$ & 0.331816 & 0.887621 & 0.519844 & 0.031 \\
\hline $\mathrm{H} 2 \mathrm{O}$ & 0.455451 & 0.792589 & 0.602404 & 0.032 \\
\hline $\mathrm{H} 1^{\prime}$ & $0.3953(16)$ & $0.3938(18)$ & $0.4975(10)$ & 0.022 \\
\hline H3' & 0.052989 & 0.363513 & 0.30444 & 0.031 \\
\hline H5' & 0.265624 & 0.159777 & 0.307635 & 0.028 \\
\hline $\mathrm{H} 7 \mathrm{I}^{\mathrm{a}}$ & 0.149292 & 0.529341 & 0.397185 & 0.047 \\
\hline $\mathrm{H} 7 \mathrm{\prime} \mathrm{b}$ & 0.07232 & 0.513153 & 0.340682 & 0.047 \\
\hline $\mathrm{H} 7{ }^{\prime} \mathrm{C}$ & 0.181716 & 0.554657 & 0.326877 & 0.047 \\
\hline H8'a & 0.081407 & 0.182516 & 0.228227 & 0.053 \\
\hline H8'b & 0.005774 & 0.198803 & 0.285424 & 0.053 \\
\hline $\mathrm{H} 8 \mathrm{C}$ & 0.088272 & 0.116103 & 0.28917 & 0.053 \\
\hline H9'a & 0.420813 & 0.238041 & 0.407215 & 0.034 \\
\hline H9'b & 0.46429 & 0.299943 & 0.350298 & 0.034 \\
\hline $\mathrm{H} 9 \mathrm{C}$ & 0.429762 & 0.191853 & 0.338791 & 0.034 \\
\hline H10' & 0.199772 & 0.434427 & 0.477779 & 0.02 \\
\hline H14' & 0.272141 & 0.06721 & 0.519023 & 0.029 \\
\hline H15' & 0.336452 & 0.223041 & 0.518494 & 0.026 \\
\hline $\mathrm{H} 17 \mathrm{c}$ & 0.340721 & 0.553678 & 0.583817 & 0.038 \\
\hline $\mathrm{H} 17 \mathrm{~d}$ & 0.219994 & 0.578617 & 0.580567 & 0.038 \\
\hline
\end{tabular}




\begin{tabular}{|lllll|}
$\mathrm{H} 18 \mathrm{c}$ & 0.311363 & 0.327593 & 0.638193 & 0.038 \\
$\mathrm{H} 18 \mathrm{~d}$ & 0.393022 & 0.409969 & 0.616712 & 0.038 \\
$\mathrm{H} 19 \mathrm{c}$ & 0.14431 & 0.360487 & 0.633801 & 0.051 \\
$\mathrm{H} 19 \mathrm{~d}$ & 0.106124 & 0.466404 & 0.609384 & 0.051 \\
$\mathrm{H} 20^{\prime}$ & 0.256543 & 0.496249 & 0.695755 & 0.042 \\
\hline
\end{tabular}


Table S5 . Refined Thermal Parameters (U's) for Compound 6246

\begin{tabular}{|c|c|c|c|c|c|c|}
\hline Atom & $U_{11}$ & $\mathrm{U}_{22}$ & $U_{33}$ & $U_{23}$ & $U_{13}$ & $U_{12}$ \\
\hline$\overline{\mathrm{Cl} 1}$ & $0.0280(2)$ & $0.01239(18)$ & $0.0365(2)$ & $0.00014(16)$ & $-0.00013(19)$ & $0.00000(16)$ \\
\hline $\mathrm{Cl} 2$ & $0.0220(2)$ & $0.0348(3)$ & $0.0377(3)$ & $-0.0025(2)$ & $-0.00389(19)$ & $0.00940(19)$ \\
\hline S1 & $0.0213(2)$ & $0.01479(18)$ & $0.01806(18)$ & $0.00158(14)$ & $0.00199(15)$ & $0.00251(16)$ \\
\hline 01 & $0.0280(7)$ & $0.0298(7)$ & $0.0219(6)$ & $0.0004(5)$ & $-0.0052(5)$ & $0.0082(6)$ \\
\hline N1 & $0.0212(7)$ & $0.0116(6)$ & $0.0198(7)$ & $0.0000(5)$ & $0.0045(5)$ & $0.0007(5)$ \\
\hline N2 & $0.0242(8)$ & $0.0195(7)$ & $0.0229(7)$ & $0.0007(6)$ & $0.0016(6)$ & $0.0050(6)$ \\
\hline C1 & $0.0212(8)$ & $0.0149(7)$ & $0.0156(7)$ & $0.0008(6)$ & $0.0016(6)$ & $0.0028(6)$ \\
\hline $\mathrm{C} 2$ & $0.0229(9)$ & $0.0252(9)$ & $0.0191(8)$ & $-0.0026(7)$ & $0.0007(7)$ & $0.0009(7)$ \\
\hline C3 & $0.0209(9)$ & $0.0364(11)$ & $0.0214(9)$ & $-0.0006(8)$ & $-0.0013(7)$ & $0.0070(8)$ \\
\hline C4 & $0.0332(10)$ & $0.028(1)$ & $0.0195(8)$ & $0.0034(7)$ & $0.0054(7)$ & $0.0128(8)$ \\
\hline C5 & $0.038(1)$ & $0.0164(8)$ & $0.0186(8)$ & $0.0003(6)$ & $0.0062(8)$ & $0.0048(8)$ \\
\hline C6 & $0.0249(8)$ & $0.0177(8)$ & $0.0143(7)$ & $-0.0001(6)$ & $0.0021(6)$ & $-0.0002(7)$ \\
\hline C7 & $0.0255(10)$ & $0.0333(11)$ & $0.0348(11)$ & $-0.0106(9)$ & $-0.0033(8)$ & $-0.0046(8)$ \\
\hline C8 & $0.0503(14)$ & $0.0419(13)$ & $0.0328(11)$ & $0.0072(10)$ & $0.0067(10)$ & $0.0278(12)$ \\
\hline C9 & $0.0305(10)$ & $0.0227(9)$ & $0.0224(9)$ & $-0.0018(7)$ & $-0.0014(7)$ & $-0.0057(8)$ \\
\hline C10 & $0.0190(8)$ & $0.0120(7)$ & $0.0196(8)$ & $-0.0004(6)$ & $0.0013(6)$ & $0.0006(6)$ \\
\hline C11 & $0.0196(8)$ & $0.0147(7)$ & $0.0170(7)$ & $0.0009(6)$ & $0.0025(6)$ & $0.0020(6)$ \\
\hline C12 & $0.0231(9)$ & $0.0154(8)$ & $0.0199(8)$ & $0.0001(6)$ & $0.0016(7)$ & $0.0004(7)$ \\
\hline C13 & $0.0195(8)$ & $0.0271(9)$ & $0.0209(8)$ & $-0.0004(7)$ & $0.0010(7)$ & $0.0071(7)$ \\
\hline C14 & $0.0209(8)$ & $0.0219(9)$ & $0.0275(9)$ & $-0.0008(7)$ & $-0.0001(7)$ & $-0.0006(7)$ \\
\hline C15 & $0.0217(9)$ & $0.0173(8)$ & $0.0254(9)$ & $0.0004(7)$ & $0.0011(7)$ & $0.0011(7)$ \\
\hline C16 & $0.0198(8)$ & $0.0157(8)$ & $0.0199(8)$ & $-0.0010(6)$ & $0.0014(6)$ & $0.0013(6)$ \\
\hline C17 & $0.0231(9)$ & $0.0399(11)$ & $0.0250(9)$ & $-0.0022(9)$ & $-0.0009(7)$ & $0.0017(8)$ \\
\hline C18 & $0.031(1)$ & $0.0212(9)$ & $0.0229(9)$ & $0.0025(7)$ & $0.0022(7)$ & $0.0003(7)$ \\
\hline C19 & $0.0336(10)$ & $0.0215(9)$ & $0.0221(9)$ & $-0.0049(7)$ & $0.0008(7)$ & $0.0026(7)$ \\
\hline C20 & $0.0261(9)$ & $0.0335(10)$ & $0.0199(8)$ & $-0.0009(8)$ & $-0.0012(7)$ & $0.0044(8)$ \\
\hline Cl1' & $0.01287(18)$ & $0.0232(2)$ & $0.0514(3)$ & $0.0061(2)$ & $-0.00093(19)$ & $0.00140(16)$ \\
\hline $\mathrm{Cl} 2^{\prime}$ & $0.0274(2)$ & $0.0177(2)$ & $0.0542(3)$ & $-0.0082(2)$ & $0.0096(2)$ & $-0.00445(17)$ \\
\hline$S 1^{\prime}$ & $0.01767(19)$ & $0.01477(18)$ & $0.01989(19)$ & $0.00117(15)$ & $0.00248(15)$ & $-0.00267(15)$ \\
\hline O1' & $0.0281(7)$ & $0.0137(6)$ & $0.0283(7)$ & $0.0013(5)$ & $0.0011(5)$ & $-0.0023(5)$ \\
\hline $\mathrm{N} 1^{\prime}$ & $0.0124(6)$ & $0.0245(7)$ & $0.0183(7)$ & $0.0039(6)$ & $0.0008(5)$ & $-0.0020(6)$ \\
\hline N2' & $0.0167(7)$ & $0.0215(8)$ & $0.0310(8)$ & $-0.0028(6)$ & $0.0023(6)$ & $-0.0026(6)$ \\
\hline C1' & $0.0206(8)$ & $0.0161(8)$ & $0.0186(8)$ & $0.0010(6)$ & $-0.0007(6)$ & $-0.0021(6)$ \\
\hline C2' & $0.0265(9)$ & $0.0174(8)$ & $0.0229(8)$ & $0.0006(7)$ & $-0.0027(7)$ & $0.0019(7)$ \\
\hline C3' & $0.0245(9)$ & $0.0260(9)$ & $0.0277(9)$ & $0.0008(7)$ & $-0.0064(8)$ & $0.0000(8)$ \\
\hline C4' & $0.0312(10)$ & $0.0230(9)$ & $0.0225(8)$ & $-0.0006(7)$ & $-0.0042(7)$ & $-0.0042(8)$ \\
\hline C5' & $0.0306(9)$ & $0.0168(8)$ & $0.0223(8)$ & $-0.0017(7)$ & $-0.0011(7)$ & $-0.0017(7)$ \\
\hline C6' & $0.0233(8)$ & $0.0163(8)$ & $0.0181(7)$ & $0.0030(6)$ & $0.0026(7)$ & $0.0004(7)$ \\
\hline C7' & $0.0306(10)$ & $0.0208(9)$ & $0.0425(12)$ & $-0.0014(8)$ & $-0.0087(9)$ & $0.0067(8)$ \\
\hline
\end{tabular}




\begin{tabular}{|lllllll} 
C8' & $0.0367(12)$ & $0.0285(11)$ & $0.0413(12)$ & $-0.0058(9)$ & $-0.0096(10)$ & $-0.0083(9)$ \\
C9' & $0.0231(9)$ & $0.0172(8)$ & $0.0286(9)$ & $0.0011(7)$ & $0.0036(7)$ & $0.0019(7)$ \\
C10' & $0.0133(7)$ & $0.0168(8)$ & $0.0207(8)$ & $0.0016(6)$ & $0.0024(6)$ & $-0.0001(6)$ \\
C11' & $0.0142(7)$ & $0.0184(8)$ & $0.0199(7)$ & $-0.0002(6)$ & $0.0025(6)$ & $-0.0002(6)$ \\
$C 12^{\prime}$ & $0.0142(8)$ & $0.0196(8)$ & $0.0263(9)$ & $0.0003(7)$ & $0.0012(6)$ & $0.0013(6)$ \\
$C 13^{\prime}$ & $0.0213(8)$ & $0.0188(8)$ & $0.0306(9)$ & $-0.0046(7)$ & $0.0061(8)$ & $-0.0037(7)$ \\
C14' & $0.0198(8)$ & $0.0194(9)$ & $0.034(1)$ & $-0.0012(7)$ & $0.0033(7)$ & $0.0033(7)$ \\
C15' & $0.0137(7)$ & $0.0216(9)$ & $0.0298(9)$ & $0.0019(7)$ & $0.0014(7)$ & $0.0001(6)$ \\
C16' & $0.0184(8)$ & $0.0221(9)$ & $0.0217(8)$ & $0.0001(7)$ & $0.0025(7)$ & $-0.0038(7)$ \\
C17' & $0.0406(12)$ & $0.0235(10)$ & $0.0318(10)$ & $-0.0062(8)$ & $-0.0032(9)$ & $-0.0002(9)$ \\
C18' & $0.0416(12)$ & $0.0279(10)$ & $0.026(1)$ & $0.0040(8)$ & $-0.0074(9)$ & $-0.0025(9)$ \\
$C 19^{\prime}$ & $0.0308(11)$ & $0.0665(17)$ & $0.0293(10)$ & $-0.0160(11)$ & $0.0114(9)$ & $-0.0162(11)$ \\
$C 20^{\prime}$ & $0.0377(11)$ & $0.0428(13)$ & $0.0235(9)$ & $-0.0085(9)$ & $0.0037(9)$ & $-0.0113(10)$
\end{tabular} \mid


Table S6. Bond Distances in Compound 6246, $\AA$

\begin{tabular}{|c|c|c|c|c|c|}
\hline Cl1-C12 & $1.7370(19)$ & $\mathrm{Cl} 2-\mathrm{C} 13$ & $1.7412(19)$ & S1-01 & $1.4857(15)$ \\
\hline $\mathrm{S} 1-\mathrm{N} 1$ & $1.6697(15)$ & S1-C1 & $1.8020(18)$ & $\mathrm{N} 1-\mathrm{C} 10$ & $1.468(2)$ \\
\hline N2-C12 & $1.329(2)$ & $\mathrm{N} 2-\mathrm{C} 13$ & $1.318(3)$ & C1-C2 & $1.410(3)$ \\
\hline C1-C6 & $1.400(2)$ & C2-C3 & $1.389(3)$ & C2-C7 & $1.514(3)$ \\
\hline 3-C4 & 1.389 & C4-C5 & 1.39 & C4-C8 & 1.507 \\
\hline 5-C6 & 1.40 & 26-C & 1.51 & $\mathrm{C} 1 \mathrm{C}$ & $1.523(2)$ \\
\hline C10-C16 & 1.516 & $\mathrm{C} 11-\mathrm{C} 12$ & 1.35 & C11. & $1.392(3)$ \\
\hline C13-C14 & $1.389(3)$ & C14-C15 & 1.38 & C16-C17 & $1.559(3)$ \\
\hline C16-C18 & 1.551 & C16-C19 & 1.55 & C17-C20 & $1.555(3)$ \\
\hline C18-C20 & $1.554(3)$ & C19-C20 & 1.55 & Cl1'-C12' & $1.7432(1$ \\
\hline Cl2'-C13' & $1.7406(19)$ & S1'-O1' & $1.4920(14)$ & S1'-N1' & $1.6474(15)$ \\
\hline S1'-C1' & $1.8036(18)$ & $\mathrm{N1} 1^{\prime}-\mathrm{C} 10^{\prime}$ & 1.465 & N2'-C12' & $1.332(2)$ \\
\hline N2'-C13' & 1.327 & C1'-C2' & 1.406 & $C 1^{\prime}-C 6^{\prime}$ & $1.412(2)$ \\
\hline C2'-C3' & $1.398(3)$ & C2'-C7' & $1.514(3)$ & C3'-C4' & $1.390(3)$ \\
\hline C4'-C5' & 1.389 & C4'-C8' & $1.510(3)$ & C5'-C6' & $1.393(3)$ \\
\hline C6'-C9' & $1.514(3)$ & C10'-C11 & $1.521(2)$ & $\mathrm{C} 1 \mathrm{C}$ & 1.5 \\
\hline C11'- & ' 1.395 & C11 & $1.3 s$ & $C 13^{\prime}-\mathrm{C} 1$ & $1.382(3)$ \\
\hline C14'-C15' & 1.38 & C16'-C & 1.55 & $C 16^{\prime}-\mathrm{C} 1$ & 1.5 \\
\hline C16'-C19' & 1.54 & C17'-C20 & .551 & C18'-C2 & $.553(3)$ \\
\hline & & & & & \\
\hline
\end{tabular}


Table S7. Bond Angles in Compound 6246, ${ }^{\circ}$

\begin{tabular}{|c|c|c|c|c|c|}
\hline O1-S1-N1 & $112.75(8)$ & O1-S1-C1 & $109.66(8)$ & N1-S1-C1 & $95.63(8)$ \\
\hline C10-N1-S1 & $115.43(11)$ & C13-N2-C12 & $116.26(16)$ & C2-C1-S1 & $114.51(13)$ \\
\hline C6-C1-S1 & $124.09(14)$ & $\mathrm{C} 6-\mathrm{C} 1-\mathrm{C} 2$ & $121.31(16)$ & $\mathrm{C} 1-\mathrm{C} 2-\mathrm{C} 7$ & $121.94(17)$ \\
\hline C3-C2-C1 & $118.44(18)$ & $\mathrm{C} 3-\mathrm{C} 2-\mathrm{C} 7$ & $119.62(18)$ & $\mathrm{C} 4-\mathrm{C} 3-\mathrm{C} 2$ & $122.00(19)$ \\
\hline C3-C4-C5 & $118.33(18)$ & C3-C4-C8 & $121.2(2)$ & C5-C4-C8 & $120.5(2)$ \\
\hline C4-C5-C6 & $122.22(18)$ & C1-C6-C5 & $117.70(17)$ & C1-C6-C9 & $124.44(17)$ \\
\hline C5-C6-C9 & $117.85(17)$ & N1-C10-C11 & $114.85(14)$ & N1-C10-C16 & $107.23(14)$ \\
\hline C16-C10-C11 & $110.29(14)$ & $\mathrm{C} 12-\mathrm{C} 11-\mathrm{C} 10$ & $122.18(16)$ & C15-C11-C10 & $122.02(15)$ \\
\hline C15-C11-C12 & $115.78(17)$ & $\mathrm{N} 2-\mathrm{C} 12-\mathrm{Cl} 1$ & $114.90(14)$ & N2-C12-C11 & $125.60(17)$ \\
\hline C11-C12-Cl1 & $119.50(14)$ & $\mathrm{N} 2-\mathrm{C} 13-\mathrm{Cl} 2$ & $116.43(14)$ & N2-C13-C14 & $124.82(18)$ \\
\hline C14-C13-Cl2 & $118.75(15)$ & C15-C14-C13 & $117.19(18)$ & C14-C15-C11 & $120.34(17)$ \\
\hline C10-C16-C17 & $127.03(15)$ & $\mathrm{C} 10-\mathrm{C} 16-\mathrm{C} 18$ & $125.95(15)$ & C10-C16-C19 & $128.41(16)$ \\
\hline C18-C16-C17 & $87.34(14)$ & C18-C16-C19 & $87.15(14)$ & C19-C16-C17 & $87.48(14)$ \\
\hline C20-C17-C16 & $74.00(13)$ & C16-C18-C20 & $74.27(13)$ & C20-C19-C16 & $74.13(13)$ \\
\hline C18-C20-C17 & $87.38(15)$ & C19-C20-C17 & $87.87(15)$ & C19-C20-C18 & $87.32(14)$ \\
\hline O1'-S1'-N1' & $111.00(8)$ & O1'-S1'-C1' & $107.81(8)$ & N1'-S1'-C1' & $96.16(8)$ \\
\hline C10'-N1'-S1' & $123.06(12)$ & C13'-N2'-C12' & $116.27(16)$ & C2'-C1'-S1' & $125.01(14)$ \\
\hline $\mathrm{C} 2{ }^{\prime}-\mathrm{C} 1^{\prime}-\mathrm{C} 6{ }^{\prime}$ & $121.34(17)$ & C6'-C1'-S1' & $113.63(14)$ & $C 1^{\prime}-C 2 '-C 7^{\prime}$ & $125.45(17)$ \\
\hline C3'-C2'-C1' & $117.15(17)$ & C3'-C2'-C7' & $117.38(18)$ & C4'-C3'-C2' & $122.84(19)$ \\
\hline C3'-C4'-C8' & $120.54(19)$ & C5'-C4'-C3' & $118.36(18)$ & C5'-C4'-C8' & $121.10(19)$ \\
\hline C4'-C5'-C6' & $121.64(18)$ & C1'-C6'-C9' & $122.20(17)$ & C5'-C6'-C1' & $118.47(17)$ \\
\hline C5'-C6'-C9' & 119.33(17) & N1'-C10'-C11' & $110.65(14)$ & $N 1^{\prime}-\mathrm{C} 10^{\prime}-\mathrm{C} 16^{\prime}$ & $109.85(14)$ \\
\hline C16'-C10'-C11' & ' 110.23(14) & C12'-C11'-C10' & ' 123.95(16) & C15'-C11'-C10' & $120.47(15)$ \\
\hline C15'-C11'-C12' & ' 115.51(16) & N2'-C12'-Cl1' & $115.29(13)$ & N2'-C12'-C11' & $125.44(17)$ \\
\hline C11'-C12'-Cl1' & $119.27(14)$ & N2'-C13'-Cl2' & $116.16(14)$ & N2'-C13'-C14' & $124.62(17)$ \\
\hline C14'-C13'-Cl2' & $119.21(15)$ & C15'-C14'-C13' & '117.30(17) & C14'-C15'-C11' & $120.84(16)$ \\
\hline C10'-C16'-C17' & ' 125.91(16) & C10'-C16'-C18' & 127.96(17) & C10'-C16'-C19' & $127.28(17)$ \\
\hline C18'-C16'-C17' & ' 86.89(15) & C19'-C16'-C17' & ' 87.57(17) & C19'-C16'-C1 & $87.84(17)$ \\
\hline C20'-C17'-C16' & ' 74.04(15) & C20'-C18'-C16' & 74.01(15) & C16'-C19'-C2C & $74.26(15)$ \\
\hline C17'-C20'-C18' & ' 87.09(16) & C17'-C20'-C19' & 87.58(18) & C19'-C20'-C18' & $87.70(18)$ \\
\hline
\end{tabular}

This report has been created with Olex2 [8], compiled on 2020.11 .12 svn.r5f609507 for OlexSys. 


\section{X-ray Structure Determination of Compound 6247}

Procedure for crystallization: The $\mathrm{BCP}$ sulfinamide is dissolved in a generous quantity of $\mathrm{Et}_{2} \mathrm{O}$ in a $4 \mathrm{~mL}$ vial. The vial is then placed, uncapped, into a $20 \mathrm{~mL}$ vial which contains a generous quantity of $n$-pentane. The $20 \mathrm{~mL}$ vial is capped and left at room temperature. After 1 hour, slow evaporation of the $\mathrm{Et}_{2} \mathrm{O}$ layer into the $n$-pentane layer produces, white, hexagonal, clear crystals.
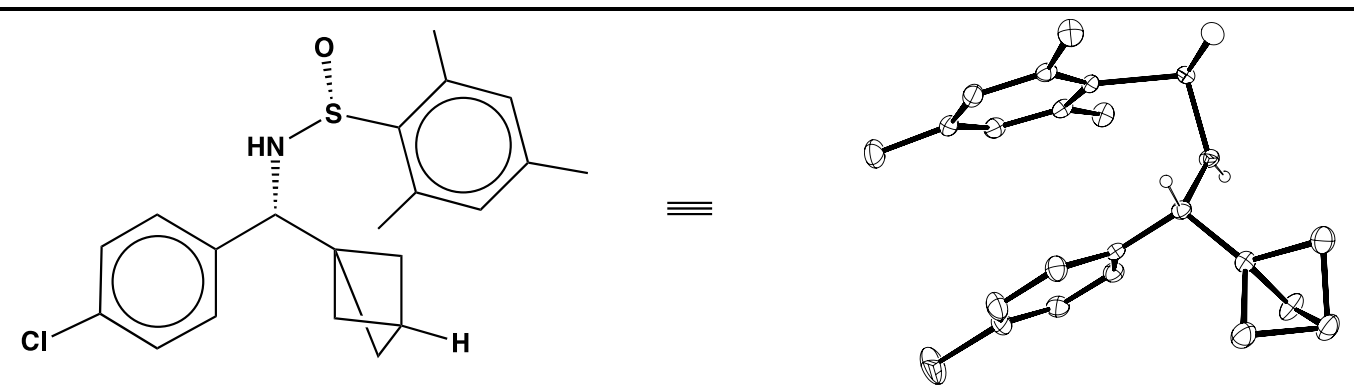

Compound 6247, $\mathrm{C}_{21} \mathrm{H}_{24} \mathrm{ClNOS}$, crystallizes in the orthorhombic space group $\mathrm{P} 2{ }_{1} 2_{1} 2_{1}$ (systematic absences h00: $\mathrm{h}=\mathrm{odd}, 0 \mathrm{k} 0: \mathrm{k}=\mathrm{odd}$, and 001: $\mathrm{l}=$ odd) with $\mathrm{a}=8.6173(2) \AA$, $\mathrm{b}=9.8776(2) \AA, c=22.8394(5) \AA, V=1944.05(7) \AA^{3}, \mathrm{Z}=4$, and $\mathrm{d}_{\mathrm{calc}}=1.278 \mathrm{~g} / \mathrm{cm}^{3} . \mathrm{X}$-ray intensity data were collected on a Rigaku XtaLAB Synergy-S diffractometer [1] equipped with an HPC area detector (Dectris Pilatus3 R 200K) and employing confocal multilayer optic-monochromated MoK $\alpha$ radiation $(\lambda=0.71073 \AA)$ at a temperature of $100 \mathrm{~K}$. Preliminary indexing was performed from a series of thirty $0.5^{\circ}$ rotation frames with exposures of $1.25 \mathrm{sec}$. A total of 2268 frames (18 runs) were collected employing $\omega$ scans with a crystal to detector distance of $34.0 \mathrm{~mm}$, rotation widths of $0.5^{\circ}$ and exposures of $10 \mathrm{sec}$.

Rotation frames were integrated using CrysAlisPro [2], producing a listing of unaveraged $\mathrm{F}^{2}$ and $\sigma\left(\mathrm{F}^{2}\right)$ values. A total of 76175 reflections were measured over the ranges $5.052 \leq 2 \theta \leq$ $56.558^{\circ},-11 \leq \mathrm{h} \leq 11,-13 \leq \mathrm{k} \leq 13,-30 \leq 1 \leq 30$ yielding 4823 unique reflections $\left(\mathrm{R}_{\text {int }}=0.0513\right)$. The intensity data were corrected for Lorentz and polarization effects and for absorption using SCALE3 ABSPACK [3] (minimum and maximum transmission 0.7375, 1.0000). The structure was solved by direct methods - ShelXT [4]. Refinement was by full-matrix least squares based on $\mathrm{F}^{2}$ using SHELXL-2018 [5]. All reflections were used during refinement. The weighting scheme 
used was $\mathrm{w}=1 /\left[\sigma^{2}\left(\mathrm{~F}_{\mathrm{o}}^{2}\right)+(0.0373 \mathrm{P})^{2}+0.3426 \mathrm{P}\right]$ where $\mathrm{P}=\left(\mathrm{F}_{\mathrm{o}}^{2}+2 \mathrm{~F}_{\mathrm{c}}^{2}\right) / 3$. Non-hydrogen atoms were refined anisotropically and hydrogen atoms were refined using a riding model. Refinement converged to $\mathrm{R} 1=0.0236$ and $\mathrm{wR} 2=0.0622$ for 4657 observed reflections for which $\mathrm{F}>4 \sigma(\mathrm{F})$ and $\mathrm{R} 1=0.0249$ and $\mathrm{wR} 2=0.0628$ and $\mathrm{GOF}=1.038$ for all 4823 unique, non-zero reflections and 229 variables. The maximum $\Delta / \sigma$ in the final cycle of least squares was 0.000 and the two most prominent peaks in the final difference Fourier were +0.26 and $-0.20 \mathrm{e} / \AA^{3}$. The Hooft absolute structure parameter y [6] was calculated using PLATON [7] The resulting value was y $=0.001(6)$ indicating that the absolute structure has been assigned correctly. The Flack parameter [8] refined to a similar value of $0.004(14)$. If these parameters are equal to 0 (within 3 standard deviations) then the absolute structure has been assigned correctly; if they are 1, the opposite enantiomer has been modeled.

Table 1. lists cell information, data collection parameters, and refinement data. Final positional and equivalent isotropic thermal parameters are given in Tables 2. and 3. Anisotropic thermal parameters are in Table 4. Tables 5. and 6. list bond distances and bond angles. Figure 1. is an ORTEP representation of the molecule with 50\% probability thermal ellipsoids displayed. 


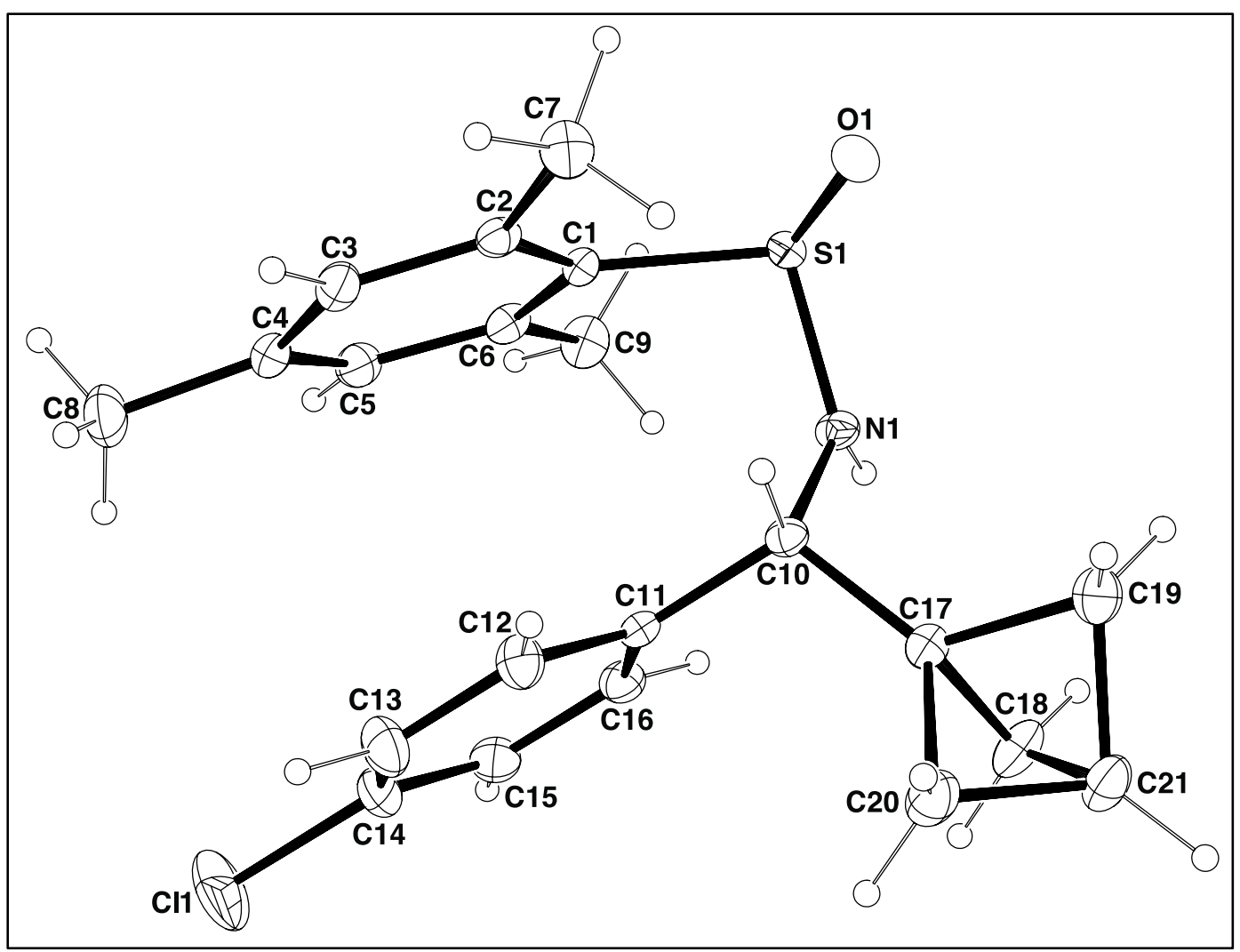

Figure S15. ORTEP drawing of the title compound with $50 \%$ thermal ellipsoids. 
Table 1. Summary of Structure Determination of Compound 6247

\begin{tabular}{|c|c|}
\hline Empirical formula & $\mathrm{C}_{21} \mathrm{H}_{24} \mathrm{CINOS}$ \\
\hline Formula weight & 373.92 \\
\hline Diffractometer & Rigaku XtaLAB Synergy-S \\
\hline Temperature/K & 100 \\
\hline Crystal system & orthorhombic \\
\hline Space group & $\mathrm{P} 2{ }_{1} 2_{1} 2_{1}$ \\
\hline a & $8.6173(2) \AA$ \\
\hline b & $9.8776(2) \AA$ \\
\hline c & $22.8394(5) \AA$ \\
\hline Volume & $1944.05(7) \AA^{3}$ \\
\hline Z & 4 \\
\hline $\mathrm{d}_{\text {calc }}$ & $1.278 \mathrm{~g} / \mathrm{cm}^{3}$ \\
\hline$\mu$ & $0.312 \mathrm{~mm}^{-1}$ \\
\hline$F(000)$ & 792.0 \\
\hline Crystal size, $\mathrm{mm}$ & $0.19 \times 0.13 \times 0.1$ \\
\hline $2 \theta$ range for data collection & $5.052-56.558^{\circ}$ \\
\hline Index ranges & $-11 \leq h \leq 11,-13 \leq k \leq 13,-30 \leq \mathrm{I} \leq 30$ \\
\hline Reflections collected & 76175 \\
\hline Independent reflections & $4823[R($ int $)=0.0513]$ \\
\hline Data/restraints/parameters & $4823 / 0 / 229$ \\
\hline Goodness-of-fit on $F^{2}$ & 1.038 \\
\hline Final $R$ indexes $[I>=2 \sigma(I)]$ & $\mathrm{R}_{1}=0.0236, w \mathrm{R}_{2}=0.0622$ \\
\hline Final $R$ indexes [all data] & $R_{1}=0.0249, w R_{2}=0.0628$ \\
\hline
\end{tabular}


Largest diff. peak/hole

$0.26 /-0.20 \mathrm{e}^{-3}$

Flack parameter

$0.004(14)$

Table S8. Refined Positional Parameters for Compound 6247

\begin{tabular}{|c|c|c|c|c|}
\hline Atom & $\bar{x}$ & $y$ & $z$ & $U(e q)$ \\
\hline $\mathrm{Cl} 1$ & $-0.00242(7)$ & $0.68440(5)$ & $0.49772(2)$ & $0.04069(14)$ \\
\hline S1 & $0.54301(4)$ & $0.33539(4)$ & $0.28867(2)$ & $0.01375(8)$ \\
\hline 01 & $0.52554(15)$ & $0.19979(11)$ & $0.26070(5)$ & $0.0221(2)$ \\
\hline N1 & $0.39834(15)$ & $0.42987(13)$ & $0.26632(6)$ & $0.0140(2)$ \\
\hline C1 & $0.49190(16)$ & $0.31609(15)$ & $0.36506(6)$ & $0.0130(3)$ \\
\hline C2 & $0.41260(17)$ & $0.20435(16)$ & $0.38850(6)$ & $0.0142(3)$ \\
\hline C3 & $0.35491(18)$ & $0.21641(17)$ & $0.44549(7)$ & $0.0169(3)$ \\
\hline C4 & $0.37680(18)$ & $0.33240(17)$ & $0.47920(6)$ & $0.0178(3)$ \\
\hline C5 & $0.46798(19)$ & $0.43581(15)$ & $0.45634(6)$ & $0.0178(3)$ \\
\hline C6 & $0.52641(18)$ & $0.43055(15)$ & $0.39951(6)$ & $0.0156(3)$ \\
\hline C7 & $0.3860(2)$ & $0.07055(16)$ & $0.35739(7)$ & $0.0193(3)$ \\
\hline C8 & $0.3032(2)$ & $0.3456(2)$ & $0.53887(7)$ & $0.0252(4)$ \\
\hline C9 & $0.6205(2)$ & $0.54883(17)$ & $0.37683(7)$ & $0.0208(3)$ \\
\hline C10 & $0.23537(16)$ & $0.40234(15)$ & $0.28058(6)$ & $0.0128(3)$ \\
\hline C11 & $0.17719(17)$ & $0.47570(15)$ & $0.33505(6)$ & $0.0136(3)$ \\
\hline C12 & $0.07687(19)$ & $0.40907(17)$ & $0.37309(7)$ & $0.0186(3)$ \\
\hline C13 & $0.0207(2)$ & $0.47302(17)$ & $0.42318(7)$ & $0.0231(3)$ \\
\hline C14 & $0.0670(2)$ & $0.60449(18)$ & $0.43469(7)$ & $0.0216(3)$ \\
\hline C15 & $0.16600(19)$ & $0.67316(17)$ & $0.39761(7)$ & $0.0201(3)$ \\
\hline
\end{tabular}




$\left|\begin{array}{lllll}\text { C16 } & 0.22047(18) & 0.60861(16) & 0.34744(7) & 0.0171(3) \\ \text { C17 } & 0.13855(17) & 0.43613(16) & 0.22701(6) & 0.0146(3) \\ \text { C18 } & 0.1315(2) & 0.57247(17) & 0.19309(7) & 0.0221(3) \\ \text { C19 } & 0.1472(2) & 0.36490(19) & 0.16654(7) & 0.0237(4) \\ \text { C20 } & -0.04088(19) & 0.43028(19) & 0.22149(7) & 0.0235(3) \\ \text { C21 } & 0.01983(19) & 0.47482(17) & 0.16049(7) & 0.0206(3)\end{array}\right|$

Table S9. Positional Parameters for Hydrogens in Compound 6247

\begin{tabular}{|c|c|c|c|c|}
\hline Atom & $x$ & $y$ & $z$ & $U(e q)$ \\
\hline $\mathrm{H} 1$ & 0.4243 & 0.5171 & 0.2575 & 0.019 \\
\hline H3 & 0.298699 & 0.142788 & 0.461817 & 0.02 \\
\hline H5 & 0.491067 & 0.512118 & 0.480121 & 0.021 \\
\hline $\mathrm{H} 7 \mathrm{a}$ & 0.322977 & 0.085759 & 0.322281 & 0.029 \\
\hline $\mathrm{H} 7 \mathrm{~b}$ & 0.331649 & 0.008106 & 0.38369 & 0.029 \\
\hline H7c & 0.486119 & 0.031411 & 0.346122 & 0.029 \\
\hline $\mathrm{H} 8 \mathrm{a}$ & 0.380928 & 0.326686 & 0.569124 & 0.038 \\
\hline $\mathrm{H} 8 \mathrm{~b}$ & 0.217547 & 0.280865 & 0.542346 & 0.038 \\
\hline $\mathrm{H} 8 \mathrm{c}$ & 0.263461 & 0.43781 & 0.543911 & 0.038 \\
\hline H9a & 0.715219 & 0.515086 & 0.358058 & 0.031 \\
\hline $\mathrm{H} 9 \mathrm{~b}$ & 0.648388 & 0.608326 & 0.409515 & 0.031 \\
\hline H9c & 0.558969 & 0.599644 & 0.348218 & 0.031 \\
\hline $\mathrm{H} 10$ & 0.225279 & 0.302904 & 0.287868 & 0.015 \\
\hline $\mathrm{H} 12$ & 0.046216 & 0.318694 & 0.364809 & 0.022 \\
\hline $\mathrm{H} 13$ & -0.048053 & 0.427196 & 0.44895 & 0.028 \\
\hline
\end{tabular}




\begin{tabular}{|lllll}
$\mathrm{H} 15$ & 0.196632 & 0.763388 & 0.40621 & 0.024 \\
$\mathrm{H} 16$ & 0.287667 & 0.655545 & 0.321458 & 0.02 \\
$\mathrm{H} 18 \mathrm{a}$ & 0.082188 & 0.64914 & 0.213922 & 0.026 \\
$\mathrm{H} 18 \mathrm{~b}$ & 0.226744 & 0.598724 & 0.171709 & 0.026 \\
$\mathrm{H} 19 \mathrm{a}$ & 0.243401 & 0.380082 & 0.143742 & 0.028 \\
$\mathrm{H} 19 \mathrm{~b}$ & 0.111173 & 0.269779 & 0.165338 & 0.028 \\
$\mathrm{H} 20 \mathrm{a}$ & -0.08816 & 0.33906 & 0.223576 & 0.028 \\
$\mathrm{H} 20 \mathrm{~b}$ & -0.099408 & 0.499286 & 0.243865 & 0.028 \\
$\mathrm{H} 21$ & -0.043661 & 0.495399 & 0.124939 & 0.025 \\
\hline
\end{tabular}

Table S10. Refined Thermal Parameters (U's) for Compound 6247

\begin{tabular}{|lcccccc|}
\hline Atom & $\mathbf{U}_{11}$ & $\mathbf{U}_{22}$ & $\mathbf{U}_{33}$ & $U_{23}$ & $U_{13}$ & $U_{12}$ \\
\hline Cl1 & $0.0619(3)$ & $0.0311(2)$ & $0.0291(2)$ & $-0.01022(18)$ & $0.0212(2)$ & $0.0022(2)$ \\
S1 & $0.01325(15)$ & $0.01523(17)$ & $0.01275(15)$ & $0.00022(13)$ & $0.00167(12)$ & $0.00292(13)$ \\
O1 & $0.0331(6)$ & $0.0159(5)$ & $0.0171(5)$ & $-0.0033(4)$ & $0.0012(5)$ & $0.0086(5)$ \\
N1 & $0.0138(5)$ & $0.0122(6)$ & $0.0161(6)$ & $0.0039(5)$ & $0.0013(5)$ & $0.0009(5)$ \\
C1 & $0.0135(6)$ & $0.0148(7)$ & $0.0108(6)$ & $0.0005(5)$ & $-0.0015(5)$ & $0.0024(5)$ \\
C2 & $0.0130(6)$ & $0.0146(7)$ & $0.0150(7)$ & $0.0004(5)$ & $-0.0028(5)$ & $0.0018(5)$ \\
C3 & $0.0172(7)$ & $0.0185(7)$ & $0.0151(7)$ & $0.0031(6)$ & $-0.0008(6)$ & $-0.0006(6)$ \\
C4 & $0.0196(7)$ & $0.0217(7)$ & $0.0122(6)$ & $0.0010(6)$ & $-0.0019(5)$ & $0.0048(6)$ \\
C5 & $0.0216(7)$ & $0.0158(7)$ & $0.0158(7)$ & $-0.0033(5)$ & $-0.0044(6)$ & $0.0023(6)$ \\
C6 & $0.0166(7)$ & $0.0135(6)$ & $0.0167(6)$ & $0.0014(5)$ & $-0.0037(6)$ & $0.0009(6)$ \\
C7 & $0.0224(8)$ & $0.0157(7)$ & $0.0199(7)$ & $-0.0012(6)$ & $0.0003(6)$ & $-0.0036(6)$ \\
C8 & $0.0324(9)$ & $0.0290(9)$ & $0.0143(7)$ & $-0.0013(6)$ & $0.0031(6)$ & $0.0006(8)$ \\
& & & & & &
\end{tabular}




$\left|\begin{array}{lllllll}C 9 & 0.0237(8) & 0.0173(8) & 0.0215(8) & 0.0004(6) & -0.0018(6) & -0.0049(6) \\ C 10 & 0.0132(6) & 0.0110(6) & 0.0141(6) & 0.0018(5) & -0.0002(5) & 0.0004(5) \\ C 11 & 0.0130(7) & 0.0152(7) & 0.0125(6) & 0.0023(5) & -0.0021(5) & 0.0034(5) \\ C 12 & 0.0210(8) & 0.0174(7) & 0.0175(7) & 0.0006(6) & 0.0016(6) & -0.0023(6) \\ C 13 & 0.0271(9) & 0.0223(8) & 0.0199(7) & 0.0017(6) & 0.0086(7) & -0.0015(7) \\ C 14 & 0.0271(9) & 0.0217(8) & 0.0160(7) & -0.0026(6) & 0.0040(6) & 0.0062(7) \\ C 15 & 0.0245(8) & 0.0138(7) & 0.0220(7) & -0.0005(6) & 0.0003(6) & 0.0038(6) \\ C 16 & 0.0181(7) & 0.0145(7) & 0.0186(7) & 0.0037(6) & 0.0008(6) & 0.0019(6) \\ C 17 & 0.0154(7) & 0.0147(7) & 0.0137(7) & 0.0006(5) & -0.0013(5) & 0.0000(5) \\ C 18 & 0.0268(8) & 0.0202(8) & 0.0192(7) & 0.0062(6) & -0.0083(6) & -0.0020(7) \\ C 19 & 0.0256(8) & 0.0281(9) & 0.0173(8) & -0.0061(6) & -0.0051(6) & 0.0031(7) \\ C 20 & 0.0166(7) & 0.0335(9) & 0.0202(8) & 0.0060(6) & -0.0018(6) & -0.0005(7) \\ C 21 & 0.0185(8) & 0.0270(8) & 0.0164(7) & 0.0039(6) & -0.0047(6) & -0.0022(6)\end{array}\right|$

Table S11. Bond Distances in Compound 6247, ^̊

$\begin{array}{|llllll|}\mathrm{Cl1}-\mathrm{C} 14 & 1.7473(16) & \mathrm{S} 1-\mathrm{O} 1 & 1.4916(11) & \mathrm{S} 1-\mathrm{N} 1 & 1.6388(13) \\ \mathrm{S} 1-\mathrm{C} 1 & 1.8094(14) & \mathrm{N} 1-\mathrm{C} 10 & 1.4670(18) & \mathrm{C} 1-\mathrm{C} 2 & 1.404(2) \\ \mathrm{C} 1-\mathrm{C} 6 & 1.409(2) & \mathrm{C} 2-\mathrm{C} 3 & 1.398(2) & \mathrm{C} 2-\mathrm{C} 7 & 1.518(2) \\ \mathrm{C} 3-\mathrm{C} 4 & 1.393(2) & \mathrm{C} 4-\mathrm{C} 5 & 1.391(2) & \mathrm{C} 4-\mathrm{C} 8 & 1.509(2) \\ \mathrm{C} 5-\mathrm{C} 6 & 1.393(2) & \mathrm{C} 6-\mathrm{C} 9 & 1.514(2) & \mathrm{C} 10-\mathrm{C} 111.525(2) \\ \mathrm{C} 10-\mathrm{C} 17 & 1.518(2) & \mathrm{C} 11-\mathrm{C} 121.391(2) & \mathrm{C} 11-\mathrm{C} 161.394(2) \\ \mathrm{C} 12-\mathrm{C} 13 & 1.393(2) & \mathrm{C} 13-\mathrm{C} 141.384(2) & \mathrm{C} 14-\mathrm{C} 151.380(2) \\ \mathrm{C} 15-\mathrm{C} 16 & 1.393(2) & \mathrm{C} 17-\mathrm{C} 181.555(2) & \mathrm{C} 17-\mathrm{C} 19 & 1.552(2)\end{array}$




$\mid \begin{array}{ll}\mathrm{C} 17-\mathrm{C} 201.552(2) \quad \mathrm{C} 18-\mathrm{C} 211.552(2) \quad \mathrm{C} 19-\mathrm{C} 211.550(2) \\ \mathrm{C} 20-\mathrm{C} 211.552(2)\end{array}$

\section{Table S11. Bond Angles in Compound 6247,}

\begin{tabular}{|c|c|c|c|c|c|}
\hline O1-S1-N1 & $107.53(7)$ & O1-S1-C1 & $107.08(7)$ & N1-S1-C1 & $100.09(6)$ \\
\hline C10-N1-S1 & $123.61(10)$ & C2-C1-S1 & $124.68(11)$ & C2-C1-C6 & $121.36(13$ \\
\hline C6-C1-S1 & $113.73(11)$ & C1-C2-C7 & $125.41(13)$ & $\mathrm{C} 3-\mathrm{C} 2-\mathrm{C} 1$ & $117.45(14)$ \\
\hline C3-C2-C7 & $117.14(14)$ & C4-C3-C2 & $122.44(15)$ & С3-C4-C8 & $120.89(15)$ \\
\hline C5-C4-C3 & $118.23(14)$ & C5-C4-C8 & $120.87(15)$ & C4-C5-C6 & $121.78(14)$ \\
\hline C1-C6-C9 & $122.77(13)$ & C5-C6-C1 & $118.29(14)$ & C5-C6-C9 & $118.93(13)$ \\
\hline N1-C10-C11 & $114.07(12)$ & N1-C10-C17 & $107.85(12)$ & $\mathrm{C} 17-\mathrm{C} 10-\mathrm{C} 11$ & $111.87(12)$ \\
\hline C12-C11-C10 & $119.29(14)$ & $\mathrm{C} 12-\mathrm{C} 11-\mathrm{C} 16$ & 119.02(14) & C16-C11-C10 & 121.69(13) \\
\hline C11-C12-C13 & $120.93(15)$ & $\mathrm{C} 14-\mathrm{C} 13-\mathrm{C} 12$ & $118.77(15)$ & $\mathrm{C} 13-\mathrm{C} 14-\mathrm{Cl} 1$ & $118.80(13$ \\
\hline C15-C14-Cl1 & $119.68(13)$ & $\mathrm{C} 15-\mathrm{C} 14-\mathrm{C} 13$ & $121.52(15)$ & C14-C15-C16 & $119.21(15$ \\
\hline C15-C16-C11 & $120.54(15)$ & C10-C17-C18 & $127.85(13)$ & C10-C17-C19 & $126.23(13)$ \\
\hline C10-C17-C2O & $127.20(13)$ & C19-C17-C18 & $87.21(12)$ & C19-C17-C20 & $87.65(12)$ \\
\hline C20-C17-C18 & $87.29(12)$ & $\mathrm{C} 21-\mathrm{C} 18-\mathrm{C} 17$ & $74.05(11)$ & C21-C19-C17 & 74.19(11) \\
\hline C21-C2O-C17 & $74.13(11)$ & $\mathrm{C} 19-\mathrm{C} 21-\mathrm{C} 18$ & $87.34(12)$ & C19-C21-C20 & $87.72(12)$ \\
\hline C2O-C21-C18 & 87.39 & & & & \\
\hline
\end{tabular}

Table S12. Hydrogen Bonds for 6247

\begin{tabular}{llllllll}
\hline D & $H$ & $A$ & $d(D-H) / A ̊$ & $d(H-A) / A ̊$ & $d(D-A) / A ̊$ & $D-H-A /^{\circ}$
\end{tabular} 
N1 H1 O1 ${ }^{1} 0.9127(13) 1.9016(11) 2.8141(17) 178.94(9)$

$11-X, 1 / 2+Y, 1 / 2-Z$

This report has been created with Olex2 [6], compiled on 2018.05.29 svn.r3508 for OlexSys. 


\section{X-ray Structure Determination of Compound 6248}

Procedure for crystallization: See procedure for 6246 above.

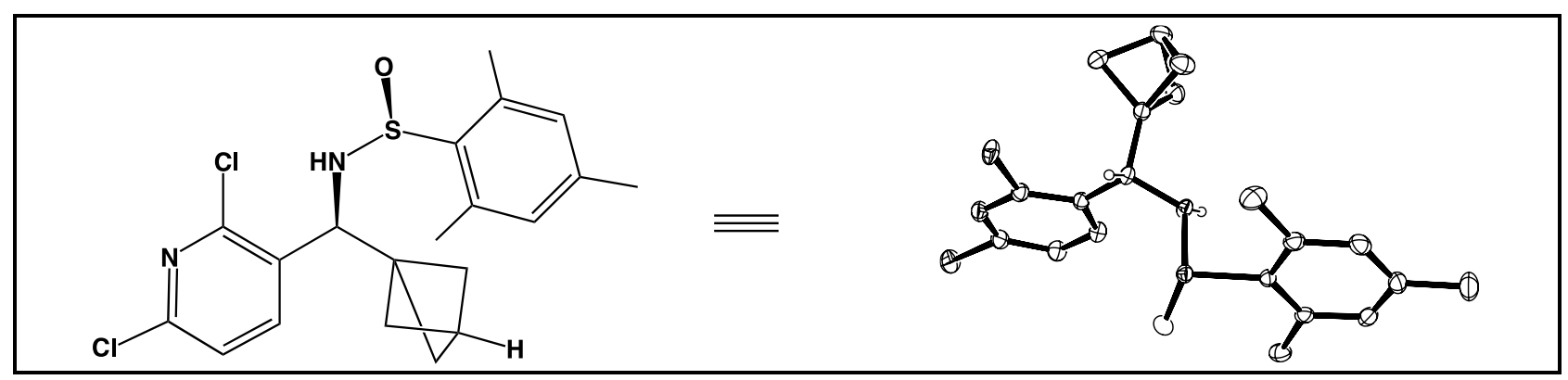

Compound $6248, \mathrm{C}_{20} \mathrm{H}_{22} \mathrm{Cl}_{2} \mathrm{~N}_{2} \mathrm{OS}$, crystallizes in the orthorhombic space group $\mathrm{P} 2{ }_{1} 2_{1} 2_{1}$ (systematic absences h00: h=odd, 0k0: k=odd, and 001: l=odd) with $\mathrm{a}=13.3677(3) \AA$, $\mathrm{b}=14.0012(3) \AA, \mathrm{c}=21.3224(5) \AA, \mathrm{V}=3990.78(16) \AA^{3}, \mathrm{Z}=8$, and $\mathrm{d}_{\text {calc }}=1.363 \mathrm{~g} / \mathrm{cm}^{3}$. X-ray intensity data were collected on a Rigaku XtaLAB Synergy-S diffractometer [1] equipped with an HPC area detector (Dectris Pilatus3 R 200K) and employing confocal multilayer optic-monochromated Mo$\mathrm{K} \alpha$ radiation $(\lambda=0.71073 \AA)$ at a temperature of $100 \mathrm{~K}$. Preliminary indexing was performed from a series of thirty $0.5^{\circ}$ rotation frames with exposures of $0.25 \mathrm{sec}$. A total of 1178 frames (10 runs) were collected employing $\omega$ scans with a crystal to detector distance of $34.0 \mathrm{~mm}$, rotation widths of $0.5^{\circ}$ and exposures of $5 \mathrm{sec}$.

Rotation frames were integrated using CrysAlisPro [2], producing a listing of unaveraged $\mathrm{F}^{2}$ and $\sigma\left(\mathrm{F}^{2}\right)$ values. A total of 81641 reflections were measured over the ranges $4.626 \leq 2 \theta \leq$ $56.56^{\circ},-17 \leq \mathrm{h} \leq 17,-18 \leq \mathrm{k} \leq 18,-28 \leq 1 \leq 28$ yielding 9897 unique reflections $\left(\mathrm{R}_{\mathrm{int}}=0.0466\right)$. The intensity data were corrected for Lorentz and polarization effects and for absorption using SCALE3 ABSPACK [3] (minimum and maximum transmission 0.7674, 1.0000). The structure was solved by direct methods - ShelXT (Sheldrick, 2015) [4]. Refinement was by full-matrix least squares based on $\mathrm{F}^{2}$ using SHELXL-2018 [5]. All reflections were used during refinement. The weighting scheme used was $\mathrm{w}=1 /\left[\sigma^{2}\left(\mathrm{~F}_{\mathrm{o}}^{2}\right)+(0.0338 \mathrm{P})^{2}+0.7110 \mathrm{P}\right]$ where $\mathrm{P}=\left(\mathrm{F}_{\mathrm{o}}^{2}+2 \mathrm{~F}_{\mathrm{c}}^{2}\right) / 3$. Non- 
hydrogen atoms were refined anisotropically and hydrogen atoms were refined using a riding model. Refinement converged to $\mathrm{R} 1=0.0250$ and $\mathrm{wR} 2=0.0610$ for 9437 observed reflections for which $\mathrm{F}>4 \sigma(\mathrm{F})$ and $\mathrm{R} 1=0.0270$ and $\mathrm{wR} 2=0.0616$ and $\mathrm{GOF}=1.034$ for all 9897 unique, non-zero reflections and 475 variables. The maximum $\Delta / \sigma$ in the final cycle of least squares was 0.001 and the two most prominent peaks in the final difference Fourier were +0.26 and $-0.21 \mathrm{e} / \AA^{3}$. The Hooft absolute structure parameter y [6] was calculated using PLATON [7] The resulting value was y = $-0.017(1)$ indicating that the absolute structure has been assigned correctly. The Flack parameter [8] refined to a similar value of $-0.014(12$ ). If these parameters are equal to 0 (within 3 standard deviations) then the absolute structure has been assigned correctly; if they are 1, the opposite enantiomer has been modeled.

Table 1. lists cell information, data collection parameters, and refinement data. Final positional and equivalent isotropic thermal parameters are given in Tables 2. and 3. Anisotropic thermal parameters are in Table 4. Tables 5. and 6. list bond distances and bond angles. Figures 1. and 2. are ORTEP representations of the molecule with $50 \%$ probability thermal ellipsoids displayed.

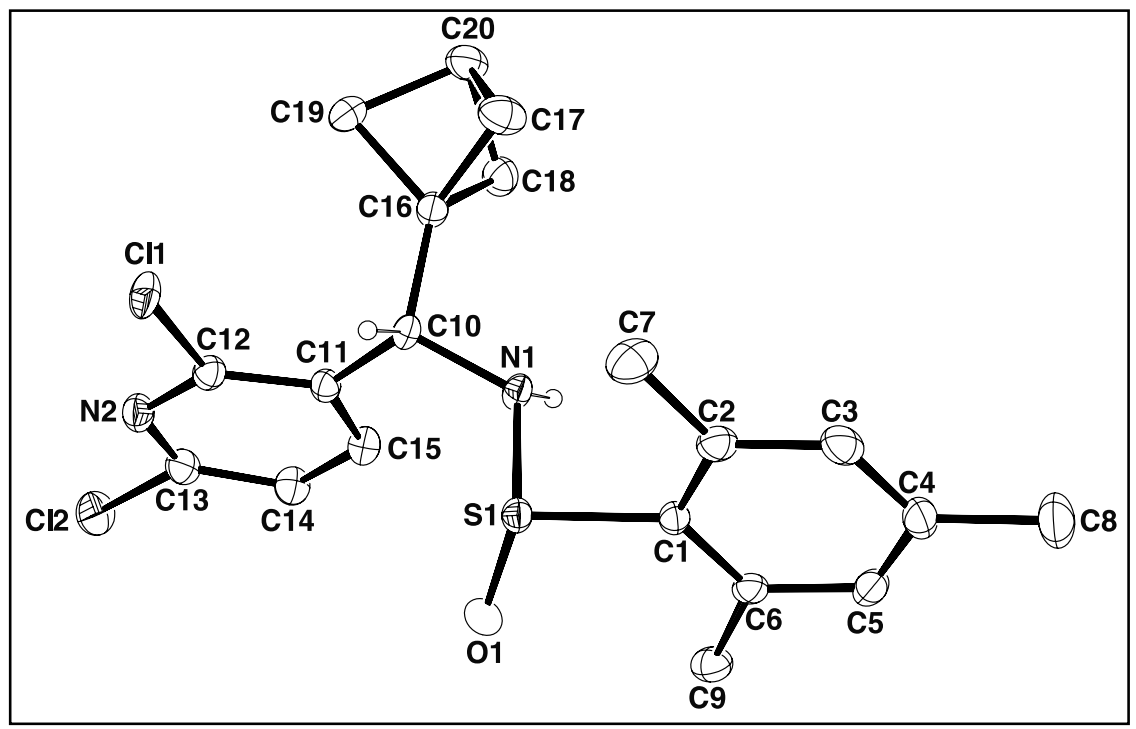


Figure S16. ORTEP drawing of molecule no. 1 of the asymmetric unit with 50\% thermal ellipsoids.

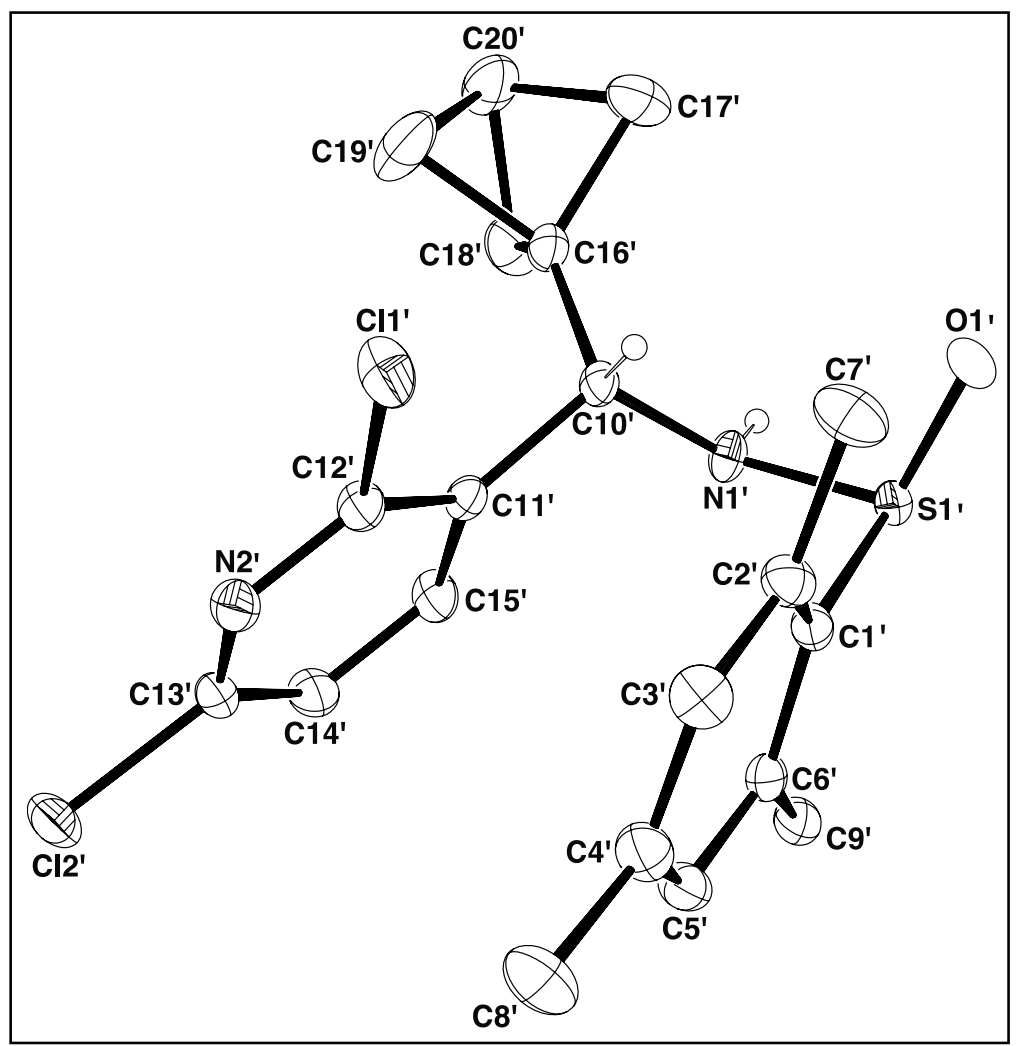

Figure S17. ORTEP drawing of molecule no. 2 of the asymmetric unit with $50 \%$ thermal ellipsoids. 


\section{Table S13. Summary of Structure Determination of Compound 6248}

\begin{tabular}{|c|c|}
\hline Empirical formula & $\mathrm{C}_{20} \mathrm{H}_{22} \mathrm{Cl}_{2} \mathrm{~N}_{2} \mathrm{OS}$ \\
\hline Formula weight & 409.35 \\
\hline Diffractometer & Rigaku XtaLAB Synergy-S \\
\hline Temperature/K & $100(2)$ \\
\hline Crystal system & orthorhombic \\
\hline Space group & $\mathrm{P} 2{ }_{1} 2_{1} 2_{1}$ \\
\hline a & $13.3677(3) \AA ̊$ \\
\hline$b$ & $14.0012(3) \AA$ \\
\hline c & $21.3224(5) \AA$ \\
\hline Volume & $3990.78(16) \AA^{3}$ \\
\hline Z & 8 \\
\hline$d_{\text {calc }}$ & $1.363 \mathrm{~g} / \mathrm{cm}^{3}$ \\
\hline$\mu$ & $0.442 \mathrm{~mm}^{-1}$ \\
\hline$F(000)$ & 1712.0 \\
\hline Crystal size, mm & $0.18 \times 0.16 \times 0.08$ \\
\hline $2 \theta$ range for data collection & $4.626-56.56^{\circ}$ \\
\hline Index ranges & $-17 \leq h \leq 17,-18 \leq k \leq 18,-28 \leq \mathrm{I} \leq 28$ \\
\hline Reflections collected & 81641 \\
\hline Independent reflections & $9897[R($ int $)=0.0466]$ \\
\hline Data/restraints/parameters & $9897 / 0 / 475$ \\
\hline Goodness-of-fit on $\mathrm{F}^{2}$ & 1.034 \\
\hline Final $R$ indexes $[I>=2 \sigma(I)]$ & $\mathrm{R}_{1}=0.0250, \mathrm{w} \mathrm{R}_{2}=0.0610$ \\
\hline Final $R$ indexes [all data] & $R_{1}=0.0270, w R_{2}=0.0616$ \\
\hline
\end{tabular}


Largest diff. peak/hole

Flack parameter
$0.26 /-0.21 \mathrm{e}^{-3}$

$-0.014(12)$ 
Table S14. Refined Positional Parameters for Compound 6248

\begin{tabular}{|c|c|c|c|c|}
\hline Atom & $x$ & $y$ & $z$ & $\mathrm{U}(\mathrm{eq})$ \\
\hline $\mathrm{Cl} 1$ & $0.37325(4)$ & $1.01551(3)$ & $0.61261(2)$ & $0.02303(10)$ \\
\hline $\mathrm{Cl} 2$ & $0.01318(4)$ & $0.91280(4)$ & $0.67232(3)$ & $0.02867(12)$ \\
\hline S1 & $0.50555(3)$ & $0.71120(3)$ & $0.70126(2)$ & $0.01582(9)$ \\
\hline 01 & $0.42176(11)$ & $0.69141(11)$ & $0.74513(7)$ & $0.0239(3)$ \\
\hline N1 & $0.46960(11)$ & $0.71205(11)$ & $0.62612(7)$ & $0.0155(3)$ \\
\hline N2 & $0.19874(12)$ & $0.94815(12)$ & $0.64230(8)$ & $0.0202(3)$ \\
\hline C1 & $0.58390(13)$ & $0.60664(13)$ & $0.69462(8)$ & $0.0149(3)$ \\
\hline C2 & $0.68003(14)$ & $0.62470(14)$ & $0.66980(9)$ & $0.0196(4)$ \\
\hline C3 & $0.74725(15)$ & $0.54912(16)$ & $0.66635(9)$ & $0.0233(4)$ \\
\hline C4 & $0.72271(16)$ & $0.45789(16)$ & $0.68649(9)$ & $0.0239(4)$ \\
\hline C5 & $0.62723(16)$ & $0.44225(14)$ & $0.71045(9)$ & $0.0215(4)$ \\
\hline C6 & $0.55626(14)$ & $0.51550(14)$ & $0.71517(8)$ & $0.0169(4)$ \\
\hline C7 & $0.71103(16)$ & $0.72289(17)$ & $0.64747(11)$ & $0.0280(5)$ \\
\hline C8 & $0.7977(2)$ & $0.37736(19)$ & $0.68333(12)$ & $0.0378(6)$ \\
\hline C9 & $0.45538(15)$ & $0.49110(15)$ & $0.74298(9)$ & $0.0223(4)$ \\
\hline C10 & $0.43201(13)$ & $0.80395(13)$ & $0.60286(9)$ & $0.0148(3)$ \\
\hline C11 & $0.32520(14)$ & $0.82789(13)$ & $0.62256(8)$ & $0.0155(3)$ \\
\hline C12 & $0.29117(14)$ & $0.92161(14)$ & $0.62722(9)$ & $0.0175(4)$ \\
\hline C13 & $0.13471(14)$ & $0.87844(15)$ & $0.65349(9)$ & $0.0204(4)$ \\
\hline C14 & $0.15762(14)$ & $0.78189(15)$ & $0.65114(10)$ & $0.0211(4)$ \\
\hline C15 & $0.25489(14)$ & $0.75738(14)$ & $0.63553(9)$ & $0.0194(4)$ \\
\hline
\end{tabular}




\begin{tabular}{|c|c|c|c|c|}
\hline C16 & $0.44020(14)$ & $0.80179(14)$ & $0.53180(9)$ & $0.0167(4)$ \\
\hline C17 & $0.53761(15)$ & $0.79198(18)$ & $0.49219(10)$ & $0.0264(4)$ \\
\hline C18 & $0.39289(15)$ & $0.72589(14)$ & $0.48783(9)$ & $0.0224(4)$ \\
\hline E19 & $0.40482(16)$ & $0.87828(15)$ & $0.48355(9)$ & $0.0231(4)$ \\
\hline C20 & $0.45004(15)$ & $0.79594(16)$ & $0.44416(9)$ & $0.0237(4)$ \\
\hline $\mathrm{Cl} 1^{\prime}$ & $0.01910(3)$ & $0.36007(4)$ & $0.52428(3)$ & $0.02641(12)$ \\
\hline $\mathrm{Cl} 2^{\prime}$ & $0.07751(4)$ & $-0.00533(4)$ & $0.49982(3)$ & $0.03038(12)$ \\
\hline$S 1^{\prime}$ & $0.36777(3)$ & $0.44685(3)$ & $0.59432(2)$ & $0.01522(9)$ \\
\hline O1' & $0.33401(10)$ & $0.54853(10)$ & $0.59456(7)$ & $0.0210(3)$ \\
\hline N1' & $0.34542(11)$ & $0.39598(12)$ & $0.52594(7)$ & $0.0163(3)$ \\
\hline N2' & $0.06555(11)$ & $0.18006(12)$ & $0.51173(8)$ & $0.0207(3)$ \\
\hline C1' & $0.27770(14)$ & $0.37790(13)$ & $0.63823(9)$ & $0.0161(4)$ \\
\hline$C 2^{\prime}$ & $0.18185(15)$ & $0.40981(14)$ & $0.65563(9)$ & $0.0194(4)$ \\
\hline C3' & $0.11854(15)$ & $0.34371(15)$ & $0.68428(9)$ & $0.0229(4)$ \\
\hline C4' & $0.14688(15)$ & $0.25017(15)$ & $0.69671(10)$ & $0.0229(4)$ \\
\hline C5' & $0.24412(15)$ & $0.22277(14)$ & $0.68233(9)$ & $0.0207(4)$ \\
\hline C6' & $0.31085(14)$ & $0.28498(14)$ & $0.65336(8)$ & $0.0171(4)$ \\
\hline $\mathrm{C7}^{\prime}$ & $0.14256(16)$ & $0.51054(15)$ & $0.64700(11)$ & $0.0279(5)$ \\
\hline C8' & $0.07410(18)$ & $0.18112(17)$ & $0.72622(12)$ & $0.0320(5)$ \\
\hline C9' & $0.41551(14)$ & $0.25070(14)$ & $0.63796(10)$ & $0.0204(4)$ \\
\hline C10' & $0.24523(13)$ & $0.39140(13)$ & $0.49785(9)$ & $0.0148(3)$ \\
\hline C11' & $0.20454(13)$ & $0.29001(13)$ & $0.50053(8)$ & $0.0154(3)$ \\
\hline C12' & $0.10429(13)$ & $0.26787(14)$ & $0.51104(9)$ & $0.0180(4)$ \\
\hline C13' & $0.12850(15)$ & $0.10911(13)$ & $0.50018(10)$ & $0.0207(4)$ \\
\hline
\end{tabular}




\begin{tabular}{|lllll}
$C 14^{\prime}$ & $0.22960(14)$ & $0.12054(14)$ & $0.48855(10)$ & $0.0216(4)$ \\
$C 15^{\prime}$ & $0.26694(13)$ & $0.21232(14)$ & $0.48916(9)$ & $0.0194(4)$ \\
$C 16^{\prime}$ & $0.24946(14)$ & $0.42629(14)$ & $0.43058(9)$ & $0.0181(4)$ \\
$C 17^{\prime}$ & $0.27126(18)$ & $0.53017(16)$ & $0.40903(11)$ & $0.0292(5)$ \\
$C 18^{\prime}$ & $0.32131(18)$ & $0.39329(16)$ & $0.37755(10)$ & $0.0288(5)$ \\
$C 19^{\prime}$ & $0.16368(18)$ & $0.4241(2)$ & $0.38158(11)$ & $0.0392(6)$ \\
$C 20^{\prime}$ & $0.25399(18)$ & $0.47189(18)$ & $0.34814(10)$ & $0.0320(5)$ \\
\hline
\end{tabular}


Table S15. Positional Parameters for Hydrogens in Compound 6248

\begin{tabular}{|c|c|c|c|c|}
\hline Atom & $x$ & $y$ & $z$ & $U(e q)$ \\
\hline $\mathrm{H} 1$ & 0.4287 & 0.660801 & 0.6146 & 0.021 \\
\hline H3 & 0.812092 & 0.560325 & 0.649672 & 0.028 \\
\hline H5 & 0.609635 & 0.379857 & 0.72404 & 0.026 \\
\hline $\mathrm{H} 7 \mathrm{a}$ & 0.782054 & 0.722125 & 0.636104 & 0.042 \\
\hline $\mathrm{H} 7 \mathrm{~b}$ & 0.700042 & 0.76945 & 0.681091 & 0.042 \\
\hline H7c & 0.671063 & 0.740701 & 0.610758 & 0.042 \\
\hline $\mathrm{H} 8 \mathrm{~A}$ & 0.814206 & 0.364133 & 0.639405 & 0.057 \\
\hline $\mathrm{H} 8 \mathrm{~B}$ & 0.76895 & 0.319998 & 0.702558 & 0.057 \\
\hline $\mathrm{H} 8 \mathrm{C}$ & 0.858505 & 0.395671 & 0.705986 & 0.057 \\
\hline H9a & 0.448015 & 0.421544 & 0.745239 & 0.034 \\
\hline $\mathrm{H} 9 \mathrm{~b}$ & 0.402338 & 0.517704 & 0.716497 & 0.034 \\
\hline H9c & 0.450414 & 0.518238 & 0.785232 & 0.034 \\
\hline $\mathrm{H} 10$ & 0.477067 & 0.855497 & 0.618867 & 0.018 \\
\hline $\mathrm{H} 14$ & 0.108655 & 0.734547 & 0.659864 & 0.025 \\
\hline $\mathrm{H} 15$ & 0.273691 & 0.692002 & 0.633681 & 0.023 \\
\hline $\mathrm{H} 17 \mathrm{a}$ & 0.583172 & 0.847724 & 0.492576 & 0.032 \\
\hline $\mathrm{H} 17 \mathrm{~b}$ & 0.573234 & 0.730196 & 0.495519 & 0.032 \\
\hline $\mathrm{H} 18 \mathrm{a}$ & 0.319026 & 0.726877 & 0.484553 & 0.027 \\
\hline $\mathrm{H} 18 \mathrm{~b}$ & 0.420679 & 0.660525 & 0.490951 & 0.027 \\
\hline $\mathrm{H} 19 \mathrm{a}$ & 0.3316 & 0.887393 & 0.479949 & 0.028 \\
\hline $\mathrm{H} 19 \mathrm{~b}$ & 0.442514 & 0.939143 & 0.483357 & 0.028 \\
\hline
\end{tabular}




\begin{tabular}{|c|c|c|c|c|}
\hline $\mathrm{H} 2 \mathrm{O}$ & 0.455222 & 0.792607 & 0.397428 & 0.028 \\
\hline $\mathrm{H} 1^{\prime}$ & 0.399301 & 0.4136 & 0.5023 & 0.022 \\
\hline H3' & 0.05312 & 0.363565 & 0.695808 & 0.027 \\
\hline $\mathrm{H} 5^{\prime}$ & 0.265574 & 0.159977 & 0.69254 & 0.025 \\
\hline H7a' & 0.180581 & 0.554445 & 0.673701 & 0.042 \\
\hline H7b' & 0.071709 & 0.512754 & 0.658705 & 0.042 \\
\hline $\mathrm{H} 7 \mathrm{c}^{\prime}$ & 0.150004 & 0.529521 & 0.603006 & 0.042 \\
\hline H8a' & 0.00566 & 0.199065 & 0.714716 & 0.048 \\
\hline H8b' & 0.0813 & 0.183115 & 0.771941 & 0.048 \\
\hline $\mathrm{H} 8 \mathrm{c}^{\prime}$ & 0.088089 & 0.116351 & 0.71117 & 0.048 \\
\hline H9a' & 0.463957 & 0.300558 & 0.648822 & 0.031 \\
\hline H9b' & 0.420085 & 0.236599 & 0.59303 & 0.031 \\
\hline H9c' & 0.430179 & 0.192771 & 0.662058 & 0.031 \\
\hline $\mathrm{H} 10^{\prime}$ & 0.199501 & 0.434129 & 0.522152 & 0.018 \\
\hline H14' & 0.271652 & 0.067243 & 0.480471 & 0.026 \\
\hline H15' & 0.336157 & 0.222679 & 0.481714 & 0.023 \\
\hline H17a' & 0.2195 & 0.578235 & 0.419355 & 0.035 \\
\hline $\mathrm{H}^{\prime} 17 \mathrm{~b}^{\prime}$ & 0.34023 & 0.55357 & 0.416077 & 0.035 \\
\hline H18a' & 0.392757 & 0.409911 & 0.383054 & 0.035 \\
\hline H18b' & 0.31108 & 0.327574 & 0.361656 & 0.035 \\
\hline H19a' & 0.105685 & 0.466015 & 0.390342 & 0.047 \\
\hline H19b' & 0.144104 & 0.360211 & 0.365939 & 0.047 \\
\hline $\mathrm{H} 2 \mathrm{O}^{\prime}$ & 0.256341 & 0.496251 & 0.304075 & 0.038 \\
\hline
\end{tabular}


Table S16. Refined Thermal Parameters (U's) for Compound 6248

\begin{tabular}{|c|c|c|c|c|c|c|}
\hline Atom & $\mathbf{U}_{11}$ & $U_{22}$ & $U_{33}$ & $U_{23}$ & $U_{13}$ & $U_{12}$ \\
\hline $\mathrm{Cl} 1$ & $0.0249(2)$ & $0.0110(2)$ & $0.0331(3)$ & $-0.00010(18)$ & $0.0002(2)$ & $-0.00010(17)$ \\
\hline $\mathrm{Cl} 2$ & $0.0191(2)$ & $0.0324(3)$ & $0.0345(3)$ & $0.0019(2)$ & $0.0038(2)$ & $0.0089(2)$ \\
\hline S1 & $0.0184(2)$ & $0.0135(2)$ & $0.01555(19)$ & $-0.00142(17)$ & $-0.00190(17)$ & $0.00236(17)$ \\
\hline $\mathrm{O} 1$ & $0.0251(7)$ & $0.0273(8)$ & $0.0194(7)$ & $0.0000(6)$ & $0.0049(6)$ & $0.0075(6)$ \\
\hline N1 & $0.0185(7)$ & $0.0112(7)$ & $0.0167(7)$ & $-0.0001(6)$ & $-0.0039(6)$ & $0.0008(6)$ \\
\hline N2 & $0.0219(8)$ & $0.0182(8)$ & $0.0205(8)$ & $-0.0015(7)$ & $-0.0021(6)$ & $0.0047(7)$ \\
\hline $\mathrm{C} 1$ & $0.0173(8)$ & $0.0144(8)$ & $0.0131(8)$ & $-0.0010(7)$ & $-0.0021(7)$ & $0.0027(7)$ \\
\hline $\mathrm{C} 2$ & $0.0206(9)$ & $0.0226(10)$ & $0.0156(8)$ & $0.0019(8)$ & $-0.0013(7)$ & $0.0007(7)$ \\
\hline C3 & $0.0183(9)$ & $0.0332(11)$ & $0.0185(9)$ & $0.0006(9)$ & $0.0011(7)$ & $0.0061(8)$ \\
\hline C4 & $0.0291(10)$ & $0.0260(11)$ & $0.0167(9)$ & $-0.0039(8)$ & $-0.0047(8)$ & $0.0121(9)$ \\
\hline C5 & $0.0341(10)$ & $0.0144(9)$ & $0.0159(9)$ & $-0.0003(7)$ & $-0.0053(8)$ & $0.0032(8)$ \\
\hline C6 & $0.0226(9)$ & $0.0163(9)$ & $0.0118(8)$ & $-0.0003(7)$ & $-0.0015(7)$ & $-0.0006(7)$ \\
\hline C7 & $0.0224(10)$ & $0.0301(12)$ & $0.0315(11)$ & $0.0083(9)$ & $0.0028(9)$ & $-0.0042(9)$ \\
\hline $\mathrm{C} 8$ & $0.0450(14)$ & $0.0378(14)$ & $0.0307(12)$ & $-0.0061(10)$ & $-0.0055(10)$ & $0.0251(11)$ \\
\hline C9 & $0.0269(10)$ & $0.0208(10)$ & $0.0193(9)$ & $0.0019(8)$ & $0.0014(8)$ & $-0.0040(8)$ \\
\hline C10 & $0.0163(8)$ & $0.0106(8)$ & $0.0174(8)$ & $0.0004(7)$ & $-0.0015(7)$ & $0.0007(6)$ \\
\hline C11 & $0.0174(8)$ & $0.0146(9)$ & $0.0146(8)$ & $-0.0013(7)$ & $-0.0022(7)$ & $0.0018(7)$ \\
\hline C12 & $0.0203(9)$ & $0.0153(9)$ & $0.0170(9)$ & $-0.0002(7)$ & $-0.0017(7)$ & $-0.0002(7)$ \\
\hline C13 & $0.0169(8)$ & $0.0252(10)$ & $0.0193(9)$ & $0.0005(8)$ & $-0.0008(7)$ & $0.0065(8)$ \\
\hline C14 & $0.0182(9)$ & $0.0205(10)$ & $0.0247(10)$ & $0.0000(8)$ & $0.0006(7)$ & $-0.0004(7)$ \\
\hline C15 & $0.0189(9)$ & $0.0166(9)$ & $0.0229(10)$ & $-0.0004(8)$ & $-0.0018(8)$ & $0.0011(7)$ \\
\hline C16 & $0.0179(8)$ & $0.0148(9)$ & $0.0174(8)$ & $-0.0001(7)$ & $-0.0009(7)$ & $0.0015(7)$ \\
\hline
\end{tabular}




\begin{tabular}{|c|c|c|c|c|c|c|}
\hline C17 & $0.0203(9)$ & $0.0377(12)$ & $0.0213(10)$ & $0.0015(9)$ & $0.0011(8)$ & $0.0016(8)$ \\
\hline C18 & $0.0271(10)$ & $0.0195(10)$ & $0.0207(10)$ & $-0.0023(8)$ & $-0.0025(8)$ & $0.0014(8)$ \\
\hline C19 & $0.0302(10)$ & $0.0194(10)$ & $0.0197(9)$ & $0.0047(8)$ & $0.0003(8)$ & $0.0018(8)$ \\
\hline C20 & $0.0229(9)$ & $0.0310(11)$ & $0.0171(9)$ & $0.0017(9)$ & $0.0011(7)$ & $0.0037(9)$ \\
\hline $\mathrm{Cl} 1^{\prime}$ & $0.01130(19)$ & $0.0217(2)$ & $0.0463(3)$ & $-0.0061(2)$ & $0.0009(2)$ & $0.00155(17)$ \\
\hline $\mathrm{Cl} 2^{\prime}$ & $0.0248(2)$ & $0.0162(2)$ & $0.0501(3)$ & $0.0077(2)$ & $-0.0091(2)$ & $-0.00471(18)$ \\
\hline$S 1^{\prime}$ & $0.01521(19)$ & $0.0135(2)$ & $0.0169(2)$ & $-0.00086(17)$ & $-0.00230(17)$ & $-0.00251(16)$ \\
\hline $01^{\prime}$ & $0.0253(7)$ & $0.0124(6)$ & $0.0254(7)$ & $-0.0012(6)$ & $-0.0005(6)$ & $-0.0018(5)$ \\
\hline N1' & $0.0110(7)$ & $0.0216(8)$ & $0.0162(7)$ & $-0.0028(6)$ & $-0.0012(6)$ & $-0.0024(6)$ \\
\hline N2' & $0.0143(7)$ & $0.0207(8)$ & $0.0272(9)$ & $0.0027(7)$ & $-0.0025(7)$ & $-0.0020(6)$ \\
\hline$C 1^{\prime}$ & $0.0188(8)$ & $0.0152(9)$ & $0.0143(8)$ & $-0.0011(7)$ & $0.0000(7)$ & $-0.0033(7)$ \\
\hline C2' & $0.0228(9)$ & $0.0164(9)$ & $0.0190(9)$ & $-0.0013(7)$ & $0.0014(7)$ & $0.0014(7)$ \\
\hline C3' & $0.0207(9)$ & $0.0249(10)$ & $0.0230(10)$ & $-0.0012(8)$ & $0.0050(8)$ & $0.0008(8)$ \\
\hline C4' & $0.0274(10)$ & $0.0223(10)$ & $0.0190(9)$ & $-0.0004(8)$ & $0.0039(8)$ & $-0.0039(8)$ \\
\hline C5' & $0.0277(10)$ & $0.0154(9)$ & $0.0191(9)$ & $0.0009(7)$ & $0.0003(8)$ & $-0.0006(8)$ \\
\hline C6' & $0.0222(9)$ & $0.0147(9)$ & $0.0145(8)$ & $-0.0034(7)$ & $-0.0027(7)$ & $0.0003(7)$ \\
\hline $\mathrm{C7}^{\prime}$ & $0.0264(10)$ & $0.0190(10)$ & $0.0384(12)$ & $0.0008(9)$ & $0.0072(9)$ & $0.0054(8)$ \\
\hline C8' & $0.0335(12)$ & $0.0254(11)$ & $0.0370(12)$ & $0.0044(10)$ & $0.0083(10)$ & $-0.0070(9)$ \\
\hline C9' & $0.0210(9)$ & $0.0158(9)$ & $0.0245(10)$ & $-0.0004(8)$ & $-0.0040(8)$ & $0.0012(7)$ \\
\hline C10' & $0.0107(7)$ & $0.0156(9)$ & $0.0181(9)$ & $-0.0013(7)$ & $-0.0023(7)$ & $0.0001(6)$ \\
\hline C11' & $0.0130(8)$ & $0.0179(9)$ & $0.0153(8)$ & $0.0001(7)$ & $-0.0022(7)$ & $-0.0004(7)$ \\
\hline C12' & $0.0131(8)$ & $0.0180(9)$ & $0.0228(9)$ & $-0.0005(7)$ & $-0.0015(7)$ & $0.0011(7)$ \\
\hline C13' & $0.0196(8)$ & $0.0156(9)$ & $0.0269(10)$ & $0.0040(8)$ & $-0.0062(8)$ & $-0.0044(7)$ \\
\hline C14' & $0.0181(9)$ & 0.0170(9) & $0.0296(11)$ & $0.0009(8)$ & $-0.0030(8)$ & $0.0036(7)$ \\
\hline
\end{tabular}




$\mid$\begin{tabular}{lllllll}
$C 15^{\prime}$ & $0.0113(8)$ & $0.0204(9)$ & $0.0264(10)$ & $-0.0014(8)$ & $-0.0001(7)$ & $0.0001(7)$ \\
$C 16^{\prime}$ & $0.0166(8)$ & $0.0195(10)$ & $0.0183(9)$ & $0.0007(7)$ & $-0.0030(7)$ & $-0.0036(7)$ \\
$C 17^{\prime}$ & $0.0375(12)$ & $0.0216(11)$ & $0.0285(11)$ & $0.0055(9)$ & $0.0048(9)$ & $0.0001(9)$ \\
$C 18^{\prime}$ & $0.0379(12)$ & $0.0264(11)$ & $0.0220(10)$ & $-0.0034(9)$ & $0.0056(9)$ & $-0.0029(9)$ \\
$C 19$ & $0.0297(11)$ & $0.0637(18)$ & $0.0241(11)$ & $0.0144(11)$ & $-0.0098(9)$ & $-0.0144(11)$ \\
$C 20^{\prime}$ & $0.0346(11)$ & $0.0416(14)$ & $0.0199(10)$ & $0.0087(10)$ & $-0.0037(9)$ & $-0.0107(10)$ \\
\hline
\end{tabular}


Table S17. Bond Distances in Compound 6248, $\AA$

\begin{tabular}{|c|c|c|c|c|c|}
\hline $\mathrm{Cl} 1-\mathrm{C} 12$ & $1.741(2)$ & $\mathrm{Cl} 2-\mathrm{C} 13$ & $1.741(2)$ & S1-O1 & $1.4852(15)$ \\
\hline S1-N1 & $1.6729(16)$ & $\mathrm{S} 1-\mathrm{C} 1$ & $1.8055(19)$ & N1-C10 & $1.468(2)$ \\
\hline $\mathrm{N} 2-\mathrm{C} 12$ & $1.330(3)$ & $\mathrm{N} 2-\mathrm{C} 13$ & $1.320(3)$ & $\mathrm{C} 1-\mathrm{C} 2$ & $1.413(3)$ \\
\hline C1-C6 & $1.399(3)$ & $\mathrm{C} 2-\mathrm{C} 3$ & $1.390(3)$ & $\mathrm{C} 2-\mathrm{C} 7$ & $1.513(3)$ \\
\hline C3-C4 & $1.387(3)$ & C4-C5 & $1.392(3)$ & $\mathrm{C} 4-\mathrm{C} 8$ & $1.510(3)$ \\
\hline C5-C6 & $1.401(3)$ & C6-C9 & $1.512(3)$ & C10-C11 & $1.526(2)$ \\
\hline C10-C16 & $1.520(3)$ & C11-C12 & $1.392(3)$ & C11-C15 & $1.391(3)$ \\
\hline C13-C14 & $1.387(3)$ & C14-C15 & $1.385(3)$ & $\mathrm{C} 16-\mathrm{C} 17$ & $1.558(3)$ \\
\hline C16-C18 & $1.552(3)$ & C16-C19 & $1.559(3)$ & C17-C20 & $1.556(3)$ \\
\hline C18-C20 & $1.553(3)$ & C19-C20 & $1.549(3)$ & $\mathrm{Cl} 1^{\prime}-\mathrm{C} 12^{\prime}$ & $1.7444(19)$ \\
\hline $\mathrm{Cl} 2^{\prime}-\mathrm{C} 13^{\prime}$ & $1.7412(19)$ & S1'-O1' & $1.4935(14)$ & S1'-N1' & $1.6501(16)$ \\
\hline$S 1^{\prime}-C 1^{\prime}$ & $1.8051(19)$ & N1'-C10' & $1.468(2)$ & N2'-C12' & $1.334(3)$ \\
\hline N2'-C13' & $1.325(3)$ & $C 1^{\prime}-C 2^{\prime}$ & $1.407(3)$ & $\mathrm{C} 1^{\prime}-\mathrm{C} 6^{\prime}$ & $1.412(3)$ \\
\hline$C 2^{\prime}-C 3^{\prime}$ & $1.395(3)$ & $C 2^{\prime}-C 7^{\prime}$ & $1.516(3)$ & C3'-C4' & $1.389(3)$ \\
\hline$C 4^{\prime}-C 5^{\prime}$ & $1.390(3)$ & C4'-C8' & $1.509(3)$ & C5'-C6' & $1.392(3)$ \\
\hline C6'-C9' & $1.515(3)$ & C10'-C11' & $1.521(3)$ & C10'-C16' & $1.516(3)$ \\
\hline C11'-C12' & ' $1.394(2)$ & C11'-C15' & $1.392(3)$ & C13'-C14' & $1.383(3)$ \\
\hline C14'-C15' & ' $1.379(3)$ & C16'-C17' & $1.553(3)$ & C16'-C18' & $1.554(3)$ \\
\hline C16'-C19' & $1.552(3)$ & C17'-C20' & $1.551(3)$ & C18'-C20' & $1.554(3)$ \\
\hline C19'-C20' & ' $1.554(3)$ & & & & \\
\hline
\end{tabular}


Table S18. Bond Angles in Compound 6248,

\begin{tabular}{|c|c|c|c|c|c|}
\hline O1-S1-N1 & $112.82(8)$ & O1-S1-C1 & 109.61(9) & N1-S1-C1 & $95.58(8)$ \\
\hline C10-N1-S1 & $115.35(12)$ & C13-N2-C12 & $116.08(17)$ & C2-C1-S1 & $114.33(14)$ \\
\hline C6-C1-S1 & $124.18(14)$ & $\mathrm{C} 6-\mathrm{C} 1-\mathrm{C} 2$ & $121.39(17)$ & $\mathrm{C} 1-\mathrm{C} 2-\mathrm{C} 7$ & $121.99(18)$ \\
\hline C3-C2-C1 & $118.14(18)$ & $\mathrm{C} 3-\mathrm{C} 2-\mathrm{C} 7$ & $119.87(18)$ & $\mathrm{C} 4-\mathrm{C} 3-\mathrm{C} 2$ & $122.13(19)$ \\
\hline C3-C4-C5 & $118.38(18)$ & $\mathrm{C} 3-\mathrm{C} 4-\mathrm{C} 8$ & $121.1(2)$ & $\mathrm{C} 5-\mathrm{C} 4-\mathrm{C} 8$ & $120.5(2)$ \\
\hline C4-C5-C6 & $122.15(19)$ & $\mathrm{C} 1-\mathrm{C} 6-\mathrm{C} 5$ & $117.81(18)$ & C1-C6-C9 & $124.36(17)$ \\
\hline C5-C6-C9 & $117.82(18)$ & N1-C10-C11 & $114.84(15)$ & N1-C10-C16 & $107.14(14)$ \\
\hline C16-C10-C11 & $110.26(15)$ & C12-C11-C10 & $122.18(16)$ & C15-C11-C10 & $122.09(16)$ \\
\hline C15-C11-C12 & $115.72(17)$ & $\mathrm{N} 2-\mathrm{C} 12-\mathrm{Cl} 1$ & $114.71(15)$ & N2-C12-C11 & $125.75(18)$ \\
\hline C11-C12-Cl1 & $119.55(15)$ & $\mathrm{N} 2-\mathrm{C} 13-\mathrm{Cl} 2$ & $116.26(15)$ & N2-C13-C14 & $124.82(18)$ \\
\hline $\mathrm{C} 14-\mathrm{C} 13-\mathrm{Cl} 2$ & $118.92(16)$ & C15-C14-C13 & 117.22(19) & C14-C15-C11 & $120.40(18)$ \\
\hline C10-C16-C17 & $127.05(16)$ & $\mathrm{C} 10-\mathrm{C} 16-\mathrm{C} 18$ & $125.93(16)$ & C10-C16-C19 & $128.51(16)$ \\
\hline C17-C16-C19 & $87.50(15)$ & C18-C16-C17 & $87.29(15)$ & C18-C16-C19 & $87.02(14)$ \\
\hline C20-C17-C16 & $74.03(13)$ & $\mathrm{C} 16-\mathrm{C} 18-\mathrm{C} 20$ & $74.30(14)$ & C20-C19-C16 & $74.22(14)$ \\
\hline C18-C20-C17 & $87.31(15)$ & C19-C20-C17 & $87.90(16)$ & C19-C20-C18 & $87.31(15)$ \\
\hline O1'-S1'-N1' & $111.08(8)$ & O1'-S1'-C1' & $107.85(8)$ & N1'-S1'-C1' & $96.13(8)$ \\
\hline C10'-N1'-S1' & $122.98(12)$ & C13'-N2'-C12' & $116.25(16)$ & C2'-C1'-S1' & $125.06(15)$ \\
\hline$C 2^{\prime}-C 1^{\prime}-C 6^{\prime}$ & $121.23(17)$ & C6'-C1'-S1' & $113.70(14)$ & $C 1^{\prime}-C 2^{\prime}-C 7^{\prime}$ & $125.38(18)$ \\
\hline $\mathrm{C} 3^{\prime}-\mathrm{C} 2^{\prime}-\mathrm{C} 1^{\prime}$ & $117.21(18)$ & $\mathrm{C} 3^{\prime}-\mathrm{C} 2^{\prime}-\mathrm{C} 7^{\prime}$ & $117.40(18)$ & $\mathrm{C} 4^{\prime}-\mathrm{C} 3^{\prime}-\mathrm{C} 2^{\prime}$ & $122.94(19)$ \\
\hline C3'-C4'-C5' & $118.25(19)$ & C3'-C4'-C8' & $120.52(19)$ & $\mathrm{C} 5^{\prime}-\mathrm{C} 4^{\prime}-\mathrm{C} 8^{\prime}$ & $121.21(19)$ \\
\hline C4'-C5'-C6' & $121.66(19)$ & C1'-C6'-C9' & $122.16(17)$ & $\mathrm{C} 5^{\prime}-\mathrm{C} 6^{\prime}-\mathrm{C} 1^{\prime}$ & $118.49(17)$ \\
\hline C5'-C6'-C9' & $119.33(17)$ & $\mathrm{N} 1{ }^{\prime}-\mathrm{C} 10^{\prime}-\mathrm{C} 11^{\prime}$ & $110.58(15)$ & N1'-C10'-C16' & $109.73(15)$ \\
\hline
\end{tabular}




\begin{tabular}{|c|c|c|}
\hline C16'-C10'-C11' 110.45(15) & C12'-C11'-C10' 123.88(16) & C15'-C11'-C10' 120.56(15) \\
\hline C15'-C11'-C12' 115.49(17) & N2'-C12'-Cl1' $115.26(13)$ & N2'-C12'-C11' $125.45(17)$ \\
\hline C11'-C12'-Cl1' 119.29(15) & $\mathrm{N} 2{ }^{\prime}-\mathrm{C} 13^{\prime}-\mathrm{Cl} 2$ ' $116.24(15)$ & N2'-C13'-C14' 124.54(18) \\
\hline C14'-C13'-Cl2' 119.22(15) & C15'-C14'-C13' 117.38(18) & C14'-C15'-C11' 120.87(16) \\
\hline C10'-C16'-C17' 126.06(17) & C10'-C16'-C18' 128.00(17) & C10'-C16'-C19' 127.09(17) \\
\hline C17'-C16'-C18' 86.97(15) & C19'-C16'-C17' 87.58(17) & C19'-C16'-C18' 87.76(17) \\
\hline C20'-C17'-C16' 74.16(15) & C20'-C18'-C16' 74.04(15) & C16'-C19'-C20' 74.11(15) \\
\hline C17'-C20'-C18' 87.05(16) & C17'-C20'-C19' 87.59(18) & C19'-C20'-C18' 87.70(18) \\
\hline
\end{tabular}

This report has been created with Olex2 [9], compiled on 2018.05 .29 svn.r3508 for OlexSys. 


\section{References for crystallographic data}

[1] CrysAlisPro 1.171.41.104a: Rigaku Oxford Diffraction, Rigaku Corporation, Oxford, UK. (2020).

[2] CrysAlisPro 1.171.41.104a: Rigaku Oxford Diffraction, Rigaku Corporation, Oxford, UK. (2020).

[3] SCALE3 ABSPACK v1.0.7: an Oxford Diffraction program; Oxford Diffraction Ltd: Abingdon, UK, 2005.

[4] SHELXT v2014/4: Sheldrick, G.M. Acta Cryst. A, 2015, 71, 3-8.

[5] SHELXL-2018/3: Sheldrick, G.M. Acta Cryst. A, 2015, 71, 3-8.

[6] Hooft, R.W.W. Straver, L.H., Spek, A.L. J. Appl. Cryst., 2008, 41, 96-103.

[7] Spek, A.L. Acta Cryst. 2009, D65, 148-155.

[8] Flack, H.D. Acta Cryst. A, 1983, 39, 876-881.

[9] Olex2: Dolomanov,O.V., Bourhis, L.J., Gildea, R.J., Howard, J.A.K., Puschmann, H. J. Appl. Cryst. 2009, 42, 339-341. 
${ }^{1} \mathrm{H}$ NMR spectrum $\left(\left(\mathrm{CDCl}_{3}, 400 \mathrm{MHz}\right)\right.$ of 1-(3-bromopyridin-4-yl)- $\boldsymbol{N}$-(mesityl( $\boldsymbol{\kappa}^{\mathbf{1}}$-oxidaneyl)$\boldsymbol{\Lambda}^{\mathbf{3}}$-sulfaneyl)methanimine (4i)

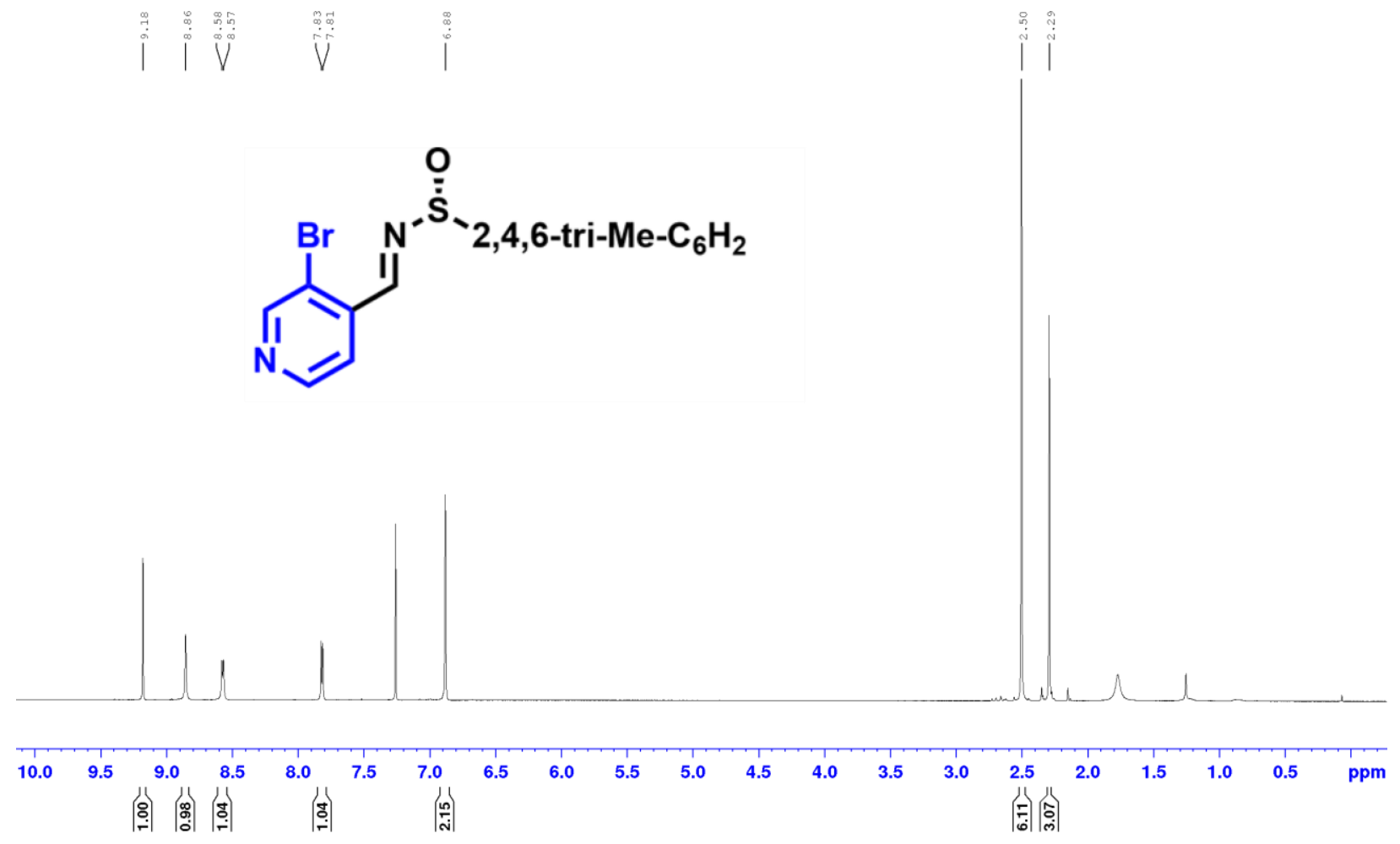


${ }^{13} \mathrm{C}\left\{{ }^{1} \mathrm{H}\right\}$ NMR spectrum $\left(\left(\mathrm{CDCl}_{3}, 100 \mathrm{MHz}\right)\right.$ of $\mathbf{1}$-(3-bromopyridin-4-yl)- $\boldsymbol{N}$-(mesityl $\left(\boldsymbol{\kappa}^{\mathbf{1}}\right.$ oxidaneyl)- $\kappa^{3}$-sulfaneyl)methanimine (4i)

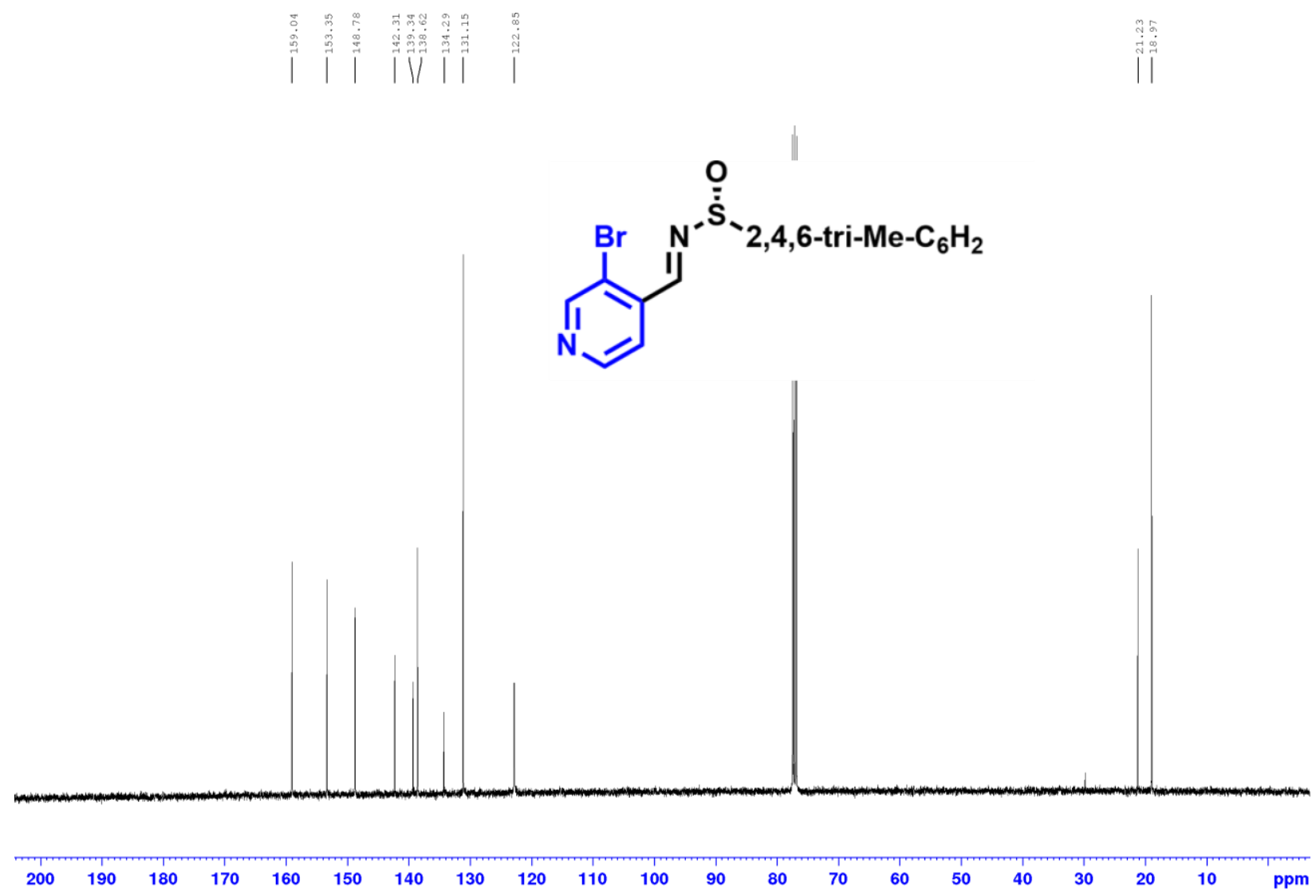


${ }^{1} \mathrm{H}$ NMR spectrum $\left(\left(\mathrm{CDCl}_{3}, 400 \mathrm{MHz}\right)\right.$ of (1-(2-bromopyridin-4-yl)- $N$-(mesityl( $\boldsymbol{K}^{\mathbf{1}}$-oxidaneyl)$\kappa^{3}$-sulfaneyl)methanimine $(4 \mathbf{j})$

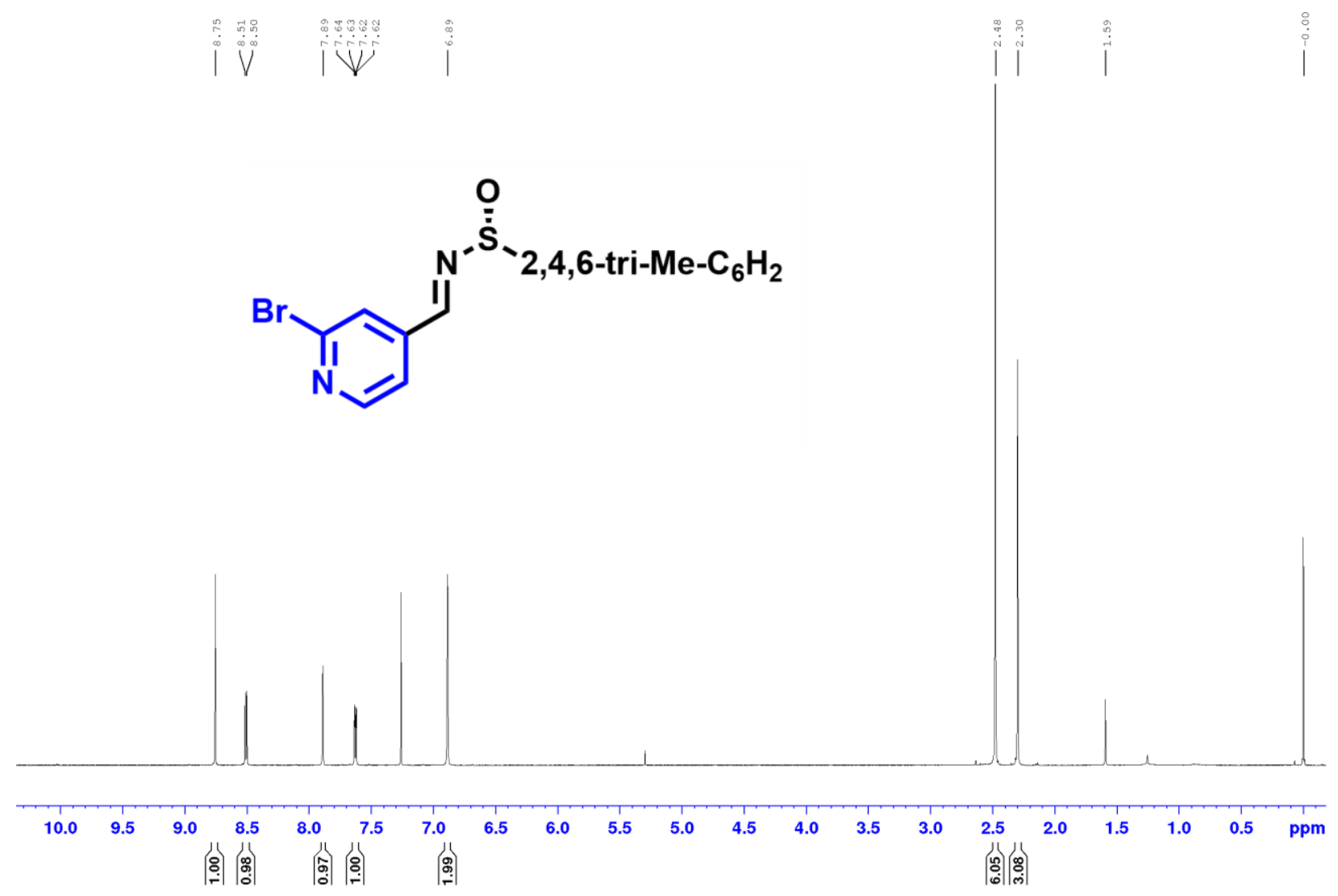


${ }^{13} \mathrm{C}\left\{{ }^{1} \mathrm{H}\right\}$ NMR spectrum $\left(\left(\mathrm{CDCl}_{3}, 100 \mathrm{MHz}\right)\right.$ of (1-(2-bromopyridin-4-yl)- $\mathbf{N}$-(mesityl $\left(\boldsymbol{\Lambda}^{\mathbf{1}}\right.$ oxidaneyl)- $\boldsymbol{~}^{3}$-sulfaneyl)methanimine $(4 \mathbf{j})$

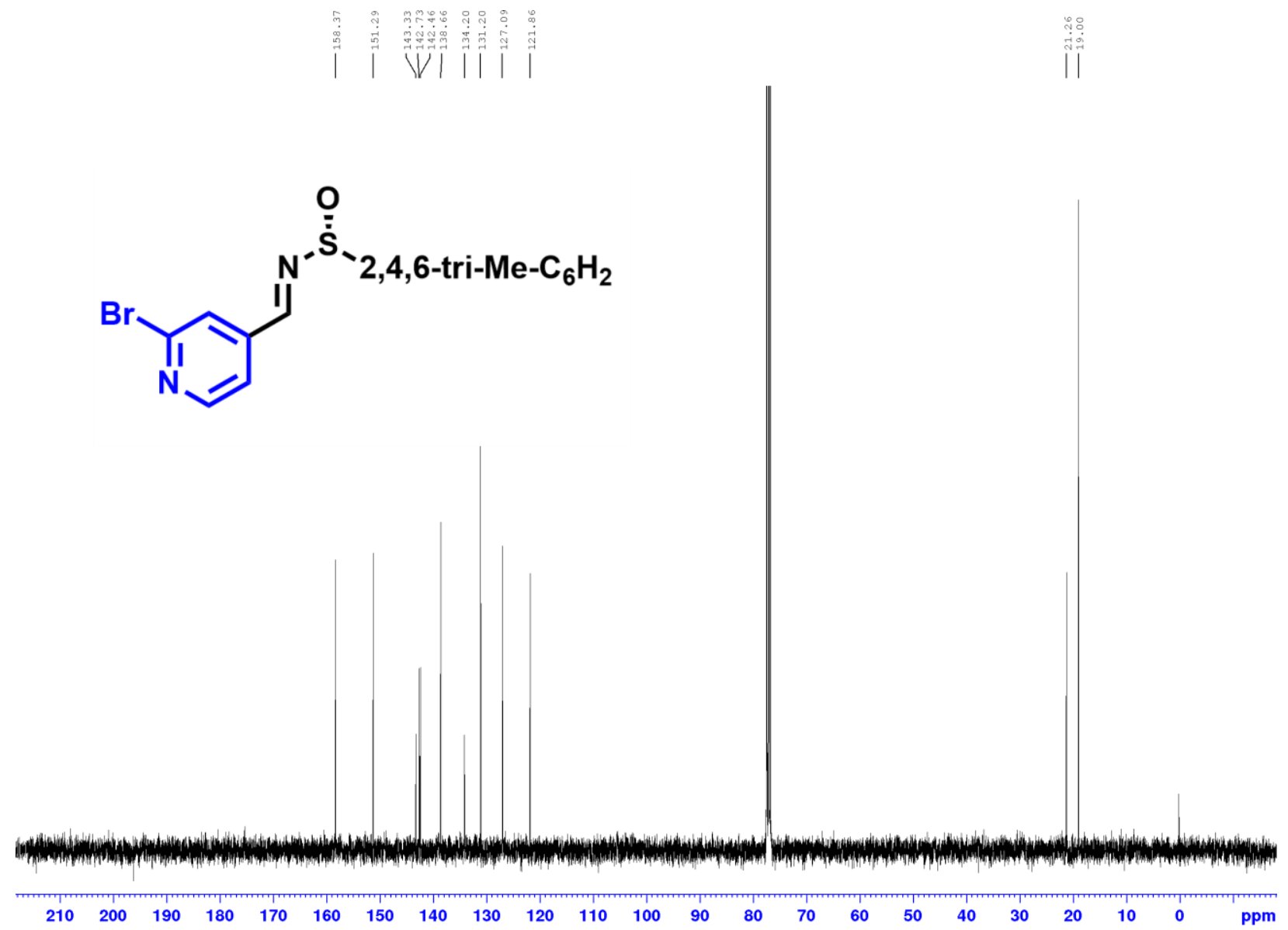


${ }^{1} \mathrm{H}$ NMR spectrum $\left(\left(\mathrm{CDCl}_{3}, 400 \mathrm{MHz}\right)\right.$ of 1-(6-bromopyridin-2-yl)- $\mathbf{N}$-(mesityl( $\boldsymbol{\Lambda}^{\mathbf{3}}$-oxidaneyl)$\boldsymbol{i}^{\mathbf{3}}$-sulfaneyl)methanimine (4k)

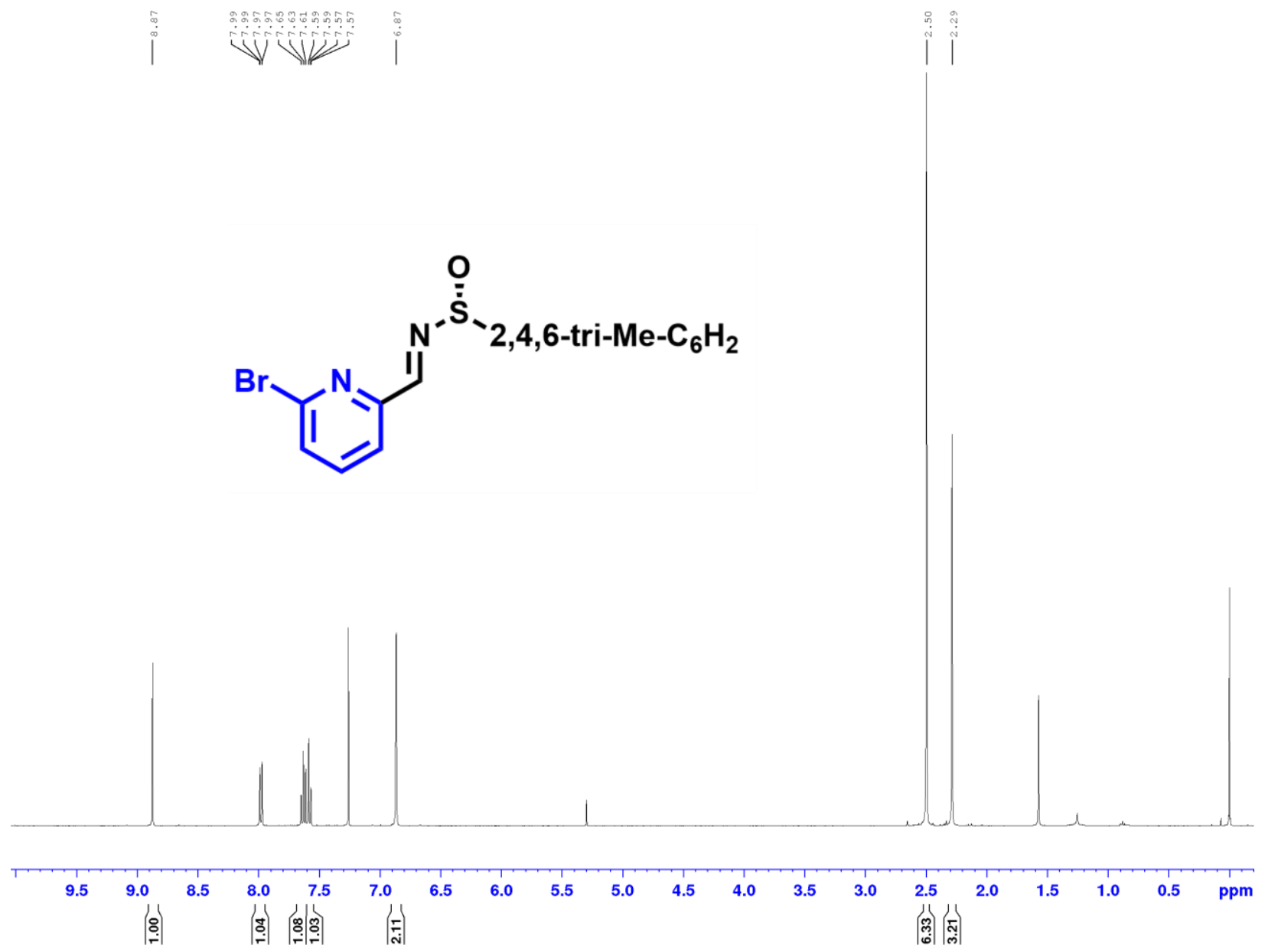


${ }^{13} \mathrm{C}\left\{{ }^{1} \mathrm{H}\right\}$ NMR spectrum $\left(\left(\mathrm{CDCl}_{3}, 100 \mathrm{MHz}\right)\right.$ of 1-(6-bromopyridin-2-yl)- $\boldsymbol{N}$-(mesityl $\left(\boldsymbol{\kappa}^{\mathbf{3}}\right.$ oxidaneyl)- $\boldsymbol{\Lambda}^{3}$-sulfaneyl)methanimine $(4 k)$

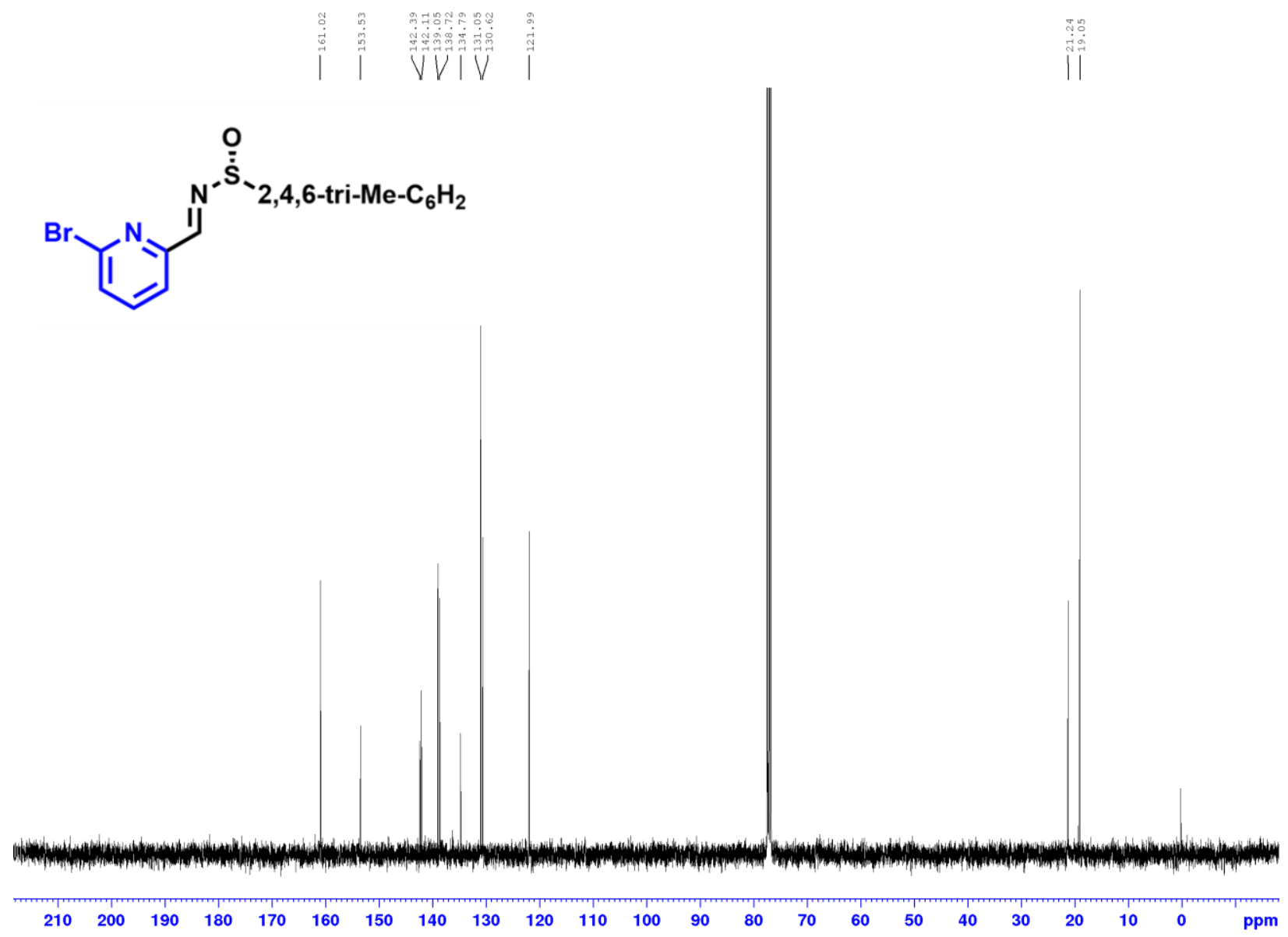


${ }^{1} \mathrm{H}$ NMR spectrum $\left(\left(\mathrm{CDCl}_{3}, 400 \mathrm{MHz}\right)\right.$ of $\mathbf{1}-\left(\left[\mathbf{1}, \mathbf{1}^{\mathbf{1}}\right.\right.$-biphenyl]-4-yl)- $N$-(mesityl( $\boldsymbol{K}^{\mathbf{1}}$-oxidaneyl)- $\boldsymbol{\kappa}^{\mathbf{3}}$ sulfaneyl)methanimine (4b)

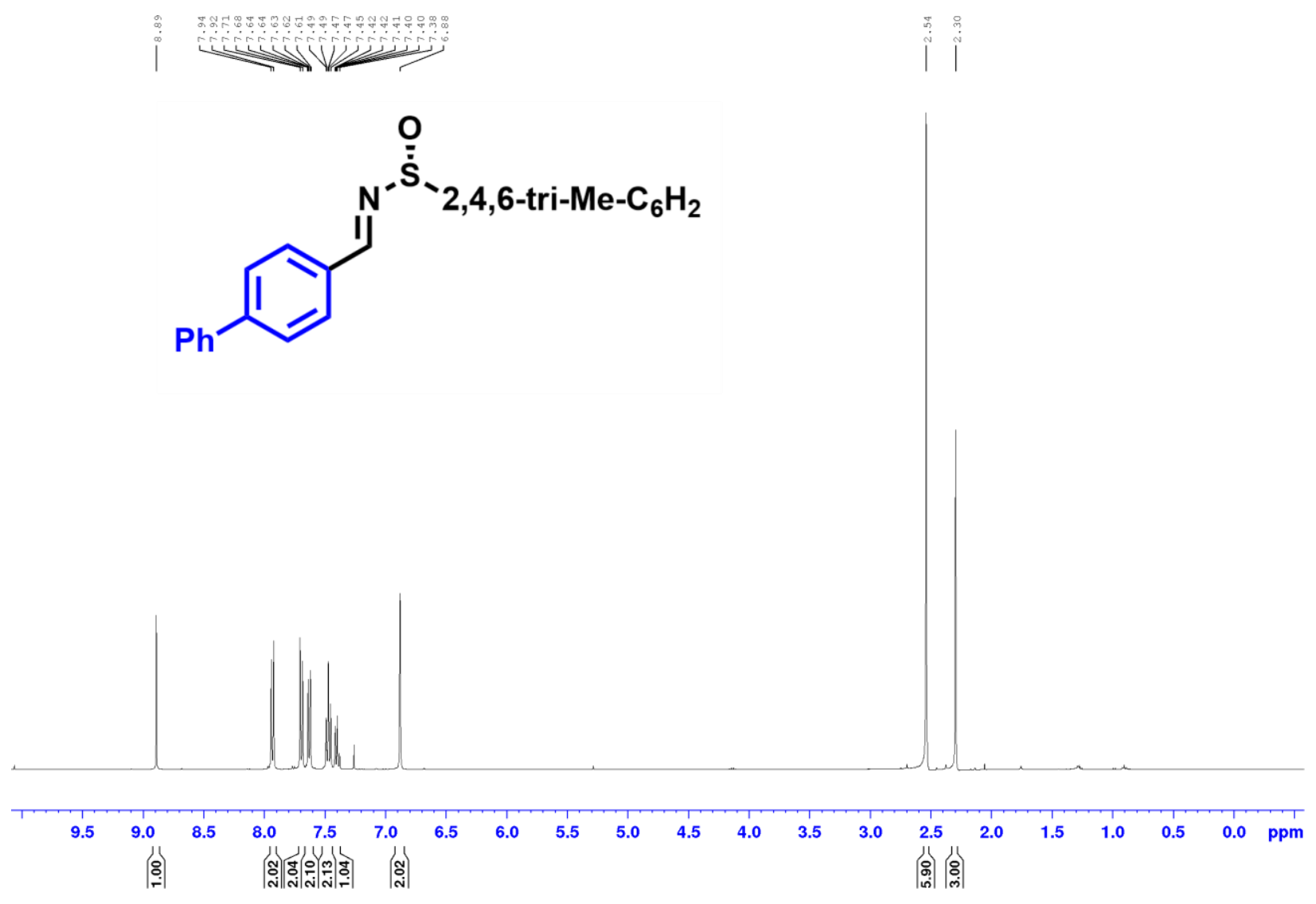


${ }^{13} \mathrm{C}\left\{{ }^{1} \mathrm{H}\right\}$ NMR spectrum $\left(\left(\mathrm{CDCl}_{3}, 100 \mathrm{MHz}\right)\right.$ of $\mathbf{1}-\left(\left[\mathbf{1}, \mathbf{1}^{\prime}\right.\right.$-biphenyl $\left.]-4-\mathbf{y l}\right)-\boldsymbol{N}$-(mesityl $\left(\boldsymbol{\kappa}^{\mathbf{1}} \mathbf{-}\right.$ oxidaneyl)- $\Lambda^{3}$-sulfaneyl)methanimine (4b)

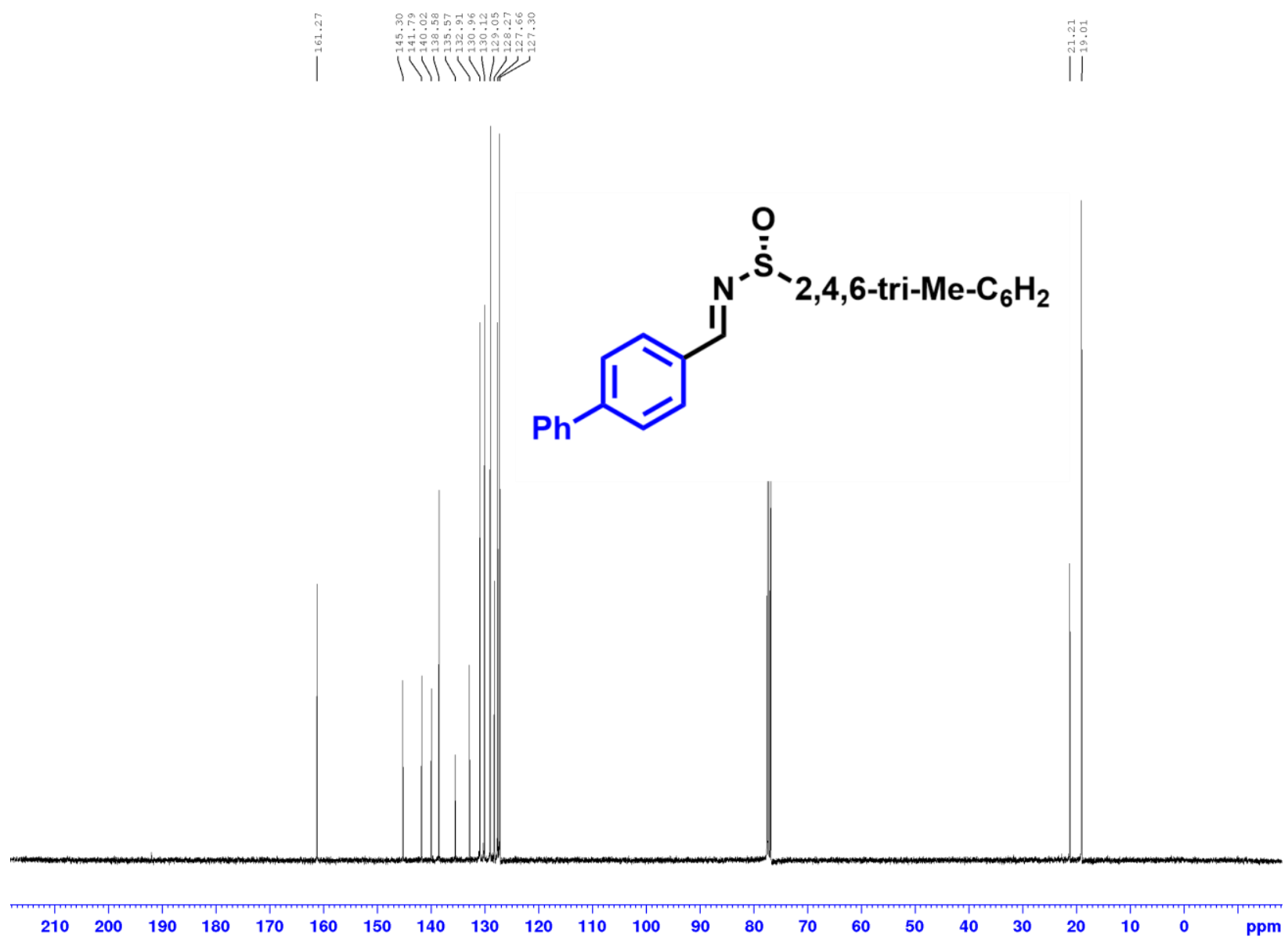


${ }^{1} \mathrm{H}$ NMR spectrum $\left(\left(\mathrm{CDCl}_{3}, 400 \mathrm{MHz}\right)\right.$ of $\mathbf{1}$-(4-chlorophenyl)- $\boldsymbol{N}$-(mesityl $\left(\boldsymbol{\Lambda}^{\mathbf{1}}\right.$-oxidaneyl)- $\boldsymbol{\Lambda}^{\mathbf{3}}$ sulfaneyl)methanimine (4d)

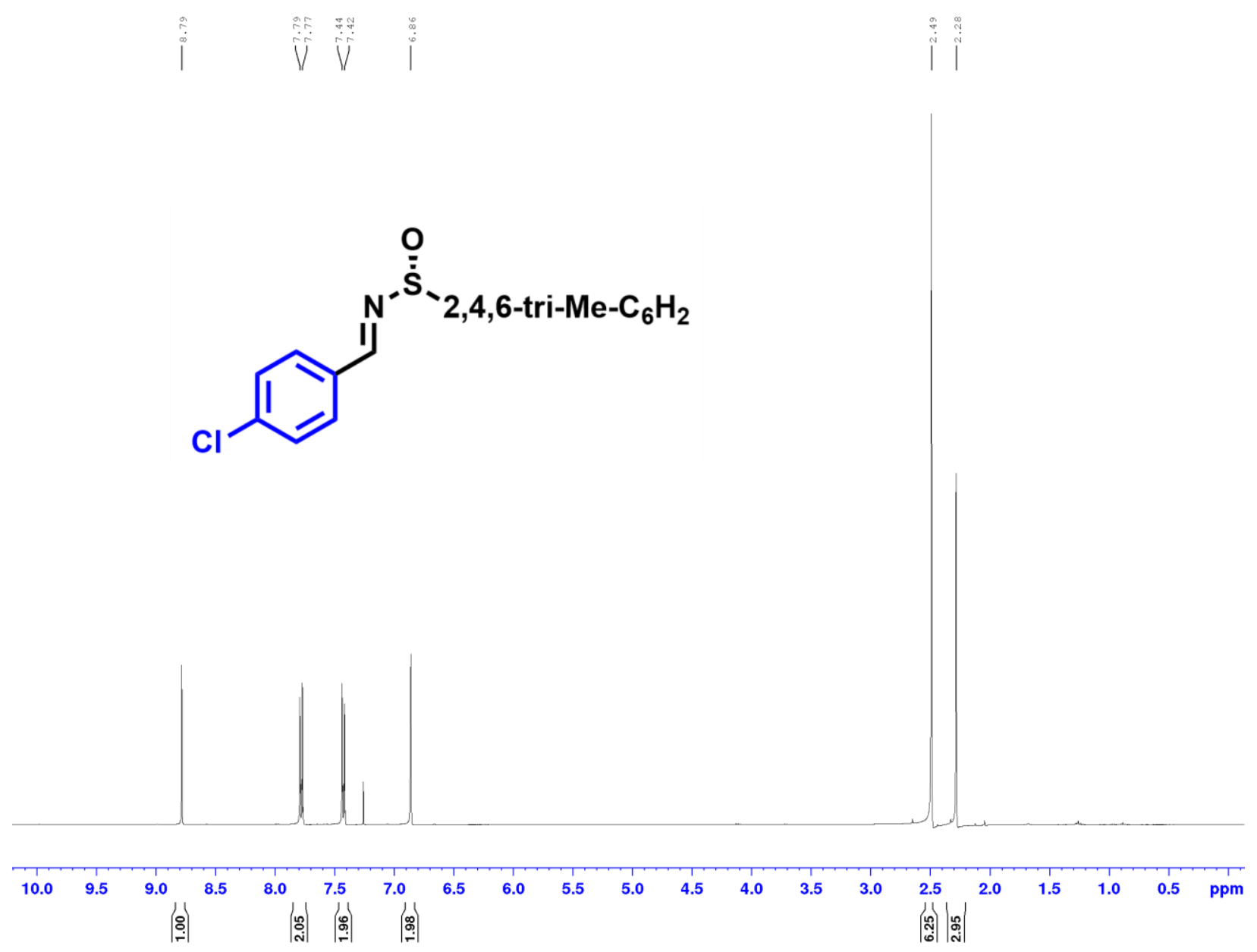


${ }^{13} \mathrm{C}\left\{{ }^{1} \mathrm{H}\right\}$ NMR spectrum $\left(\left(\mathrm{CDCl}_{3}, 100 \mathrm{MHz}\right)\right.$ of 1-(4-chlorophenyl)-N-(mesityl( $\boldsymbol{\Lambda}^{\mathbf{1}}$-oxidaneyl)$\boldsymbol{i}^{\mathbf{3}}$-sulfaneyl)methanimine $(\mathbf{4 d})$

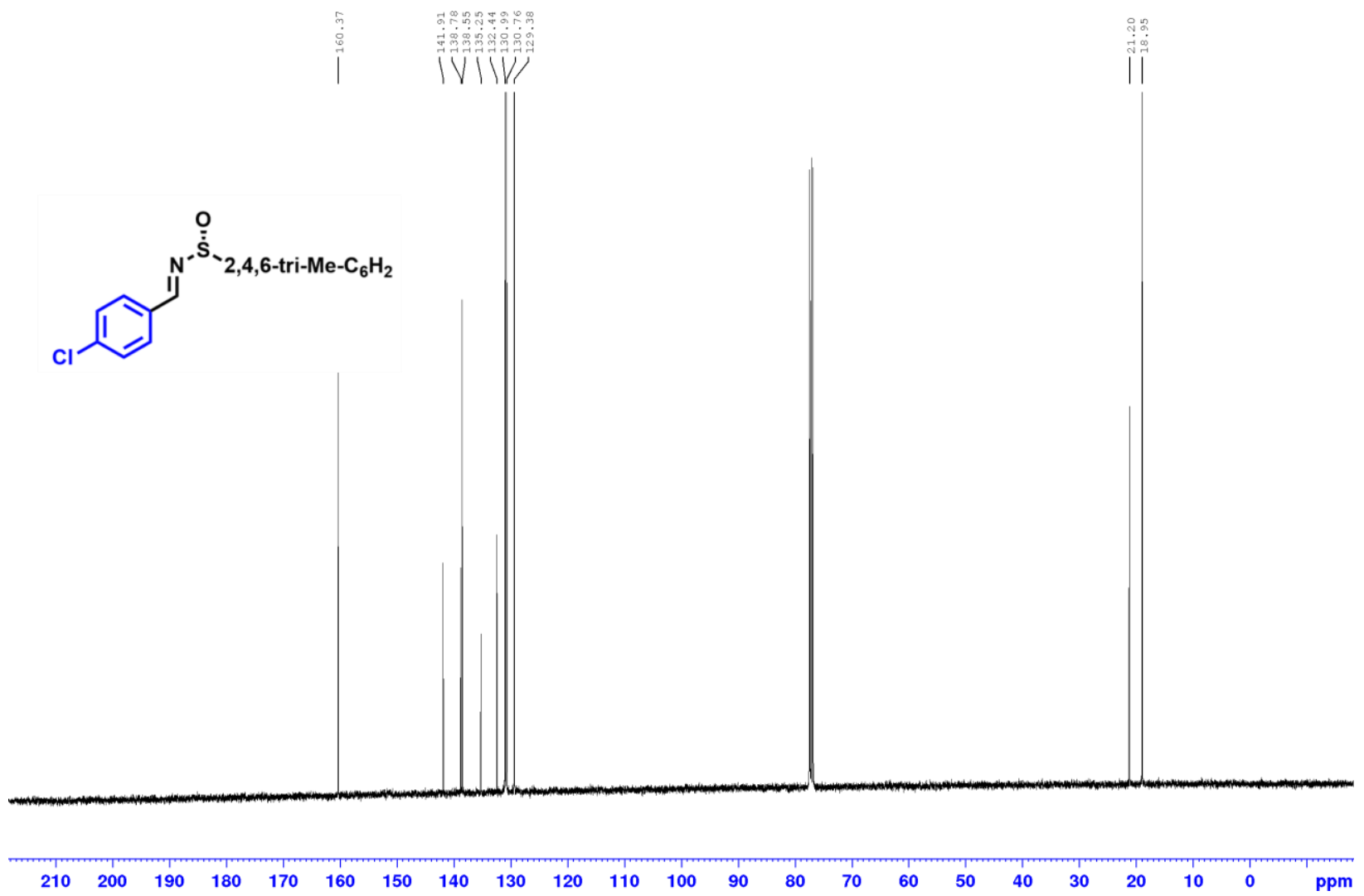


${ }^{1} \mathrm{H}$ NMR spectrum $\left(\left(\mathrm{CDCl}_{3}, 400 \mathrm{MHz}\right)\right.$ of (1-(2,6-dichloropyridin-3-yl)- $\boldsymbol{N}$-(mesityl $\left(\boldsymbol{\kappa}^{\mathbf{1}}\right.$ oxidaneyl)- $\Lambda^{3}$-sulfaneyl)methanimine $(4 \mathrm{~m})$

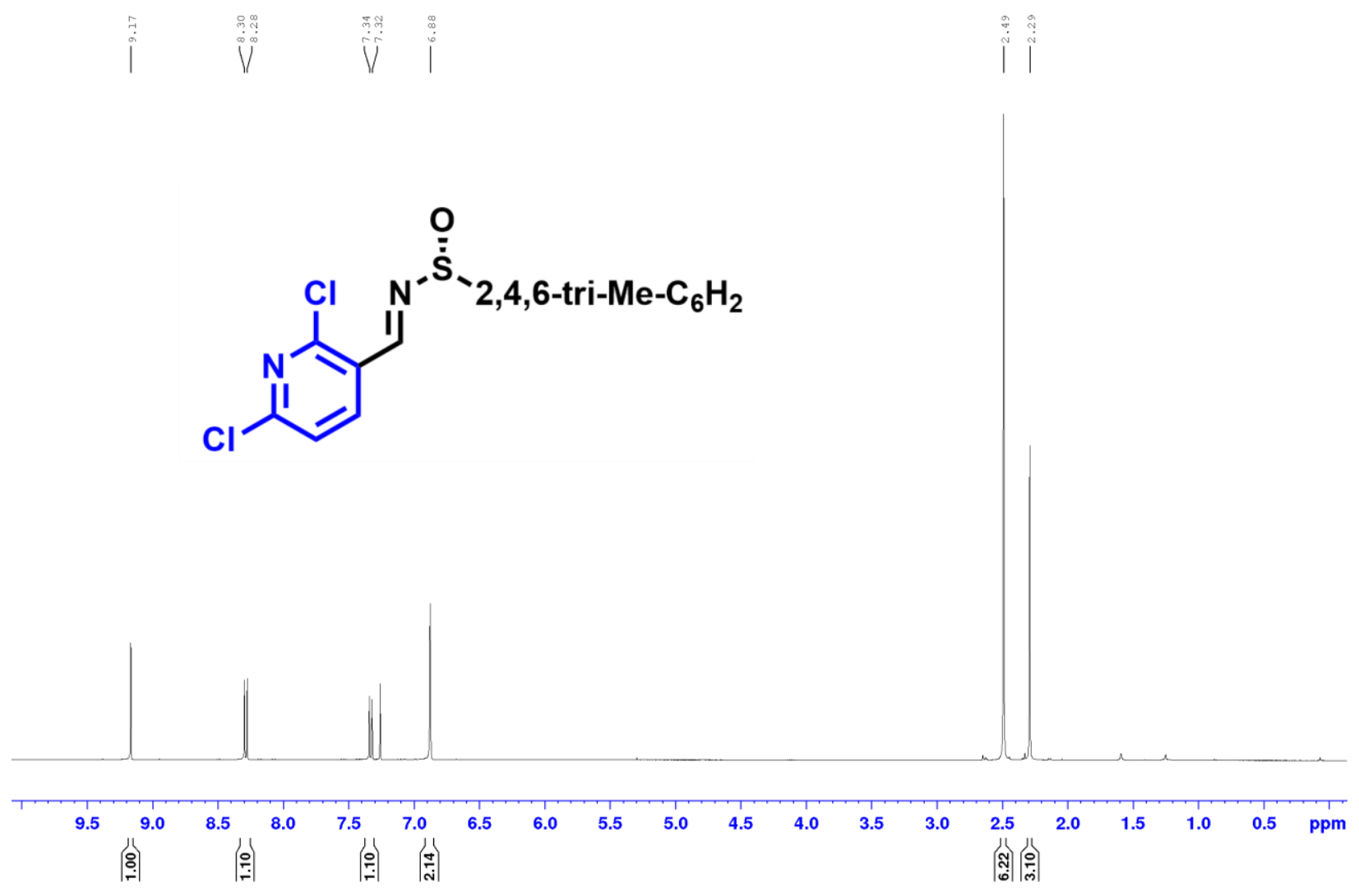


${ }^{13} \mathrm{C}\left\{{ }^{1} \mathrm{H}\right\}$ NMR spectrum $\left(\left(\mathrm{CDCl}_{3}, 100 \mathrm{MHz}\right)\right.$ of (1-(2,6-dichloropyridin-3-yl)- $\boldsymbol{N}$-(mesityl $\left(\boldsymbol{\Lambda}^{\mathbf{1}}\right.$ oxidaneyl)- $\Lambda^{3}$-sulfaneyl)methanimine $(4 \mathrm{~m})$

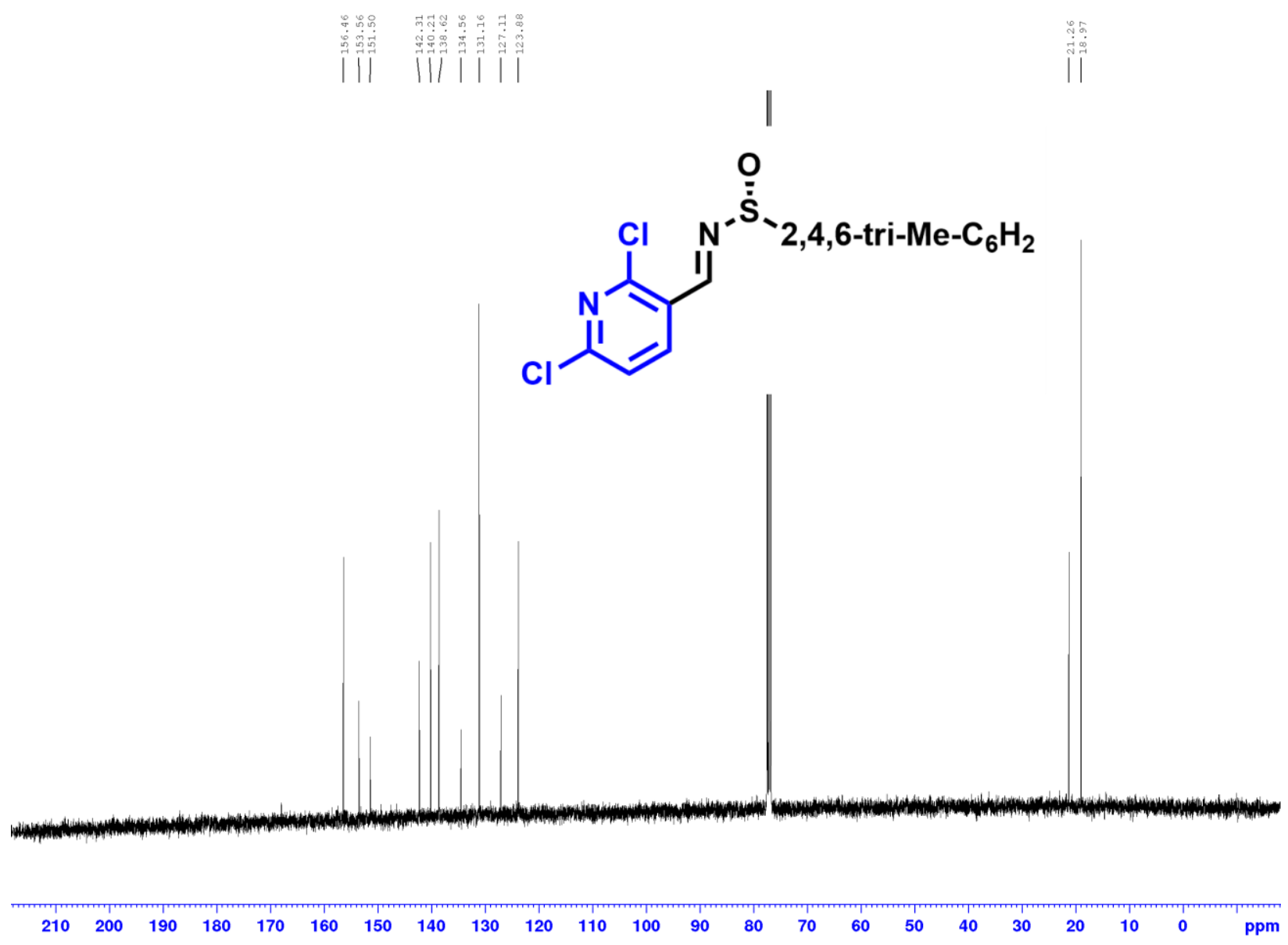


${ }^{1} \mathrm{H}$ NMR spectrum $\left(\left(\mathrm{CDCl}_{3}, 400 \mathrm{MHz}\right)\right.$ of $\boldsymbol{N}$-(mesityl $\left(\boldsymbol{\kappa}^{\mathbf{1}}\right.$-oxidaneyl)- $\boldsymbol{\kappa}^{\mathbf{3}}$-sulfaneyl)-1-(6methoxypyridin-2-yl)methanimine (4I)

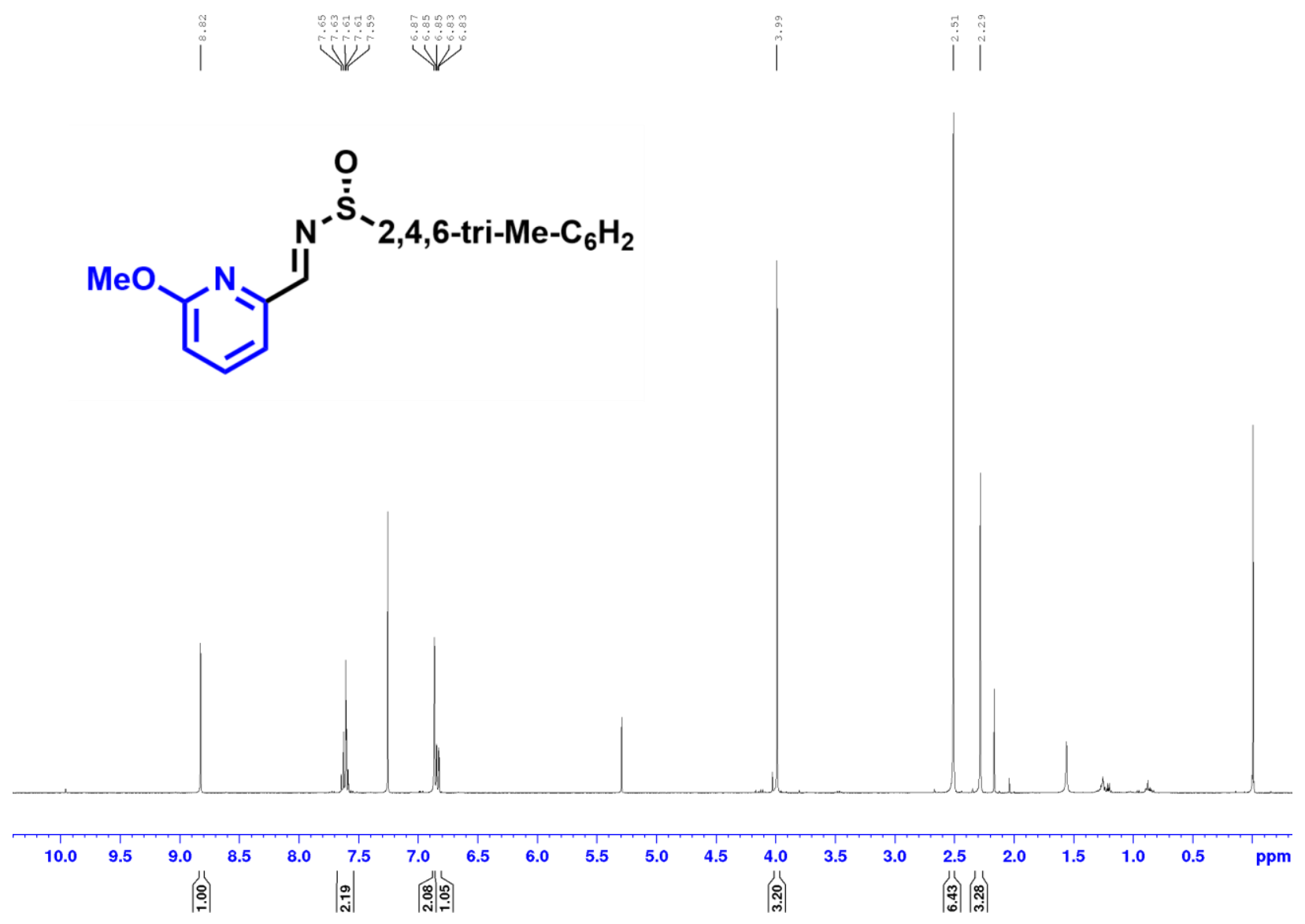


${ }^{13} \mathrm{C}\left\{{ }^{1} \mathrm{H}\right\}$ NMR spectrum $\left(\left(\mathrm{CDCl}_{3}, 100 \mathrm{MHz}\right)\right.$ of $\boldsymbol{N}$-(mesityl $\left(\boldsymbol{\kappa}^{\mathbf{1}}\right.$-oxidaneyl $)$ - $\boldsymbol{\Lambda}^{\mathbf{3}}$-sulfaneyl $)-\mathbf{1}-(\mathbf{6}-$ methoxypyridin-2-yl)methanimine (41)
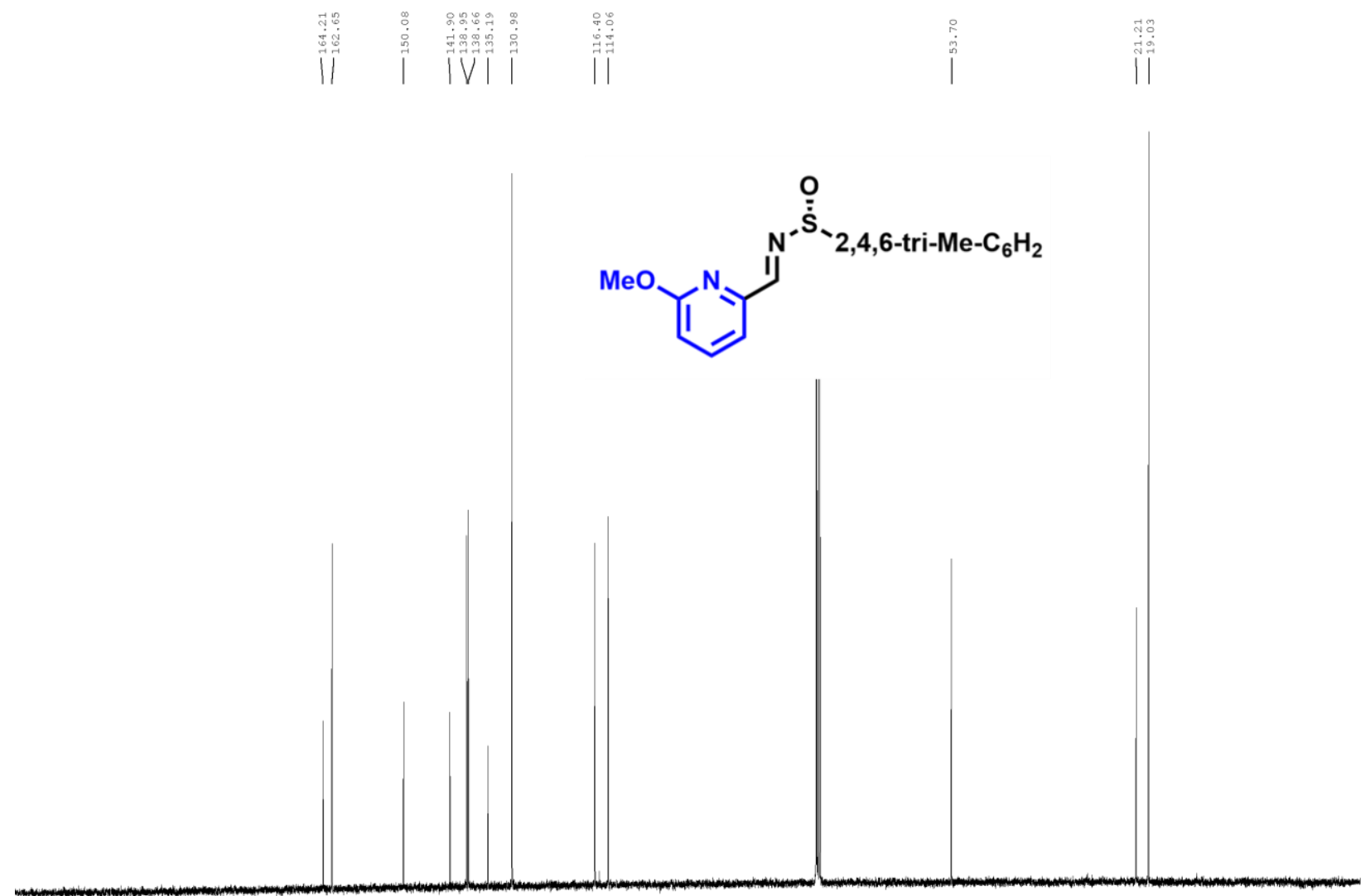

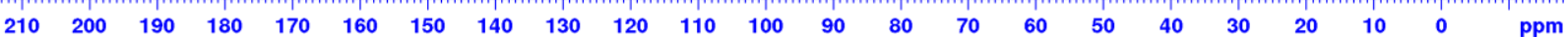


${ }^{1} \mathrm{H}$ NMR spectrum $\left(\left(\mathrm{CDCl}_{3}, 400 \mathrm{MHz}\right)\right.$ of $\mathbf{1 - ( 3 , 5 - b i s ( t r i f l u o r o m e t h y l ) p h e n y l ) - ~} \boldsymbol{N}$-(mesityl $\left(\boldsymbol{\kappa}^{\mathbf{1}}\right.$ oxidaneyl)- $\boldsymbol{\kappa}^{3}$-sulfaneyl)methanimine (4e)
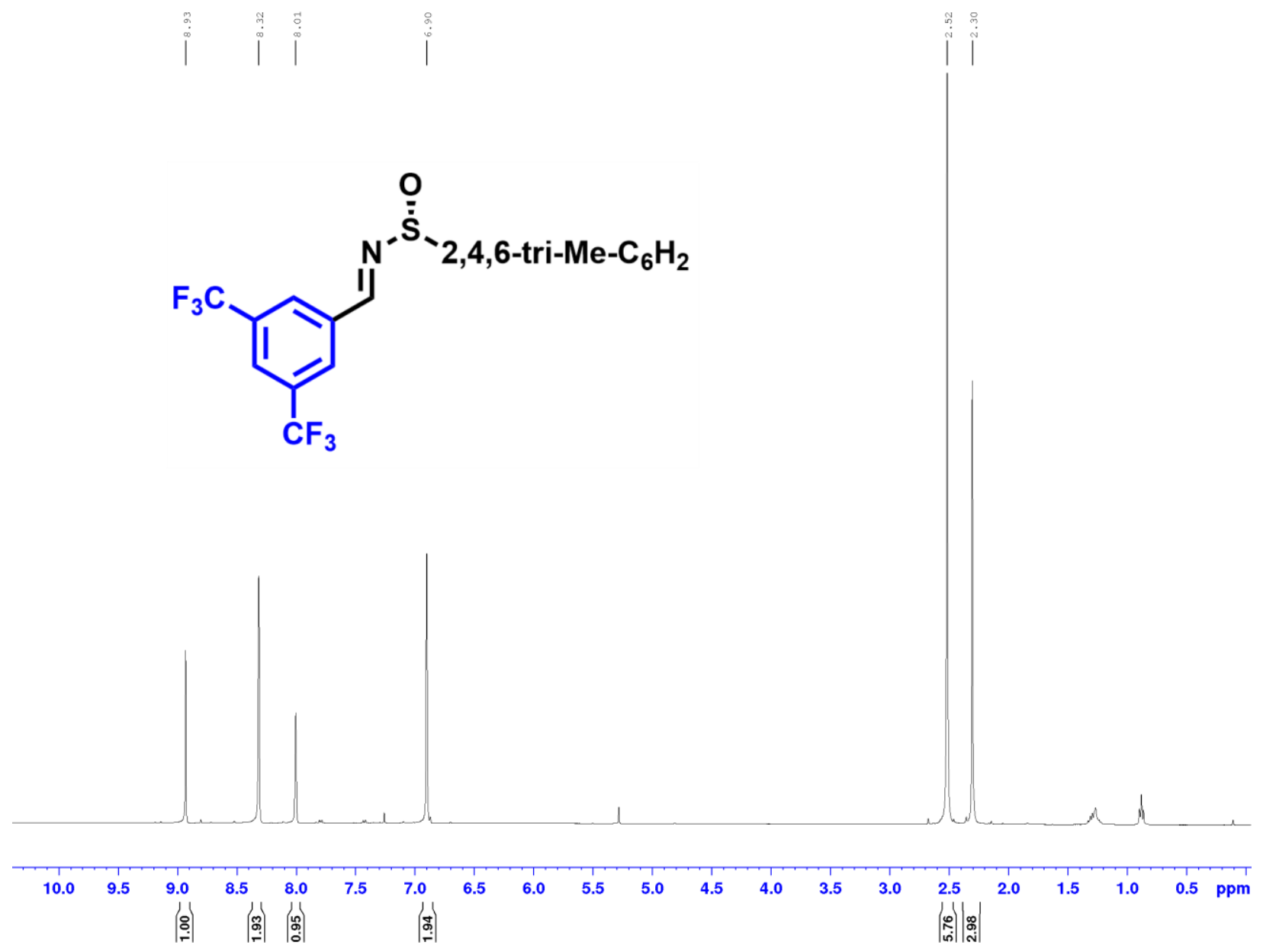
${ }^{13} \mathrm{C}\left\{{ }^{1} \mathrm{H}\right\}$ NMR spectrum $\left(\left(\mathrm{CDCl}_{3}, 100 \mathrm{MHz}\right)\right.$ of $\mathbf{1 - ( 3 , 5 - b i s ( t r i f l u o r o m e t h y l ) p h e n y l ) - ~} \mathrm{N}$ (mesityl $\left(\boldsymbol{\Lambda}^{1}\right.$-oxidaneyl)- $\boldsymbol{\Lambda}^{3}$-sulfaneyl $)$ methanimine $(4 \mathrm{e})$

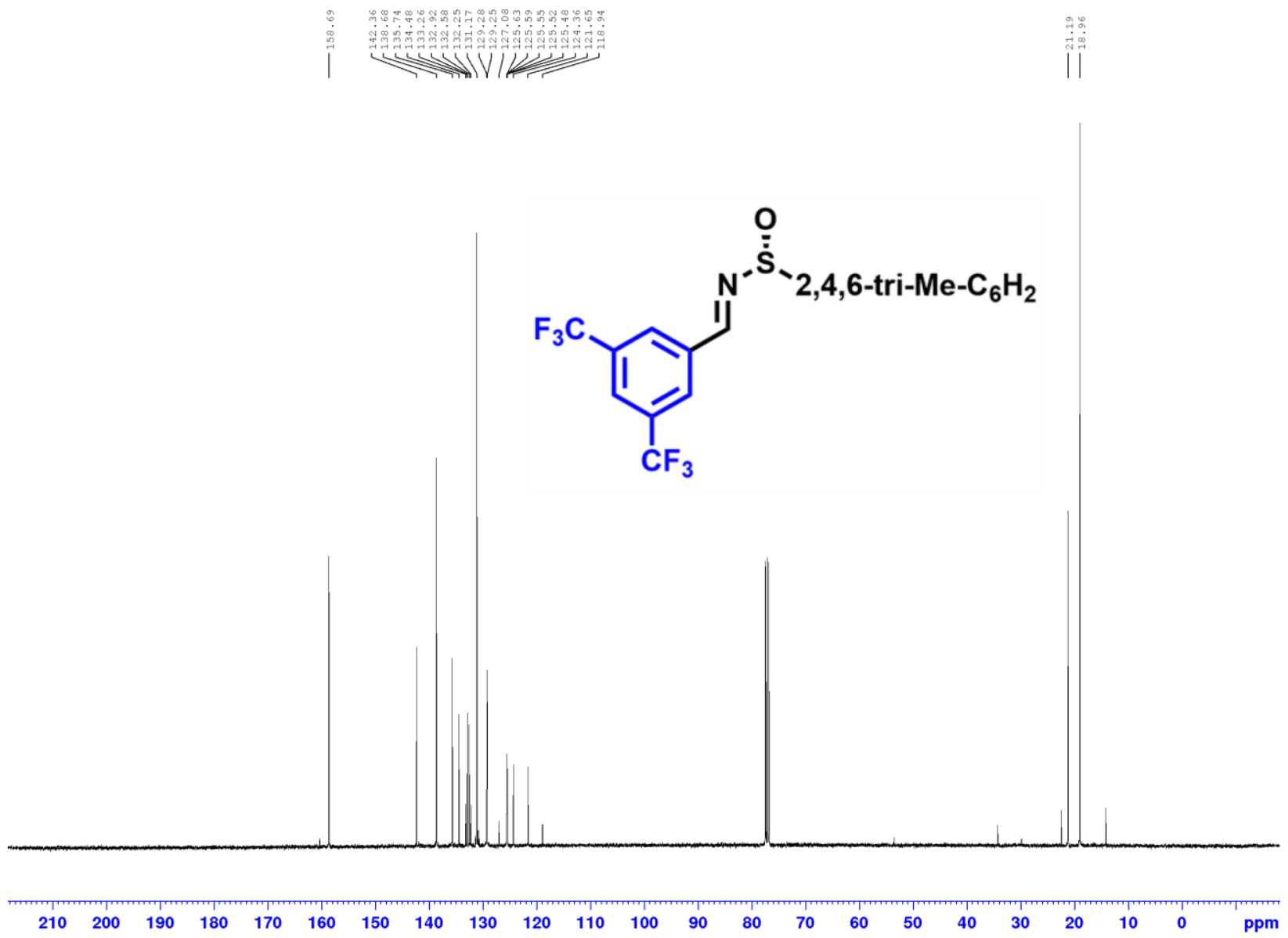


${ }^{1} \mathrm{H}$ NMR spectrum $\left(\mathrm{CDCl}_{3}, 400 \mathrm{MHz}\right)$ of 2-(((mesityl( $\lambda^{1}$-oxidaneyl)- $\lambda^{3}$ sulfaneyl)imino)methyl)phenethyl benzoate (4o)

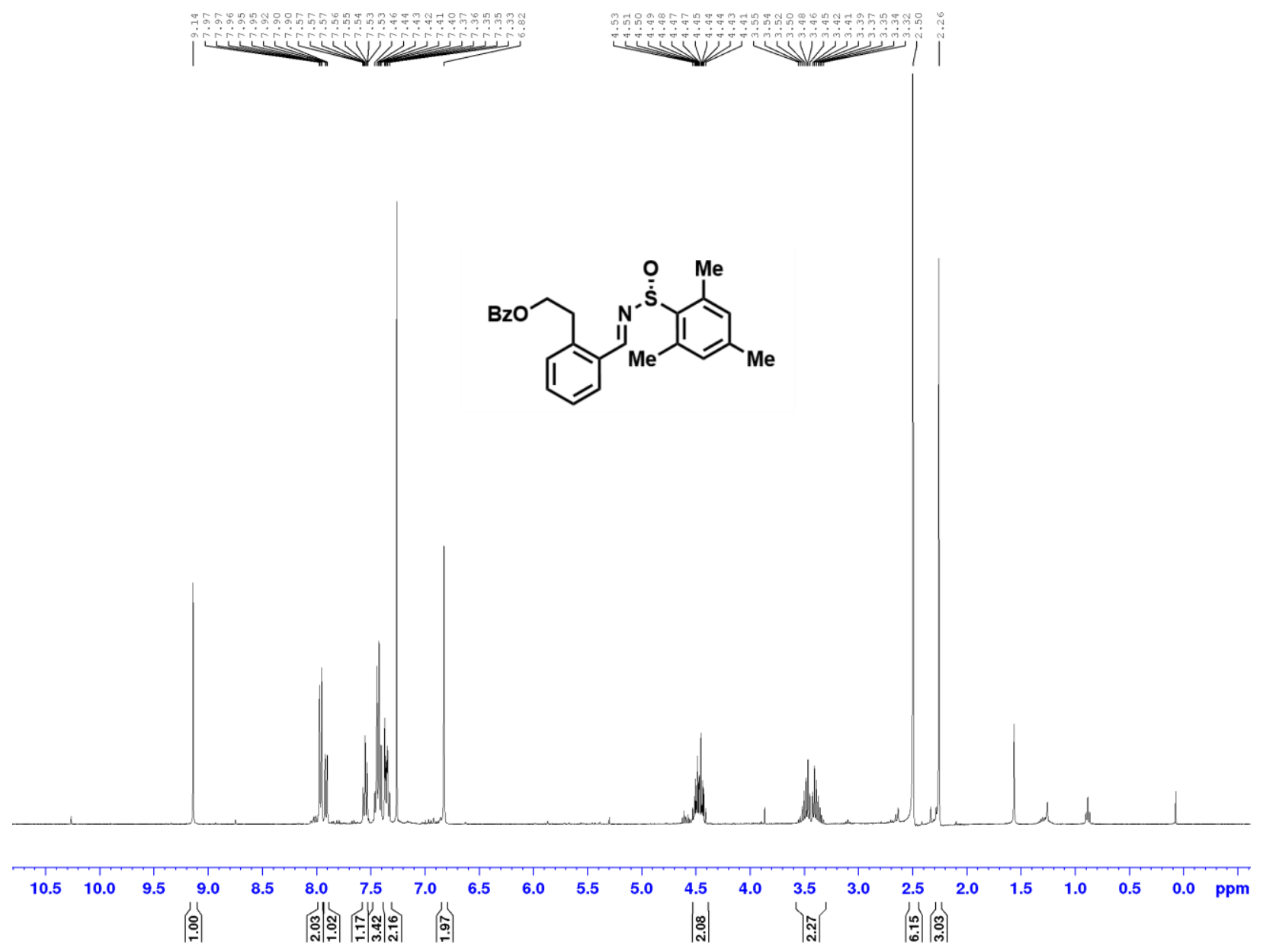


${ }^{13} \mathrm{C}\left\{{ }^{1} \mathrm{H}\right\}$ NMR spectrum $\left(\mathrm{CDCl}_{3}, 100 \mathrm{MHz}\right)$ of $\mathbf{2}$-(((mesityl( $\boldsymbol{\lambda}^{\mathbf{1}}$-oxidaneyl $)-\boldsymbol{\lambda}^{\mathbf{3}}$ sulfaneyl)imino)methyl)phenethyl benzoate (4o)

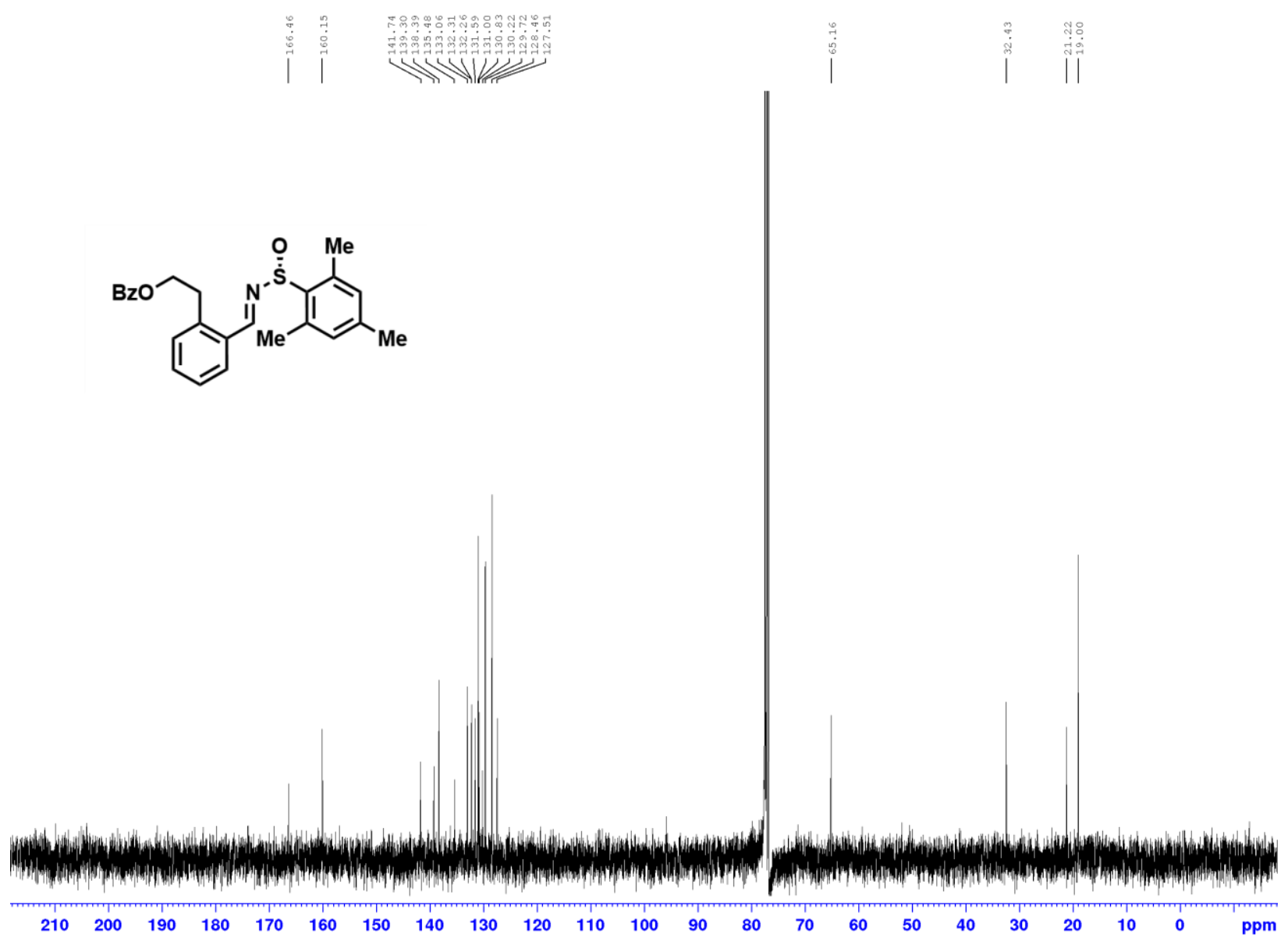


${ }^{1} \mathrm{H}$ NMR spectrum $\left(\mathrm{CDCl}_{3}, 400 \mathrm{MHz}\right)$ of $N$-(bicyclo[1.1.1]pentan-1-yl(phenyl)methyl)-2,4,6trimethylbenzenesulfinamide (9a)

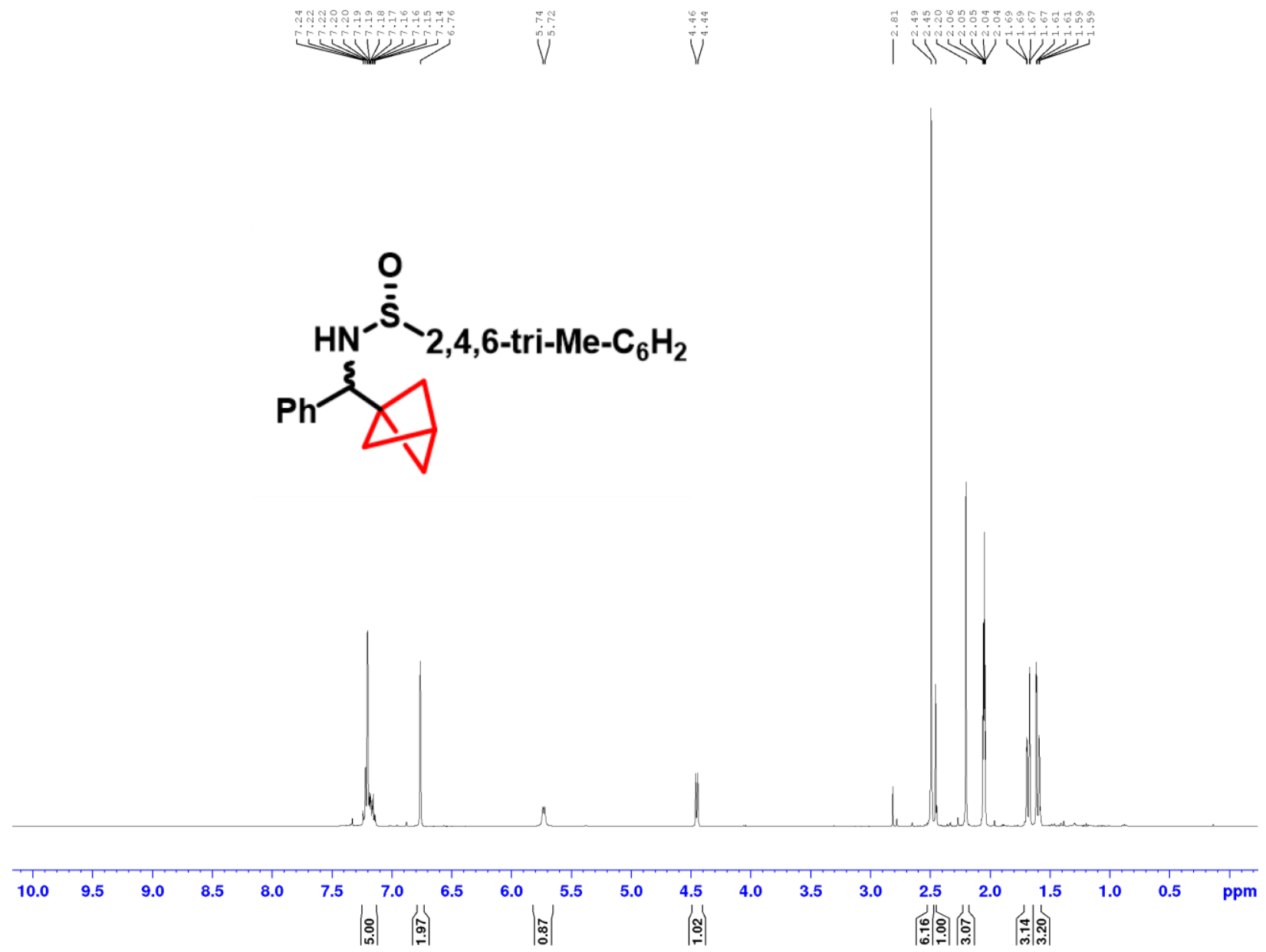


${ }^{13} \mathrm{C}\left\{{ }^{1} \mathrm{H}\right\}$ NMR spectrum $\left(\left(\mathrm{CD}_{3}\right)_{2} \mathrm{CO}, 100 \mathrm{MHz}\right)$ of $\boldsymbol{N}$-(bicyclo[1.1.1]pentan-1yl(phenyl)methyl)-2,4,6-trimethylbenzenesulfinamide (9a)

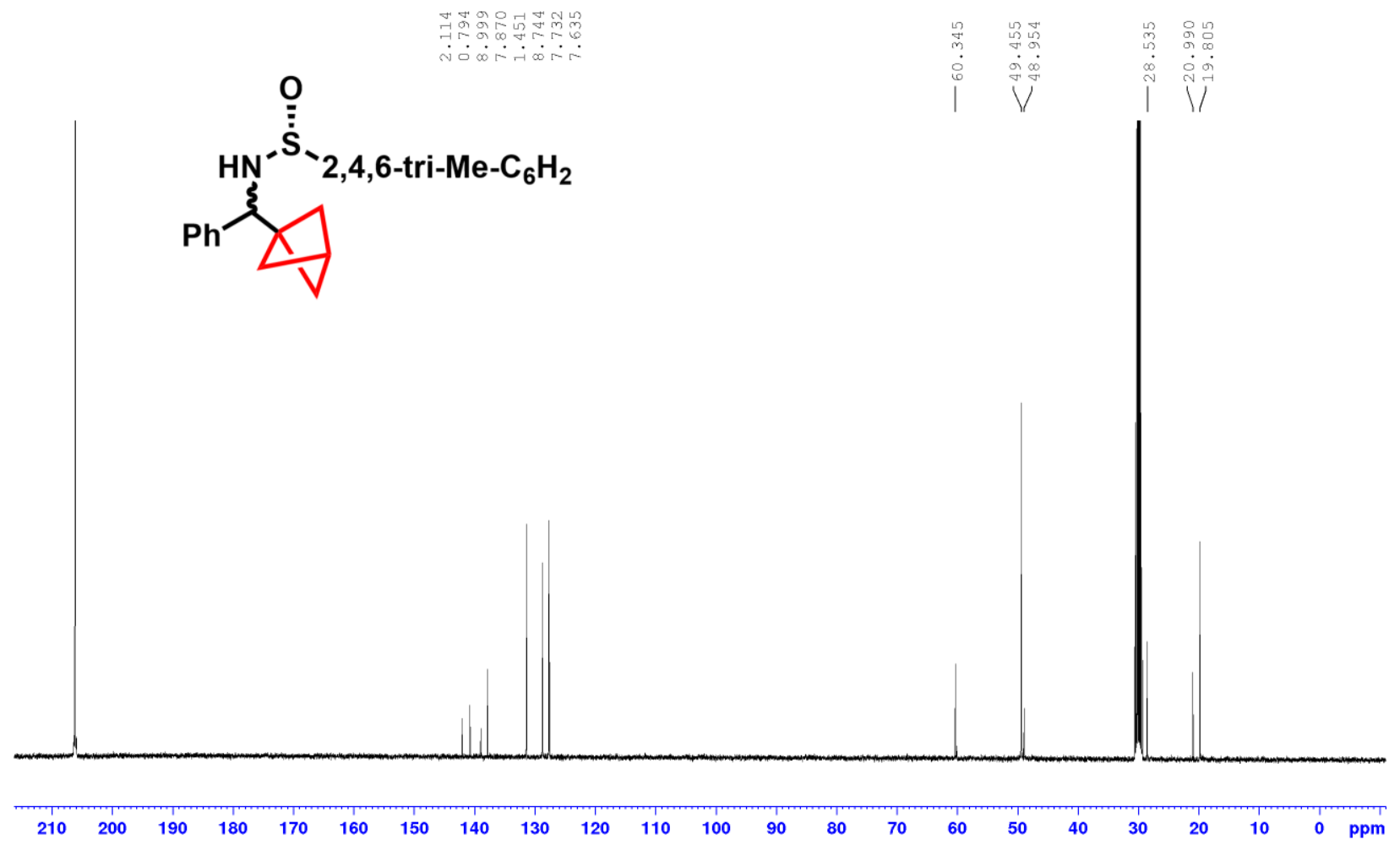


${ }^{1} \mathrm{H}$ NMR spectrum $\left(\mathrm{CDCl}_{3}, 400 \mathrm{MHz}\right)$ of $N$-([1,1'-biphenyl]-4-yl(bicyclo[1.1.1]pentan-1yl)methyl)-1-mesityl-1-( $\boldsymbol{\Lambda}^{1}$-oxidaneyl)- $\boldsymbol{\Lambda}^{3}$-sulfanamine $(9 \mathrm{~b})$

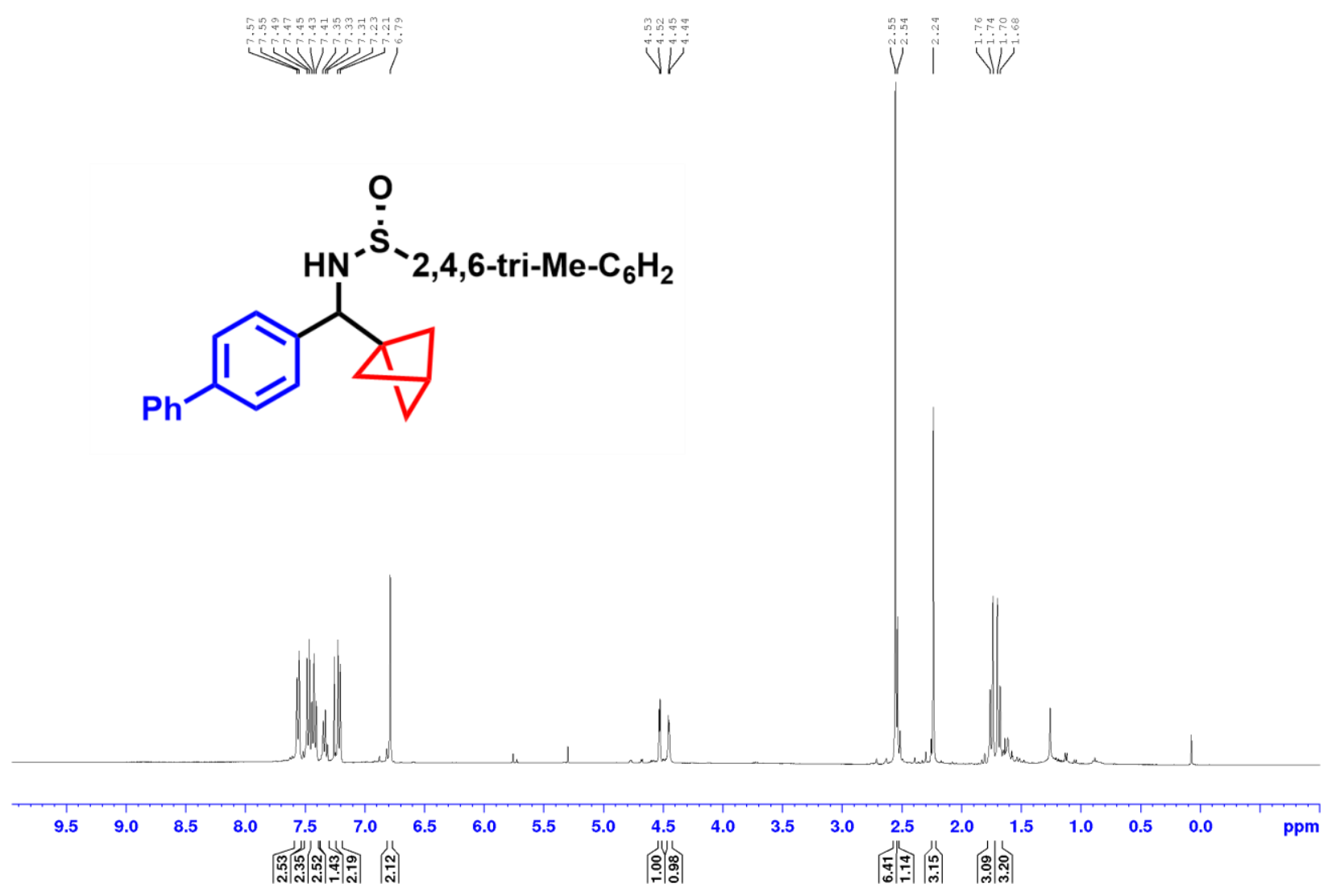


${ }^{13} \mathrm{C}\left\{{ }^{1} \mathrm{H}\right\}$ NMR spectrum $\left(\mathrm{CDCl}_{3}, 100 \mathrm{MHz}\right)$ of $N$-([1,1'-biphenyl]-4-yl(bicyclo[1.1.1]pentan-1yl)methyl)-1-mesityl-1-( $\kappa^{1}$-oxidaneyl)- $\kappa^{3}$-sulfanamine $(9 \mathrm{~b})$

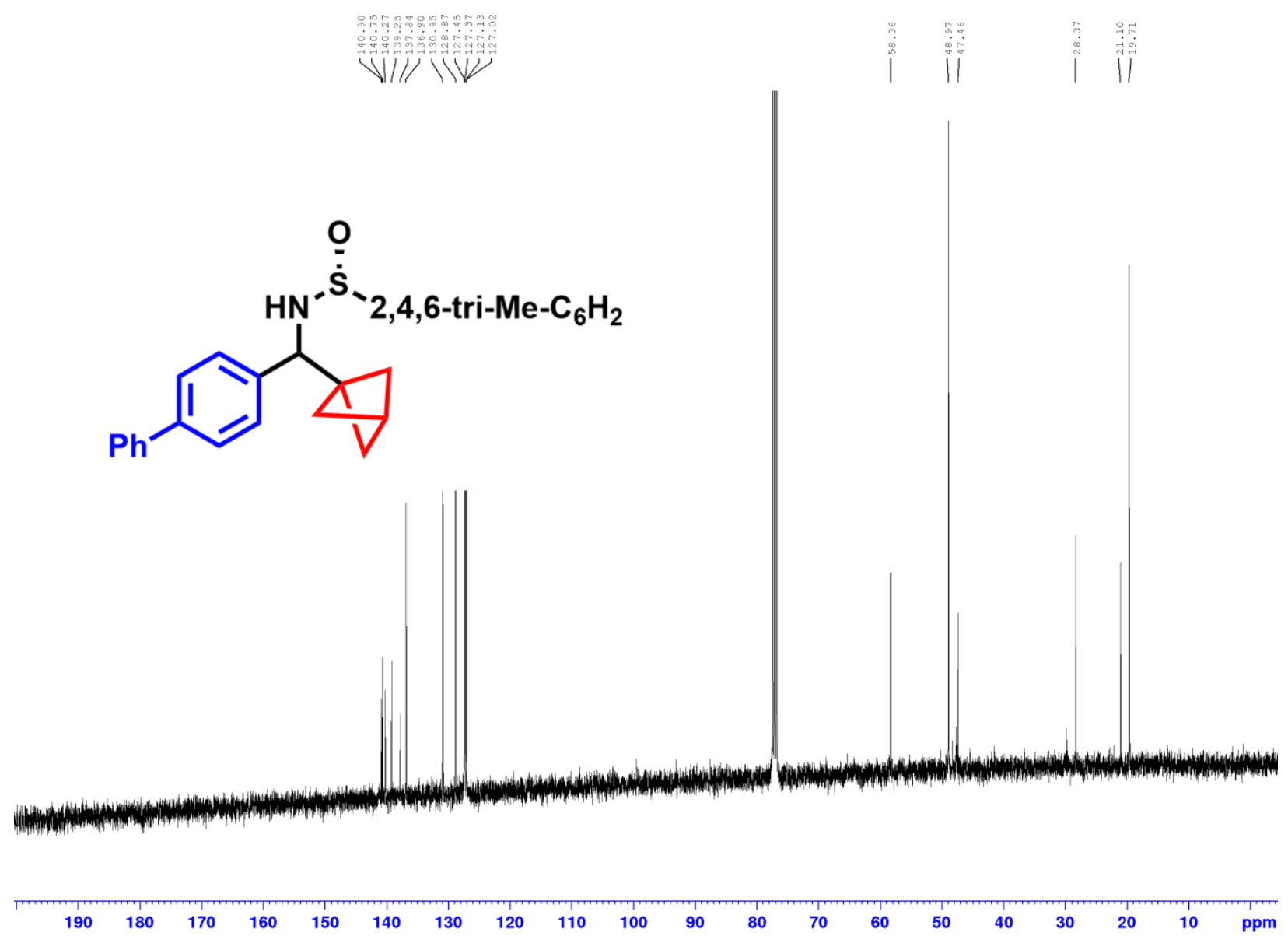


${ }^{1} \mathrm{H} \mathrm{NMR}$ spectrum $\left(\mathrm{CDCl}_{3}, 400 \mathrm{MHz}\right)$ of $\mathbf{N}$-(bicyclo[1.1.1]pentan-1-yl(3chlorophenyl)methyl)-1-mesityl-1-( $\Lambda^{1}$-oxidaneyl)- $\kappa^{3}$-sulfanamine $(9 \mathrm{c})$

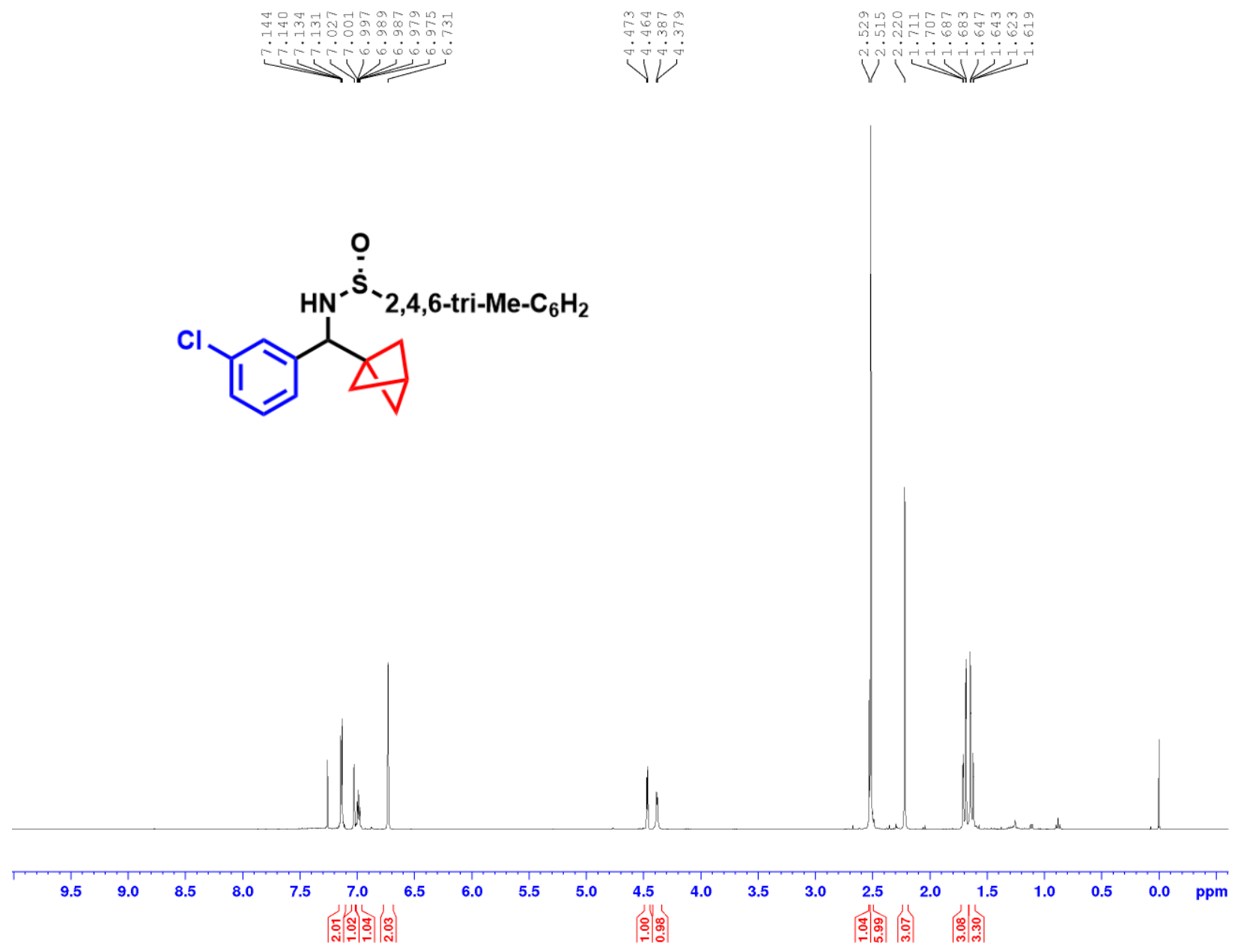


${ }^{13} \mathrm{C}\left\{{ }^{1} \mathrm{H}\right\}$ NMR spectrum $\left(\mathrm{CDCl}_{3}, 100 \mathrm{MHz}\right)$ of $N$-(bicyclo[1.1.1]pentan-1-yl(3chlorophenyl)methyl)-1-mesityl-1- $\left(\kappa^{1}\right.$-oxidaneyl)- $\kappa^{3}$-sulfanamine $(9 \mathrm{c})$

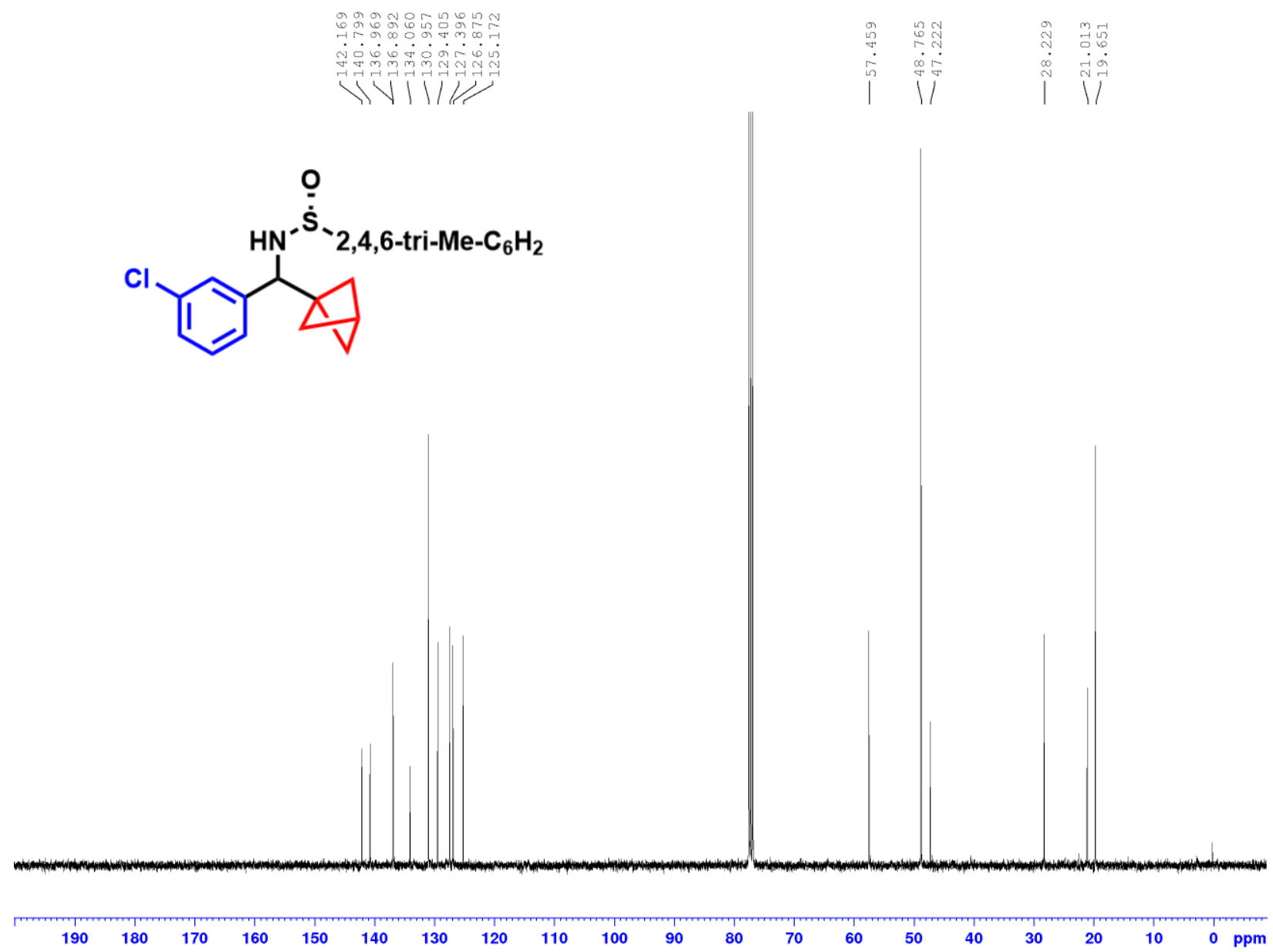


${ }^{1} \mathrm{H}$ NMR spectrum $\left(\mathrm{CDCl}_{3}, 400 \mathrm{MHz}\right)$ of $\boldsymbol{N}$-(bicyclo[1.1.1]pentan-1-yl(4chlorophenyl)methyl)-1-mesityl-1-( $\kappa^{1}$-oxidaneyl)- $\kappa^{3}$-sulfanamine $(9 d)$

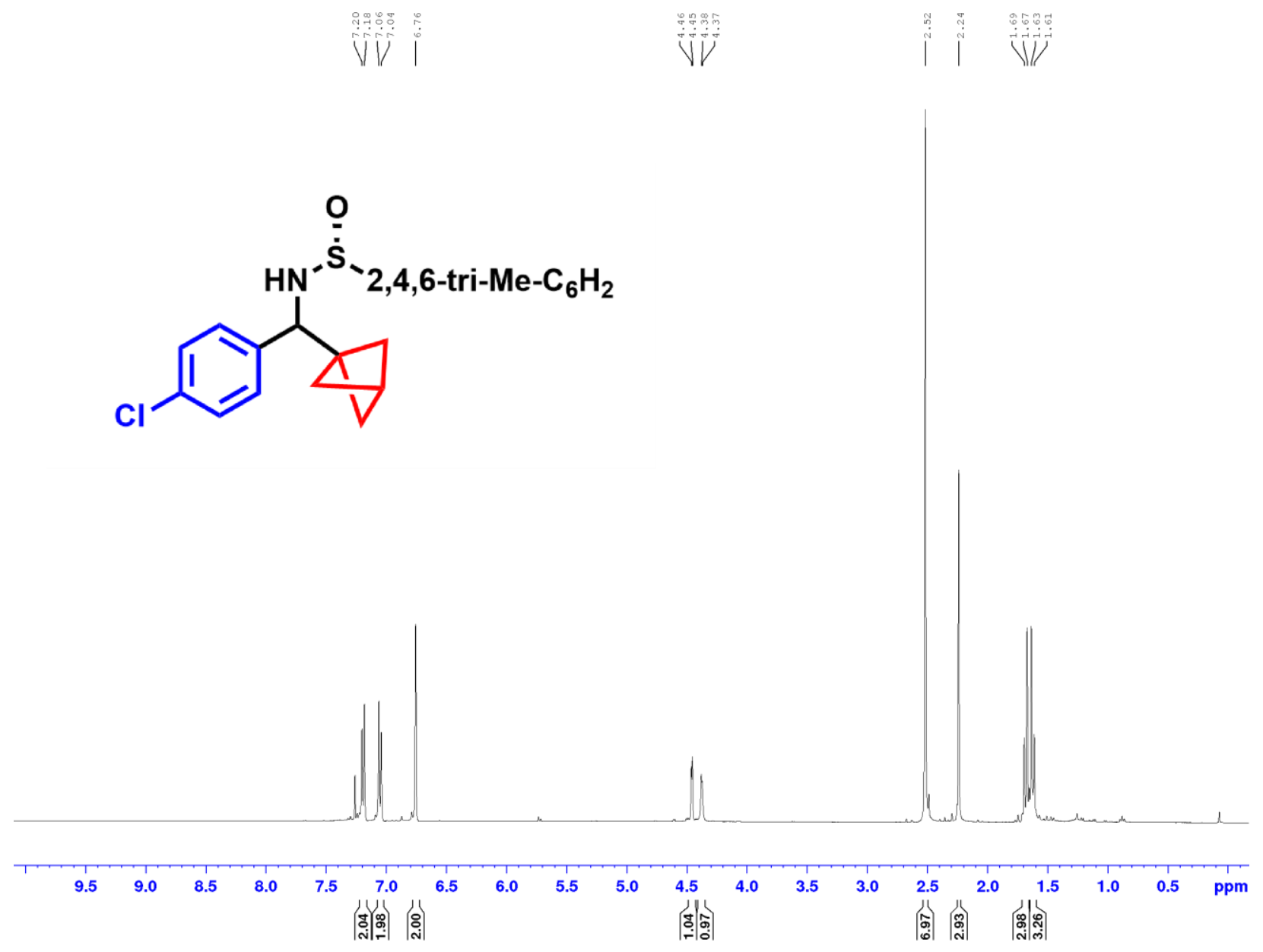


${ }^{13} \mathrm{C}\left\{{ }^{1} \mathrm{H}\right\}$ NMR spectrum $\left(\mathrm{CDCl}_{3}, 100 \mathrm{MHz}\right)$ of $N$-(bicyclo[1.1.1]pentan-1-yl(4chlorophenyl)methyl)-1-mesityl-1-( $\hat{\Lambda}^{1}$-oxidaneyl)- $\kappa^{3}$-sulfanamine $(9 \mathrm{~d})$
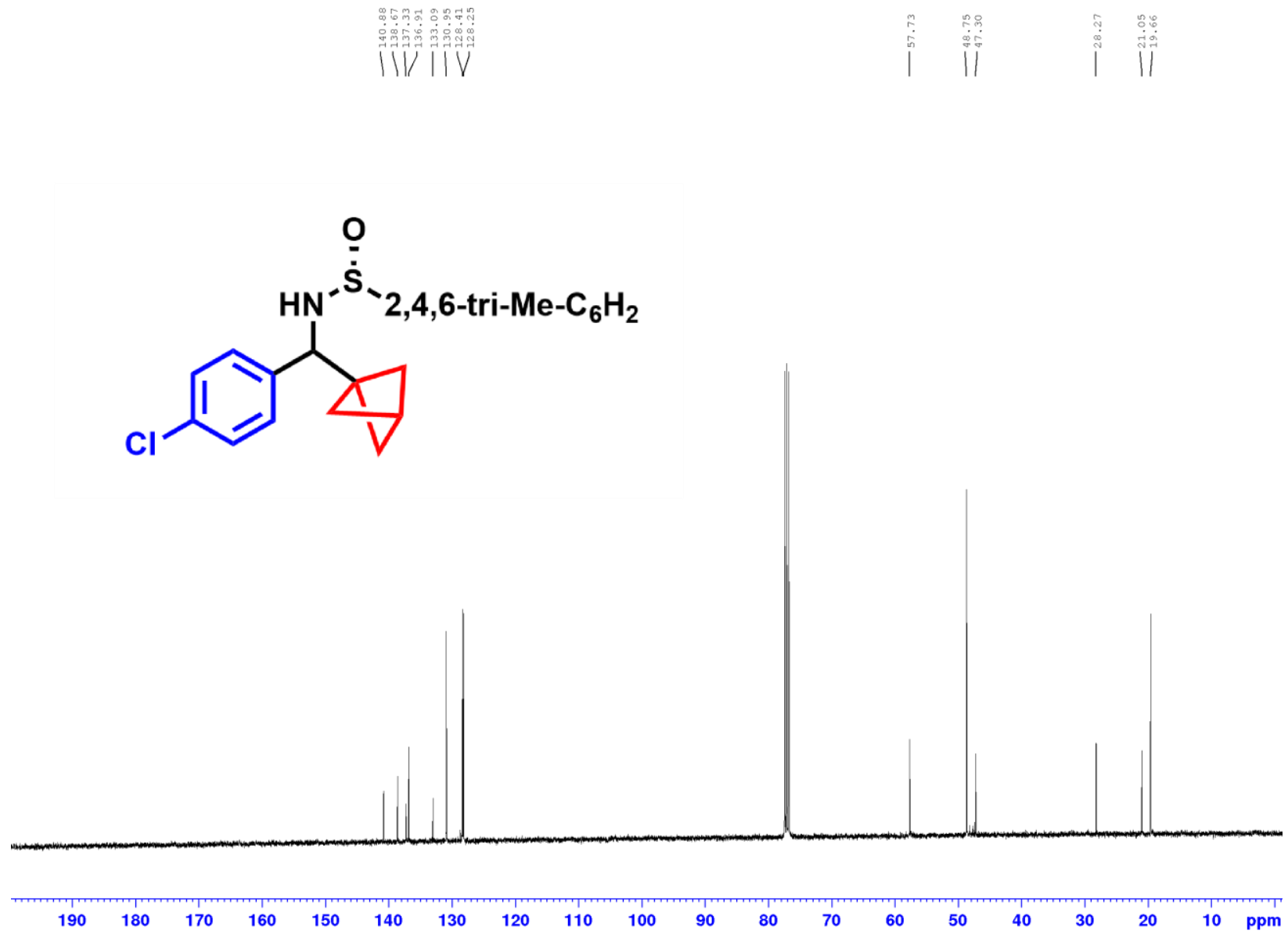
${ }^{1} \mathrm{H}$ NMR spectrum $\left(\mathrm{CDCl}_{3}, 400 \mathrm{MHz}\right)$ of $N$-(bicyclo[1.1.1]pentan-1-yl(3,5bis(trifluoromethyl)phenyl)methyl)-1-mesityl-1-( $\boldsymbol{\Lambda}^{1}$-oxidaneyl $)-\kappa^{3}$-sulfanamine $(9 \mathrm{e})$

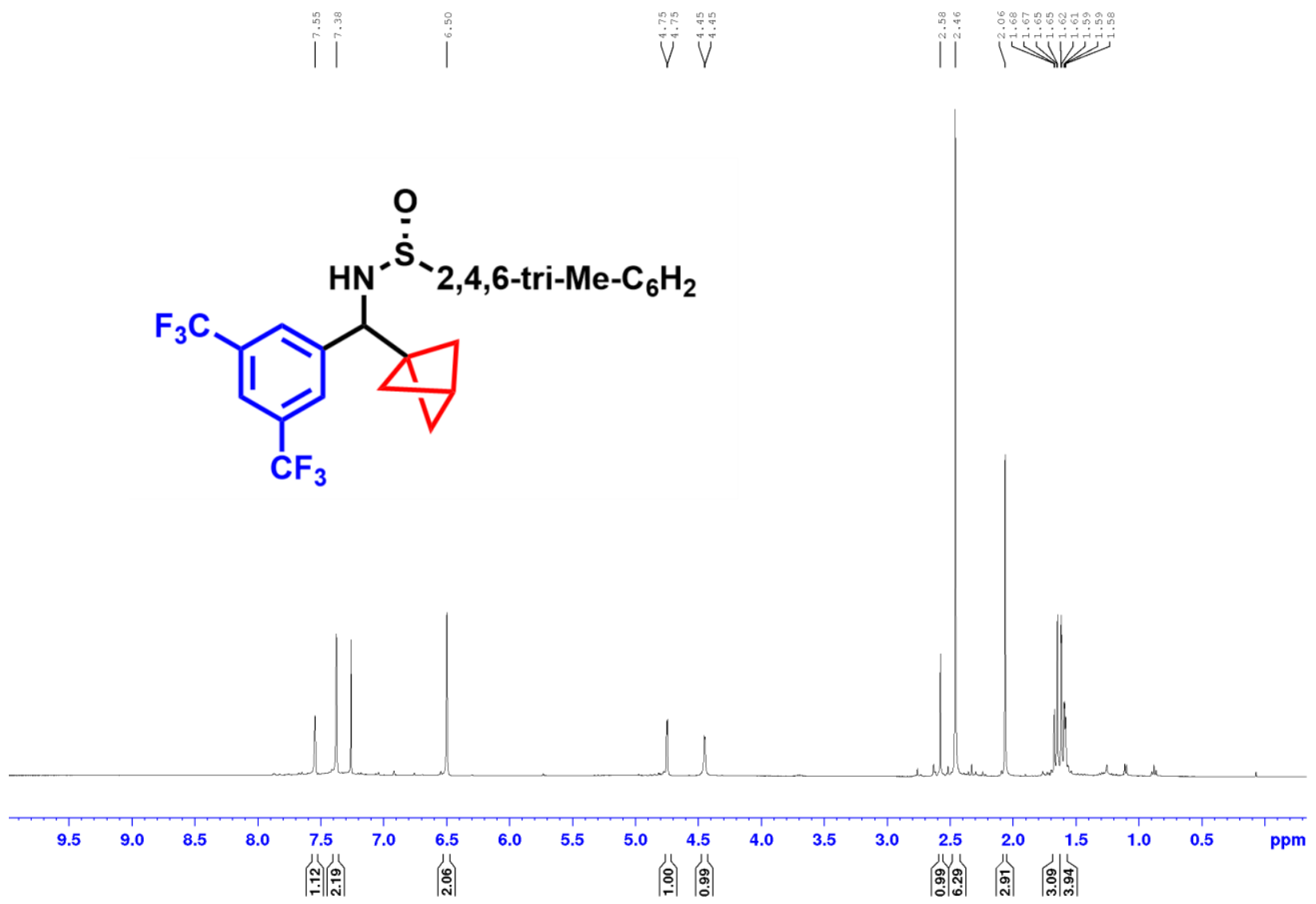


${ }^{13} \mathrm{C}\left\{{ }^{1} \mathrm{H}\right\}$ NMR spectrum $\left(\left(\mathrm{CD}_{3}\right)_{2} \mathrm{CO}, 100 \mathrm{MHz}\right)$ of $\boldsymbol{N}$-(bicyclo[1.1.1]pentan-1-yl(3,5bis(trifluoromethyl)phenyl)methyl)-1-mesityl-1-( $\boldsymbol{\Lambda}^{1}$-oxidaneyl $)-\kappa^{3}$-sulfanamine $(9 \mathrm{e})$

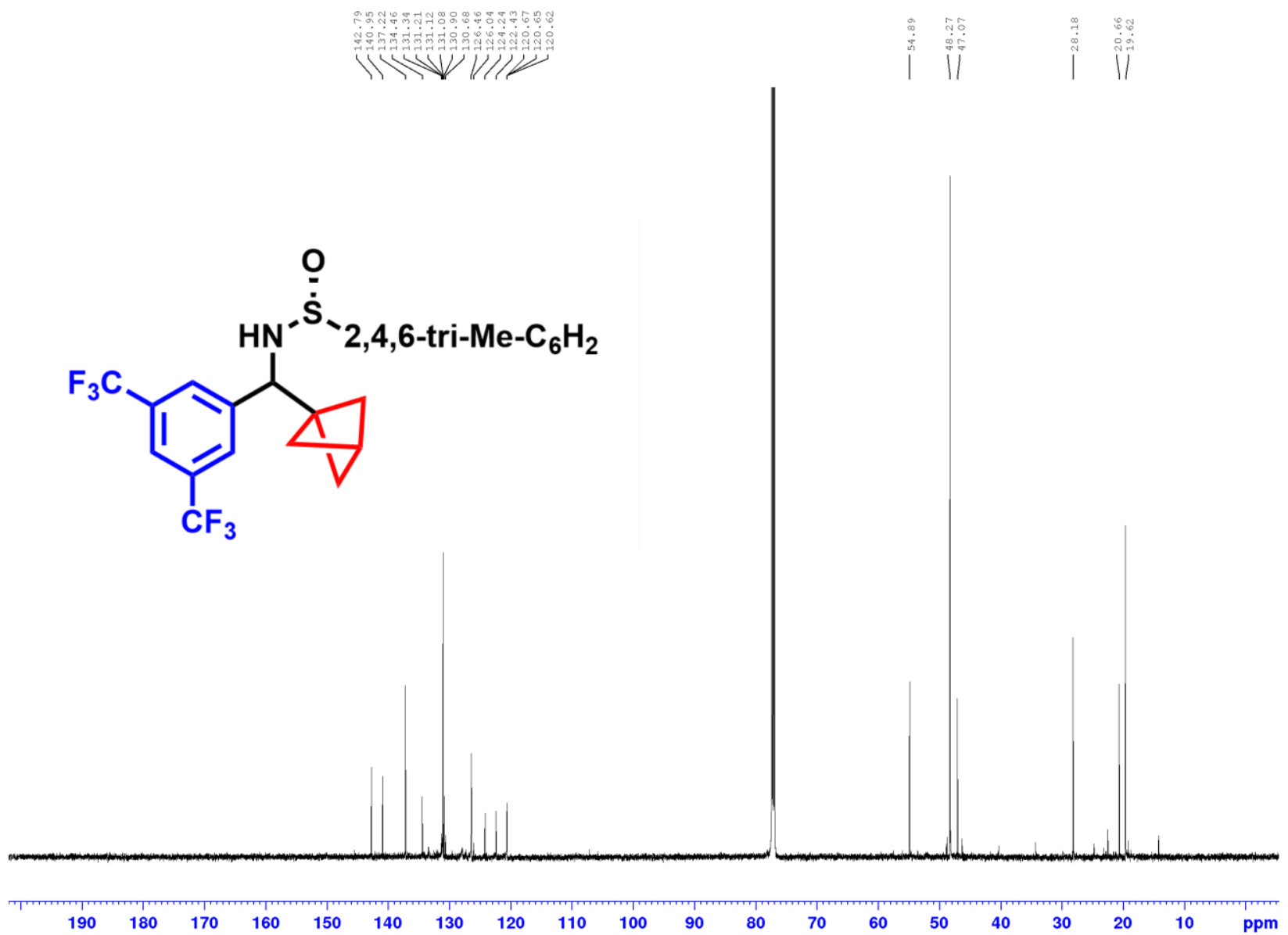


${ }^{1} \mathrm{H}$ NMR spectrum $\left(\mathrm{CDCl}_{3}, 400 \mathrm{MHz}\right)$ of $\boldsymbol{N}$-(bicyclo[1.1.1]pentan-1-yl(2bromophenyl)methyl)-1-mesityl-1-( $\boldsymbol{\Lambda}^{1}$-oxidaneyl)- $\boldsymbol{\Lambda}^{3}$-sulfanamine $(9 f)$
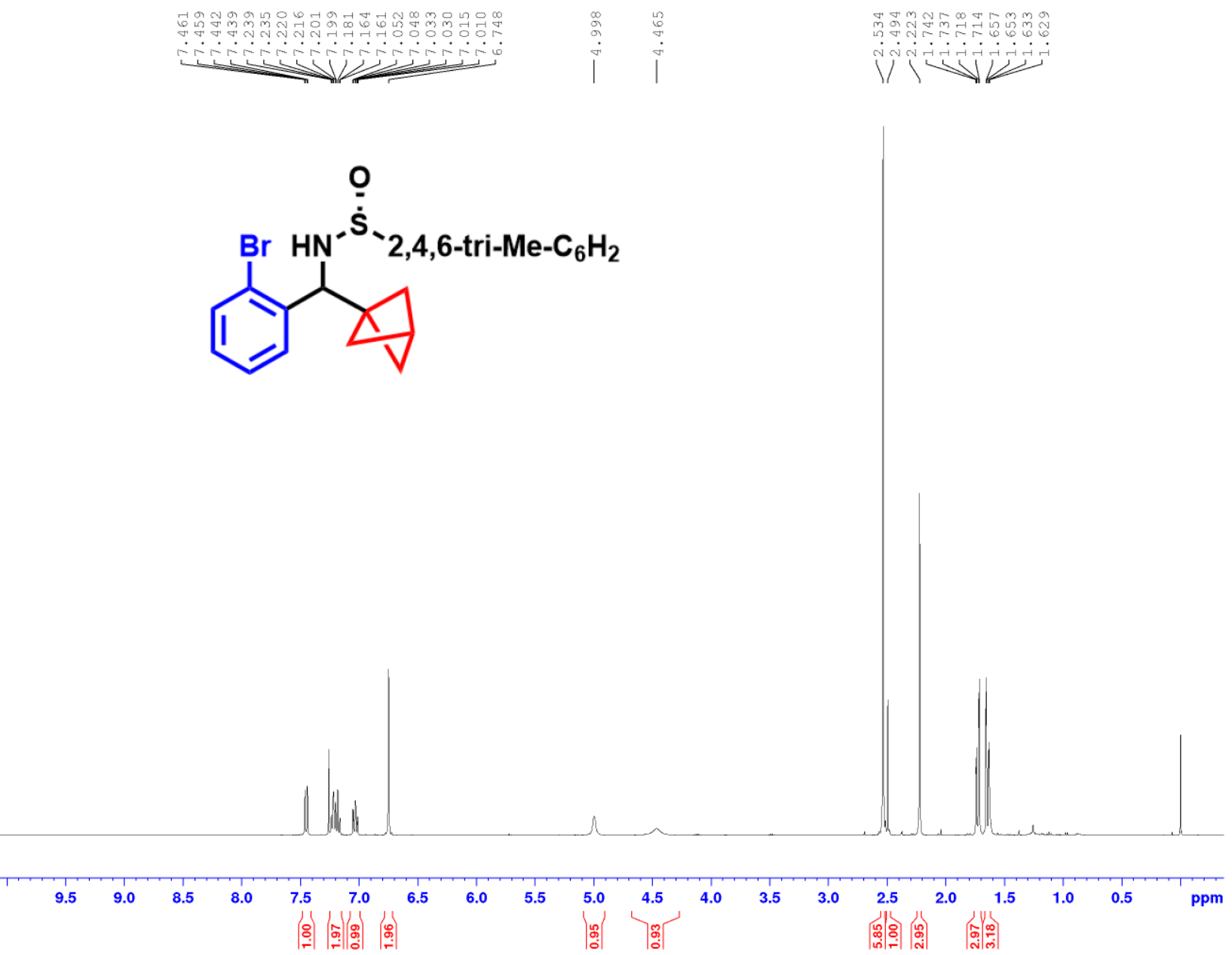
${ }^{13} \mathrm{C}\left\{{ }^{1} \mathrm{H}\right\}$ NMR spectrum $\left(\mathrm{CDCl}_{3}, 100 \mathrm{MHz}\right)$ of $N$-(bicyclo[1.1.1]pentan-1-yl(2bromophenyl)methyl)-1-mesityl-1-( $\boldsymbol{\Lambda}^{\mathbf{1}}$-oxidaneyl)- $\boldsymbol{\Lambda}^{\mathbf{3}}$-sulfanamine (9f)

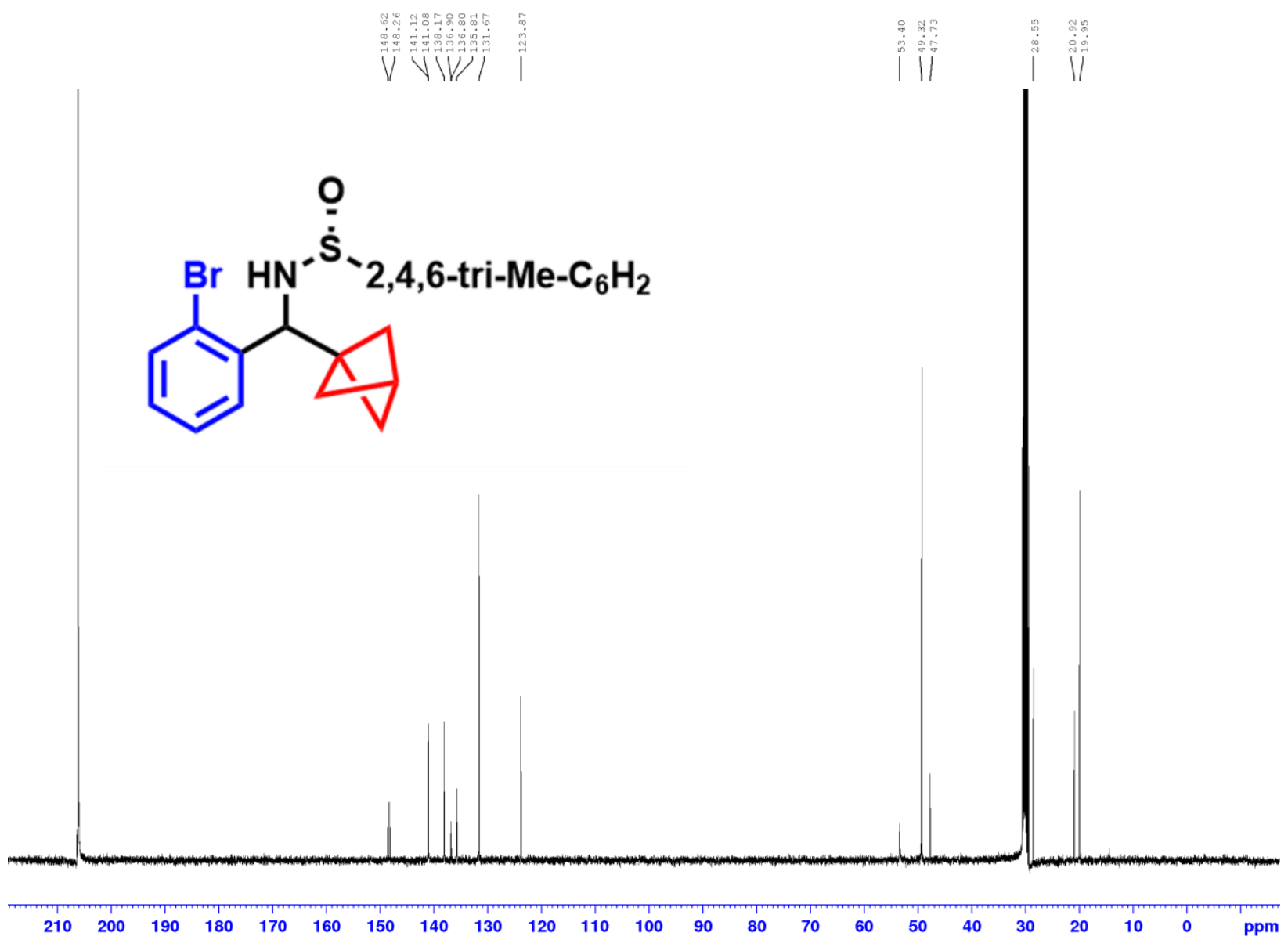


${ }^{1} \mathrm{H}$ NMR spectrum $\left(\mathrm{CDCl}_{3}, 400 \mathrm{MHz}\right)$ of $\mathbf{N}$-(bicyclo[1.1.1]pentan-1-yl(pyridin-2-yl)methyl)-1mesityl-1-( $\boldsymbol{\Lambda}^{\mathbf{1}}$-oxidaneyl)- $\boldsymbol{\Lambda}^{\mathbf{3}}$-sulfanamine $(\mathbf{9 g})$
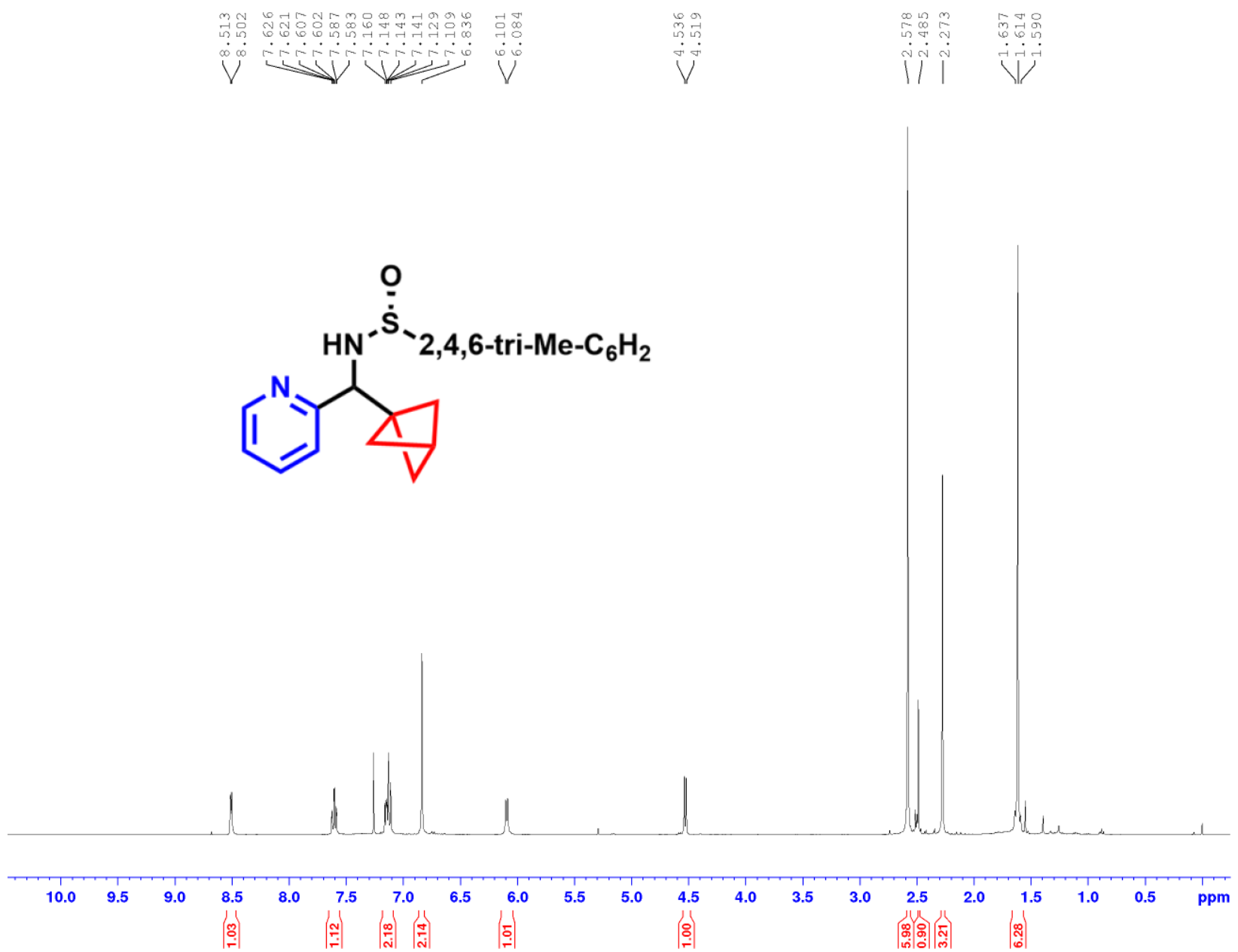
${ }^{13} \mathrm{C}\left\{{ }^{1} \mathrm{H}\right\}$ NMR spectrum $\left(\mathrm{CDCl}_{3}, 100 \mathrm{MHz}\right)$ of $\boldsymbol{N}$-(bicyclo[1.1.1]pentan-1-yl(pyridin-2yl)methyl)-1-mesityl-1-( $\boldsymbol{\kappa}^{\mathbf{1}}$-oxidaneyl)- $\boldsymbol{\kappa}^{\mathbf{3}}$-sulfanamine $(9 \mathrm{~g})$

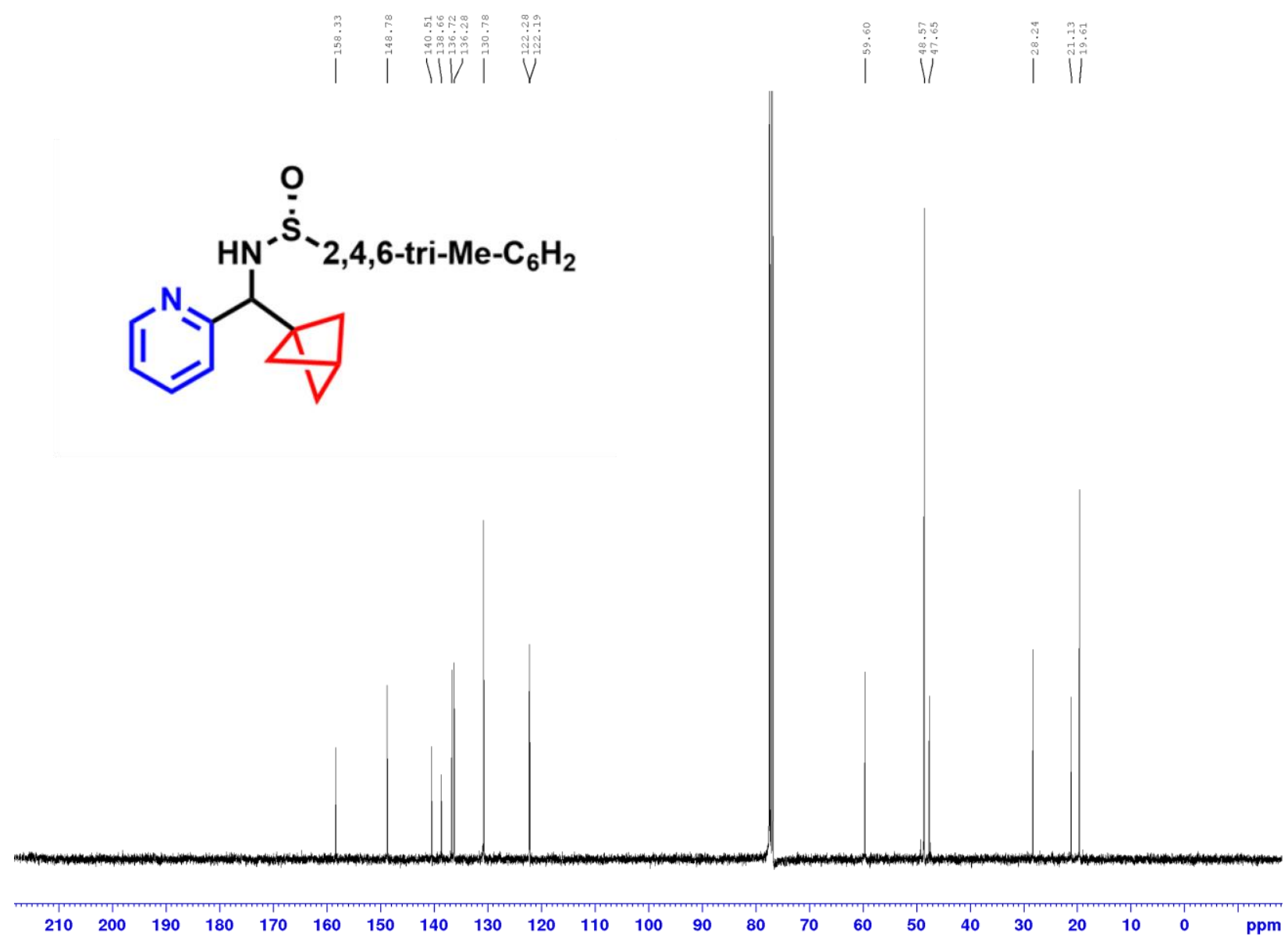


${ }^{1} \mathrm{H}$ NMR spectrum $\left(\mathrm{CDCl}_{3}, 400 \mathrm{MHz}\right)$ of $N$-(bicyclo[1.1.1]pentan-1-yl(pyridin-3-yl)methyl)-1mesityl-1-( $\AA^{1}$-oxidaneyl)- $\hat{\Lambda}^{3}$-sulfanamine $(9 h)$

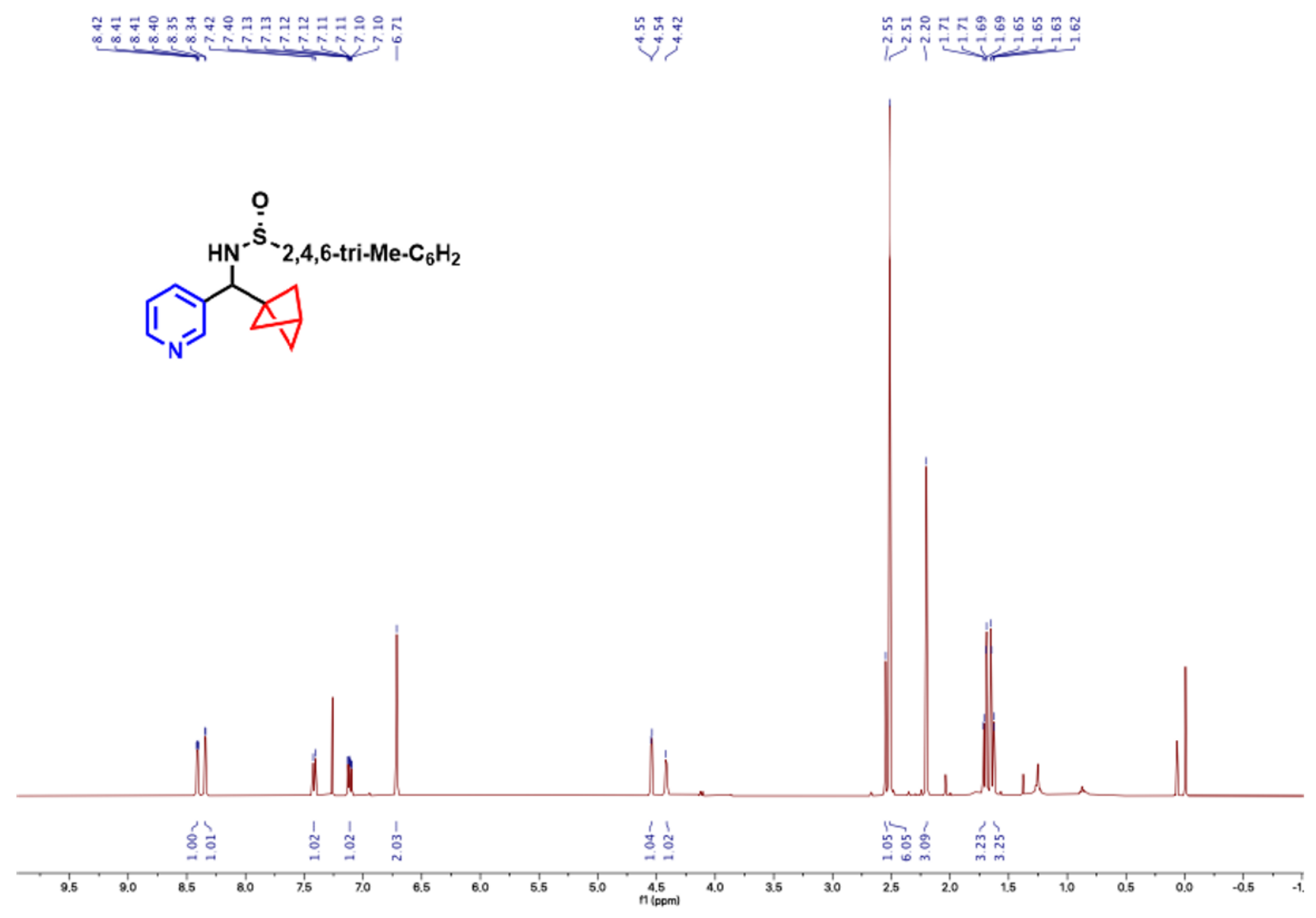


${ }^{13} \mathrm{C}\left\{{ }^{1} \mathrm{H}\right\}$ NMR spectrum $\left(\mathrm{CDCl}_{3}, 100 \mathrm{MHz}\right)$ of $\boldsymbol{N}$-(bicyclo[1.1.1]pentan-1-yl(pyridin-3yl)methyl)-1-mesityl-1-( $\boldsymbol{\kappa}^{\mathbf{1}}$-oxidaneyl)- $\boldsymbol{\kappa}^{\mathbf{3}}$-sulfanamine $(9 \mathrm{~h})$

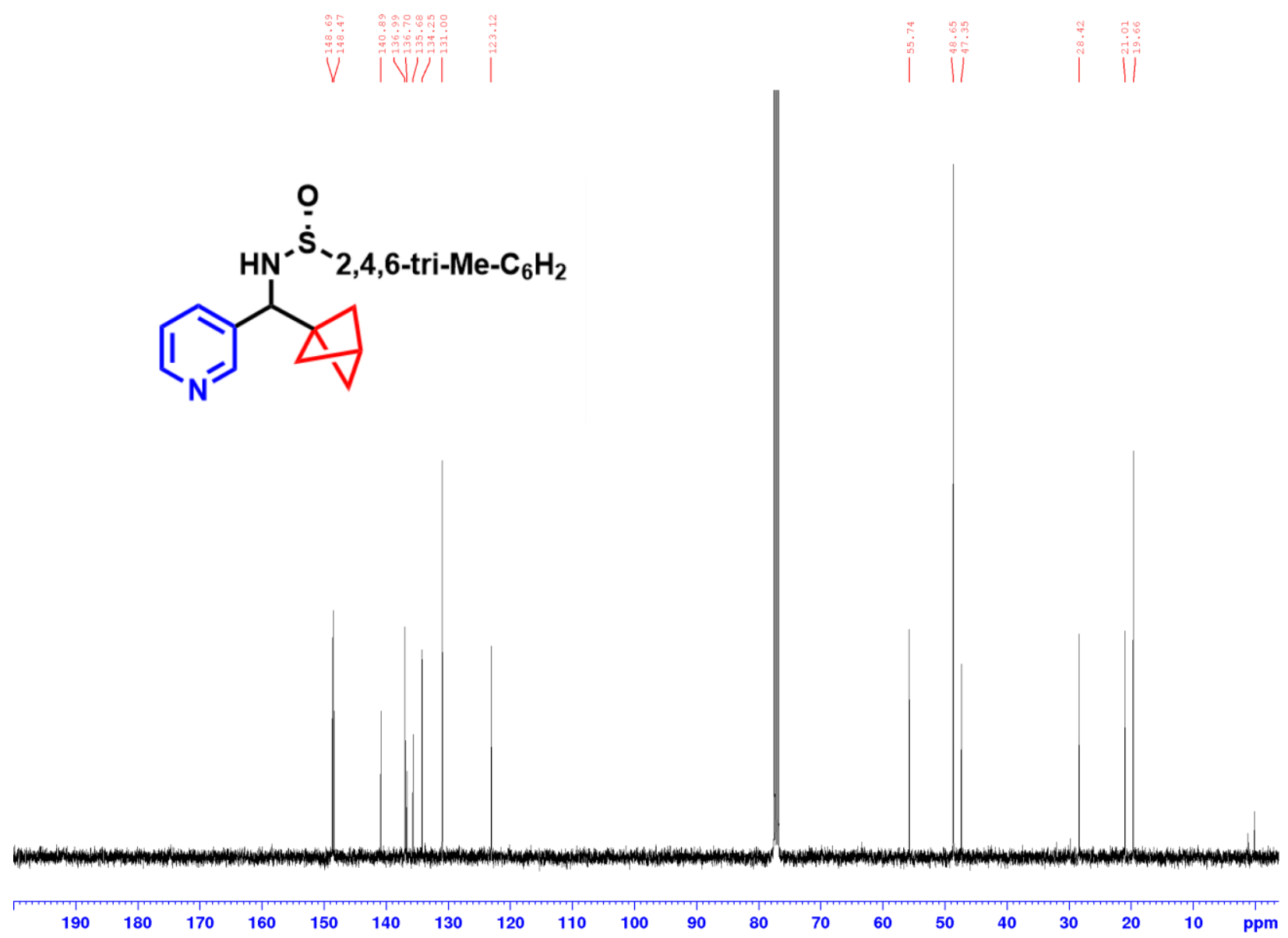


${ }^{1} \mathrm{H}$ NMR spectrum $\left(\left(\mathrm{CD}_{3}\right)_{2} \mathrm{CO}, 400 \mathrm{MHz}\right)$ of $\boldsymbol{N}$-(bicyclo[1.1.1]pentan-1-yl(3-bromopyridin-4yl)methyl)-1-mesityl-1-( $\Lambda^{1}$-oxidaneyl)- $\kappa^{3}$-sulfanamine $(9 \mathrm{i})$

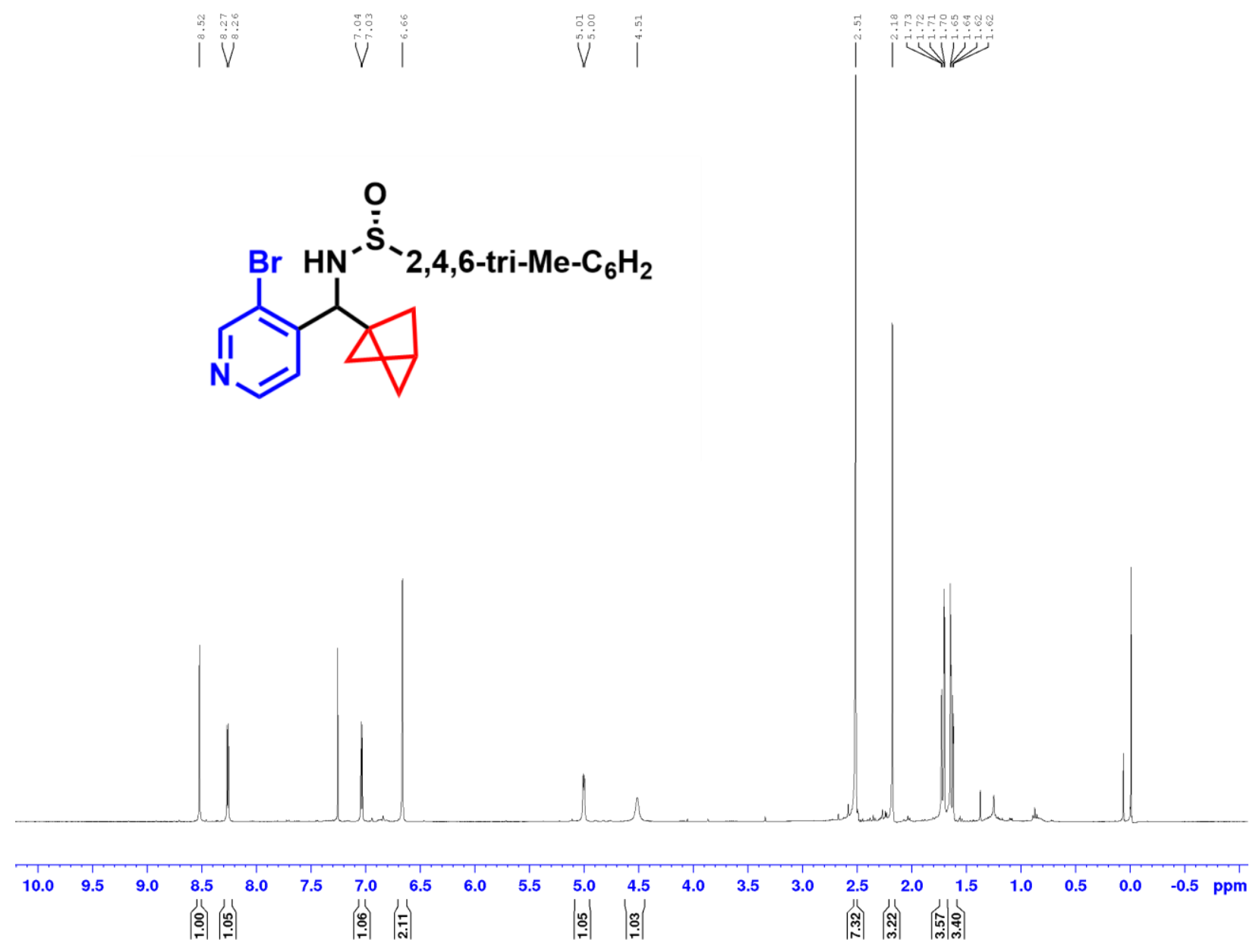


${ }^{13} \mathrm{C}\left\{{ }^{1} \mathrm{H}\right\}$ NMR spectrum $\left(\mathrm{CDCl}_{3}, 100 \mathrm{MHz}\right)$ of $\boldsymbol{N}$-(bicyclo[1.1.1]pentan-1-yl(3-bromopyridin4-yl)methyl)-1-mesityl-1-( $\boldsymbol{\Lambda}^{1}$-oxidaneyl)- $\Lambda^{3}$-sulfanamine (9i)

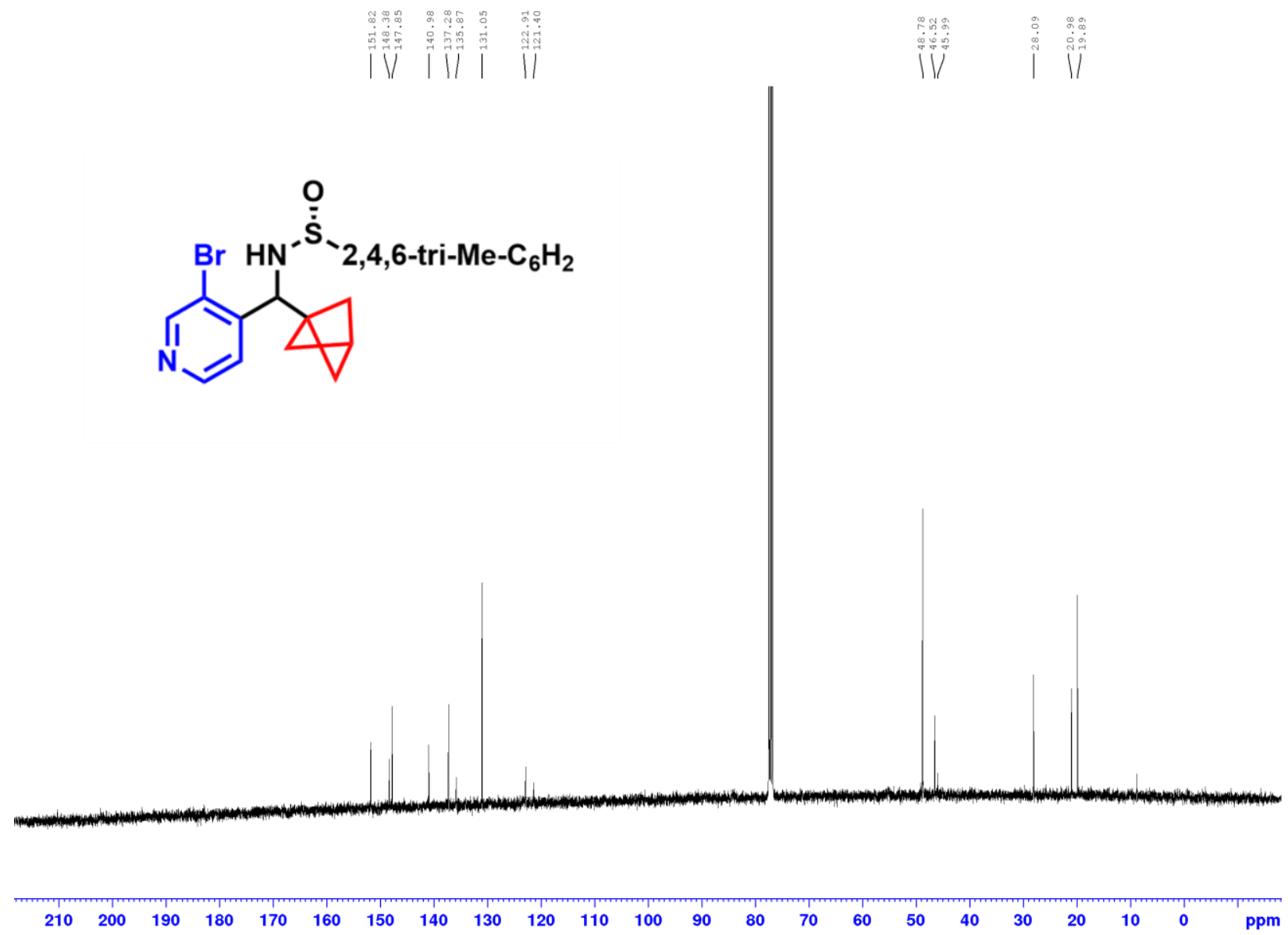


${ }^{1} \mathrm{H}$ NMR spectrum $\left(\mathrm{CDCl}_{3}, 400 \mathrm{MHz}\right)$ of $\boldsymbol{N}$-(bicyclo[1.1.1]pentan-1-yl(2-bromopyridin-4yl)methyl)-1-mesityl-1-( $\boldsymbol{\kappa}^{1}$-oxidaneyl)- $\boldsymbol{\kappa}^{3}$-sulfanamine $(9 \mathrm{j})$

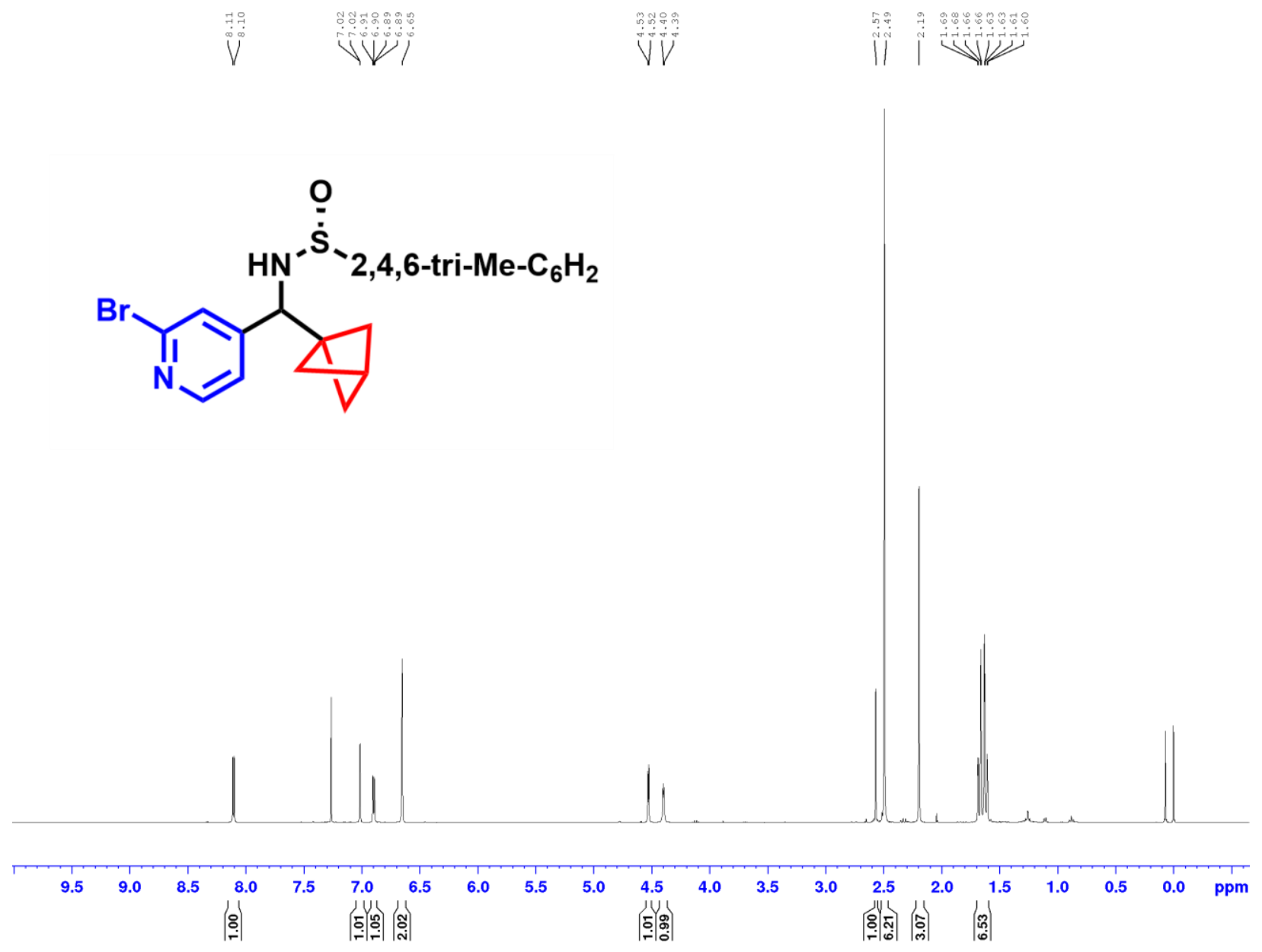


${ }^{13} \mathrm{C}\left\{{ }^{1} \mathrm{H}\right\}$ NMR spectrum $\left(\mathrm{CDCl}_{3}, 100 \mathrm{MHz}\right)$ of $N$-(bicyclo[1.1.1]pentan-1-yl(2-bromopyridin4-yl)methyl)-1-mesityl-1-( $\AA^{\mathbf{1}}$-oxidaneyl)- $\boldsymbol{\Lambda}^{\mathbf{3}}$-sulfanamine $(9 \mathrm{j})$

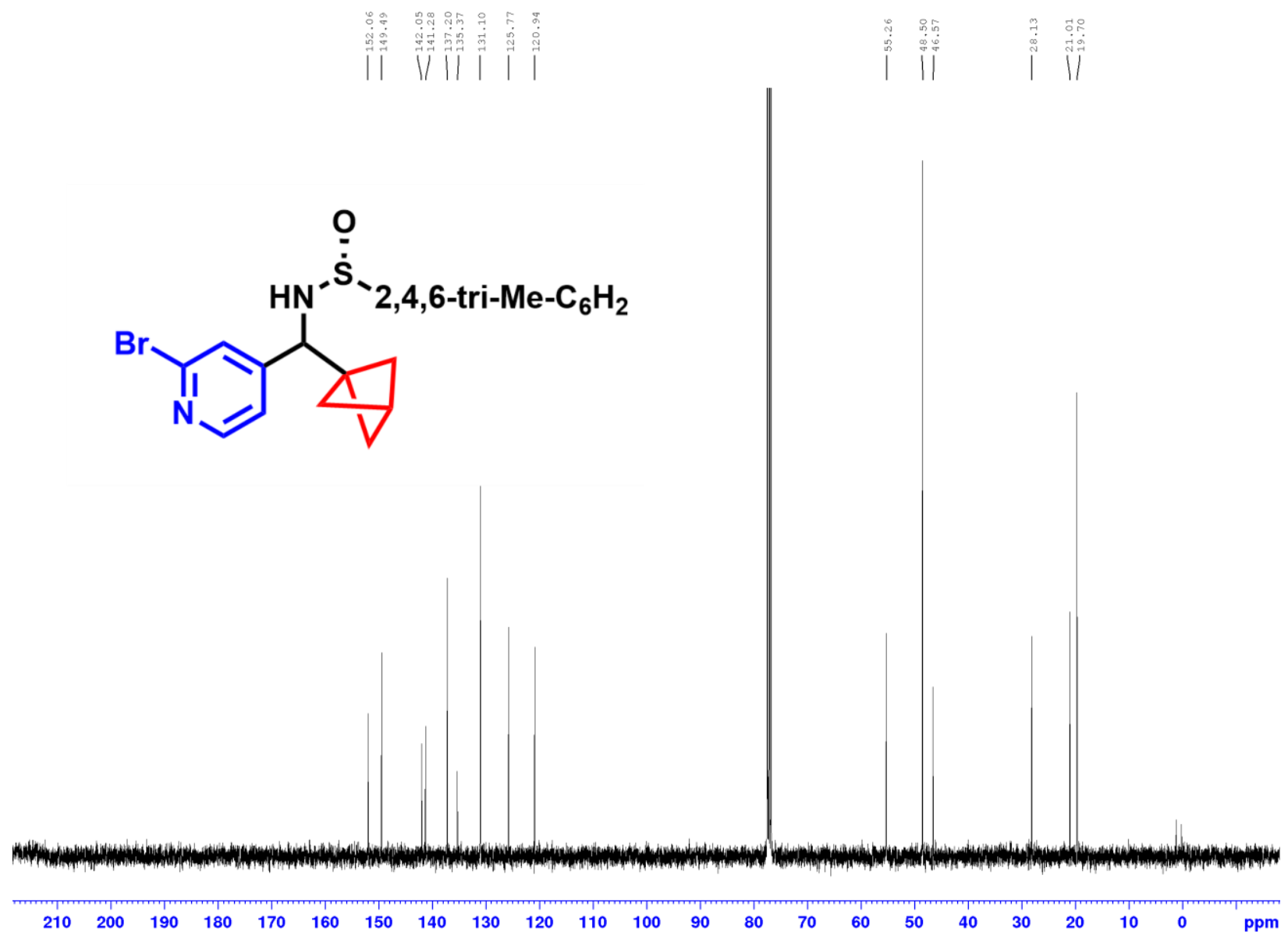


${ }^{1} \mathrm{H}$ NMR spectrum $\left(\mathrm{CDCl}_{3}, 400 \mathrm{MHz}\right)$ of $\boldsymbol{N}$-(bicyclo[1.1.1]pentan-1-yl(6-bromopyridin-2yl)methyl)-1-mesityl-1-( $\boldsymbol{\Lambda}^{1}$-oxidaneyl)- $\kappa^{3}$-sulfanamine $(9 \mathrm{k})$

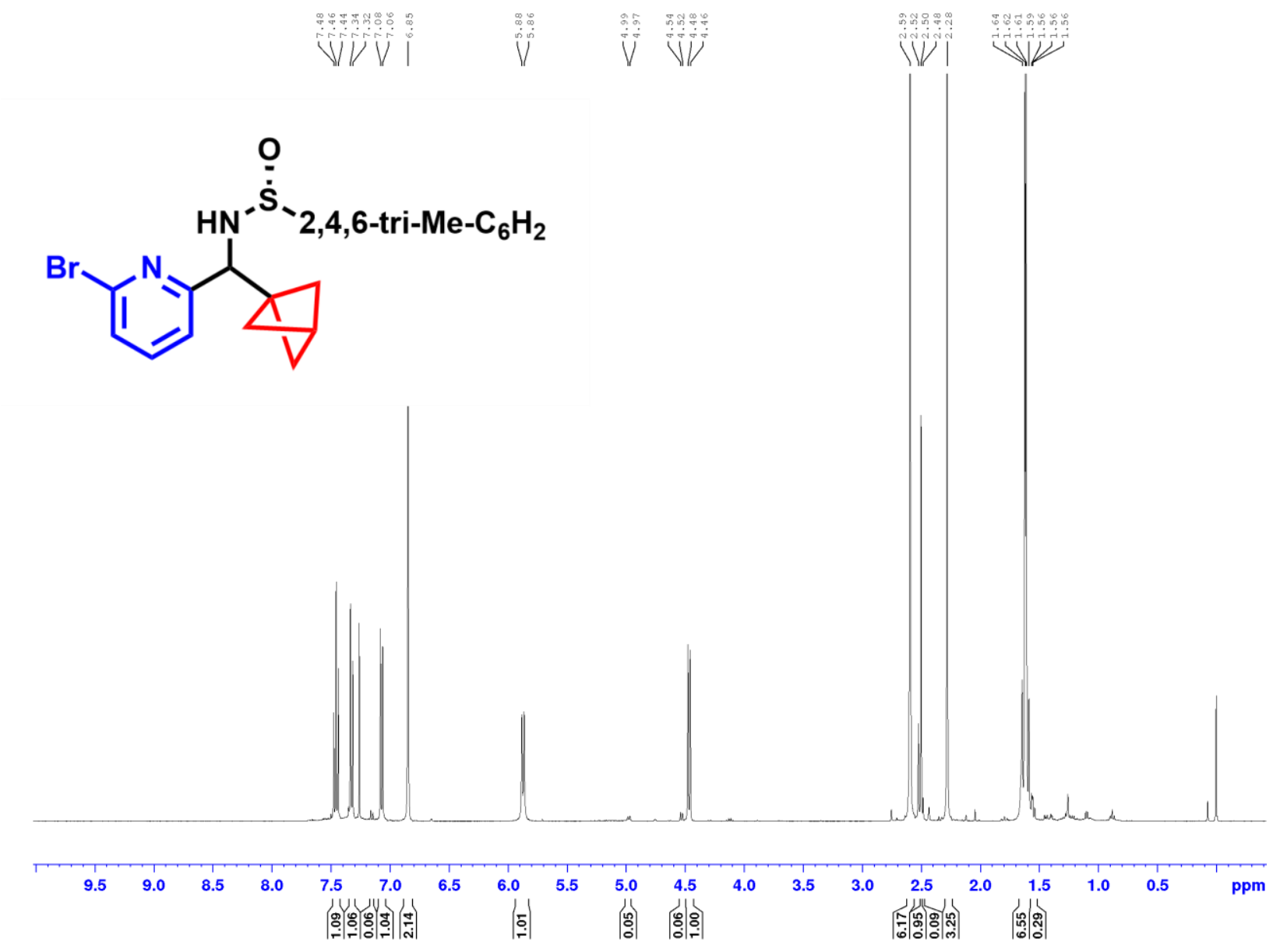


${ }^{13} \mathrm{C}\left\{{ }^{1} \mathrm{H}\right\}$ NMR spectrum $\left(\mathrm{CDCl}_{3}, 100 \mathrm{MHz}\right)$ of $\boldsymbol{N}$-(bicyclo[1.1.1]pentan-1-yl(6-bromopyridin2-yl)methyl)-1-mesityl-1-( $\hat{\Lambda}^{\mathbf{1}}$-oxidaneyl)- $\boldsymbol{\Lambda}^{\mathbf{3}}$-sulfanamine $(9 \mathrm{k})$

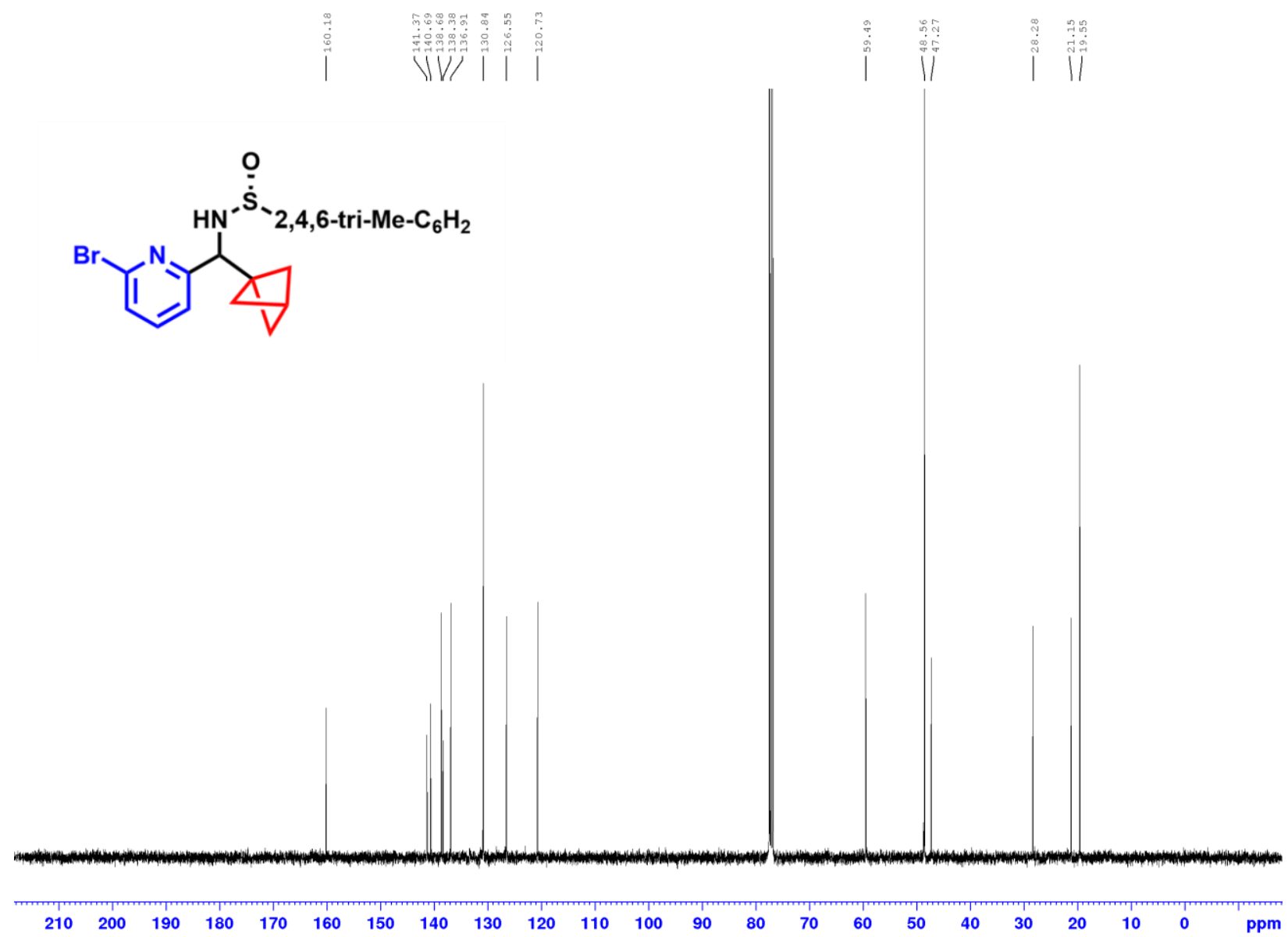


${ }^{1} \mathrm{H}$ NMR spectrum $\left(\mathrm{CDCl}_{3}, 400 \mathrm{MHz}\right)$ of $\boldsymbol{N}$-(bicyclo[1.1.1]pentan-1-yl(6-methoxypyridin-2yl)methyl)-1-mesityl-1-( $\boldsymbol{K}^{1}$-oxidaneyl)- $\hat{K}^{3}$-sulfanamine (9l)

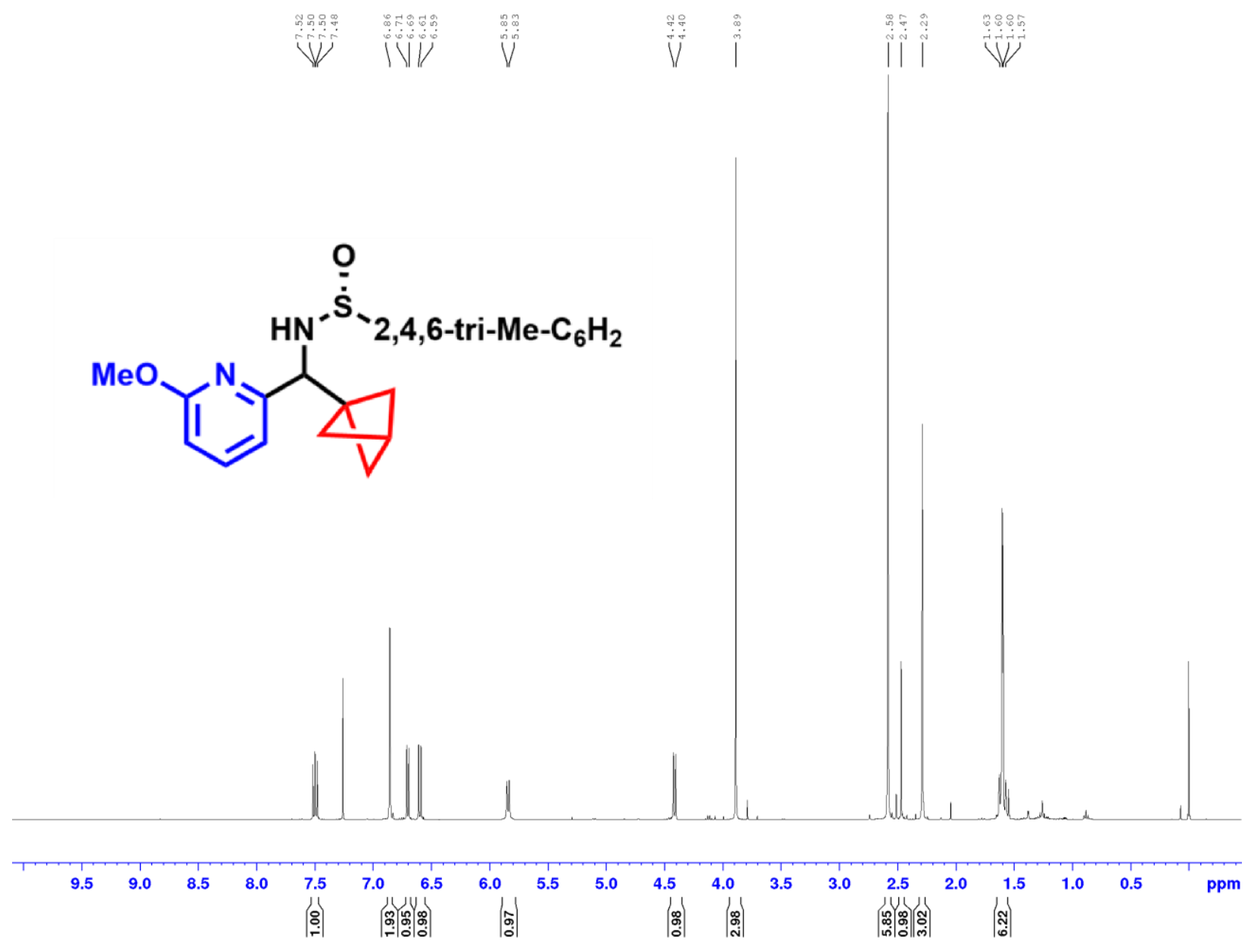


${ }^{13} \mathrm{C}\left\{{ }^{1} \mathrm{H}\right\}$ NMR spectrum $\left(\mathrm{CDCl}_{3}, 100 \mathrm{MHz}\right)$ of $N$-(bicyclo[1.1.1]pentan-1-yl(6methoxypyridin-2-yl)methyl)-1-mesityl-1-( $\boldsymbol{\Lambda}^{1}$-oxidaneyl)- $\boldsymbol{\Lambda}^{3}$-sulfanamine $(9 \mathrm{I})$

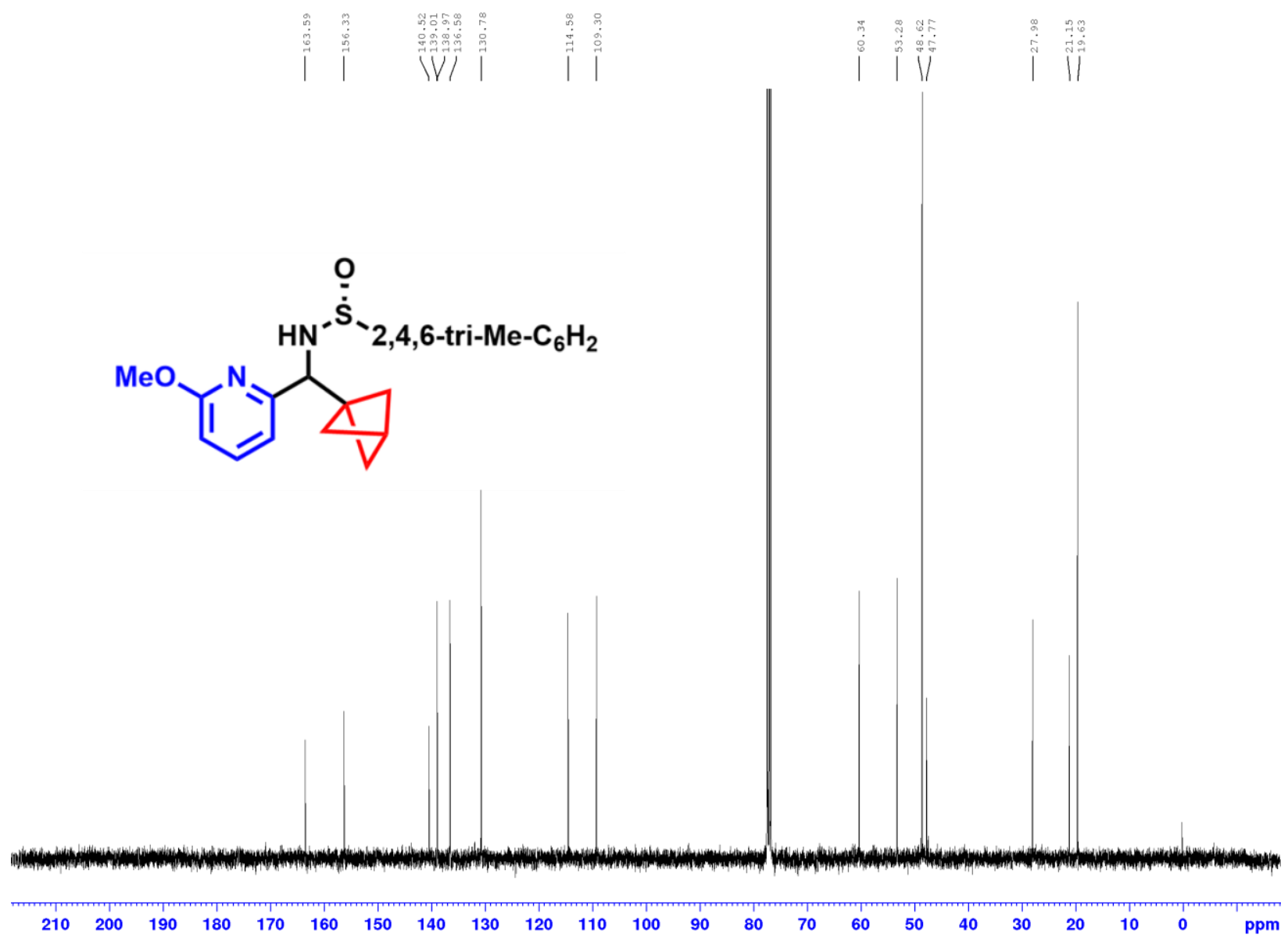


${ }^{1} \mathrm{H}$ NMR spectrum $\left(\mathrm{CDCl}_{3}, 400 \mathrm{MHz}\right)$ of $\boldsymbol{N}$-(bicyclo[1.1.1]pentan-1-yl(2,6-dichloropyridin-3yl)methyl)-1-mesityl-1-( $\boldsymbol{\Lambda}^{1}$-oxidaneyl)- $\boldsymbol{\Lambda}^{3}$-sulfanamine $(9 \mathrm{~m})$

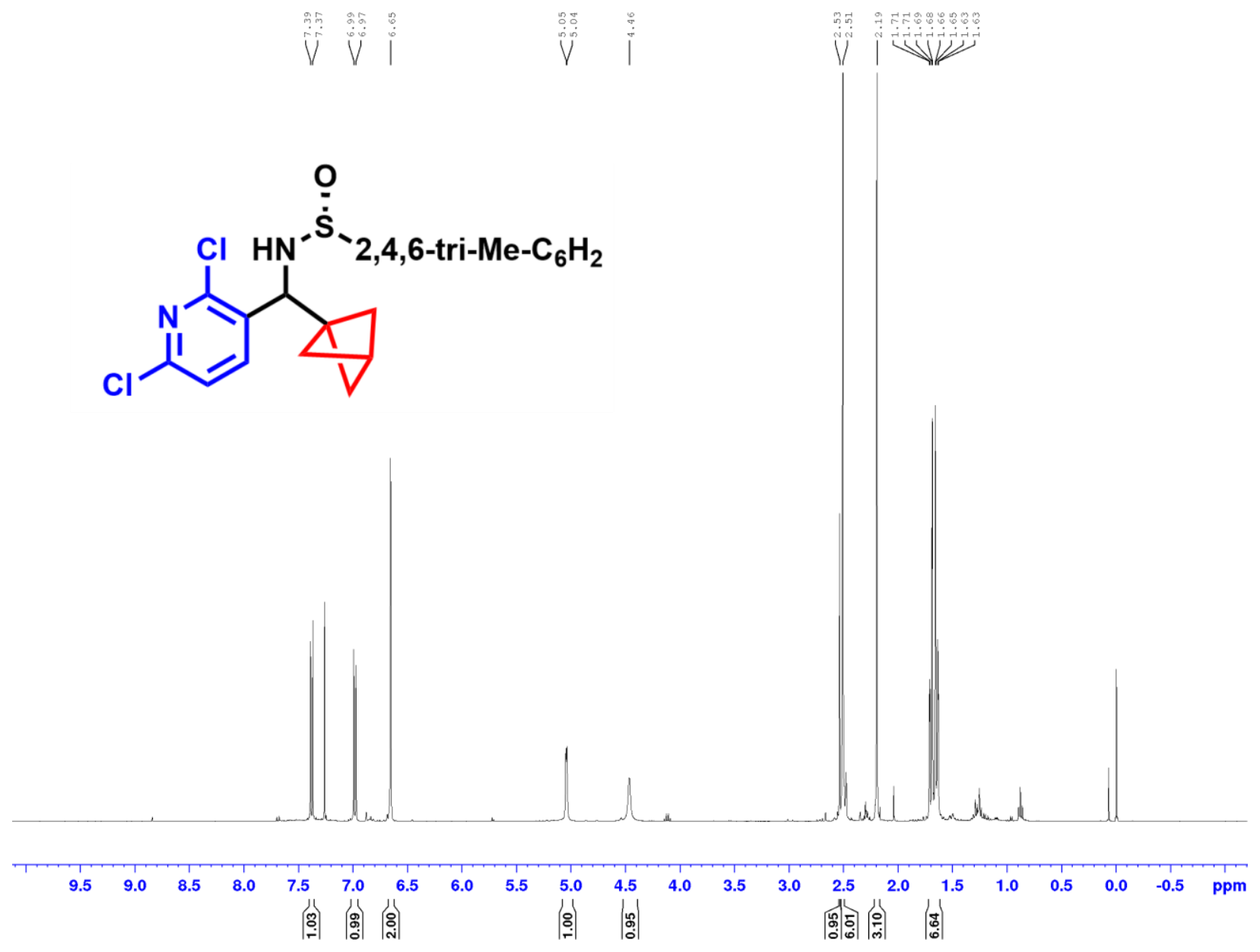


${ }^{13} \mathrm{C}\left\{{ }^{1} \mathrm{H}\right\}$ NMR spectrum $\left(\left(\mathrm{CDCl}_{3}, 100 \mathrm{MHz}\right)\right.$ of $\mathbf{N}$-(bicyclo[1.1.1]pentan-1-yl(2,6dichloropyridin-3-yl)methyl)-1-mesityl-1-( $\Lambda^{1}$-oxidaneyl)- $\kappa^{3}$-sulfanamine $(9 \mathrm{~m})$

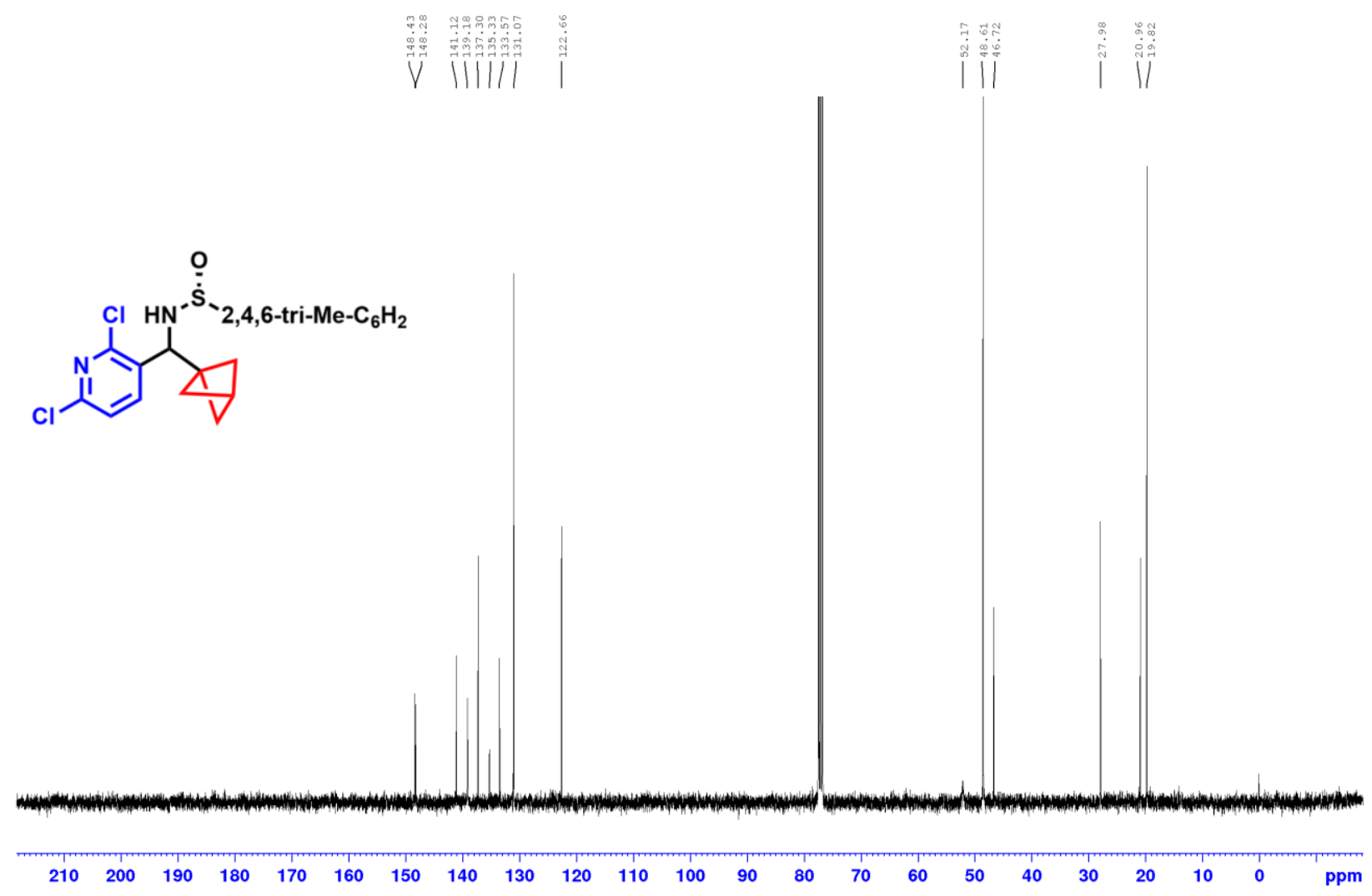


${ }^{1} \mathrm{H}$ NMR spectrum $\left(\mathrm{CDCl}_{3}, 400 \mathrm{MHz}\right)$ of $N$-(bicyclo[1.1.1]pentan-1-yl(4methoxyphenyl)methyl)-1-mesityl-1-( $\kappa^{1}$-oxidaneyl)- $\kappa^{3}$-sulfanamine (9n)

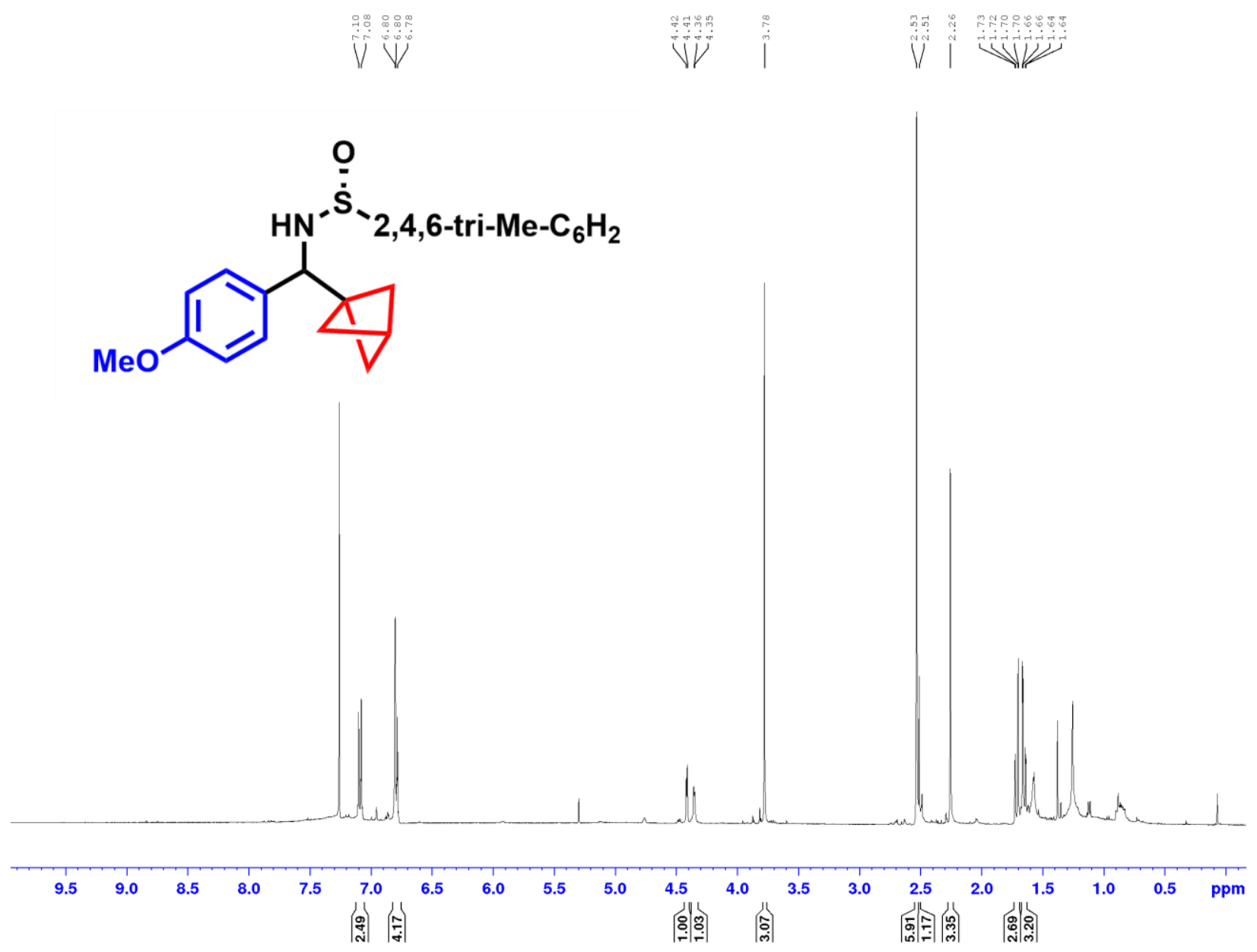


${ }^{13} \mathrm{C}\left\{{ }^{1} \mathrm{H}\right\}$ NMR spectrum $\left(\mathrm{CDCl}_{3}, 100 \mathrm{MHz}\right)$ of $N$-(bicyclo[1.1.1]pentan-1-yl(4methoxyphenyl)methyl)-1-mesityl-1-( $\hat{\Lambda}^{1}$-oxidaneyl)- $\kappa^{3}$-sulfanamine $(9 \mathrm{n})$<smiles></smiles>
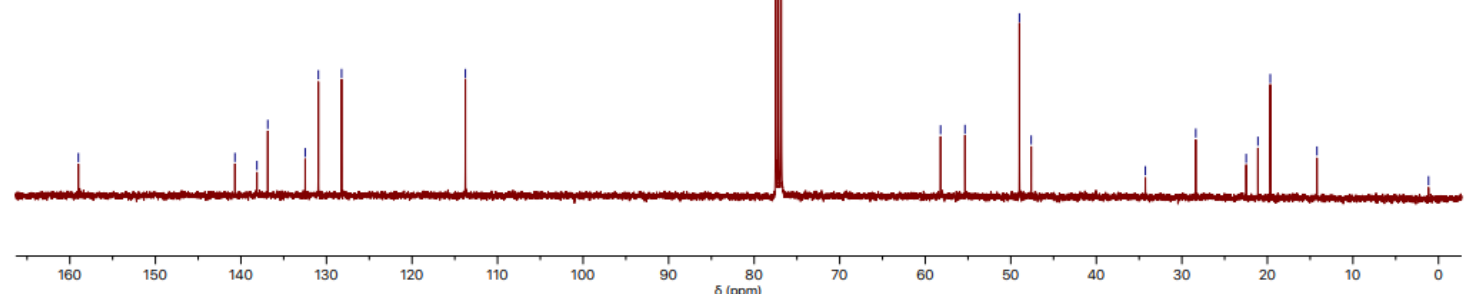
${ }^{1} \mathrm{H}$ NMR spectrum $\left(\left(\mathrm{CD}_{3}\right)_{2} \mathrm{CO}, 400 \mathrm{MHz}\right)$ of 2-(bicyclo[1.1.1]pentan-1-yl((mesityl( $\boldsymbol{\lambda}^{\mathbf{1}}$ oxidaneyl)- $\lambda^{3}$-sulfaneyl)amino)methyl)phenethyl benzoate (90)

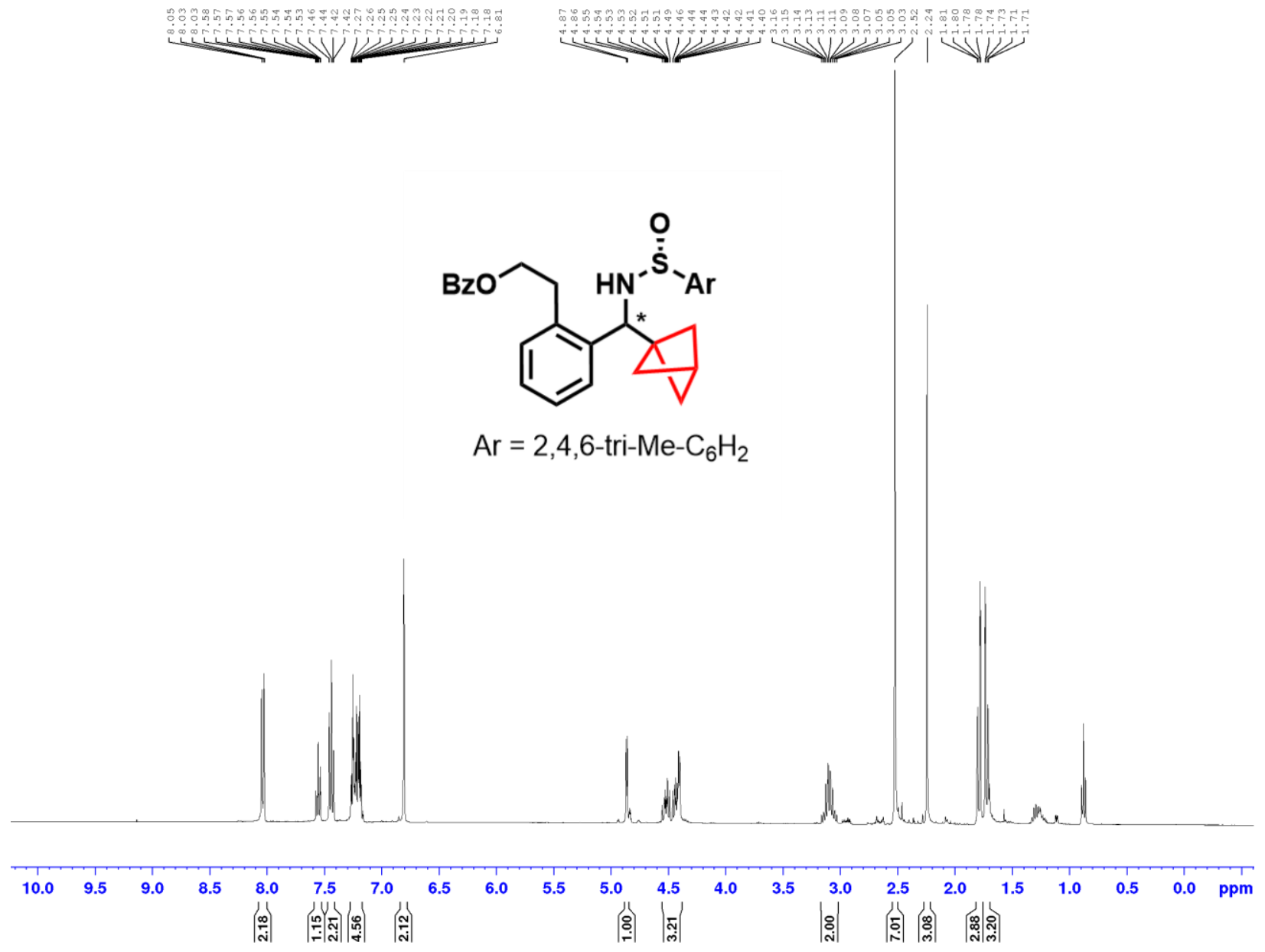


${ }^{13} \mathrm{C}\left\{{ }^{1} \mathrm{H}\right\}$ NMR spectrum $\left(\mathrm{CDCl}_{3}, 100 \mathrm{MHz}\right)$ of 2-(bicyclo[1.1.1]pentan-1-yl $\left(\left(\right.\right.$ mesityl $\left(\lambda^{\mathbf{1}}\right.$ oxidaneyl)- $\lambda^{3}$-sulfaneyl)amino)methyl)phenethyl benzoate (90)
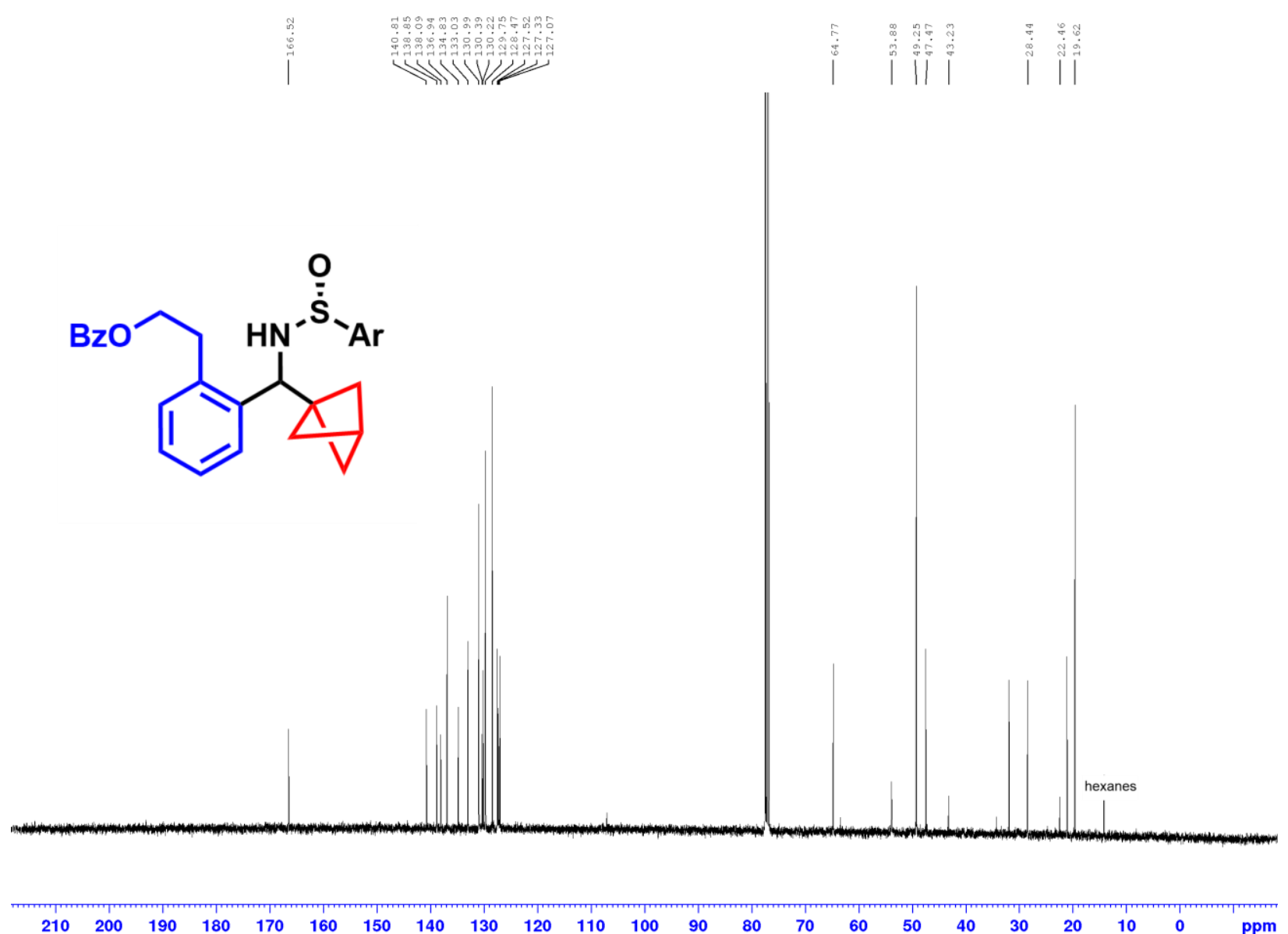
COSY spectrum $\left(\left(\mathrm{CD}_{3}\right)_{2} \mathrm{CO}, 400 \mathrm{MHz}\right)$ of 2-(bicyclo[1.1.1]pentan-1-yl((mesityl( $\lambda^{\mathbf{1}}$-oxidaneyl)$\lambda^{3}$-sulfaneyl)amino)methyl)phenethyl benzoate (90)

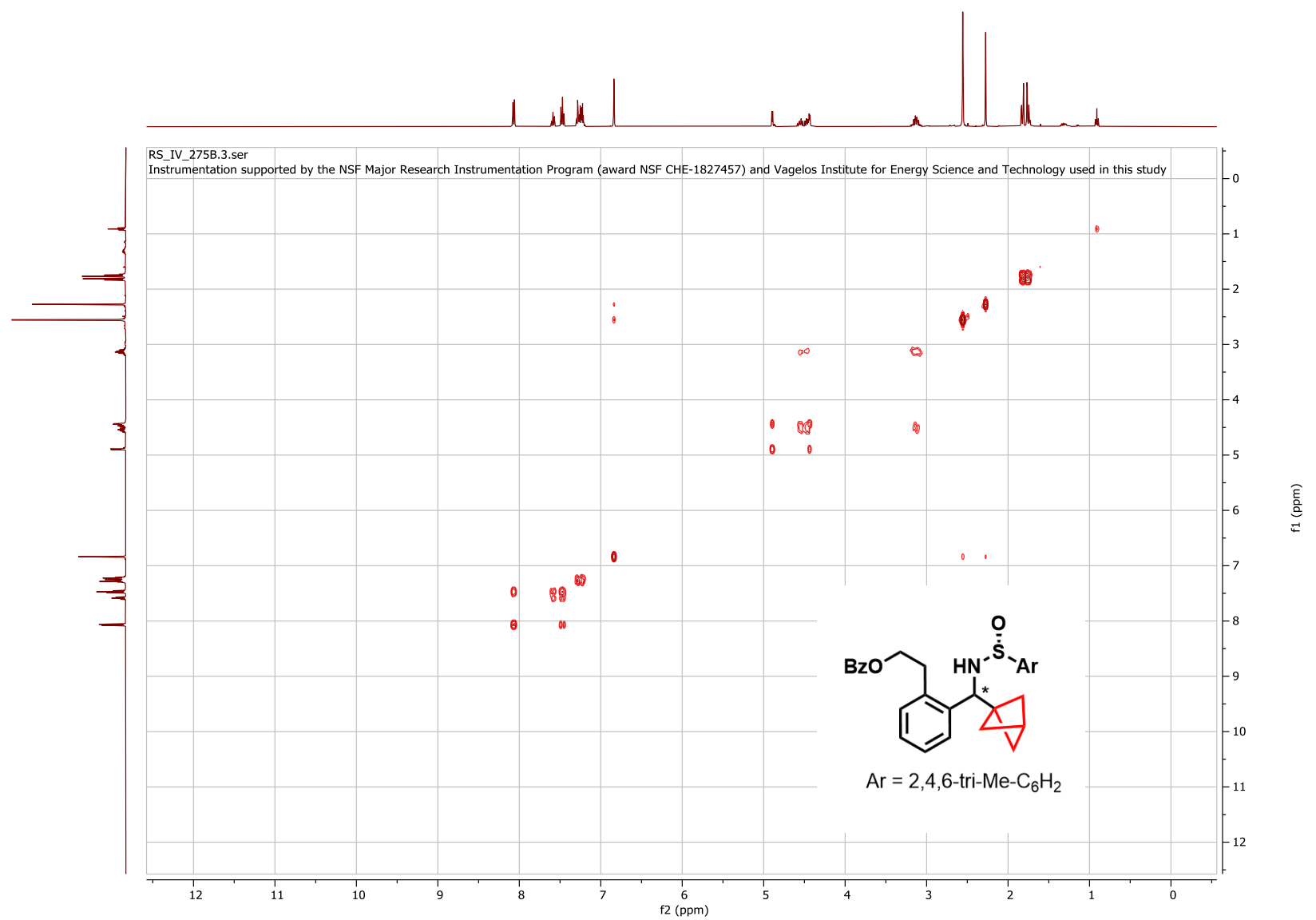


${ }^{1} \mathrm{H}$ NMR spectrum $\left(\left(\mathrm{CDCl}_{3}, 400 \mathrm{MHz}\right)\right.$ of bicyclo[1.1.1]pentan-1-yl(4chlorophenyl)methanamine

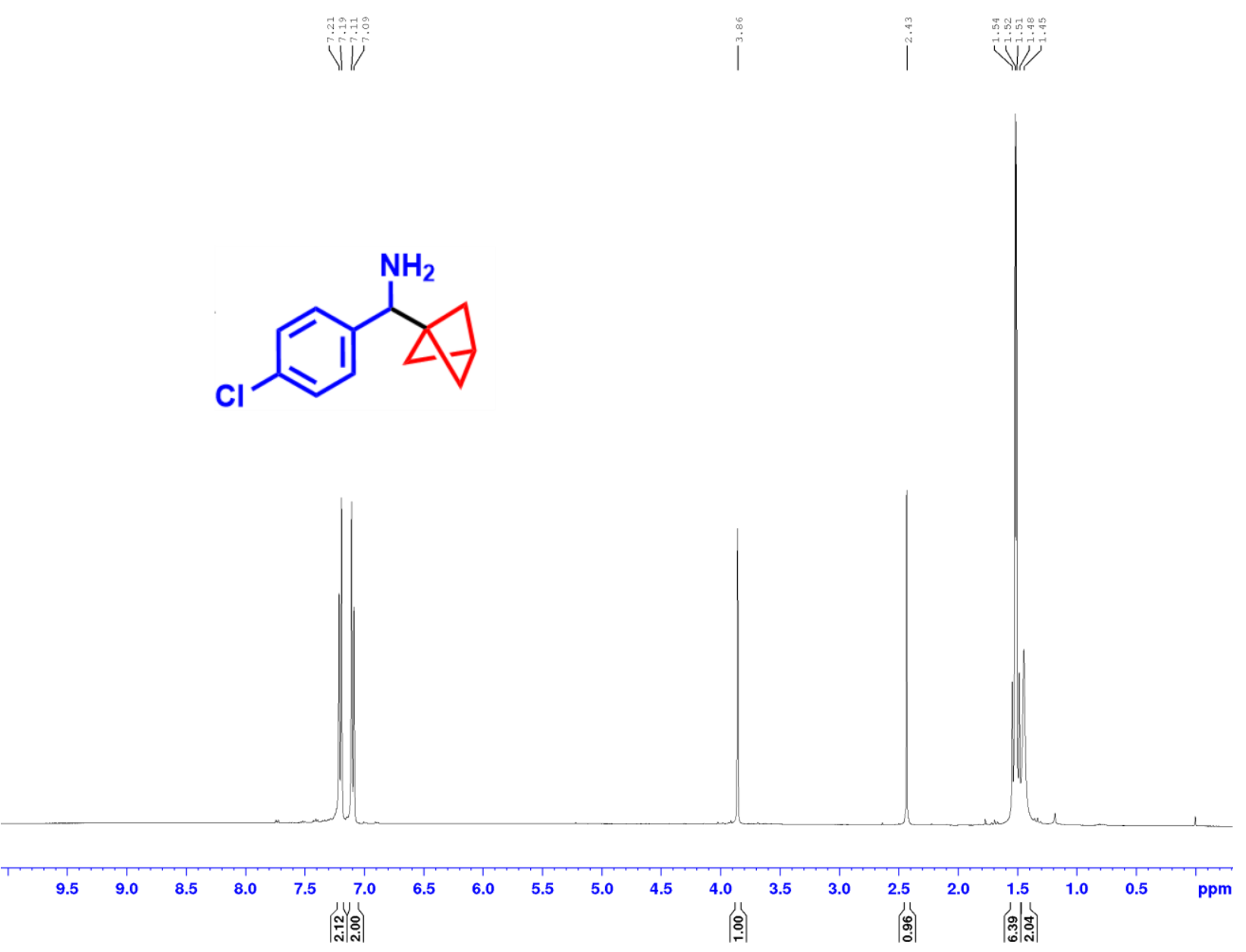


${ }^{13} \mathrm{C}\left\{{ }^{1} \mathrm{H}\right\}$ NMR spectrum $\left(\mathrm{CDCl}_{3}, 100 \mathrm{MHz}\right)$ of bicyclo[1.1.1]pentan-1-yl(4chlorophenyl)methanamine

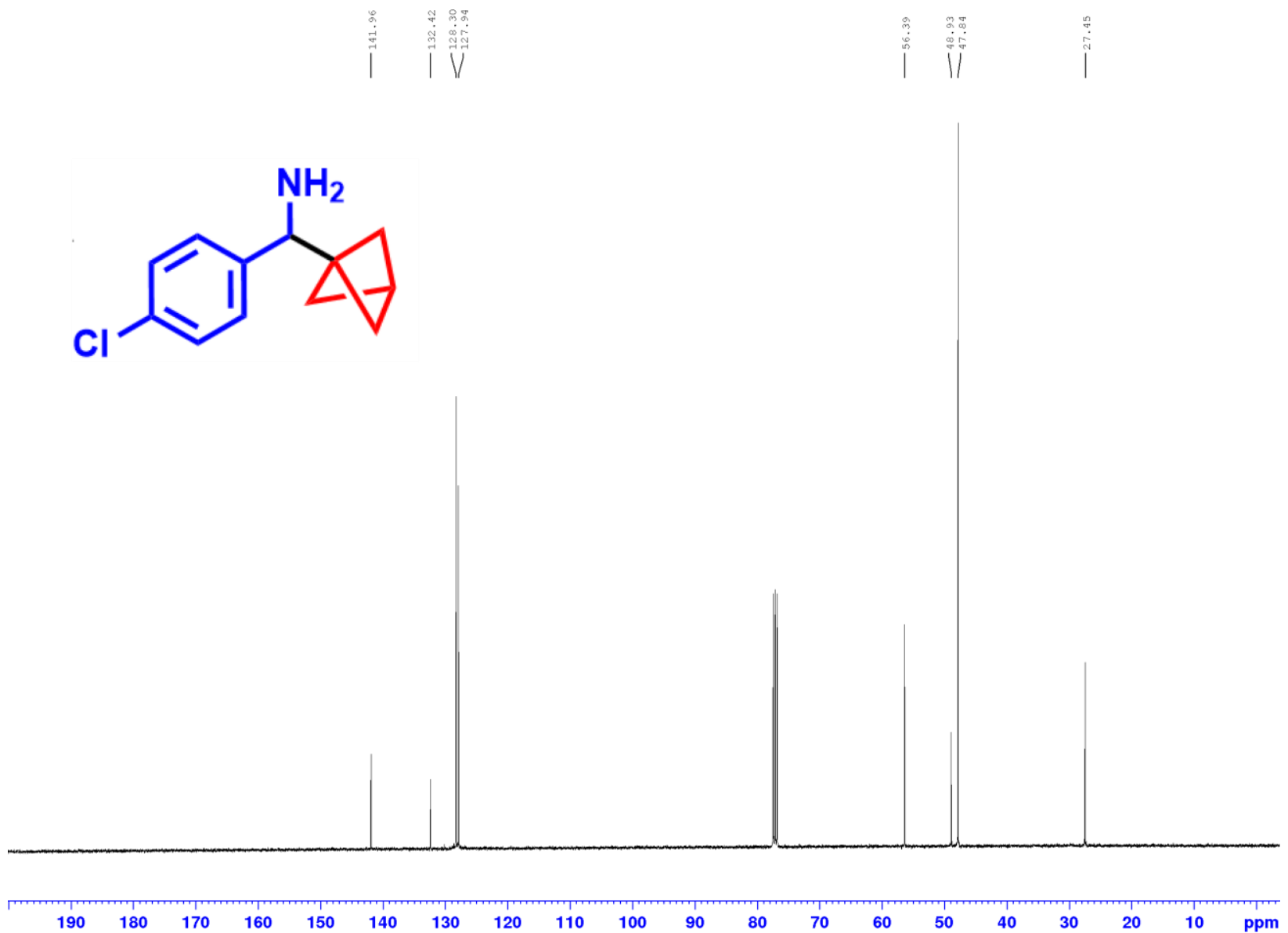


${ }^{1} \mathrm{H}$ NMR spectrum $\left(\left(\mathrm{CDCl}_{3}, 400 \mathrm{MHz}\right)\right.$ of bicyclo[1.1.1]pentan-1-yl(pyridin-3yl)methanamine (14a)

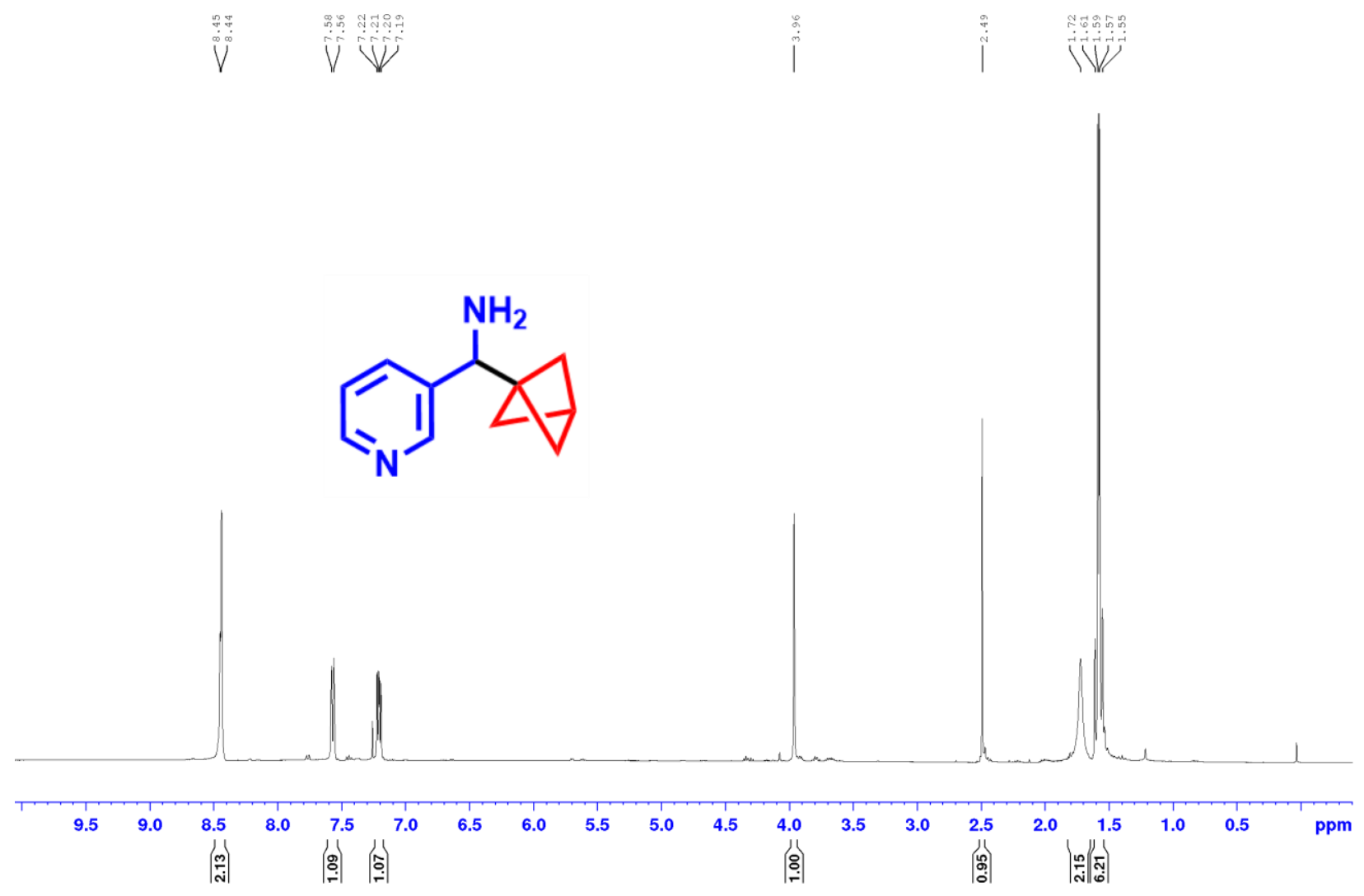


${ }^{13} \mathrm{C}\left\{{ }^{1} \mathrm{H}\right\}$ NMR spectrum $\left(\mathrm{CDCl}_{3}, 100 \mathrm{MHz}\right)$ of bicyclo[1.1.1]pentan-1-yl(pyridin-3yl)methanamine (14a)

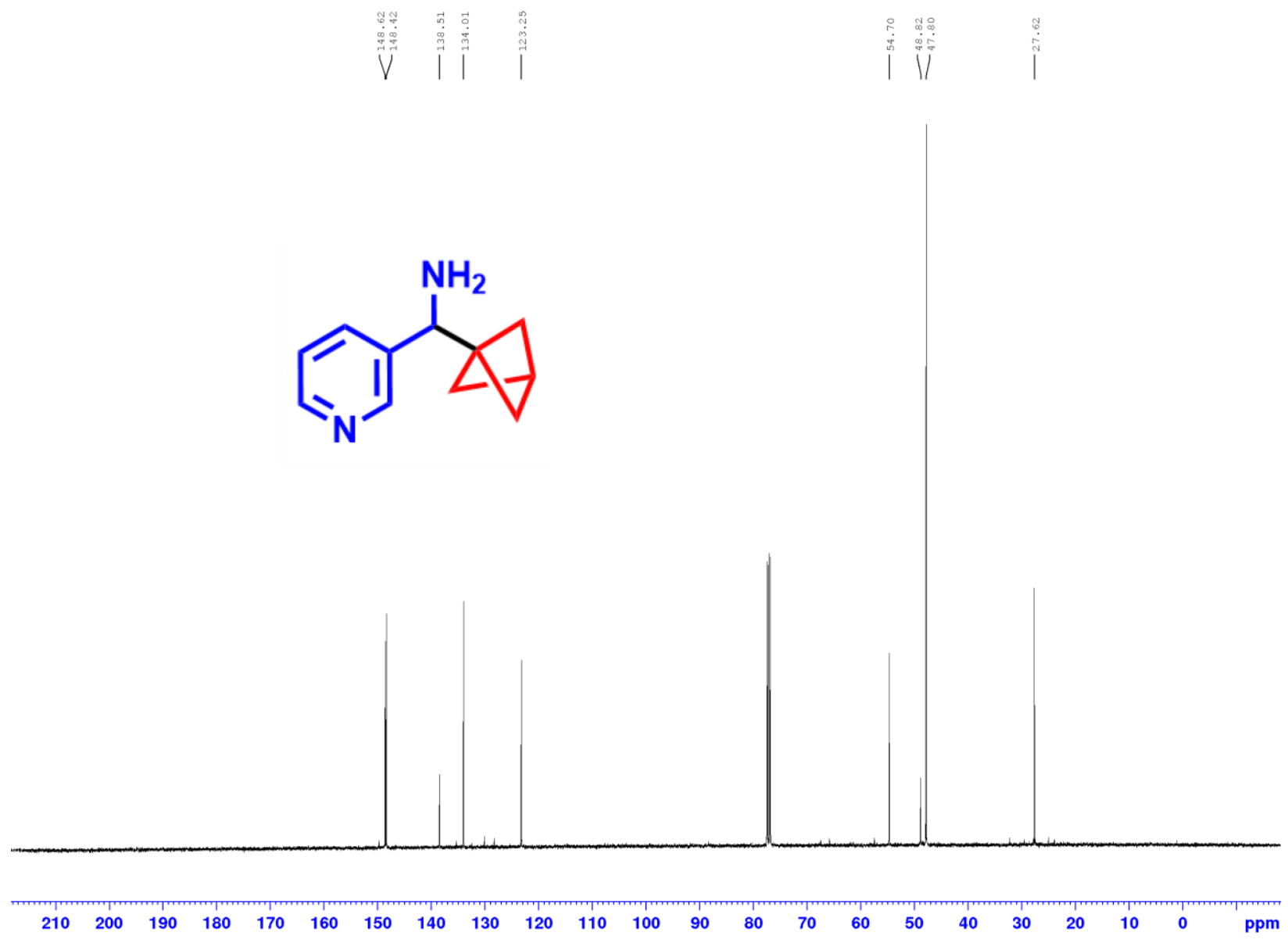


${ }^{1} \mathrm{H}$ NMR spectrum $\left(\left(\mathrm{CD}_{3}\right)_{2} \mathrm{CO}, 400 \mathrm{MHz}\right)$ of 1-(bicyclo[1.1.1]pentan-1-yl(4chlorophenyl)methyl)-4-tosylpiperazine (15)

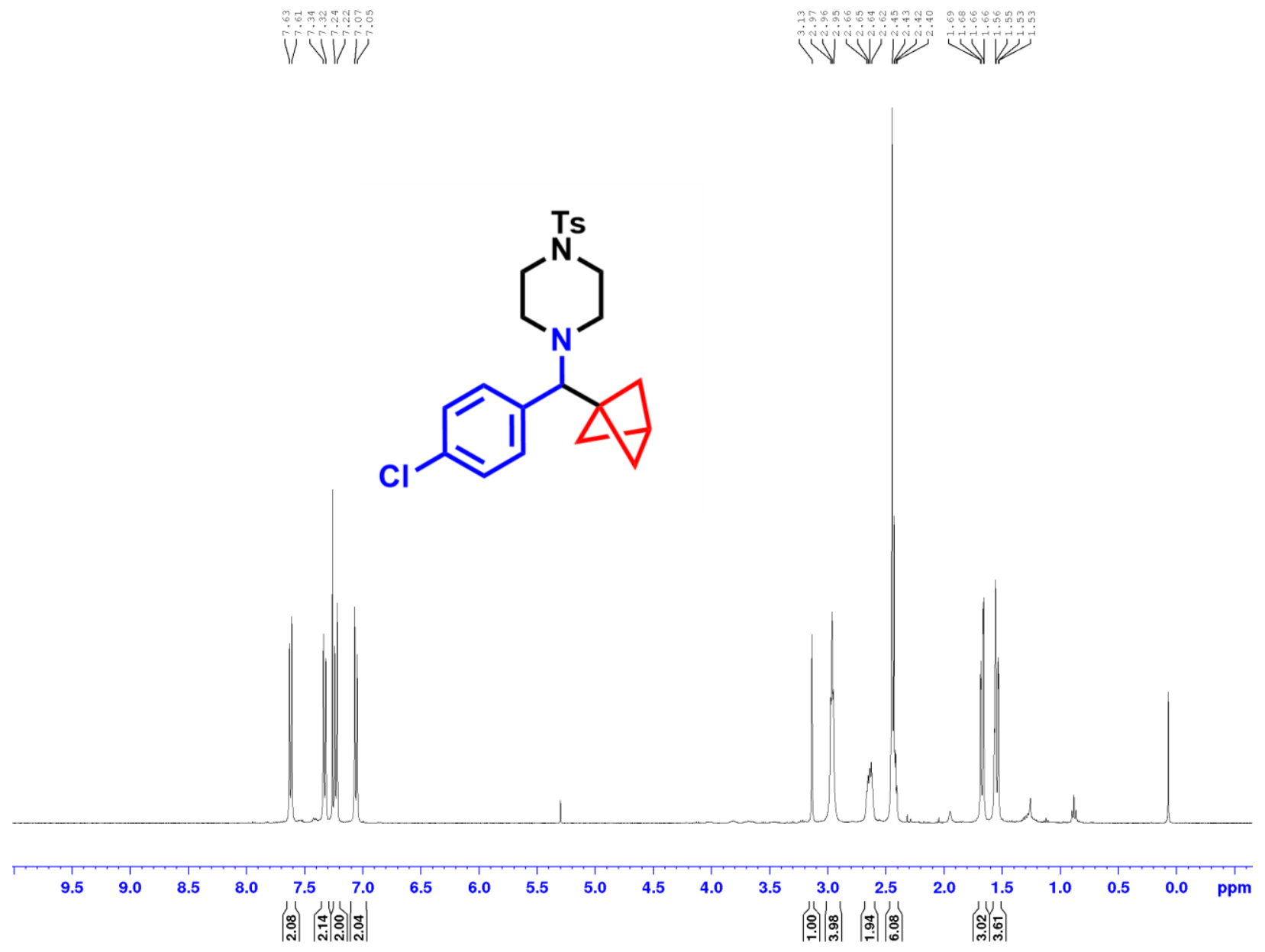


${ }^{13} \mathrm{C}\left\{{ }^{1} \mathrm{H}\right\}$ NMR spectrum $\left(\mathrm{CDCl}_{3}, 100 \mathrm{MHz}\right)$ of 1-(bicyclo[1.1.1]pentan-1-yl(4chlorophenyl)methyl)-4-tosylpiperazine (15)

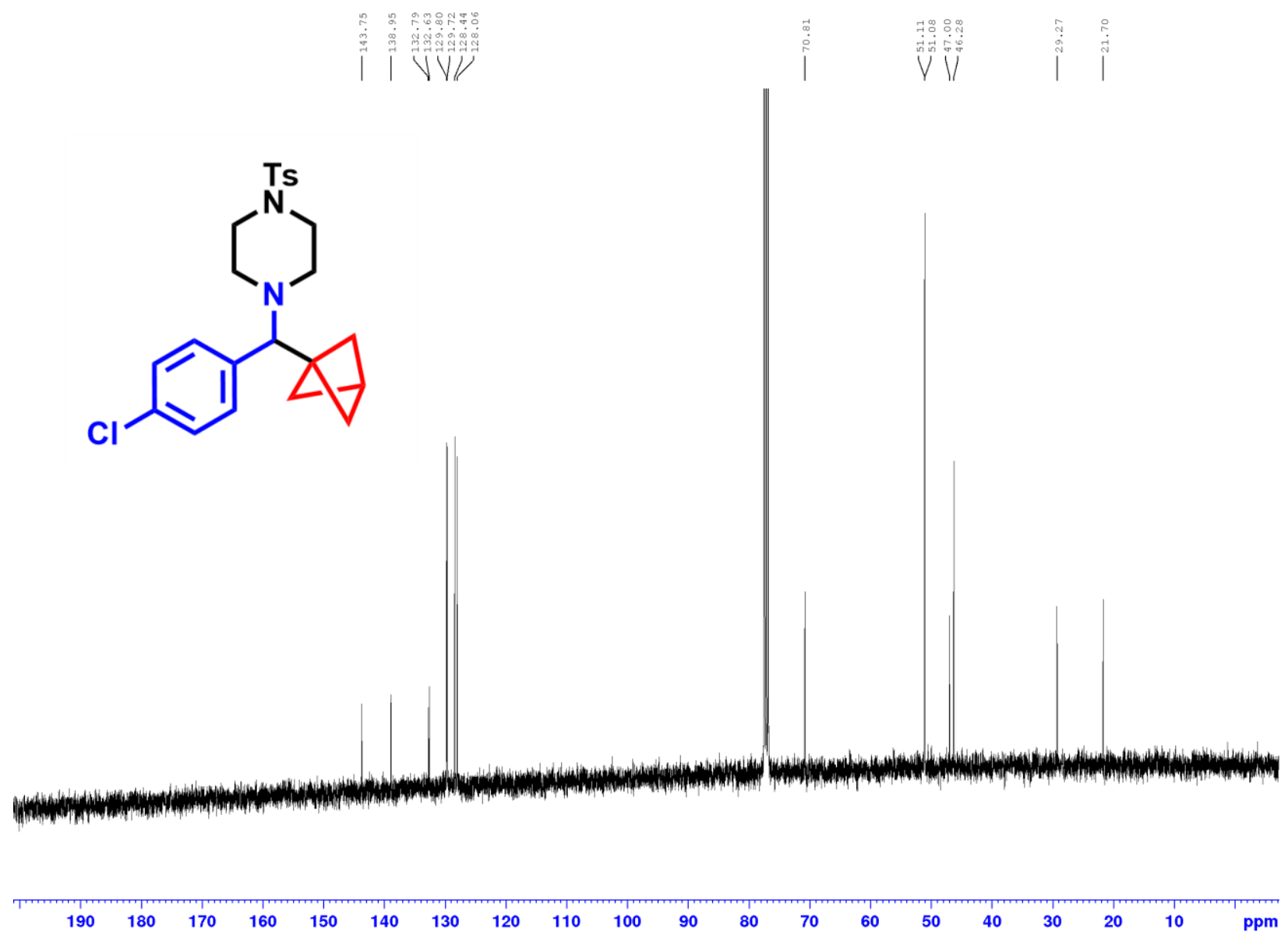

